\title{
The Unintended Consequences of Democracy Promotion: International Organizations and Democratic Backsliding
}

\author{
Dissertation \\ Presented in Partial Fulfillment of the Requirements for the Degree \\ Doctor of Philosophy in the Graduate School of The Ohio State \\ University \\ By \\ Anna M. Meyerrose, M.A. \\ Graduate Program in Political Science
}

The Ohio State University

2019

Dissertation Committee:

Alexander Thompson, Co-Advisor

Irfan Nooruddin, Co-Advisor

Marcus Kurtz

William Minozzi

Sara Watson 
(c) Copyright by

Anna M. Meyerrose

2019 


\begin{abstract}
Since the end of the Cold War, international organizations (IOs) have engaged in unprecedented levels of democracy promotion and are widely viewed as positive forces for democracy. However, this increased emphasis on democracy has more recently been accompanied by rampant illiberalism and a sharp rise in cases of democratic backsliding in new democracies. What explains democratic backsliding in an age of unparalleled international support for democracy? Democratic backsliding occurs when elected officials weaken or erode democratic institutions and results in an illiberal or diminished form of democracy, rather than autocracy. This dissertation argues that IOs commonly associated with democracy promotion can support transitions to democracy but unintentionally make democratic backsliding more likely in new democracies. Specifically, I identify three interrelated mechanisms linking IOs to democratic backsliding. These organizations neglect to support democratic institutions other than executives and elections; they increase relative executive power; and they limit states' domestic policy options via requirements for membership. Limited policy options stunt the development of representative institutions and make it more difficult for leaders to govern. Unable to appeal to voters based on records of effective governance or policy alternatives, executives manipulate weak institutions to maintain power, thus increasing the likelihood of backsliding.
\end{abstract}


Empirically, this dissertation makes several contributions. First, I create and validate a latent variable-based cross-national indicator, the Democratic Institutional Strength (DIS) index. The DIS index draws on a theoretically based conceptualization of democratic backsliding, an increasingly important concept for which there had been no previous metric. Second, I combine original and existing panel data to test my theory and find that membership in IOs associated with democracy promotion makes subsequent democratic backsliding more likely. Such IOs also lead to reduced checks on executive power, limited economic policy options, and stunted party development in new democracies. Case studies of democratic backsliding in the European Union (EU) illuminate these causal mechanisms. Focusing on the EU's two most extreme cases to date, Hungary and Poland, I illustrate how EU requirements contribute to backsliding by decreasing states' domestic policy space and increasing executive power. The theory and findings contribute to debates on how international factors impact domestic outcomes, especially processes of democratization, as well as to nascent theories of democratic backsliding. 
This is dedicated to my parents, Seth, and Minette, all of whom have been unfailing sources of love, support, and purrs. 


\section{Acknowledgments}

This dissertation is a result of invaluable support I received throughout my six years at The Ohio State University. I am particularly indebted to my co-chairs, Alexander Thompson and Irfan Nooruddin, without whom this project would not exist. I cannot thank Alex enough for agreeing to advise what was initially a heavily comparative dissertation, his guidance as I identified the international relations component of my research, his conscientious advising and feedback on countless drafts of this project, and his willingness to spend two or more hours per meeting helping me through my latest crisis with a combination of intellectual guidance and exceedingly dry wit. I also want to thank Irfan in particular for sparking the initial idea for this project during my first year at Ohio State, for introducing me to countless amazing and kind political scientists around the country, for helping me navigate the publishing process, and for breaking up the drudgery of conferences with group gatherings. Thank you for the long-distance support of your "last" Ohio State student.

I am equally thankful to my other committee members, in particular for their day-to-day advising and emotional support. I thank Sara Watson for our countless meetings, our research forays into the French Senate, and her constant consideration for my personal as well as professional well-being and her unwaveringly positive outlook. Most if not all of the analyses in this project would have been problematic 
without William Minozzi, who, along with Jason Morgan, became a sort of quantitative methods sherpa for my cohort. Finally, I thank Marcus Kurtz for forcing me to think hard about the design and assumptions in this project as well as his ongoing support as my graduate path evolved over time.

In addition to my committee, my other colleagues at Ohio State have been critical sources of support and intellectual inspiration. My cohort, over the course of our innumerable workshops and other informal meetings, should be commended for reading countless drafts of my work, and helping me realize not only when what I said was absolute nonsense, but also helping me identify solutions. I am especially thankful for their willingness to accept me as the "only girl" in the group and for an inordinate amount of time spent gossiping in offices and at bars. I am also thankful for my female colleagues from other cohorts that became a constant source of support and friendship, especially Leyla Tosun, Ruthie Pertsis, and Linnea Turco. These fellow graduate students, along with Macarena Guerrero and Amy Knuppe, have become lifelong friends for whom I am immensely grateful.

I would not have reached this point without the unconditional love and support from my family and long-distance friends. I especially want to thank my parents, who never seem to doubt that I can do anything I want, as well as my friends who have been there from the beginning, especially Kate, Elizabeth, Vanessa, Nuray, Allie, Julie, and Danielle.

Finally, I thank my partner, Seth. Through all my doubts, all my missteps, and also through my successes, he has always believed in, supported, and, when necessary, tolerated me. 


\section{Vita}

\begin{tabular}{|c|c|}
\hline 2012 & $\begin{array}{l}\text { B.A. International Studies, } \\
\text { Rhodes College }\end{array}$ \\
\hline $2013-2018$ & $\begin{array}{l}\text { Graduate Associate, } \\
\text { The Ohio State University }\end{array}$ \\
\hline 2015 & $\begin{array}{l}\text { M.A. Political Science, } \\
\text { The Ohio State University }\end{array}$ \\
\hline $2017-2018$ & $\begin{array}{l}\text { Virtual Student Federal Service E- } \\
\text { Intern, } \\
\text { United States Agency for International } \\
\text { Development, } \\
\text { Democracy, Human Rights, and Gov- } \\
\text { ernance Center }\end{array}$ \\
\hline
\end{tabular}

\section{Publications}

\section{Research Publications}

Meyerrose, A. M. (2018). It is all about value: How domestic party brands influence voting patterns in the European Parliament. Governance, 31(4), 625-642.

Meyerrose, A. M., Flores, T. E., \& Nooruddin, I. (2019). From Elections to Democracy in Hard Times. In Oxford research encyclopedia of politics. University of Oxford Press.

\section{Fields of Study}

Major Field: Political Science 


\section{Table of Contents}

Page

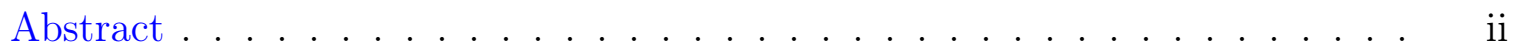

Dedication ...................... iv

Acknowledgments . . . . . . . . . . . . . . . . . v

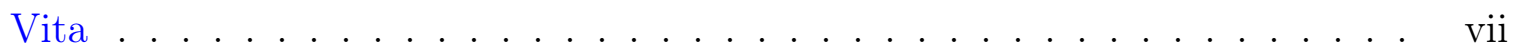

List of Tables . . . . . . . . . . . . . . . . . . . . xi

List of Figures $\ldots \ldots \ldots \ldots \ldots \ldots \ldots \ldots \ldots \ldots \ldots \ldots \ldots$

1. Introduction: Democratic Backsliding in an Age of International Democracy Promotion . . . . . . . . . . . . . . . . 1

1.1 Research Design . . . . . . . . . . . . . . . . . 9

1.2 Plan of the Dissertation . . . . . . . . . . . . . 13

2. Conceptualizing and Measuring Democratic Backsliding: The Democratic Institutional Strength Index . . . . . . . . . . . . . . . . . 16

2.1 Democracy and Democratic Backsliding . . . . . . . . . . . 19

2.1.1 What Is Democracy? . . . . . . . . . . . . . . . . . 19

2.1.2 Theories of Autocratic Reversion . . . . . . . . . . . . 21

2.1.3 Defining Democratic Backsliding . . . . . . . . . . . . 24

2.2 The Democratic Institutional Strength Index $\ldots \ldots \ldots \ldots \ldots$

2.2 .1 DIS Measurement Validation . . . . . . . . . . . . 36

2.3 Next Steps . . . . . . . . . . . . . . . . . . . . . . . . . . 39 
3. A Theory of International Organizations and Democratic Backsliding . . 42

3.1 Existing Theories of Democratic Backsliding . . . . . . . . . . 45

3.2 The International Side of Democracy . . . . . . . . . . . . . . . . . . . 47

3.3 International Organizations and Democracy . . . . . . . . . . . . 49

3.3.1 Why Do IOs Promote Democracy? . . . . . . . . . . . . 50

3.3.2 Which IOs Promote Democracy? . . . . . . . . . . . . . . 53

3.4 Theoretical Framework: Linking International Organizations and Democratic Backsliding . . . . . . . . . . . 54

3.4.1 Indirect Mechanism: Neglecting Important Democratic Institutions . . . . . . . . . . . . . . . . 55

3.4.2 Direct Mechanism 1: Increasing Executive Power . . . . . . 58

3.4.3 Direct Mechanism 2: Limiting the Domestic Policy Space . 60

3.5 Scope Conditions . . . . . . . . . . . . . . . . 65

3.6 Alternative Explanations . . . . . . . . . . . . . . . . . . . . 69

3.7 The Counterfactual and Research Design . . . . . . . . . . . . . . 74

4. Linking International Organizations to Democratic Backsliding: A CrossNational Analysis . . . . . . . . . . . . . . . . . . 78

4.1 Research Design . . . . . . . . . . . . . . . . . . . 79

4.1.1 Dependent Variable: The DIS Index . . . . . . . . . . . . . 80

4.1.2 Independent Variables: IO Membership . . . . . . . . . . . 80

4.1.3 Control Variables . . . . . . . . . . . . . . . 85

4.2 Results ...................... . . 86

4.2.1 Robustness Checks . . . . . . . . . . . . . . . . 90

4.2.2 Extension: Variation in IO Democracy Promoting Tools . . 96

4.3 Testing the Mechanisms . . . . . . . . . . . . . . . . 100

4.3.1 Executive Power . . . . . . . . . . . . . . . . . 100

4.3.2 Domestic Policy Space . . . . . . . . . . . . . . 105

5. Democratic Backsliding in the European Union . . . . . . . . . . . . . 115

5.1 Applying the Theoretical Framework to the European Union . . . . 118

5.1 .1 The EU and Executive Power . . . . . . . . . . . . . . . 119

5.1.2 The EU and the Domestic Policy Space . . . . . . . . . . 121

5.2 Research Design . . . . . . . . . . . . . . . . . . . 124

5.3 The Accession Process in Spain and Portugal . . . . . . . . . . . . 130

5.4 Synthetic Case Study: The Impact of EU Accession on Democracy in Hungary . . . . . . . . . . . . . . . . . . . . . 133

5.4.1 Method, Data, and Sample ........... 135 
5.4.2 The Impact of EU Accession in Hungary . . . . . . . . . . . . 137

5.5 Tracing Democratic Backsliding in Hungary and Poland . . . . . . 141

5.5.1 Executive Power . . . . . . . . . . . . . . . . . 144

5.5.2 Domestic Policy Space . . . . . . . . . . . . . . . . 153

6. Conclusion . . . . . . . . . . . . . . . . . . 163

6.1 Extensions and Areas for Future Research . . . . . . . . . . . . . 166

6.2 Policy Implications . . . . . . . . . . . . . . . . . . . . . . . . 168

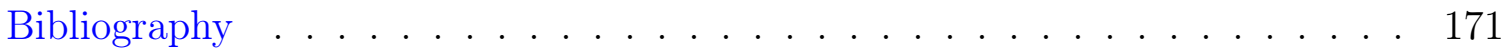

Appendices

A. Appendix to Chapter $4 \ldots \ldots$. . . . . . . . . . . . . . 192

A.1 Number of IO Memberships and Democratic Backsliding: Multilevel Models with Varying Intercepts by Country or Region . . . . . . .

A.2 Number of IO Memberships and Democratic Backsliding: Country and Year Fixed Effects . . . . . . . . . . . . . . . . . . 195

A.3 Number of IO Memberships and Democratic Backsliding: International Factors . . . . . . . . . . . . . . . . . . . . . . . . 197

A.4 Number of IO Memberships and Democratic Backsliding: 3-, 7-, and 10-Year Changes . . . . . . . . . . . . . . . . . . . . . . . .

A.5 Number of IO Memberships and Democratic Backsliding: International Factors, 3-, 7-, and 10-Year Changes . . . . . . . . . . . . 203

A.6 Number of IO Memberships and Democratic Backsliding: Pre- vs. Post-Cold War Eras . . . . . . . . . . . . . . . . . . . . . . 207

A.7 Number of IO Memberships and Democratic Backsliding: Alternative Dependent Variable . . . . . . . . . . . . . . . . . . 210

A.8 Number of IO Memberships and Democratic Backsliding: Two-Stage Selection Models . . . . . . . . . . . . . . . . . . . . 212

A.9 Number of IO Memberships and Democratic Backsliding: Democracies and Anocracies . . . . . . . . . . . . . . . . 215

A.10 Number of IO Memberships and Democratic Backsliding: No European Union . . . . . . . . . . . . . . . . . . . . . 217

A.11 Number of IO Memberships and Democratic Backsliding: Placebo Tests . . . . . . . . . . . . . . . . . . . 219 


\section{List of Tables}

Table

Page

2.1 Factors in the DIS Index Model . . . . . . . . . . . . . . . . 34

2.2 The DIS Index Incorporates a Wider Range of Institutional Indicators Relevant to Backsliding When Compared to Other Commonly Used Regime Type Variables. . . . . . . . . . . . . . . . . 36

4.1 Democratically Committed IOs Reference Support for Democracy, Human Rights, and/or Rule of Law in Their Constitutive Documents (von Borzyskowski and Vabulas, 2018). . . . . . . . . . . . . 82

4.2 International Organizations Relevant to Democratic Outcomes . . . . 84

4.3 Summary Statistics. IOs and Democratic Backsliding . . . . . . . . 87

4.4 Number of IO Memberships and Democratic Backsliding. Varying Intercepts by Country and Region . . . . . . . . . . . . . . .

4.5 Types of Democracy Promotion and Democratic Backsliding. Varying Intercepts by Country and Region . . . . . . . . . . . . . . . . . . 98

4.6 Summary Statistics. Executive Power . . . . . . . . . . . . . . 103

4.7 Number of IO Memberships and Checks on Executive Power . . . . . 104

4.8 Summary Statistics. Domestic Policy Space . . . . . . . . . . . . 108

4.9 Number of IO Memberships and Domestic Policy Space. Fraser Compromise Index . . . . . . . . . . . . . . . . . . . . . . 110

4.10 Number of IO Memberships and Domestic Policy Space. Inflation Rate 111 
4.11 Number of IO Memberships and Domestic Policy Space. Distinct Party Platforms . . . . . . . . . . . . . . . . . 114

5.1 Democracy Predictor Means before EU Accession . . . . . . . . . . . 136

5.2 Pre-Accession Aid (Phare) Allocation in Hungary and Poland, 1999-2002150

A.1 Number of IO Memberships and Democratic Backsliding: Varying Intercepts by Country . . . . . . . . . . . . . . . . . . . 193

A.2 Number of IO Memberships and Democratic Backsliding: Varying Intercepts by Region . . . . . . . . . . . . . . . . . . . . . 194

A.3 Number of IO Memberships and Democratic Backsliding, Country and Year Fixed Effects . . . . . . . . . . . . . . 196

A.4 Number of IO Memberships and Democratic Backsliding: International Factors . . . . . . . . . . . . . . . . . . . . . 198

A.5 Number of IO Memberships and Democratic Backsliding, 3 Years . . 200

A.6 Number of IO Memberships and Democratic Backsliding, 7 Years . . 201

A.7 Number of IO Memberships and Democratic Backsliding, 10 Years . . 202

A.8 Number of IO Memberships and Democratic Backsliding: International Factors, 3 Years . . . . . . . . . . . . . . . . . . . . 204

A.9 Number of IO Memberships and Democratic Backsliding: International Factors, 7 Years . . . . . . . . . . . . . . . 205

A.10 Number of IO Memberships and Democratic Backsliding: International Factors, 10 Years . . . . . . . . . . . . . . 206

A.11 Number of IO Memberships and Democratic Backsliding: Varying Intercepts by Country and Region, 1945-1989 . . . . . . . . . . . . . . 208

A.12 Number of IO Memberships and Democratic Backsliding: Varying Intercepts by Country and Region, 1990-2015 . . . . . . . . . . . . . . 209 
A.13 Number of IO Memberships and Democratic Backsliding: Alternative Dependent Variable . . . . . . . . . . . . . . . . . . . . . . 211

A.14 Selection Models (First Stage) . . . . . . . . . . . . . . . 213

A.15 Number of IO Memberships and Democratic Backsliding with Selection Correction and Robust Standard Errors (Second Stage) . . . . . . . 214

A.16 Number of IO Memberships and Democratic Backsliding: Democracies and Anocracies . . . . . . . . . . . . . . . . 216

A.17 Number of IO Memberships and Democratic Backsliding: No European Union . . . . . . . . . . . . . . . . . . . . . . . . . 218

A.18 Number of IO Memberships and Democratic Backsliding: Placebo . . 221

A.19 Number of IO Memberships and Democratic Backsliding: International Factors, Placebo . . . . . . . . . . . . . . . . . . 222 


\section{List of Figures}

Figure

Page

1.1 The percent of all IOs that either support or actively engage in democracy promotion has steadily increased since the end of the Cold War (von Borzyskowski and Vabulas, 2018). . . . . . . . . . . .

1.2 Democratic backsliding is a worldwide phenomenon that has become increasingly common despite extensive international support for democracy. . . . . . . . . . . . . . . . . .

2.1 Democratic backsliding occurs when a state becomes less democratic without reverting to autocracy. . . . . . . . . . . . . .

2.2 The Bayesian latent variable model that I use to combine the indicators from Table 2.1 creates the DIS index, a continuous variable designed specifically to capture democratic backsliding. . . . . . . . . . .

2.3 Unlike Polity and Freedom House, the DIS index picks up on prevalent cases of democratic backsliding. . . . . . . . . . . . . . . 37

2.4 DIS index for select countries. . . . . . . . . . . . . . . . . 40

4.1 Democratically committed international organizations use a range of tools to promote democracy among their member states. . . . . . . . 97

5.1 Democracy levels over time in all 2004 EU accession states. . . . . . . 125

5.2 Democracy levels in the Visegrad region have declined since these countries joined the EU in 2004. . . . . . . . . . . . . . . . . . 126

5.3 With the exception of Estonia, democracy levels in the Baltics have declined or stagnated since these countries joined the EU in 2004. . . 
5.4 Unlike Hungary and Poland, for the first two decades after joining the EU, Spain's and Portugal's levels of democracy steadily rose. . . . . . 129

5.5 Hungary and the synthetic case have nearly identical democratic trajectories in the pre-accession period. Following Hungary's accession to the EU in 2004, Hungary's level of democracy diverges. . . . . . . . . 138

5.6 Hungary's and synthetic Hungary have similar liberal democracy scores prior to 2004; however, after joining the EU, Hungary's democracy score drops when compared to synthetic Hungary's. . . . . . . . . . . 139

5.7 Hungary and synthetic Hungary's levels of democracy do not diverge substantially following the placebo treatment. This suggests that the results from Figure 5.5 are not merely driven by poor predictive power of the synthetic control. . . . . . . . . . . . . . . . 140

5.8 There is no identifiable treatment effect of EU accession on Uruguay, the control case that was most similar to Hungary in the pre-treatment period. This provides further support for the finding that joining the EU impacted Hungary's democratic trajectory. . . . . . . . . . . . . . 142

5.9 On average, western European legislatures and judiciaries have more control over their executives, and executives in the West adhere to the constitution more closely than their counterparts in Hungary and Poland.148

5.10 Economic issues are less prominent than non-economic ones in Hungarian and Polish party manifestos. The emphasis on non-economic issues became particularly strong following EU accession. . . . . . . . 157

5.11 At the same time that mentions of economic issues have been on the decline in Hungary and Poland, western European parties on average have given increased attention to these same topics. Similarly, while mentions of non-economic issues in Hungary and Poland have steadily risen, they have been decreasing among western European parties. . . 158 


\section{Chapter 1: Introduction: Democratic Backsliding in an Age of International Democracy Promotion}

The fall of the Soviet Union and the end of the Cold War were heralded as the "end of history" (Fukuyama, 1989), marked by the triumph of western democracy and economic liberalism. One artifact of this perceived ideological victory was a sharp increase in international democracy promotion beginning in the 1980s, and continuing into the present.

International and especially regional organizations are often at the forefront of democracy promotion. As Figure 1.1 illustrates, the percent of international organizations (IOs) that reference support for either democracy, human rights, and/or rule of law in their founding charters or other official documents has risen significantly over time. What is more, scholars overwhelmingly find IOs are positive forces for democracy and even democratic consolidation, or, long-term democratic survival (Donno, 2013a; Mansfield and Pevehouse, 2008; Nygard, 2017; Pevehouse, 2005; Poast and Urpelainen, 2018).

However, this increased emphasis on democracy has more recently been accompanied by rampant illiberalism and a sharp rise in cases of democratic backsliding in new democracies whose transitions to democracy were heavily influenced and supported by the international community. For example, in 2004 Hungary and Poland 


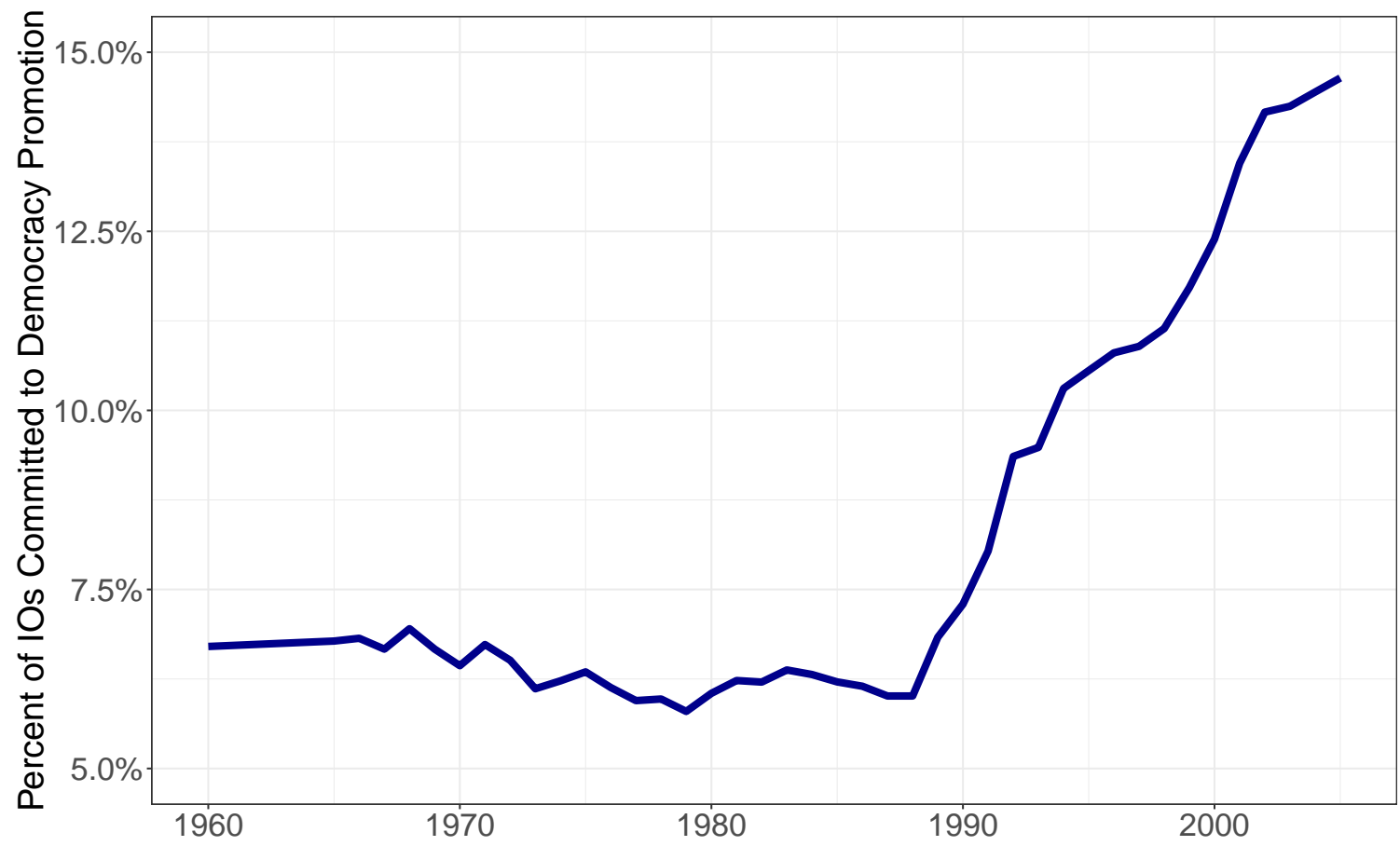

Figure 1.1: The percent of all IOs that either support or actively engage in democracy promotion has steadily increased since the end of the Cold War (von Borzyskowski and Vabulas, 2018). 
became members of the European Union (EU), an IO strongly associated with democracy promotion. However, beginning in 2011, the Hungarian Prime Minister, Viktor Orbán, eliminated significant constitutional checks on executive power, diminished the independence of the judiciary, limited media pluralism, and modified the electoral system - all by legal means - to facilitate the continued dominance of his party. Orbán went so far as to publicly proclaim liberal democracy has failed in Hungary, advocating instead a form of illiberal democracy. Poland embarked on a comparable trajectory when the Law and Justice party came to power in 2015 and began a campaign of concerted attacks against the media and the independence of the judiciary, with a particular focus on the constitutional court.

Even in the Czech Republic, which has long been regarded as a particularly successful case of post-communist democracy in Europe, there have been signs of democratic erosion. In 2013, the country's first directly elected president, Milos̆ Zeman, took actions to shift from a parliamentary system to a semi-presidential one by appointing a technocratic government (Dawson and Hanley, 2016). Zeman has joked about murdering opposition journalists, and his prime minister has expressed interest in dismantling democratic institutions. Zeman was re-elected president of the Czech Republic in 2018 (Ereli, 2018; Ringen, 2018).

These anti-democratic trends are not unique to Europe but rather have also emerged in a number of other new democracies around the world. For example, the current Bolivian President, Evo Morales, was first elected in 2005, and his power has increased significantly since then. After coming to power, Morales re-wrote the Bolivian constitution to expedite his reforms and has more recently been accused of attacking the news media and packing national courts with his supporters. In 2016, 
the Bolivian government held a referendum to allow citizens to determine if Morales should be allowed to run for a fourth term in 2019. Although voters rejected the referendum, Bolivia's highest court subsequently eliminated term limits, and Morales has announced his intent to run for re-election in 2019 (Human Rights Watch, 2010).

Even more extreme attacks against democracy in Latin American have emerged in Venezuela. In 1998, Venezuela's President Hugo Chavez adopted a new constitution that strengthened the powers of the president while simultaneously weakening the opposition-led legislature and packing the judiciary with ruling party loyalists, all without abandoning contested elections. More recently, Chavez's successor, Nicolás Maduro, has taken steps to limit the ability of the opposition to pass legislation, and won his most recent election in May 2018 amid accusations that the elections no longer met international standards of freedom and fairness (Watch, 2019). Maduro has become increasingly violent in response to protests against his government and as of April 2019 is facing increasing international pressure to step down (Sullivan, 2019).

Democracy has also been challenged in India since 2014 when Prime Minister Narendra Modi was elected, and his Bharatiya Janata Party (BJP) won a strong majority in the national parliament. For example, in 2018, a former Modi aide and Governor of the Indian state of Karnataka, Vajubhai Vala, violated constitutional mandates by refusing to invite a non-BJP party to form government, even after they won an election. At the national level, the BJP has taken steps to block the opposition in parliament from calling a vote of no confidence against Modi. Furthermore, senior justices within the Supreme Court maintain that the chief justice, facing blackmail from the ruling BJP party, has relegated politically sensitive cases to carefully selected 
groups of justices, thereby undermining judicial independence. Similarly, prominent news outlets have increasingly supported the ruling party, while the Indian Election Commission has been accused of modifying election dates to favor Modi (Bal, 2018). Similar and more extreme trends have emerged in Mexico, Malawi, Turkey, the Philippines, and other new democracies, despite their membership in IOs associated with democracy and democracy promotion, such as the Organization of American States, the African Union, the Council of Europe, and the Association of Southeast Asian Nations (ASEAN).

Indeed, increased emphasis on international democracy promotion by IOs has been followed by a spike in cases of democratic backsliding around the world. Figure 1.2 traces the annual percentage of democracies on each continent that have exhibited backsliding. ${ }^{1}$ Overall, the number of cases of backsliding has risen over time. This is even the case in Europe and the Americas, which are historically the two most densely democratic regions in the world.

What explains democratic backsliding in an age of unparalleled international support for democracy? Democratic backsliding occurs when elected officials weaken or erode democratic institutions and results in an illiberal or diminished form of democracy, rather than autocracy. As such, democratic backsliding is a process unique to democracies, or, states that meet the minimal procedural requirements to be considered democratic: relatively free and fair elections coupled with mass participation in

\footnotetext{
${ }^{1}$ I use my original indicator of democratic backsliding, the Democratic Institutional Strength (DIS) index, formally introduced in Chapter 2, to capture backsliding over time. Here, I define democracies as country-years with a Polity score greater than 5. A case is coded as an instance of backsliding if the change from year $t-5$ to year $t$ along the DIS index is negative. I focus on 5 -year periods, as opposed to year-to-year changes, since democratic backsliding is an incremental process rather than one that occurs suddenly, such as a coup (Waldner and Lust, 2018).
} 


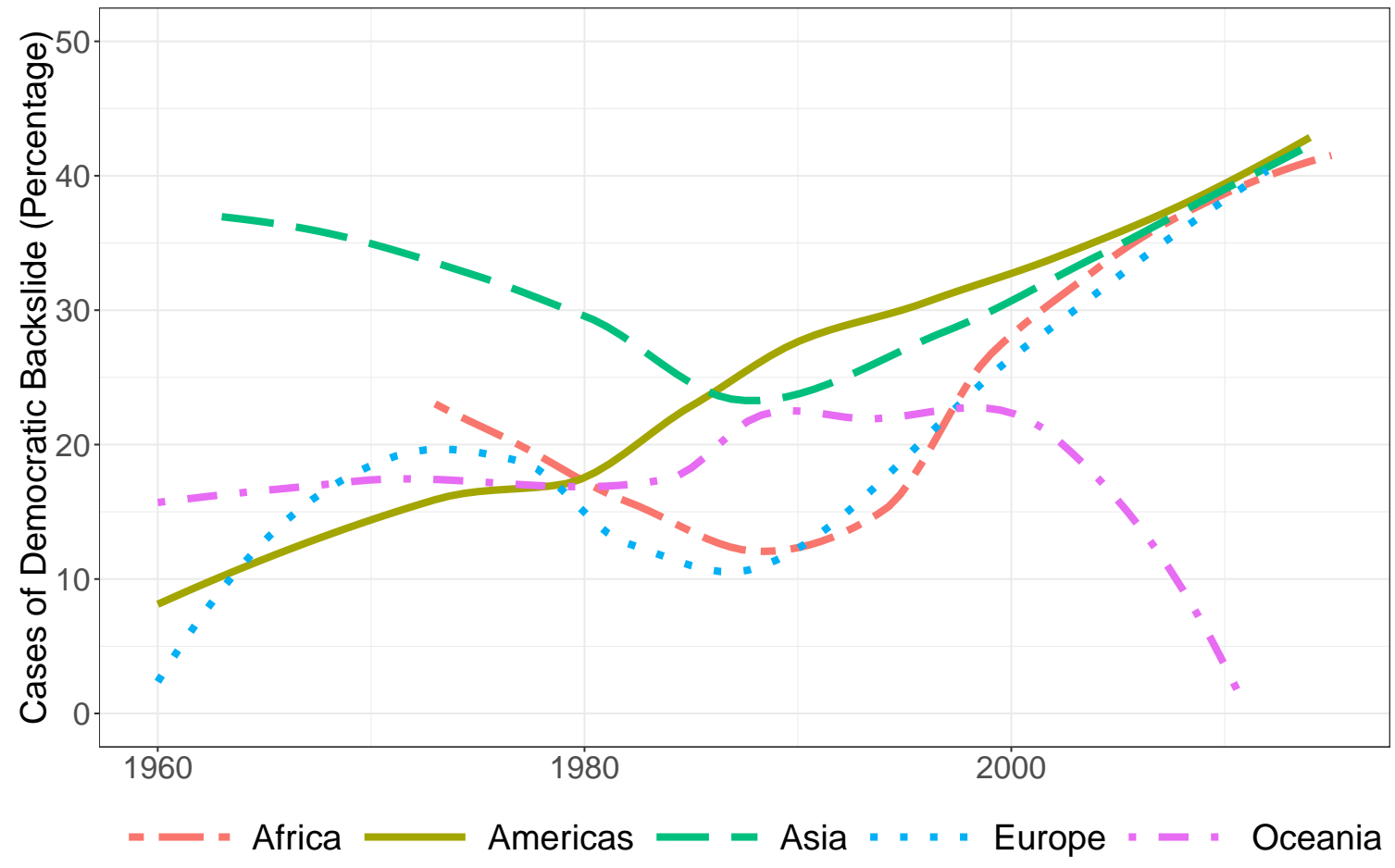

Figure 1.2: Democratic backsliding is a worldwide phenomenon that has become increasingly common despite extensive international support for democracy. 
politics (Dahl, 1971). Although research has identified case-specific sources of backsliding (Berman, 2016; Hanley and Sikk, 2016; Hernandez and Kriesi, 2016; Krastev, 2016; Rupnik, 2016), no systematic theories of this phenomenon exist (Waldner and Lust, 2018). On the international side, authors have critiqued democracy assistance and suggested it can even have deleterious effects (Bush, 2015; Henderson, 2003; Savage, 2017; Wedel, 2001), while others have shown how regional powers may engage in autocracy promotion (Finkel and Brudny, 2012). However, few have investigated the role of IOs in particular and how they might be contributing to these illiberal trends.

Drawing on institutional theories of democracy, I argue that although IOs often serve as a critical initial impetus for states to transition to democracy, they also unintentionally sow the seeds for future democratic erosion and backsliding in new democracies. They do this by both failing to support, and even stunting, the development of democratic institutions. Democratic success is contingent upon the strength of institutions that organize mass participation in politics, aggregate societal interests, and enable the state to both govern effectively, and, critically, limit itself (Huntington, 1968). These institutions include political parties, strong legislatures, independent judiciaries, and general state capacity. IOs commonly associated with democracy promotion focus predominantly on elites and elections but neglect to support these other democratic institutions. This narrow focus makes new democracies more susceptible to democratic backsliding.

In addition to neglecting to support important democratic institutions, IOs also more directly alter the domestic institutional landscape and contribute to backsliding in new democracies in two ways. First, as a by-product of how they interact with states, IOs increase relative executive power. Democracy promotion by IOs focuses 
in particular on elite incentives and resources, and executives serve as the primary intermediaries between their states and IOs. This shifts the domestic balance of power in favor of executives.

Second, IO conditionality and membership requirements limit states' economic and other domestic policy options; this impedes institutional development. Political parties and legislatures in new democracies become institutionalized by advocating and debating meaningful policy alternatives. However, when options are limited by external requirements, these institutions remain underdeveloped. Diminished policy options also constrain leaders' ability to govern effectively and provide public goods. Unable to appeal to voters based on records of effective governance or policy alternatives, executives instead manipulate or erode democratic institutions - such as the constitution, judicial independence, and media freedom - to maintain power. This is easier when horizontal institutions of accountability, such as parties and legislatures, are weak. In these ways, IO-induced institutional shifts make democratic backsliding more likely.

This dissertation project contributes to research on IOs and regime outcomes, which finds that IOs can promote transitions to democracy and even democratic consolidation (Pevehouse, 2005; Poast and Urpelainen, 2018; Mansfield and Pevehouse, 2006). The theory and findings presented here suggest the well-established link between IOs and democracy is correct: in the aggregate, the two are positively associated. However, existing research is less clear about how these organizations impact domestic institutions that influence a state's quality of democracy in the long term. My findings suggest that IOs support and preserve democracy in a minimal sense but are less effective at promoting - and can even impede - further democratic 
institutional development and progress in new democracies. In addition to speaking to the literature on IOs and democracy, this research also contributes to nascent theories of democratic backsliding by proposing two factors that may contribute to this emerging phenomenon: strong executives surrounded by weak institutions. Although I focus on the conditions under which IOs contribute to these domestic outcomes, relatively strong executives surrounded by weak institutions may also be sources of backsliding in states not subject to intense IO involvement.

\section{$1.1 \quad$ Research Design}

The argument developed in this dissertation does not refute existing research linking IOs to overall higher levels of democracy. As noted above, democratic backsliding is a process unique to democracies; therefore, the focus of this project is on a particular subset of developing countries: those that are democracies, and thus have been relatively successful examples of democratization. Undoubtedly, without support and incentives from IOs, these developing states would have been less likely to transition to democracy in the first place, and the overall outcome may have therefore been semi or even fully autocratic states rather than illiberal or diminished democracies.

Instead, the argument here builds on existing work on IOs and regime outcomes, taking it one step further. Although IOs are associated with overall higher levels of democracy when compared to autocracy, they are more limited in their ability to promote ongoing democratic progress among democracies and can even unintentionally create conditions conducive to backsliding. Using their current approaches to democracy promotion, these IOs are unable to promote anything beyond minimalist democracy, characterized primarily by free and fair elections and mass participation 
in politics, and they can even make backsliding more likely. This is because they focus predominantly on minimalist democratic institutions, alter the domestic institutional balance of power, and constrain the domestic policy space.

Therefore, the relevant counterfactual for this theory would be a situation in which IOs continue to create incentives and provide support for states to transition to democracy, yet they approach membership requirements for new democracies differently, in several ways. First, in this counterfactual world, IOs would not impose extensive policy requirements on new democracies before they have developed important democratic institutions, in addition to elections, that can act as a check on executive power. Furthermore, these IOs might instead channel more resources toward actively building up these critical representative institutions and institutional checks on executive power, such as legislatures, political party systems, civil society, independent judiciaries, and the media, rather than focusing exclusively on elections and elites. This would require both more oversight on the part of IOs and also longer time horizons to allow domestic institutions to develop from the bottom-up, with external aid.

Testing this theory poses several challenges, many of which revolve around the fact that few if any counterfactual cases exist, for several reasons. First, all new democracies, or at least those that have been relatively successful democracies, are members of these IOs that engage in democracy support and promotion. What is more, these states began joining these IOs shortly after their transitions to democracy (Mansfield and Pevehouse, 2008). Therefore, there are no (successful) observable cases of democratization without heavy influence from IOs. Furthermore, due to the extensive emphasis that the international community has placed on free and fair elections as 
a signal and initial phase of democratization, most democracy promoting IOs focus heavily on these minimalist forms of democracy promotion (Schedler, 2002; Howard and Roessler, 2006; Hadenius and Teorell, 2007). As such, there are few empirical cases of alternative forms of democracy promotion to leverage as counterfactual treatments.

Given these limitations, I rely on observational data and adopt a multi-method approach to test my argument and approximate the counterfactual. Specifically, I combine cross-national analysis, which I use to test the plausibility of the proposed relationship between IOs and democratic backsliding, with an in-depth case study of the EU to more directly trace the proposed mechanisms. Specifically, in Chapter 4, I use both original and existing data to test the overarching prediction of my theory: increased membership in democratically relevant IOs is associated with subsequent backsliding in new democracies. I also use cross-national data to test the proposed direct mechanisms linking IOs and backsliding: increased executive power and a diminished domestic policy space. With this analysis, I find evidence that as the number of democracy promoting IOs a new democracy is a member of increases, its probability of experiencing subsequent democratic backsliding rises, executive power increases, and the domestic policy space shrinks. As a first attempt at approximating the counterfactual, I also conduct several placebo tests. Although the results are not consistent throughout, in the full models I find that IOs not predicted to influence democratic outcomes in their member states have no significant relationship with states' probabilities of backsliding. This suggests that the main models are picking up on a meaningful relationship between membership in relevant IOs and democratic backsliding. 
Since this cross-national study can only pick up on correlations, I supplement this analysis with an in-depth case study of the EU. This case study leverages process tracing, comparative case studies, and the synthetic control method, all of which have been used to trace causal mechanisms linking an explanatory variable to the outcome of interest (Mahoney, 2000) or to more closely approximate the counterfactual (Abadie et al., 2015; Ragin, 1987; Seawright and Gerring, 2008). According to existing research, of all IOs, the EU is one of, if not the best, at promoting transitions to democracy and supporting further democratic progress among its member states (Dimitrova and Pridham, 2004; Ekiert, 2008; Levitz and Pop-Eleches, 2010; Noutcheva, 2016; Smith, 2001). As such, this should be a particularly hard case for my theory: if there is evidence linking the EU to backsliding, this would provide further support for my theory. Indeed, despite the EU's extensive democratic credentials, there has recently been evidence of backsliding in several of its newly democratic member states. Focusing on the two most extreme cases of backsliding to date in the EU-Hungary and Poland - I use process tracing to show the ways in which the EU increased executive power and limited policy options as these two countries were initially developing their democratic institutions.

I also use this case study of the EU to approximate the counterfactual in two ways. First, I compare Hungary and Poland to two approximations of the counterfactualSpain and Portugal - two other new democracies in the EU that have not experienced backsliding. In contrast to Hungary and Poland, membership conditionality for Spain and Portugal was much less extensive, occurred on much more of an ad hoc basis, and required the adoption of significantly fewer domestic policies than was the case for Hungary and Poland. I argue that these differences in the accession processes, all 
of which occurred shortly after these four states' transitions to democracy, in part account for the relative success of democracy in Spain and Portugal when compared to Hungary and Poland.

However, since there are important differences between Hungary and Poland on one hand and Spain and Portugal on the other, I also leverage the synthetic case study method to estimate the impact of EU accession on Hungary's democratic trajectory. In the synthetic control method, a comparison unit is constructed using "the weighted average of all potential comparison units that best resembles the characteristics of the case of interest" (Abadie et al., 2015, 496). This allows me to construct a case that is similar to pre-accession Hungary along dimensions that predict democratic success and then to observe the trajectory of the synthetic case's level of democracy absent treatment (EU accession). I find evidence that joining the EU negatively impacted Hungary's subsequent democratic trajectory.

\subsection{Plan of the Dissertation}

This project proceeds in several steps. Since democratic backsliding is a relatively new phenomenon, definitions of the concept vary widely across authors, and there is no existing variable to measure it. Therefore, Chapter 2 begins by developing a theoretically grounded definition of backsliding and then builds on this conceptualization to develop an original, Bayesian latent variable to measure backsliding cross-nationally and over time. I call this index the Democratic Institutional Strength (DIS) index. Chapter 2 concludes with descriptive statistics of the DIS index to validate it as a measure of backsliding. 
Next, in Chapter 3, I develop a theoretical framework linking membership in democratically relevant IOs to backsliding in new democracies around the world. This chapter begins by giving an overview of existing theories of backsliding, which are still developing and focuses primarily on domestic-level sources of this emerging phenomenon. However, since many of the states that are backsliding were heavily influenced by international factors during their transitions to democracy, the next section of the chapter outlines existing work on international sources of democratization. Because IOs are often at the core of studies of democracy promotion, the following section outlines the literature and related positive expectations about the impact of IOs on democratic development. With this context outlined, the chapter then proposes an original theory for why IOs may not be as effective at promoting democracy as existing work suggests, outlining one indirect and two direct proposed mechanisms linking IO membership to democratic backsliding in new democracies. After outlining the theory and the related empirical expectations, the subsequent sections discuss the scope conditions of the theory and possible alternative explanations. Finally, the chapter concludes with a discussion of the relevant counterfactual for this theory.

Chapters 4 and 5 are the core empirical chapters of the project. As discussed above, Chapter 4 consists of a cross-national test of the proposed theory linking membership in democratically committed IOs to backsliding in new democracies. After finding evidence in support of the overarching theory, this chapter then tests and finds support for the proposed mechanisms linking IOs to backsliding: IO membership is associated with increased executive power and a limited domestic policy space. Building on the findings from Chapter 4, Chapter 5 develops the case study of the 
EU discussed above. Finally, Chapter 6 concludes with an overview of the findings as well as a discussion of the policy implications of these findings and avenues for future research. 


\section{Chapter 2: Conceptualizing and Measuring Democratic Backsliding: The Democratic Institutional Strength Index}

The growing emphasis on democracy promotion by international organizations (IOs), especially since the end of the Cold War, has more recently been followed by an increase in cases of backsliding around the world. Although research on regime outcomes is extensive, it is dominated by theories of democratization and democratic collapse, or cases where democracies fail and are replaced by autocracies. However, in the post-Cold War era, total democratic collapse has become an increasingly rare regime outcome: only 18 cases have been recorded since 1990 (Geddes et al., 2014). ${ }^{2}$

Instead, it is more common for democracies to experience democratic backsliding. Democratic backsliding occurs when elected officials weaken or erode institutional checks on government power (Bermeo, 2016), including the constitution, rule of law, civil and minority rights, the independence of the judiciary and the media, and separation of power within government (Maeda, 2010). Backsliding is a within-regime process (Waldner and Lust, 2018) distinct from autocratic reversion: the outcome is an illiberal, diminished, or minimalist form of democracy, not autocracy. The total dismantling of institutions that are minimally necessary for a state to be considered a democracy — specifically, open, free, and fair elections (Schumpeter, 1950) —would

${ }^{2}$ Armenia, Belarus, Burundi, Comoros, Congo, Dominican Republic, Ecuador, Fiji, Gambia, Haiti, Niger, Pakistan, Peru, Thailand, Sierra Leone, Suriname, Ukraine, and Zambia. 
be beyond the scope of democratic backsliding; this would more closely resemble democratic collapse or autocratic reversion.

This empirical shift from autocratic reversion and democratic collapse to democratic backsliding is likely related to changed international incentives for states to at least appear democratic. Following the end of the Cold War, democracy promotion became a prominent foreign policy objective for western powers. Direct democracy promotion, multilateral conditionality, democracy assistance, and transnational advocacy networks were all used to encourage democratization in the developing world (Levitsky and Way, 2010). One consequence of this increased emphasis on and heightened normative appeal of democracy was that states who were not deemed to be sufficiently democratic were excluded from a number of international benefits, such as foreign aid and membership in IOs, which were increasingly conditioned on regime type (Crawford, 2001; Levitsky and Way, 2002). These changed international incentives thus served to render autocratic reversion a less likely regime outcome and made it so that states no longer have the option to vacillate between democracy and autocracy. Instead, democratic backsliding has become more common.

However, despite the emergence of this new type of regime outcome, the literature has failed to develop a clear conceptualization of backsliding, and existing measures of regime outcomes, which were in large part developed to differentiate democracies from autocracies, are insufficient for capturing the often subtle changes that comprise backsliding. Indeed, the definition and very existence of democratic backsliding is contested (Diamond, 2008; Diamond and Plattner, 2015; Merkel, 2010; Rupnik, 2007), one result of which has been that the concept of democratic backsliding is "frequently used but rarely analyzed" (Bermeo, 2016, 5). 
I argue that part of the reason why the link between IOs and democratic backsliding has been overlooked in the existing literature is due to the fact that democratic backsliding is an under-conceptualized phenomenon that lacks a sufficient crossnational indicator. Indeed, there is no existing cross-national quantitative variable constructed specifically to measure democratic backsliding. Therefore, following Adcock and Collier (Adcock and Collier, 2001), this chapter proposes a theoretically grounded conceptualization of democratic backsliding as well as an original, Bayesian latent variable-based index for this increasingly prevalent phenomenon: the Democratic Institutional Strength (DIS) index.

To offer a theoretically based conceptualization of backsliding, the next section begins with a discussion of democracy more broadly, emphasizing in particular the differences between minimalist and more robust forms of democracy and the wide range of institutional dimensions relevant to a more expansive conceptualization of democracy. Next, I outline theories of autocratic reversion. While these theories provide some critical insights into the types of institutions that should predict democratic backsliding, they alone are insufficient to explain contemporary cases of backsliding. With this in mind, I propose a conceptualization of democratic backsliding that is related to, yet distinct from, autocratic reversion. Building on this definition and the related theoretical components, the following sections develop and present the DIS index, an original variable to capture backsliding cross-nationally. 


\subsection{Democracy and Democratic Backsliding}

\subsubsection{What Is Democracy?}

To define and measure backsliding, it is important to establish a common basis for what democracy entails. However, there is a range of different definitions of democracy in the existing literature, and empirically democracies can look quite different from one another (Collier and Levitsky, 1997; Dahl, 1971; Palma, 1990; Huntington, 1991; Lijphart, 1977; Linz and Stepan, 1996; Lipset, 1959; O’Donnell and Schmitter, 1986; Schmitter and Karl, 1991; Schumpeter, 1950).

Broadly speaking, there are two components of a democracy: the institutional component and the citizen component. In minimalist definitions of democracy, elections (institutions) and participation (citizens) are the two defining characteristics of democracy (Dahl, 1971). While classical debates (and the resulting indices) over the definition and measurement of democracy tend to focus on identifying the differences between democracies and non-democracies based solely on these minimalist characteristics (Dahl, 1971), more recent work has shifted to the quality of democracy, focusing instead on what distinguishes democracies from one another, especially at the institutional level (Geissel et al., 2016). For example, in addition to focusing solely on the extent to which citizens participate in free and fair elections, this research also considers the strength of representative institutions, such as political parties, legislatures, and civil society, institutions designed to safeguard civil liberties and rule of law, including independent judiciaries, media freedom, and the constitution. Since the outcome of backsliding is an illiberal or diminished form of democracy, not autocracy, work on the quality and gradations of democracy, rather than the distinction 
between democracies and autocracies based on minimalist procedural definitions of democracy, is a relevant starting point to begin conceptualizing backsliding.

This focus on the relative strength of institutional components that contribute to the quality of democracy, rather than just on minimalist characteristics of the concept, is further justified by considering the international community's views regarding democracy. Since the end of the Cold War especially, the international community has developed its own conceptualization for what it means by democracy and what its goals are when it engages in democracy promotion. This is essentially a western, liberal form of democracy that includes both inherently democratic institutions, such as free and fair elections, legislatures, and political parties, but also more liberal components of a state, such as guaranteed protection of human and minority rights (Mill, 1859; Rawls, 1993). In other words, the international community views democracy as something more than just procedural minimal requirements; in this way, the goals of international democracy promotion include additional dimensions of democracy that have been more recently highlighted by research on the quality of democracy.

Therefore, I rely on research that focuses on the institutional quality of democracy beyond minimalist characteristics, combined with the the international community's adoption of western liberal democracy as the goal of democracy promotion, to develop the below definition of democratic backsliding. Defined as such, the corresponding measure of backsliding that I propose will involve the erosion or dismantling of any one of a number of (liberal) democratic institutions but will fall short of the total dismantling of those minimalist characteristics that distinguish democracies from autocracies: mass participation in free and fair elections. 


\subsubsection{Theories of Autocratic Reversion}

Existing theories of regime outcomes as applied to third wave democracies ${ }^{3}$ have several shortcomings. First, these theories tend to focus on the factors that contribute to either democratic consolidation or autocratic reversion, or, a complete reversal from democracy to autocracy; the in-between state- democratic backsliding - is not considered. Thus, while the political institutional variables theorized to lead to autocratic reversion may also be sources of democratic backsliding, this has not been explicitly tested, and cannot be assumed. Furthermore, in many cases these theories do not hold empirically.

Most theories of regime outcomes are dominated by domestic-level explanations. Broadly speaking, this literature consists of theories that focus either on structural determinants of democratization or, alternatively, on key institutional factors. First, levels of economic development are often at the core of predictions about likely regime trajectories. However, when it comes to the third wave of democracy, many of the classic economic predictions about regime outcomes have come up short (Moore, 1966), and structural theories have failed to predict short-term patterns of democratization (Teorell, 2010). For example, Teorell finds that although modernization hinders authoritarian reversal, it does not lead to democratization in the third wave (Teorell, 2010). In fact, more recently, short-term economic improvements have actually sustained autocrats, whereas economic crises have triggered transitions to democracy (Przeworski and Limongi, 1997). Relatedly, theories about the effects of inequality on democratization (Boix, 2003; Acemoglu and Robinson, 2005) have been relatively

\footnotetext{
${ }^{3}$ Third wave democracies are states that transitioned to democracy in or after 1974 (Huntington, 1991).
} 
poor predictors of regime outcomes in third wave states (Haggard and Kaufman, 2012). Svolik takes a step toward addressing the short-comings of structural theories for predicting third wave regime outcomes by distinguishing between variables impacting democratic consolidation and those that lead to autocratic reversion. He finds that low levels of economic development, a presidential executive, and a military authoritarian past all reduce the likelihood of consolidation, while autocratic reversion is most likely when transitioning (unconsolidated) democracies experience an economic recession (Svolik, 2008).

In addition to economic recession, other domestic political institutional variables are theorized to influence regime outcomes in new democracies. These domestic political institutions include the rule of law (Bugaric, 2015), an independent judiciary (Issacharoff, 2015; Gibler and Randazzo, 2011), state capacity (Fortin, 2012), civil society (Blokker, 2013; Putnam, 1993), characteristics of the previous regime, and founding elections (Morlino, 2011). In addition, parliamentary political systems are found to lead to more stable forms of democracy when compared to presidential systems and are also more highly correlated with democratic consolidation (Linz, 1990; Stepan and Skach, 1993). Furthermore, institutions that effectively constrain the power of the executive have been identified as particularly important in determining democratic success. Indeed, executive constraints are especially relevant to the question of democratic success, yet checks on executive power tend to be weak in new, third wave democracies (Kapstein and Converse, 2008).

Political parties are one important source of checks on executive power. Compared to more mature democracies, many of the third wave states tend to have weakly 
institutionalized party systems. These less developed party systems are characterized by electoral volatility, high levels of personalism, and parties that are both less rooted in society and, relatedly, have lower levels of legitimacy. Unconsolidated party systems are argued to harm both the quality of democracy and also the prospects for democratic consolidation (Mainwaring, 1998), thereby making democratic backsliding a more likely outcome (Svolik, 2008). For example, extensive work on the post-communist EU member states has found that the EU's involvement in democratization in these states impeded party system development (Grzymalaa-Busse and Innes, 2003; Innes, 2002; Ladrech, 2008). Another, primarily domestic, proposed cause of weakly institutionalized party systems is the presence of parties that lack strong organizations. Tavits argues parties that invest in strong party organizations - which entails cultivating large memberships, developing extensive networks at the local level, and building professional and permanent central offices - are more likely to survive elections and behave cohesively in parliament (Tavits, 2013). Furthermore, parties with pragmatic, professional leaders tend to be more successful in new democracies than parties with ideologically driven leaders.

In sum, existing research on regime outcomes points toward the important role of political elites, party systems, and other institutional variables - as opposed to broad structural conditions - for explaining regime outcomes, especially in third wave democracies. However, these theories tend to focus predominantly on explaining democratic collapse, or complete reversions to autocracy, but tell us less about the sources of more subtle erosions of democracy, such as backsliding. 


\subsubsection{Defining Democratic Backsliding}

Democratic backsliding is a contested concept. Levitsky and Way argue that the recent (and what they believe to be false) perceptions of democratic backsliding can be attributed to the excessive optimism about democratization following the Cold War, which led to assumptions that many semi-authoritarian states were in the process of democratizing when in fact they never actually were (Levitsky and Way, 2015). Scholars that study new democracies in post-communist Europe have similarly argued that these states have experienced democratic slowdown but not necessarily reversal (Levitsky and Way, 2010). Sedelmeier, on the other hand, contends that post-2010 events in both Hungary and Romania serve as empirical challenges to the notion that democratic backsliding is a myth (Sedelmeier, 2014); Mexico, Bolivia, Colombia, Ecuador, and Venezuela have all also experienced backsliding to varying degrees recently (Serra, 2012), as have Senegal, Mali, and Fiji (Bermeo, 2016). More broadly, while agreeing there is evidence of democratic decline, Ostrow contends that liberal democracy is in fact under threat, arguing that recent legislation limiting the rights of minorities and migrants in Hungary, France, and Switzerland constitutes evidence of democratic decline in these states (Ostrow, 2014).

One explanation for the current lack of consensus about backsliding in the literature (both regarding whether it exists and what it is) may be related to the fact that democratic backsliding is not a well-defined or conceptualized process. For instance, Slater argues that, while democratic collapse is very rare in the $21^{\text {st }}$ century, many new democracies are experiencing "democratic careening," which he defines as "political instability sparked by intense conflict between partisan actors deploying competing visions of democratic accountability" (Slater, 2013, 731). In other words, 
Slater argues that many third wave states are vacillating between populist and oligarchic modes of politics as a result of conflicts between inclusivity (vertical) and constraints (horizontal) on government. Adopting a different terminology, Morlino identifies recurrent patterns of democratic "subversion," including attacks against the rule of law, decreased electoral accountability, constraints on political participation, insufficient political competition, short-comings regarding freedom and equality, and also a lack of elite responsiveness to citizens (Morlino, 2011).

When states transition to democracy, they fall somewhere along the continuum between autocracy and consolidated democracy. Over time, as democratic bodies are institutionalized, a state progresses toward consolidation. However, the path from authoritarianism to democratic consolidation is not always smooth. Sometimes, new democracies experience setbacks that undermine consolidation but do not result in autocracy: this is democratic backsliding. Figure 2.1 illustrates a theoretical case of democratic backsliding, showing how it is distinct from democratic consolidation and autocratic reversion.

Since the outcome of backsliding is an illiberal or diminished form of democracy, not autocracy, work on the quality and gradations of democracy, rather than the distinction between democracies and autocracies, is a relevant starting point for conceptualizing and measuring democratic backsliding (Geissel et al., 2016). In this project, democratic backsliding "denotes the state-led debilitation or elimination of any of the political institutions that sustain an existing democracy. Since the political institutions that sustain democracy are myriad ... the term embraces multiple processes" (Bermeo, 2016, 5). This general definition highlights several important components of democratic backsliding. 


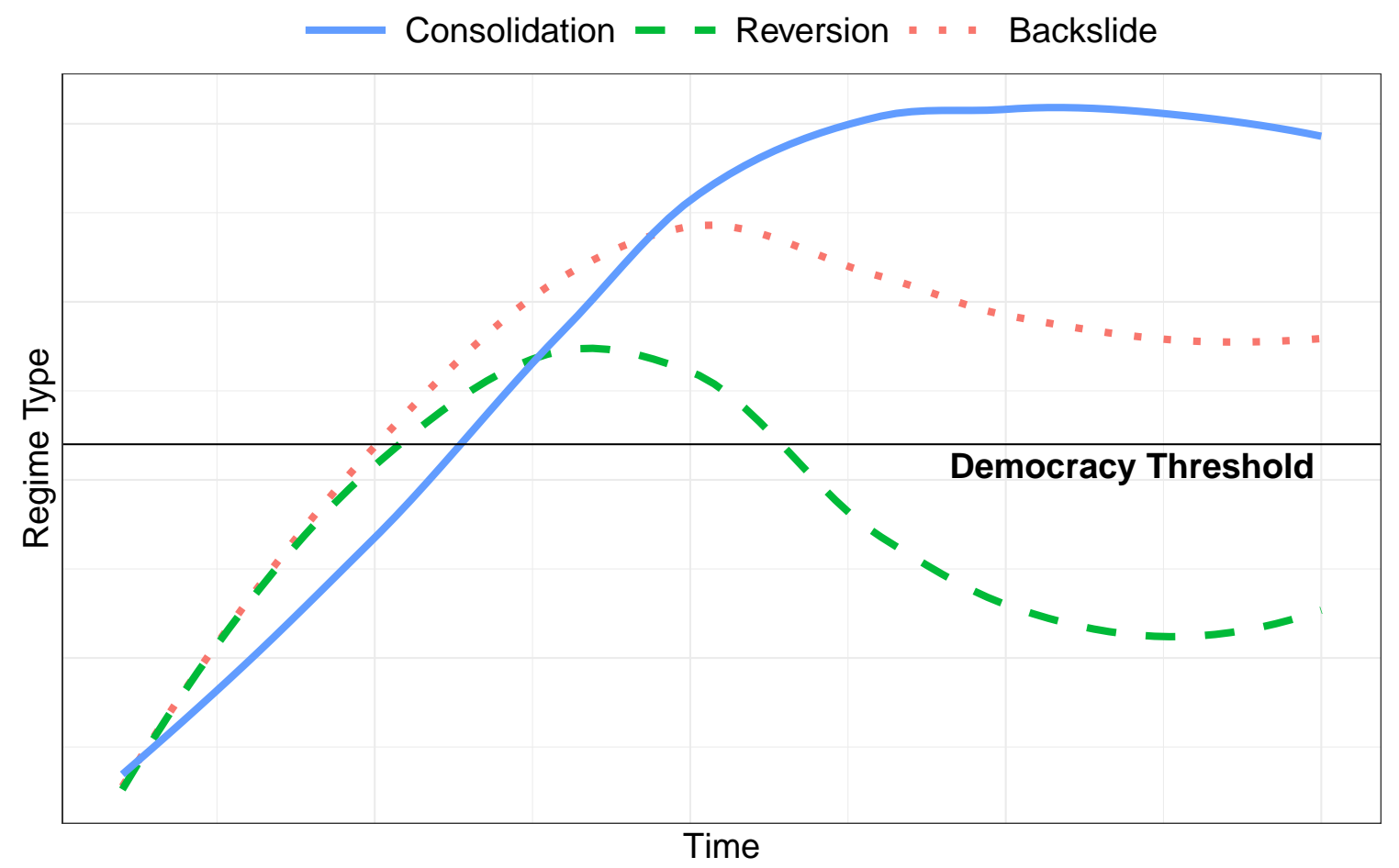

Figure 2.1: Democratic backsliding occurs when a state becomes less democratic without reverting to autocracy. 
First, democratic backsliding is a state- and often executive-led process, not a mass-based one, whereby elected leaders make legal institutional changes that weaken checks on their power while simultaneously eroding the strength of the opposition (Bermeo, 2016). The focus on the role of the executive in democratic backsliding is supported by Byman and Pollack, who find that the role of individual leaders in determining state outcomes is key, yet often under-theorized (Byman and Pollack, 2001). For example, recent democratic backsliding in some African countries has be attributed to ruling presidents and parties that often "flagrantly exploit the advantages of incumbency, abuse resources, and unleash physical intimidation on voters in the pursuit of victory" (Gyimah-Boadi, 2015, 103). These same elites have similarly been unwilling to pass reforms to limit their power or strengthen institutional checks. Executives' abilities to make these changes are amplified in scenarios where opposition parties, the legislature, or civil society lack the strength, organizational capacity, and societal roots necessary to oppose the executive. The result is a state with a powerful and often unchecked executive.

Second, democratic backsliding involves attacks by these elected officials against political institutions associated with democracy. Institutions that are targeted include the constitution, the rule of law, civil and minority rights, the independence of the judiciary and the media, and the separation of power within government (Maeda, 2010; Bermeo, 2016). Many of these institutions can be categorized as components of constitutional liberalism (Zakaria, 1997), or what is often identified as the liberal aspect of western liberal democracy. The total dismantling of institutions that are minimally necessary for a state to be considered a democracy - in particular, open, 
free, and fair elections (Schumpeter, 1950) - would be beyond the scope of democratic backsliding; this would more closely resemble autocratic reversion. Thus, the outcome of democratic backsliding is an illiberal or diminished form of democracy, not autocracy. ${ }^{4}$ As suggested by the range of institutions that can be targeted by elected officials, the outcomes of democratic backsliding can look different from one case to the next.

One term that is often closely linked to discussions of democratic backsliding is illiberal democracy, which is effectively a state that maintains minimal democratic characteristics, yet aspects of constitutional liberalism are limited or eroded (Zakaria, 1997). In addition, discussions of backsliding often reference hybrid regimes. Broadly conceived, hybrid regimes, which first began to emerge in the 1960s, are ones that combine both democratic and autocratic institutions (Diamond, 2002). Defined this way, hybrid regimes could indeed be another descriptor for states that have undergone backsliding, provided that the procedural minimalist aspects of democracy are maintained.

Competitive authoritarianism is one type of hybrid regime that would fall under this general categorization. Competitive authoritarian regimes are ones where multiparty elections are relatively, or at least procedurally, free and fair, yet the electoral playing field is tilted in favor of the ruling party or incumbent. From the viewpoint of outsiders, elections themselves in competitive authoritarian regimes are more or less democratic, free, and fair (Levitsky and Way, 2010). In this way, competitive authoritarianism is one potential type or outcome of backsliding where a state has regressed

\footnotetext{
${ }^{4}$ Since democratic backsliding often results in an illiberal democracy, populism, which has been defined as a form of democratic illiberalism (Pappas, 2016), and populist parties with charismatic leaders are common characteristics of regimes that have experienced backsliding.
} 
primarily with respect to institutions directly impacting electoral competitiveness but short of direct electoral manipulation.

To summarize, democratic backsliding occurs when elected officials weaken or

erode institutional checks on executive power, the strength of the opposition, and other, often liberal aspects of democracy, such as institutions that guarantee civil liberties and minority rights. However, the minimal aspects of democracy - free and fair elections and mass participation in politics - are maintained. Therefore, the outcome of democratic backsliding is an illiberal or diminished form of democracy, but not autocracy.

\subsection{The Democratic Institutional Strength Index}

Similar to recent work on the quality of democracy (Geissel et al., 2016), the definition of democratic backsliding I propose above is characterized primarily by a focus on the institutional components of democracy, going beyond the electoral and participatory minimalist characteristics of democracy (Dahl, 1971); in particular, it involves state-led attacks against democratic institutions (short of eliminating free and fair elections) and institutions that act as a check on executive power. This is in line with the research discussed in Sections 2.1.1 and 2.1.2 that finds that strong institutions beyond free and fair elections, such as rule of law, independent judiciaries, state capacity, civil society, and institutionalized political party systems, help to sustain and strengthen new democracies (Blokker, 2013; Bugaric, 2015; Fortin, 2012; Gibler and Randazzo, 2011; Kapstein and Converse, 2008; Issacharoff, 2015; Putnam, 1993). Therefore, in constructing an indicator for democratic backsliding, I 
focus on measuring the relative strength of these institutions found to be critical for democratic quality and survival.

Some have criticized this institutional focus in debates on the quality of democracy, arguing that a full understanding of democratic quality requires looking at both the institutional opportunities for democracy and the ways in which citizens participate in these institutions (Mayne and Geissel, 2016). While their point is well-taken, especially in the realm of democratic quality, I argue that the citizen aspect is ancillary to democratic backsliding. The institutional opportunities, or lack thereof, available to citizens can be heavily influenced or altered by existing institutions. Thus, it is critical to focus specifically on these institutions when identifying cases of democratic backsliding since state-led manipulation of these institutions subsequently influences citizen participation in democracy. In this way, democratic backsliding may be better understood as a decline on a subcomponent of democracy - certain institutionsrather than a decline on the entire latent concept - democracy - which has both institutional and mass-based components. In other words, democratic backsliding can be thought of as a disease: it has specific indicators used to diagnose its occurrence, but the longer-term outcomes and the impact on citizens can vary from one case to the next. Therefore, it is important to focus on the indicators of democratic backsliding (the institutional component) rather than on the subsequent effects that the erosion of these institutions has on other aspects of democracy (such as mass participation and citizen involvement) when constructing a variable to capture backsliding.

Unfortunately, most existing measures of regime type distinguish between countries by focusing on those minimalist characteristics of democracy - free and fair elections coupled with mass participation in politics (Dahl, 1971) — yet do not capture 
the strength of other institutions that influence a democracy's quality and prospects for success. As such, commonly used indicators distinguish between autocracies and democracies by measuring whether or not states hold free and fair elections but cannot capture subtle differences among democracies that emerge due to backsliding. This is particularly the case for dichotomous measures; however, even widely used continuous indicators, such as Polity (Marshall et al., 2016) and Freedom House (Freedom House, 2016), have high measurement error at the extremes, making it difficult to distinguish between two relatively democratic states (Treier and Jackman, 2008). Furthermore, these commonly used variables capture both democratic and autocratic institutions. For example, Polity's checks on executive power variable measures both democratic checks on the executive, such as the legislature, but also autocratic ones, such as the military (Luhrmann et al., 2017), which are not relevant to democracies.

Therefore, I use a Bayesian latent variable approach to construct an index that measures the range of institutions that can be eroded or weakened in cases of backsliding. Latent variable models measure unobservable phenomena-such as democratic backsliding - using observable characteristics theoretically linked to the underlying concept. These models aggregate indicators of observed characteristics to form a single, continuous measure of the latent trait; each individual component of the index is weighted by its error variance, so more reliable indicators are more heavily weighted.

Specifically, I adopt the Bayesian latent variable approach that Pemstein et al. use to create their Unified Democracy Scores (UDS) (Pemstein et al., 2010). This measure is widely applied in the democracy literature; for example, Flores and Nooruddin use it to measure democratic progress and even democratic backsliding (Flores and Nooruddin, 2016). There are several benefits to this approach. First, this method 
minimizes the impact of coding errors inherent in any individual index of democracy. Furthermore, different indices of democracy tend to measure different aspects of the concept; thus, by combining them all into one measure, the researcher does not have to choose which of the existing indicators to use.

The Bayesian latent variable approach assumes that rater mistakes across different democracy indicators are non-systematic and random. Specifically, the approach assumes independent normal prior distributions for each latent trait of democracy and then estimates the model using Markov chain Monte Carlo (MCMC) (Johnson and Albert, 1999). This model estimates latent continuous indicators of democracy for each country-year in the dataset. The resulting indicators are based on the pattern of agreement between the component indicators, and each has a corresponding probability distribution so that the error of the measure can be evaluated.

The original UDS is calculated using 10 different indices of democracy up through the year $2000 .^{5}$ The authors later extended the data temporally to 2012 and incorporated three additional democracy indices. Even more recently, Marquez introduced an R package, QuickUDS, that uses Pemstein et al.'s model to incorporate additional democratic indices and further extend the UDS dataset temporally (Marquez, 2016; Pemstein et al., 2010).

The continuous UDS index is better equipped to measure subtle differences between similar regimes than many of its constituent indicators, including other continuous ones, such as Polity IV (Marshall et al., 2016) or Freedom House (Freedom

\footnotetext{
${ }^{5}$ The 10 measures of democracy included in Pemstein et al.'s measure were Arat (Arat, 1991), Bowman et al. (Bowman et al., 2005), Bollen (Bollen and Paxton, 2000), Freedom House (Freedom House, 2007), Hadenius (Hadenius, 1992), Przeworski et al. (Przeworski et al., 2000) (PACL), Polity IV (Marshall et al., 2016), the Polyarchy scale (Coppedge and Reinicke, 1991), Gasiorowski's (Gasiorowski, 1996) Political Regime Change (PRC) measure, and Vanhanen (Vanhanen, 2003).
} 
House, 2016). However, Pemstein et al. note that UDS "might be better described as measures of autocracy or authoritarianism. Since scholars are divided about what features make developed democracies more or less democratic than one another ... the UDS is unable to distinguish between these countries" (Pemstein et al., 2010, 440).

The inability of the UDS to distinguish between two relatively democratic states is likely due to the fact that most of the latent factors included in the models are based on minimalist definitions of democracy that seek to differentiate democracies from autocracies by focusing on elections and participation. Following Marquez and using the QuickUDS and mirt packages in R, I adapt the UDS to create a variable specifically constructed to measure subtle differences between different types of democracy and, more specifically, democratic backsliding (Marquez, 2017). Building on my definition of backsliding from above, which highlights the institutions linked to democratic success, as well as those often targeted by officials in cases of backsliding, the index I develop focuses on institutional rather than citizen components of democracy. I call this variable the DIS index.

Specifically, to create the DIS index, I combine indicators of checks on executive power, representative institutions, judicial independence, human and minority rights, media freedom, executive respect for the constitution, and electoral quality. These indicators are taken from a range of established sources, including Freedom House (Freedom House, 2016), the Varieties of Democracy (V-Dem) (Coppedge et al., 2018), and Polity (Marshall et al., 2016). Table 2.1 provides a full list of the institutions and indicator(s) I include in the model to create the DIS index. 
Table 2.1: Factors in the DIS Index Model

\begin{tabular}{|c|c|}
\hline Institutional Component & Indicator(s) \\
\hline Checks on executive power & Political Instability Task \\
& Force (Ulfelder, 2008); Legislative \\
& constraints index (V-Dem); \\
& Polity (Marshall et al., 2016). \\
\hline Representative institutions & Economist Intelligence Unit's Index of \\
& Democracy (Geissel et al., 2016); \\
& Party institutionalization index; Civil \\
& society participatory environment; \\
& Civil society consultation (Coppedge \\
& et al., 2018). \\
\hline Judicial independence & High court independence; low court \\
& independence (Coppedge et al., 2018). \\
\hline Human and minority rights & Freedom House; Bollen 2000 (Bollen \\
& and Paxton, 2000); Economist \\
& Intelligence Unit's Index of \\
& Democracy (Geissel et al., 2016); \\
& Private civil liberties index; Equality \\
& before the law and individual liberties \\
& index (Coppedge et al., 2018). \\
\hline Electoral integrity & Government censors media; Internet \\
& censorship; Government harasses \\
& journalists (Coppedge et al., 2018). \\
\hline Media freedom & Executive respects \\
& constitution (Coppedge et al., 2018). \\
\hline & Participation Enhanced Polity \\
& index (Coppedge et al., 2018). \\
\hline
\end{tabular}


As Figure 2.2 illustrates, the resulting DIS index is a continuous variable that ranges from -2.34 to 2.83, with higher values indicating higher levels of democracy. According to the model, the institutional indicators that account for the most variance in the DIS index are checks on executive power, judicial independence, electoral integrity, and the strength of the opposition, all of which are rated around 0.9. Civil society and respect for the constitution are relevant but are not weighted as heavily (weighted $0.75-0.8$ ).

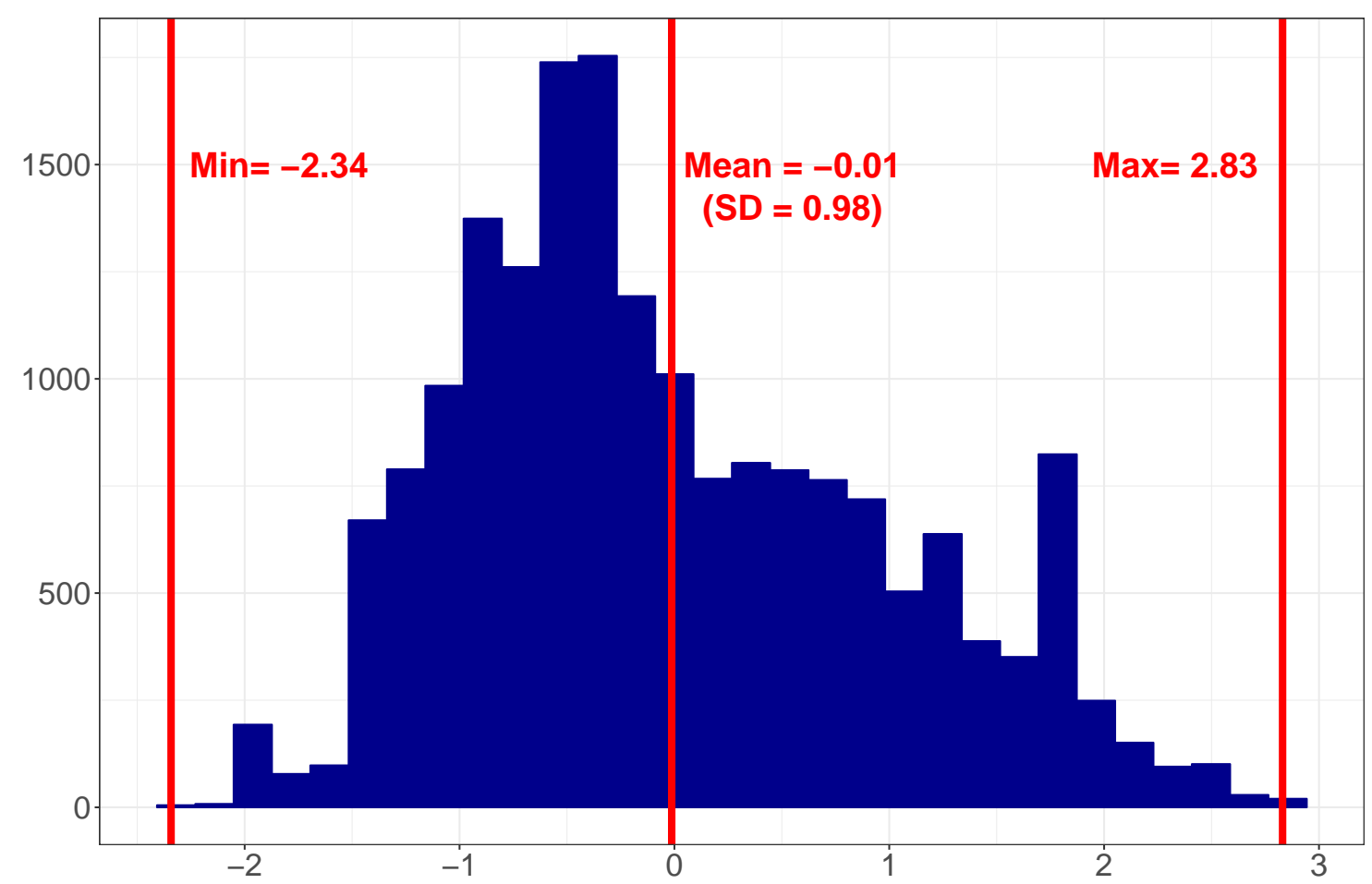

Figure 2.2: The Bayesian latent variable model that I use to combine the indicators from Table 2.1 creates the DIS index, a continuous variable designed specifically to capture democratic backsliding. 


\subsubsection{DIS Measurement Validation}

Although it draws on institutional indicators included in commonly used indicators of regime type, the DIS index is a more comprehensive measure of the range of institutions that can be targeted by elected officials in cases of backsliding. Table 2.2 outlines the institutional indicators included in the DIS index compared to other commonly used variables to measure regime type cross-nationally.

Table 2.2: The DIS Index Incorporates a Wider Range of Institutional Indicators Relevant to Backsliding When Compared to Other Commonly Used Regime Type Variables.

\begin{tabular}{|l|c|c|c|c|}
\hline & Polity & $\begin{array}{c}\text { Freedom } \\
\text { House }\end{array}$ & $\begin{array}{c}\text { Liberal } \\
\text { Democracy } \\
\text { Index } \\
\text { (V-Dem) }\end{array}$ & DIS Index \\
\hline \hline Checks on executive power & $\checkmark$ & $\checkmark$ & $\checkmark$ & $\checkmark$ \\
\hline Political opposition & $\checkmark$ & $\checkmark$ & $\checkmark$ & $\checkmark$ \\
\hline Electoral integrity & $\checkmark$ & $\checkmark$ & $\checkmark$ & $\checkmark$ \\
\hline Judicial independence & & $\checkmark$ & $\checkmark$ & $\checkmark$ \\
\hline Human and minority rights & & $\checkmark$ & $\checkmark$ & $\checkmark$ \\
\hline Media freedom & & $\checkmark$ & & $\checkmark$ \\
\hline \hline Political parties & & & & $\checkmark$ \\
\hline Civil society & & & & $\checkmark$ \\
\hline Constitution & & & & $\checkmark$ \\
\hline
\end{tabular}

The DIS index is nevertheless highly correlated with the following existing measures of democracy: Polity (0.89) (Marshall et al., 2016), Freedom House (0.94) (Freedom House, 2016), and the Liberal Democracy index from the V-Dem dataset (0.96) (Coppedge et al., 2018). Nevertheless, the DIS index picks up on more subtle changes in levels of democracy that are missed by other indicators, especially Polity and Freedom House. 
As Figure 2.3 illustrates, unlike Polity and Freedom House, the DIS index accurately captures recent cases of backsliding around the world.
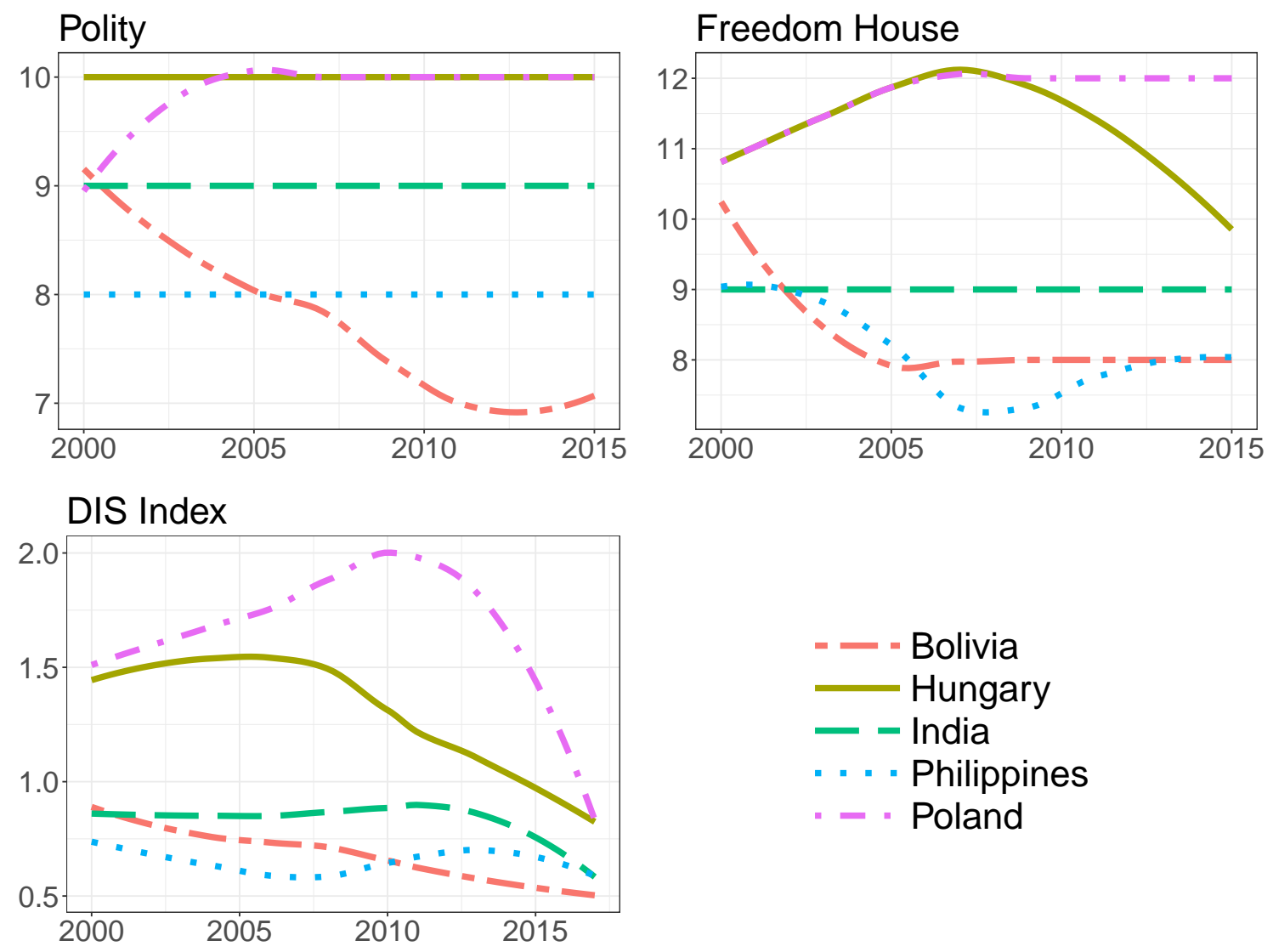

Figure 2.3: Unlike Polity and Freedom House, the DIS index picks up on prevalent cases of democratic backsliding.

Overall, the correlation between the Liberal Democracy index from the Varieties of Democracy dataset and the DIS is quite high; this is unsurprising since the V-Dem variable is created to measure different levels of democracy specifically. However, I argue that the DIS index provides some additional information relevant specifically 
to backsliding that is not captured by V-Dem. Looking at just the subset of countries the DIS index is specifically designed to measure - emerging democracies at risk of backsliding - the correlation between the DIS and the Liberal Democracy index drops from 0.96 to 0.88 . This suggests the DIS index is a valid measure of democracy, and even of liberal democracy, but also incorporates some institutional features specific to backsliding that other indicators overlook.

Figure 2.4 shows the distribution over time of the DIS index for the countries from Figure 2.3 over a longer time period. These plots further illustrate the DIS's ability to capture both subtle cases of backsliding and also more extreme reversions, as shown by Venezuela's plot. For example, Bolivia's DIS index begins to decrease slightly around 2010, capturing a weakened judiciary and decreased media freedom. In 2009, Bolivian President Evo Morales led the creation of a new constitution for Bolivia. This change was controversial and highly politically polarizing. After the constitution came into effect, the chief justice as well as four Supreme Court justices were either suspended or retired, and the entire Constitutional Tribunal resigned for political reasons, which resulted in a severely weakened judiciary. There were also attacks against journalists (Human Rights Watch, 2010). Similarly, India's DIS index begins to decrease around 2013, a time when international observers such as Human Rights Watch began to report India's failure to protect civil and human rights (Human Rights Watch, 2013), and the year before current Prime Minister Modi first came to power.

Hungary and Poland are two other recent yet widely cited cases of democratic backsliding. Based on the Polity indicator alone, it would appear that Hungary and Poland have not undergone democratic backsliding. In contrast, the DIS index 
captures this phenomenon in a way completely missed by Polity. Hungary's DIS index begins to decrease around 2008, which marks the Hungarian Socialist party's corruption scandal, shattering the party's credibility (Herman, 2015). Hungary's DIS continues to plummet after 2010, at which time Orbán's Fidesz party gained an absolute majority in parliament and began attacks against judicial independence and media freedom and, in 2012, completely re-wrote the constitution. Similarly, Poland's DIS score begins to decrease around 2015, at which time the populist, farright Law and Justice (PiS) party came to power and began concerted attacks against the constitutional court and, more recently, the judiciary as a whole.

The DIS index also measures more extreme attacks against democracy, such as with Venezuela beginning around 2000. In 1998, Venezuela's Hugo Chavez adopted a constitution that strengthened the powers of the president while simultaneously weakening the legislature and judiciary, all without abandoning contested elections. More recently, Maduro has taken extreme steps to sideline the opposition in Venezuela.

\subsection{Next Steps}

This chapter began by developing a theoretically based definition of democratic backsliding, going beyond the minimalist conceptualization of democracy, to focus in particular on the range of democratic institutions that enhance both the quality and success of democracies, but that can also be targeted by elected officials in cases of backsliding. These institutions simultaneously act as a check on executive power, guarantee civil liberties and human rights, and in many cases also serve representative functions. Building on this conceptualization of backsliding as the erosion of one or more of these democratic institutions by elected officials, this chapter then develops 


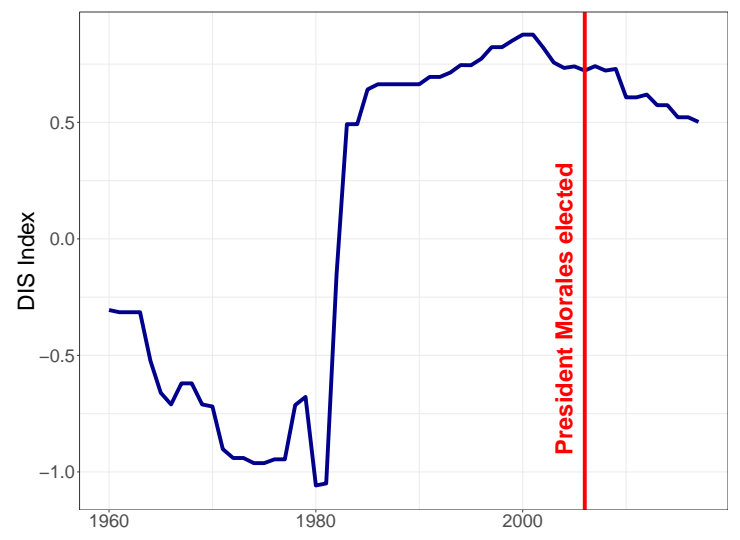

(a) Bolivia

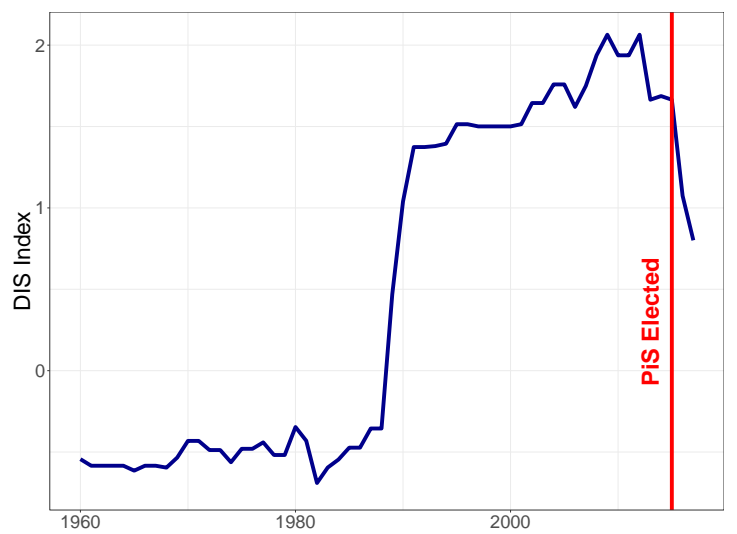

(c) Poland

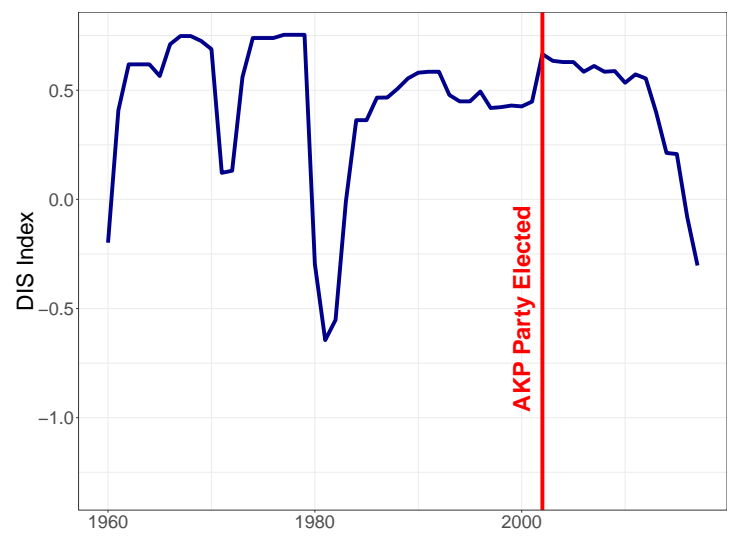

(e) Turkey

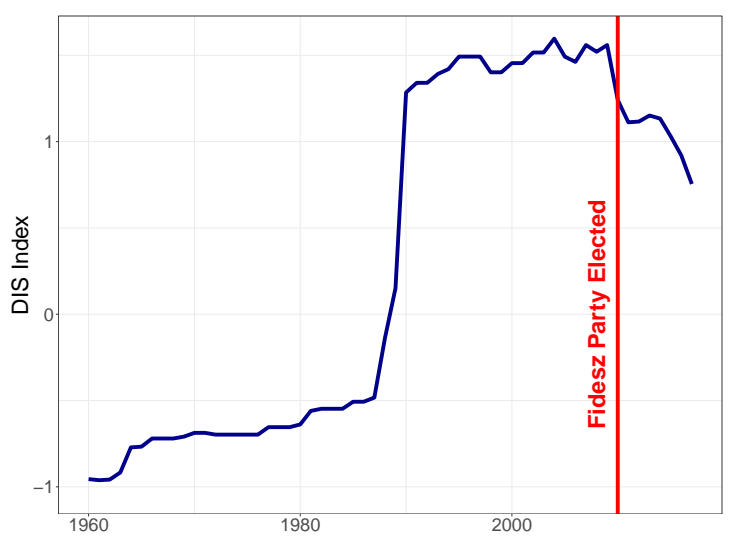

(b) Hungary

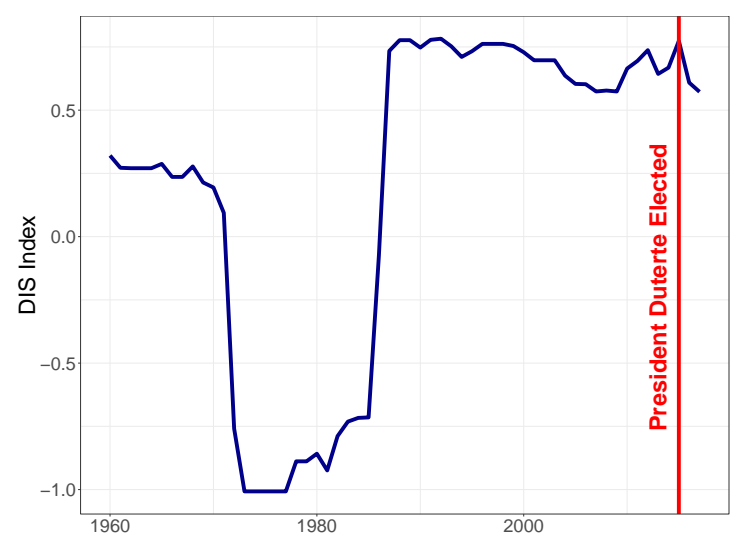

(d) Philippines

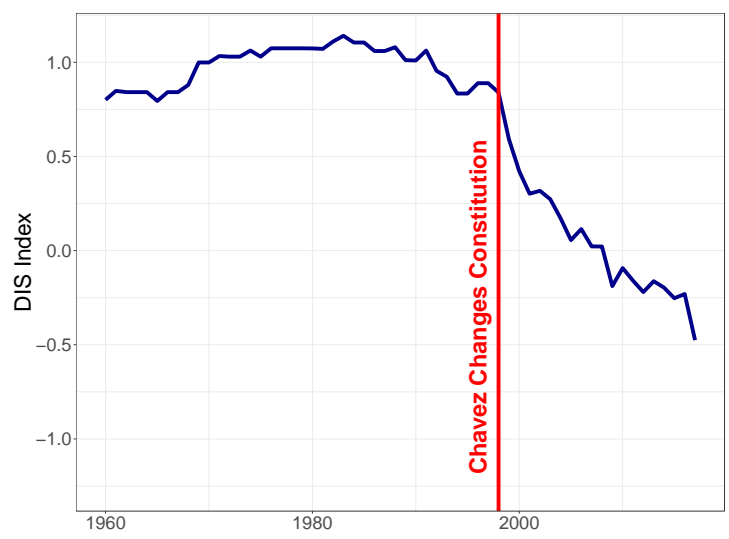

(f) Venezuela

Figure 2.4: DIS index for select countries. 
a Bayesian latent variable-based indicator to measure backsliding - the DIS indexwhich combines indicators of the strength of a range of democratic institutions. Unlike most existing indicators of regime type, which tend to emphasize minimalist aspects of democracy, or are designed to measure both democratic and autocratic institutions, this variable is able to pick up on subtle yet meaningful erosions in levels of democracy and thus differences between democracies that result from backsliding.

However, existing research on democratic backsliding is still quite limited, despite the fact that this is an increasingly common phenomenon. In addition to previously lacking a variable designed specifically to capture backsliding, scholarship on this topic has yet to develop and systematically test theories about the sources of backsliding. To the extent that it has been studied, authors have focused primarily on domestic-level factors linked to backsliding and have studied it on a case-by-case basis. However, given the level of international involvement in new democracies' initial transitions to democracy, I argue it is imperative to also consider how international actors may be contributing to these regime outcomes. In the next chapter, I propose a theory linking democracy promoting IOs to democratic backsliding in new democracies. The remainder of the dissertation then combines the DIS index with original and existing panel data to systematically assess the extent to which international factors have inadvertently contributed to democratic backsliding in new democracies around the world. 


\section{Chapter 3: A Theory of International Organizations and Democratic Backsliding}

The previous chapter proposed a theoretically based definition of democratic backsliding and, building on this definition, used a Bayesian latent variable approach to construct an original, cross-national indicator of backsliding: the Democratic Institutional Strength (DIS) index. However, democratic backsliding is a relatively new phenomenon empirically, and its causes are not fully understood. To the extent that backsliding has been researched, scholars have focused in particular on domestic-level sources of these attacks against democratic institutions. While domestic characteristics are undoubtedly a critical component of the story, they are insufficient to explain these emerging trends. This is because, over the past several decades, international actors have played an unprecedented role in transitions to democracy throughout the developing world. Despite research that finds international actors have an overall positive impact on democratic outcomes, these international interventions are in many cases in the same states now showing evidence of backsliding.

What explains democratic backsliding in an age of unparalleled international support for democracy? Democratic backsliding occurs when elected officials weaken or erode democratic institutions and results in an illiberal or diminished form of democracy, rather than autocracy. Although research has identified case-specific causes 
of backsliding (Berman, 2016; Hanley and Sikk, 2016; Hernandez and Kriesi, 2016; Krastev, 2016; Rupnik, 2016), no systematic theories of this phenomenon exist (Waldner and Lust, 2018). On the international side, authors have critiqued democracy assistance and suggested it can even have deleterious effects (Bush, 2015; Henderson, 2003; Savage, 2017; Wedel, 2001), while others have shown how regional powers may engage in autocracy promotion (Finkel and Brudny, 2012). However, few have investigated the role of IOs in particular and how they might be contributing to these illiberal trends.

Drawing on institutional theories of democracy, this chapter argues that although IOs often serve as a critical impetus for states to transition to democracy, they also unintentionally sow the seeds for future democratic erosion and backsliding. They do this both indirectly by failing to support key democratic institutions outside of elections and also more directly by stunting the development of these critical democratic institutions. Democratic success is contingent upon the strength of institutions that organize mass participation in politics, aggregate societal interests, and enable the state to both govern effectively and, critically, limit itself (Huntington, 1968). These institutions include political parties, strong legislatures, independent judiciaries, and general state capacity. IOs commonly associated with democracy promotion focus predominantly on elites and elections but neglect to support other democratic institutions. This narrow focus makes new democracies more susceptible to democratic backsliding.

In addition to indirectly contributing to backsliding by neglecting to support important democratic institutions, IOs also more directly alter the domestic institutional 
landscape in new democracies in two ways. First, as a by-product of how they interact with states, IOs increase relative executive power. Democracy promotion by IOs focuses in particular on elite incentives and resources, and executives serve as the main intermediaries between their states and IOs. This shifts the domestic balance of power in favor of executives.

Second, IO conditionality and membership requirements limit states' economic and other domestic policy options; this impedes institutional development. Political parties and legislatures in new democracies become institutionalized by advocating and debating meaningful policy alternatives. However, when external requirements limit policy options, these institutions remain underdeveloped. Diminished policy options also constrain leaders' ability to govern effectively and provide public goods. Unable to appeal to voters based on records of effective governance or policy alternatives, executives instead manipulate or erode democratic institutions - such as the constitution, judicial independence, and media freedom - to maintain power. This is easier when horizontal institutions of accountability, such as parties and legislatures, are weak. In these ways, IO-induced institutional shifts make democratic backsliding more likely.

This chapter develops a theoretical framework linking membership in democratically relevant international organizations (IOs) to backsliding in new democracies around the world, preceding as follows. The next section gives an overview of existing theories of backsliding, which are still developing and focus primarily on domesticlevel sources of this emerging phenomenon. However, since many of the states that are backsliding were heavily influenced by international factors during their transitions to democracy, the next section of the chapter outlines existing work on international 
sources of democratization. Because IOs are often at the core of studies of democracy promotion, the following section outlines the literature and related positive expectations about the impact of IOs on democratic development. Next, I propose an original theory for why IOs may not be as effective at promoting democracy as existing work suggests, outlining one indirect and two direct proposed mechanisms linking IO membership to democratic backsliding in new democracies. After outlining the theory and its related empirical expectations, the subsequent sections discuss the scope conditions of the theory and possible alternative explanations. Finally, the chapter concludes with a discussion of the relevant counterfactual for this theory and a preview of the research design that will be used in the following chapters.

\subsection{Existing Theories of Democratic Backsliding}

Despite becoming an increasingly common phenomenon over time, studies of democratic backsliding, and particularly of its causes, "remain inchoate" (Waldner and Lust, 2018). What few studies of democratic backsliding specifically that do exist tend to focus predominantly on domestic-level causes of this regime outcome. Highlighting the central role that executives play in triggering backsliding, certain scholars find that power-seeking presidents are better able to initiate backsliding in cases where their power is unconstrained by institutional safeguards or oppositional political forces (Fish, 2001; Van De Walle, 2003). These findings are reinforced by studies that suggest the collapse of social-democratic and center-left parties (Berman, 2016; Fomina and Kucharczyk, 2016; Krastev, 2016; Innes, 2014), coupled with the rise of more extreme parties (Lochocki, 2016), has also contributed to recent democratic erosions. 
Relatedly, Mainwaring and Pérez-Liñán find find that actors (presidents, parties, militaries), not structures, determine regime outcomes (Mainwaring and Pérez-Liñán, 2013). In particular, actors' normative preferences about democracy and dictatorship, their modernization or radicalization policy preferences, and international political influences, both direct and indirect, exercised through external actors, all influence regime outcomes.

In addition to explanations based on political actors and institutions, others have attributed backsliding to structural and cultural factors at the domestic level. Economic factors are one prominent explanation. Scholars have focused on economic sources of democratic erosion, such as recession in general (Svolik, 2008), and the Eurozone crisis in Europe specifically (Sánchez-Cuenca, 2017). Authors have also highlighted the rise of populist parties, which have been particularly successful at exploiting anti-immigrant and, in Europe specifically, anti-EU sentiments among voters to gain power and challenge existing democratic structures in their respective countries (Krastev, 2016; Reynié, 2016; Rupnik, 2016).

Although individual actor, institutional, and structural domestic factors are all undoubtedly important sources of backsliding, I argue that this heavily domestic focus of nascent theories of backsliding is insufficient, particularly in the case of new democracies. In these countries, transitions to democracy, and the accompanying formation and institutionalization of domestic democratic organizations, were heavily influenced by international actors. Indeed, this international influence is often cited as one of the defining characteristics of the third wave of democracy, which began following the Carnation Revolution in Portugal in 1974 (Huntington, 1991). Third wave democracies have also been influenced by broad structural factors to a much 
greater extent than states that comprised the first and second waves of democracy (Haggard and Kaufman, 2016).

The next section outlines existing research on international factors and democracy. Although this literature is extensive, the general consensus is that international actors have a net positive impact on democratic outcomes at the domestic level. However, there are a few important exceptions. Several authors have critiqued democracy assistance and suggested it can even have deleterious effects (Bush, 2015; Henderson, 2003; Savage, 2017; Wedel, 2001), while others have shown how regional powers may engage in autocracy promotion (Finkel and Brudny, 2012; Whitehead, 2015). Nevertheless, no studies have explicitly hypothesized or tested the extent to which international actors may unintentionally create conditions that make democratic backsliding more likely at the domestic level. This is despite the fact that

As with democracy promotion more generally ... shadows are falling over the international enterprise. The expectation of strong diffusion processes was associated with a particular moment in world history: the collapse of an authoritarian superpower, the dissolution of its empire, a brief moment of unchallenged American supremacy, and a strong belief in the combined power of economic interdependence, international institutions, and democracy (Haggard and Kaufman, 2016, 137)

Therefore, after outlining existing findings on the relationship between international factors and democracy, I propose a link between international actors - and IOs in particular — as another potential source of democratic backsliding in new democracies.

\subsection{The International Side of Democracy}

Scholars have proposed a range of mechanisms linking international actors to domestic-level regime outcomes, considering both structural and more proximate, 
regional-level influences. For example, at the system-level, Gunitsky finds evidence of "hegemonic shocks" whereby changes in the relative distribution of power among leading states in the international system can create opportunities for regime imposition that lead to waves of domestic political and institutional shifts. The nature of the domestic reforms is conditioned on the political identity of the emerging hegemon (Gunitsky, 2014). Boix, too, finds that systemic changes condition the extent to which development leads to democracy (Boix, 2011).

In addition to these system-level sources of democracy (or regime change more broadly), other scholars have focused in particular on the diffusion of regime types, often at the regional rather than global level. Regime type diffusion can occur via four distinct mechanisms: coercion, competition, learning, and emulation (Simmons et al., 2006). Gleditsch and Ward, for example, attempt to explain the regional and temporal clustering of democratic transitions, arguing that democracy spreads across borders via soft coercion: states become less afraid of democracy when reference countries become democratic (Gleditsch and Ward, 2006). Similarly, Beissinger argues that democratic revolutions are not independent events, but rather "modular phenomena" that are influenced and encouraged by revolutions in other countries. Thus, the influence of examples from abroad can act as a substitute for domestic structural factors that would otherwise preclude a revolution within a given state (Beissinger, 2007).

Similar to diffusion, Levitsky and Way theorize that new democracies' levels of linkage to and leverage from western international actors influence their prospects of democratizing (Levitsky and Way, 2010). In this framework, linkage is in many ways similar to diffusion: it simply refers to the density of international interactions of various types. Leverage, on the other hand, is a more purposeful, actor-oriented process. States have high leverage over other states when: i) the addressed state 
is economically and/or militarily weak or dependent, ii) the leveraging state does not have significant interests apart from achieving political change in the addressed country, and iii) when other regional powers do not play a major role in the interaction between the two relevant countries (Burnell and Schlumberger, 2010). According to Levitsky and Way, democratization is more likely when states have high linkages with western democracies and also when these western actors have significant leverage over democratizing states (Levitsky and Way, 2010).

Related to this idea of external linkages and leverage, Morlino proposes "external anchoring" as a means of conceptualizing this international-domestic interaction, arguing that conditionality and socialization from IOs are the most promising mechanisms for understanding this external-internal relationship. First, IOs can use either negative or positive conditionality to influence regime outcomes. Conditionality relies on actor-based, rational bargaining and utilitarian calculations by domestic actors about whether or not to comply. Furthermore, for conditionality to be effective, a state must have both the institutional and administrative capacity to effectively implement changes and also domestic agents who are committed to change (Morlino, 2011).

\subsection{International Organizations and Democracy}

International organizations (IOs) are often at the forefront of studies on the international sources of democracy. Research on these organizations is largely positive, finding they can support democratic transitions and consolidation among their member states. IOs achieve these objectives primarily by focusing on domestic executives' behavior and incentives as well as by providing election-related assistance (Pevehouse, 2005; Donno, 2013a; Genna and Hiroi, 2014; Poast and Urpelainen, 2018). Although most of the literature on IOs and democracy is positive, several scholars are more 
apprehensive. Ulfelder, for example, finds that state participation in major IOs has little effect on whether or not a state attempts or sustains democracy (Ulfelder, 2008), and Reiter argues that NATO has not and cannot advance democracy in southern and eastern Europe (Reiter, 2001). Relatedly, studies have found that foreign aid for democracy in developing states can adversely effect political accountability and representative institutions by reducing government dependency on tax revenue (Eubank, 2012).

\subsubsection{Why Do IOs Promote Democracy?}

Democracy promotion by IOs is driven by a desire to promote development via good governance. Although it takes a number of forms, the main tools of international democracy promotion include election monitoring, democracy aid, and conditionality (Donno, 2013b). Democracy promotion by IOs is best understood by considering the interests and rational calculations of the member states of an international organization (Keohane, 1984; Moravcsik, 1998); IOs promote democracy when the member states consider it to be in their interest to do so. Specifically, democratic members of IOs, and especially democratic members of IOs with a regional focus, support democracy promotion because it serves their economic and geopolitical interests and also increases domestic legitimacy. ${ }^{6}$ Indeed, "if scholarly research concerning the economic and political advantages of democracies is correct, then one would expect democracies to rationally desire to have more democracies in the world" (Pevehouse, 2005, 18). These states choose to promote democracy through IOs, rather than unilaterally, since IOs can both reduce the transaction costs associated with democracy promotion, for example by providing information about and facilitating the monitoring of

\footnotetext{
${ }^{6}$ There is no reason to expect non-democratic members of an IO to support democracy promotion; therefore, my theory is focused on democratic members of IOs only. Any references to member states throughout the chapter is to democratic states.
} 
democracy-building efforts in target states, and also are able to provide incentives for target states that individual countries alone cannot.

Economic considerations also in part motivate democracy promotion by IOs. Many regional organizations were initially created to facilitate economic cooperation between states. Increased economic cooperation and interdependence is viewed as a means toward security: economic integration makes conflict between states less likely. This thought drove the founding of the European Coal and Steel Community (ECSC), the precursor to the European Union (EU), in the wake of World War 2. Although today the EU has an extensive political component, the ECSC, and the later European Economic Community (EEC), were both primarily economic organizations, and the EU today, with its common market and shared currency, maintains this primarily economic focus. A number of other regional organizations, such as Mercosur in South America, are primarily economic organizations with free trade areas.

However, the advantages of economic interdependence are conditional on individual member states' regime types. Research finds that democracies are more likely to prefer trade with other democracies (Bliss and Russett, 1998; Mansfield et al., 2000; Morrow et al., 1998; Polachek, 1997), and regime type has been found to have important impacts on economic issues (Schultz and Weingast, 2003), such as market sentiments and perceptions of risk for international investors (Gray, 2009). Since this is the case, democracies in IOs prefer that the other members of their organization, and, more broadly, that other states in their regions, be democracies.

In addition to the economic advantages of being part of an IO composed primarily of democracies and having democratic neighbors, there are also geopolitical considerations that drive democracy promotion. Democracies are theorized to cooperate with one another (Mansfield et al., 2002) and ally with one another (Simon and Gartzke, 1996; Siverson and Emmons, 1991) and are also less likely to go to war with one 
another (Russett, 1993). In other words, geopolitically, democracy is viewed as desirable since it increases regional stability (Russett, 1994). Indeed, one of the principle reasons why existing members of the EU initially supported and promoted enlargement to Central and Eastern Europe was because they considered enlargement to be in their long-term economic (expansion of the internal market) and geopolitical (increased stability in Central and Eastern Europe) interests (Moravcsik and Vachudova, 2003). Finally, states use IOs to promote democracy as a means of increasing their own domestic and external legitimacy (Pevehouse, 2005; Pridham, 1995; Whitehead, 1996).

Democracies have a number of economic, geopolitical, and legitimacy-based incentives to promote democracy, especially in states with which they interact frequently or share a geographical neighborhood. Why do these states use IOs to promote democracy? First, most states lack the resources necessary to promote democracy unilaterally; this lack of outside options makes operating through IOs appealing. However, even great powers, which often do have the ability to unilaterally promote democracy, still choose to use IOs instead. This is because IOs legitimate and lend credibility to situations that would otherwise lack it (Stone, 2011). Indeed, "multilateral efforts will often be a favored mechanism of democracies since it minimizes the perception on the part of actors within the target state of direct violations of sovereignty" (Pevehouse, 2005, 19); this is a particularly relevant concern for great powers, such as the United States, that have been criticized in the past for violating states' sovereignty, especially during the Cold War period.

Another advantage of working through an IO is that membership in these organizations provides incentives for states to comply with democratic conditions that individual states alone cannot provide. Benefits of membership in IOs often include economic benefits, such as membership in free trade areas or foreign aid reserved 
exclusively for democracies. Furthermore, since IOs often have already created institutions charged specifically with democracy promotion, acting through IOs is less costly for states than trying to promote democracy unilaterally.

\subsubsection{Which IOs Promote Democracy?}

Certain types of IOs in particular are associated with democracy promotion. First, the literature has identified IOs explicitly committed to promoting and supporting democracy; this includes any organization that references support for democracy, human rights, or rule of law in their charter or other official documents (von Borzyskowski and Vabulas, 2018). However, there is important variation with respect to both the functionality and levels of institutionalization among these organizations.

Poast and Urpelainen find that increased democratization among new democracies is most strongly associated with the formation of political and economic organizations, which help new democratic governments both provide public goods and also bolster elections and other developing democratic institutions (Poast and Urpelainen, 2018). This suggests that political and economic, in addition to democratically committed, IOs should be particularly likely to influence regime outcomes.

IOs also vary with respect to their capacity to influence state behavior. At one extreme are minimalist IOs, which either exist exclusively on paper or have minimal organizational structures. Minimalist IOs are characterized by limited procedural rules and non-binding decisions that cannot influence state actions; enforcement and implementation of decisions is optional. At the intermediate level are structured IOs. Structured IOs have formal voting rules and codified procedures for member state interactions, specified organizational operations, a bureaucracy for carrying out decisions, and can make binding decisions. If they do not have a bureaucracy, there is some concrete administrative body that operates independently of member states. 
Finally, at the highest level of institutionalization are interventionist IOs, which have clear mechanisms to coerce or influence state behavior. These organizations have codified rules and procedures that govern relations between the executive, legislative, and judicial structures of the organization. Interventionist IOs can sanction states by withholding economic benefits or intervening directly in conflicts (Boehmer et al., 2004). Furthermore, with their ability to influence state behavior, interventionist IOs are more likely than minimalist and structured ones to meaningfully influence states' democratic institutions.

\subsection{Theoretical Framework: Linking International Organiza- tions and Democratic Backsliding}

Although IOs have been linked to democratic outcomes in their member states, there are reasons to believe that these impacts are only short-term and superficial and that IOs are more limited in their ability to promote long-term democratic quality and survival. Building on existing research, I argue IO membership can make democratic backsliding more likely in new democracies. This section consists of three parts. First, I discuss the indirect mechanism I propose linking IOs to backsliding. Specifically, I argue that the IOs most commonly associated with democracy promotion and progress, with their emphasis on elites and elections, fail to support the development of other critical democratic institutions. This creates conditions for future democratic erosion. IOs also more directly contribute to backsliding in two additional ways: by simultaneously increasing executive power and constraining the domestic policy space, which further impedes institutional development. The resulting combination of factors - a strong executive surrounded by weak institutions unable to check the executive's power - increases a state's probability of backsliding. I develop these direct mechanisms in the second and third parts of this section. 


\subsubsection{Indirect Mechanism: Neglecting Important Democratic Institutions}

Research in international relations links IO membership to a range of outcomes. Broadly, scholars find IO membership influences state behavior through socialization and conditionality (Kelley, 2004) and regularizes expectations about a state's future behavior by locking in domestic institutional changes and tying the government's hands (Axelrod, 1981; Gray, 2009; Keohane, 1984; Koremenos et al., 2001; Morrow, 1994). IO membership is also linked to higher government credibility (Dreher and Voigt, 2011), a reduced likelihood of conflict between states (Oneal and Russett, 1999), and an acceptance of regional or global norms (Checkel, 2005; Schimmelfennig, 2005). Finally, scholars find membership increases a state's likelihood of democratic transitions and consolidation (Donno, 2013a; Mansfield and Pevehouse, 2008; Nygard, 2017; Pevehouse, 2005; Poast and Urpelainen, 2018).

The literature linking membership in IOs - and in democratically committed, political and economic, and interventionist IOs in particular - to democracy tends to focus on the impact of these organizations on elections and executives in new democracies. Because executives serve as the main intermediaries between states and IOs (Moravcsik, 1994), democracy promotion by these organizations heavily emphasizes executives. Scholars find IOs promote and support democracy via material incentives that induce incumbents to undertake institutional reforms (Donno, 2013a). IOs use economic sanctions to disincentivize anti-democratic behavior and provide economic assistance to member states, which helps domestic leaders deter rebellions. In addition, IOs socialize rulers into accepting democracy (Genna and Hiroi, 2014), and influence their international status, either by helping them build a reputation for being committed to democracy (Poast and Urpelainen, 2018) or by shaming those who violate electoral norms (Donno, 2013a). Finally, IOs serve as commitment devices, 
helping democratic leaders gain the support of domestic elites and deterring political losers from overthrowing the new regime (Pevehouse, 2005).

In addition to elites, research on IOs and democracy also emphasizes elections. Following the end of the Cold War, approaches to international democracy promotion developed according to the transitions paradigm, which assumes any state moving away from authoritarianism is transitioning toward democracy, stresses the importance of elections as the first step toward eventual democratic consolidation, and largely disregards the impact of structural and institutional factors on a state's democratic prospects (O'Donnell and Schmitter, 1986). As a result, democracy promotion heavily emphasizes free and fair elections, viewing these as a critical pre-requisite for long-term democratic success (Schedler, 2002; Howard and Roessler, 2006; Hadenius and Teorell, 2007), yet has provided much less support for other democratic institutions, such as political parties (Carothers, 2002).

This emphasis on elections has driven IOs and other international democracy advocates to promote elections even in countries that lack other democratic institutions. In fact, electoral assistance is the most common type of democracy assistance from IOs. Initially, this was primarily in the form of election monitoring, but the focus has shifted to a greater emphasis on improving election laws, updating voter registries, and other election-related logistics (Donno, 2013a; Johnstone and Snyder, 2016; Poast and Urpelainen, 2018).

The focus on executives and elections is evidenced by IOs' democracy promoting strategies. For example, the Organization of American States (OAS) is largely limited to election monitoring and to offering training and consultation to new democratic leaders (Cooper and Legler, 2006). The EU's elite bias has also been noted. EU democracy promotion in post-communist Central and Eastern European countries favors executives and their bureaucracies over other democratic institutions and is 
undertaken in a top-down manner, without support from political groups or civil society (Bugaric, 2015; Grabbe, 2001; Pridham, 2007).

Although elections and executive compliance with democratic institutions are important for democracy (Dahl, 1971; Huntington, 1991; Przeworski et al., 2000), they are insufficient to guarantee democratic quality and survival. The limits of election monitoring have been identified (Hyde, 2011; Simpser and Donno, 2012), and elections alone are insufficient to promote ongoing democratic progress (Flores and Nooruddin, 2016). Institutionalist theories of democracy argue organizations for managing mass participation and performing key representative functions are equally if not more important (Herman, 2015; Almond and Verba, 1963; Mainwaring, 1999; GrzymalaBusse, 2007; O’Donnell and Schmitter, 1986). Such institutions include political parties, which aggregate mass interests and serve as intermediaries between citizens and the state (Huntington, 1968; Carothers, 2006), and civil society organizations. Horizontal checks on government power are also critical as are those that constrain the power of political winners; these institutions "consistently enhance democratic stability, regardless of political context" (Graham et al., 2017, 2). This includes independent judiciaries, which can block executives seeking to increase their power (Gibler and Randazzo, 2011), and intra-governmental checks and balances, such as legislatures (Graham et al., 2017). IOs devote much less attention to promoting and developing these other democratic institutions critical to sustaining a new democracy.

To summarize, I argue that IOs most commonly associated with democracy unintentionally make democratic backsliding more likely by focusing predominantly on elites and elections at the expense of other democratic institutions. Therefore, I predict the following:

1. Membership in democratically committed, political and economic, and interventionist international organizations will be associated with subsequent backsliding in new democracies. 
IOs also more directly contribute to backsliding in two interrelated ways: by increasing relative executive power and constraining the domestic policy space, which further impedes institutional development in new democracies.

\subsubsection{Direct Mechanism 1: Increasing Executive Power}

IOs promote democracy by altering elites' incentives to comply with or maintain democratic institutions (Donno, 2013a; Genna and Hiroi, 2014; Pevehouse, 2005; Poast and Urpelainen, 2018) or by providing technical assistance to leaders in new democracies (Poast and Urpelainen, 2018). Authors that approach this topic primarily from the domestic point of view also emphasize the importance of domestic elites, and especially executives, as the critical intermediaries or "gatekeepers" between international actors and their countries (Moravcsik, 1994; Tolstrup, 2013; Yilmaz, 2002). As such, IO membership can increase executive power relative to other domestic institutions.

I argue IOs provide both incentives and opportunities for executives, who are rational actors concerned with maintaining office, to manipulate institutions to their advantage; this, in turn, makes backsliding more likely. The intense emphasis international actors place on elections has resulted in free and fair elections becoming a condition for receiving international material benefits (Hyde, 2011). As such, executives have incentives to refrain from directly manipulating elections on election day to stay in office; instead, they resort to more subtle tactics to maintain power, such as "strategically manipulating" elections by interfering with non-electoral institutions (Beaulieu and Hyde, 2009).

IOs facilitate this by increasing executives' power relative to other domestic institutions in several ways. First, membership in IOs redistributes power between state executives, on one hand, and other government institutions and society, on the other; 
this power shift tends to favor the executive. As members of IOs, executives either serve as their state's representative within the organization, or they have the power to directly appoint (unelected) representatives. As a result, international cooperation increases executive power over domestic policy and gives executives the ability to strongly influence or even ratify international decisions; this is often done "with relatively little ministerial, legislative, judicial, or public oversight" (Moravcsik, 1994, 7).

Second, IOs provide financial resources. The EU, the OAS, and the Economic Community of West African States are all examples of organizations that provide development- or democracy-related financial assistance to their candidate and member states. This financial assistance, which is often received, controlled, and allocated by executives, increases recipient governments' ability to use patronage to maintain power and garner electoral support (Ahmed, 2012; Jablonski, 2014). Indeed, there is mounting evidence the Hungarian Prime Minister, who has been at the forefront of Hungary's illiberal turn, has strengthened his power by allocating EU development and infrastructure funds to members of his inner political circle (Rankin, 2018).

Finally, in certain IOs, membership conditionality requires countries to develop an extensive bureaucracy to facilitate the state's preparations for membership and participation in the IO. To this end, IOs offer technical assistance to potential member states for constructing regulatory, economic, and other bureaucratic offices. A strong bureaucracy and state capable of guaranteeing the provision of basic public goods, such as rule of law and the regulation of economic transactions, is important for democracy (Fortin, 2012; Grzymala-Busse, 2007). However, the bureaucracy is also unaccountable to voters and is often closely linked to, and thus serves as an additional resource for, executives. 
The more IOs a state is in, the more opportunities executives have to receive financial resources and make international-level decisions. However, the extent to which IO membership increases executive power depends on the IO's type. While minimalist IOs have more limited effects on domestic processes, interventionist ones provide mechanisms for altering outcomes within member states and are more likely to have structures that increase executives' international decision-making powers. As such, membership in more institutionalized IOs is particularly likely to increase executive power by creating venues for executives to influence domestic policies. This is especially the case in political and economic IOs, which focus on and given executives power over substantive policy issues. Drawing on these factors, I predict the following:

2. Increased membership in political, economic, and interventionist IOs will increase executive power relative to other domestic institutions.

Although strong executives are not inherently incompatible with democracy, they are problematic when institutional checks are underdeveloped, as is often the case in new democracies (Lijphart, 1977; O’Donnell, 1994). In the next section, I discuss how the limits that IOs place on states' domestic policy options inadvertently stunt the development of institutional checks on executive power.

\subsubsection{Direct Mechanism 2: Limiting the Domestic Policy Space}

The domestic policy space refers to the universe of policy alternatives political actors can feasibly debate, adopt varying positions on, and implement. A meaningful domestic policy space is critical for institutional development, conditions the extent to which leaders can govern effectively, and influences the strategies politicians adopt to appeal to voters during elections. In states with large policy spaces, institutions that aggregate mass interests and check executive power develop more fully, governments 
are better able to provide public goods, and, as a result, elections are contested along ideological lines. However, when the policy space is limited, institutions remain underdeveloped, and elections occur in a relative ideological void.

Scholars have studied how international economic interdependence impacts state policies, finding increased globalization, influence from international financial markets, and transnational capital induce economic policy convergence both across countries (Andrews, 1994; Cerny, 1994; Pierson, 1995; Mosley, 2000; Rodrik, 1997; Ross, 2000; Simmons and Elkins, 2004) and across parties within a country (Mishra, 1999). International financial pressures, which favor lower taxes, less economic regulation, and smaller governments, limit states' abilities to determine domestic economic policy (Haggard and Maxfield, 1996).

Mosley finds international financial markets have a strong but narrow impact on government policy in mature democracies: macro-economic policies, such as inflation rates, government deficit, and foreign exchange rates, are particularly susceptible to international pressures (Mosley, 2000). Penalties for policy divergence, such as higher interest rates, drive this cross-national convergence of macro-economic policies. The effect is likely even greater in developing countries, where international financial sanctions are more damaging and default risk is higher.

This research has been extended to consider the role of IOs specifically. Often, IOs specify policies states must implement in order to become or continue to be members. These conditions can include policy changes and economic or monetary reforms (Pevehouse, 2005); the upper limit the EU imposes on members' budget deficits is a salient example (Mosley, 2000). In addition to inducing cross-national economic policy convergence (Cao, 2009), IO membership has also been linked to national science (Finnemore, 1993), mass education (Meyer et al., 1992), and environmental policies 
(Frank, 1997). In short, IOs are found to have substantial and often converging effects on countries' domestic policy spaces.

A meaningful domestic policy space has implications for a variety of important outcomes in democracies. For example, an extensive policy space makes it easier for policy makers to adapt political decisions to align with and respond to changes in public opinion. The extent to which the policy space provides government discretion over areas such as industrial or agricultural policy also has critical implications for economic development, especially in newer, developing democracies. Finally, the nature of the domestic policy space has implications for democratic institutional development, again particularly in new democracies. Because this project focuses in particular on the institutional pre-requisites for democratic success - and, conversely, the institutions targeted by elected officials in cases of democratic backsliding - I focus here specifically on the implications that a limited domestic policy space has for institutional development, acknowledging that this is only one area where the policy space is relevant.

A meaningful domestic policy space plays an important role in developing representative institutions and institutional checks on executive power. First, an expansive domestic policy space creates opportunities for parties to develop. In developed systems, parties compete in elections by situating themselves along salient, politicized cleavages that give voters options based on policy-relevant issues (Lipset and Rokkan, 1967). However, IO requirements limit policy alternatives for political parties to adopt and debate since advocating policies that conflict with IO requirements is not electorally viable. The inability to debate substantive policy and ideological alternatives stunts party system development in new democracies because these parties are unable to develop coherent and distinct policy platforms to appeal to voters. This impedes 
long-term democratic quality and even consolidation, which depend in part on the extent to which parties structure political conflict (Dix, 1992; Mainwaring, 1998).

Indeed, scholars have shown economic globalization in general, as well as increased EU integration, have limited the range of feasible economic policy appeals governments and parties can make. Since voters are aware the governments' economic options are constrained (Hellwig, 2014), it is difficult for parties to differentiate themselves from one another based on economic appeals. Instead, they turn to populism or campaign on valence issues, or uncontroversial issues "on which all parties declare the same objective but dispute each other's competence in achieving the desired policy" (Kitschelt et al., 1999, 137), such as corruption, nationalism, or rule of law. This is true for all types of parties, not just new or niche ones (Ward et al., 2015).

The effects of the International Monetary Fund (IMF) on party development in Latin America illustrate these issues. In response to the global economic recession in the 1970s and 1980s, many Latin American governments borrowed heavily from international financial actors; this induced the Latin American debt crisis, which lasted for nearly a decade. Unable to repay their debts, governments turned to the IMF for loans. The IMF placed heavy conditions on these loans, requiring states to cut regulatory, redistributive, and social welfare policies. These neoliberal reforms included labor market liberalization, which resulted in less employment security as well as anti-inflationary and other austerity programs that decreased public spending. Ironically, historically labor-based parties often implemented these IMF-driven reforms. As a result, voters became increasingly detached from political parties, creating opportunities for individual politicians to appeal directly to voters without parties as intermediaries. In other words, IMF conditionality severely weakened political parties in new democracies in Latin America; in this particular context, weak parties created a space for populism to emerge as a political alternative (Pastor, 1987; Roberts, 2007). 
Intense austerity policies imposed by the $\mathrm{EU}$ and the IMF in Greece more recently have had similar effects (Vasilopoulou et al., 2014).

External policy requirements also infringe on one of the primary roles of legislatures: proposing, drafting, and implementing legislation. This stunts the institutionalization of the legislature in new democracies and contributes to power asymmetries between the executive and the legislature, which further hinders democratic progress in two ways. First, strong legislatures create an impetus for party system development. In states where legislatures are weak, parties lack a forum in which to develop and mature. Another consequence is that legislatures, which play a critical role in providing horizontal accountability, are unable to check executive power. Indeed, in addition to the judiciary, legislatures are the main institutional check on the executive (Fish, 2006).

Finally, the domestic policy space is linked to state fiscal capacity, and in particular a state's ability to govern effectively and provide public goods. State capacity, which consists of the extent to which the state is able to "maintain the rule of law, to protect the rights of citizens, and to regulate economic transactions" (Fortin, 2012, 904), is another important condition for long-term democratic success (Bäck and Hadenius, 2008). However, IOs restrict the economic and fiscal policy options available to states by limiting tariffs, public spending, and government deficits. These fiscal limits, in addition to restricting government control over economic policies, decrease government resources and revenue.

A state's fiscal space, or its ability to collect revenue to allocate toward public goods provision, impacts politicians' electoral strategies. When states have a large fiscal space, politicians campaign based on past evidence of effective public goods provision. However, external policy requirements limit the range of policies governments can credibly advocate and diminish the state's ability to collect revenue to 
provide public goods. When politicians are unable to use ideological positions and evidence of past economic success to appeal to voters, they turn instead to populism or clientelism; this style of politics impedes democratic progress in young democracies (Flores and Nooruddin, 2016).

To summarize, certain IOs impose policy requirements on their member states. The more IOs with policy requirements a state is a member of, the more policy constraints it faces. These policy requirements diminish states' domestic policy space, which stunts institutional development and limits governments' capacity to provide public goods; one consequence is that elections are contested in an ideological void. These effects are particularly pernicious in new democracies, where institutions are often underdeveloped and have been neglected by democracy-promoting IOs that instead favor elections and elites, and also in states where executives are already relatively strong due to IO membership. The combination of strong executives surrounded by weak institutions makes democratic backsliding more likely. As such, I predict the following:

3. Increased membership in international organizations with policy requirements will decrease a state's domestic policy space and stunt institutional development.

\subsection{Scope Conditions}

To further clarify the theoretical expectations outlined above, this section discusses the scope conditions of the theory, focusing in particular on the relevant set of IOs and states, and includes a brief discussion about the possible impact that region and time may have on expected outcomes.

As discussed above, this theory does not predict that membership in just any IO will be associated with democratic backsliding. Rather, this theory is relevant to a certain subset of IOs that actively engage in democracy promotion, have mechanisms 
for increasing relative executive power in their member states, and are structured such that they limit the domestic policy options available to their members. This includes IOs that explicitly reference support for democracy, human rights, or rule of law in one of their official organizational documents (von Borzyskowski and Vabulas, 2018); political and economic IOs, as these are found to be particularly effective at promoting democracy and democratic consolidation among new democracies (Poast and Urpelainen, 2018); and interventionist IOs, which are likely to both create forums for executives to exercise unmonitored international-level decision-making power and also have the tools to implement and enforce policy requirements in their member states.

It is important to note that most democratically committed IOs - and in particular those that intervene in domestic politics - are concentrated in Latin America and Europe. However, there are still prominent examples of these organizations in Africa and Asia as well, such as the African Union and Association of Southeast Asian Nations (ASEAN). However, even if most of these IOs are working in Europe and Latin America, the theory still has important implications. These are the regions where democracy is most common and also where it is most likely to succeed. Furthermore, these are the IOs that should be best equipped to promote democracy in their member states. Therefore, if they are trying yet failing to engage in democracy support and promotion, this is still an important finding in and of itself. Indeed, organizations such as the EU serve as models for countries in other regions working toward greater regional integration. Since this is the case, the extent to which the EU and other prominent democracy promoting organizations are effective has implications for IOs developing in other regions of the world.

As discussed further in Chapter 4, since there is reason to expect that regional trends are at play, I include varying intercepts for region in the models testing my 
theory and find evidence that there is in fact meaningful variation across regions. Yet, even controlling for these region-specific factors, I still find evidence of a significant relationship linking IO membership and democratic backsliding in new democracies.

Just as not all IOs are relevant to my theory, neither are all states. The relevant universe of target states for democracy promotion and support by IOs is, broadly speaking, developing democracies. I exclude mature democracies since these states democratized prior to the initiation of intense international democracy promotion and are often the countries that created the democracy promoting IOs in the first place. Although some have more recently suggested that mature democracies, including the United States, are also backsliding (or at least are showing symptoms of backsliding) (Ziblatt and Levitsky, 2018), I argue that these countries are not relevant for my theory. Although the proximate sources of backsliding in these cases may be similar to the mechanisms proposed by my theory - increased executive power and a limited domestic policy space due to global pressures - the process of institution building in these countries was categorically different. Unlike new democracies, these mature democracies developed their democratic institutions largely from the ground-up, without much if any influence from external actors.

With this in mind, I follow Flores and Nooruddin, who define developing democracies as states "for whom a democratic system was not a certainty in 1946 or in the year of its birth as a sovereign country, whichever came second" (Flores and Nooruddin, 2016, 85). By this definition, 19 countries are outside the scope of this theory: Australia, Austria, Belgium, Canada, Denmark, Finland, France, Germany, Iceland, Ireland, Japan, Luxembourg, the Netherlands, New Zealand, Norway, Sweden, Switzerland, the United Kingdom, and the United States. Of the remaining countries, I focus on democracies, defined as country-years with a Polity score greater than 5 (Marshall et al., 2016). As discussed in Chapter 4, I exclude anocracies 
and autocracies since backsliding is an intra-regime process which is both unique to democracies and results in illiberal or diminished democracy, not autocracy.

Finally, this theory's applicability is temporally, as well as geographically, bounded. International democracy promotion did not exist at all until the end of World War 2. To the extent that it was used throughout the Cold War period, however, its scope was much more limited than it is today, and its objectives were strongly linked to Cold War balancing considerations rather than to an actual desire to spread democracy. As discussed above, it was not until the end of the Cold War in 1989 that international democracy promotion expanded significantly and was focused more on democracy for the sake of democracy. Although democracy promotion was limited prior to 1989, I include observations from 1946 to the present in my analysis in the following chapter. I include the Cold War period since this is when the third wave of democracy began (specifically, in 1974 in Portugal). Therefore, it is important to capture these transitions to democracy since international support for democracy was one of the main distinguishing features of the third wave. Nevertheless, this theory is likely most relevant in the post Cold War period; I account for this in several ways when testing my theory.

For example, I estimate models with fixed effects by year, models that explicitly include year as a control variable, and of course I have models that include an indicator for whether or not an observation occurs prior to or after the end of the Cold War. All of these variations of the models find similar results to the main models (namely, a negative and significant relationship between increased IO membership and a state's subsequent democratic trajectory). To dig into it even more deeply, I also subset the data to 1990-2015 and 1945-1989 and estimate the models on each of these datasets separately. As discussed in Chapter 4, the results of these models suggest that the 
relationship between IOs and democratic backsliding in new democracies is indeed predominantly a post-Cold War phenomenon.

\subsection{Alternative Explanations}

Any observed relationship between membership in democracy promoting IOs and democratic backsliding in new democracies could be due to a series of alternative explanations other than that proposed by this project's theory. In this section, I outline and discuss these possible alternative explanations.

First, it may be that globalization and increased economic integration in general, rather than IO membership specifically, are linked to backsliding. This is entirely plausible, especially considering the fact that the surge in IO creation (and IO membership) closely coincided with increased globalization following the end of the Cold War. Furthermore, in the same ways that I argue IOs limit the domestic policy space in their member states, globalization and economic integration, which can involve deals such as free trade agreements, can also constrain policy options available to domestic leaders. However, there are additional factors contributing to backsliding that I contend are unique to IOs specifically. In particular, increased globalization should not necessarily be linked to democracy promotion that focuses specifically on elections and elites at the expense of building up other domestic institutions; this is specifically an impact of democracy promoting agents, such as IOs. Furthermore, while increased interactions between states may indirectly increase executives' decision-making power, these effects are particularly likely to manifest in international fora, such as in the context of IOs. Nevertheless, since there is significant overlaps between globalization and IOs, I estimate models in Chapter 4 that take into account these other relevant international processes. Even controlling for the post-Cold War period, foreign direct investment, and trade openness - three commonly used proxies 
for globalization - I find that IOs still have an independent and significant impact on democratic trajectories in new democracies.

Second, a related concern may be that recent backsliding around the world is primarily due to the 2008 global financial crisis. Although the financial crisis is undoubtedly a contributing factor, as least in some cases, I contend it does not fully explain previous and ongoing trends. For example, in 2010 when the Fidesz party came to power in Hungary under Prime Minister Orbán, Hungary was in the midst of a deep economic crisis. However, Poland, where backsliding trends have been similar to those in Hungary, was the only member of the EU that managed to avoid recession following the 2008 crisis and in 2015, when the Polish far-right Law and Justice Party (PiS) came to power, unemployment was quite low in Poland. Despite this, similar outcomes have emerged in Hungary and Poland. This suggests that economic crisis may be one, but not the only or full, explanation for recent backsliding.

However, to the extent that the economic crisis did contribute to backsliding in certain cases, I argue this explanation, rather than constituting an alternative explanation, is consistent with my theory. International responses to the financial crisis contributed to backsliding in certain states. For example, following the financial crisis in Greece, the EU, the IMF, and the World Bank imposed extensive austerity policies on Greece. These policy requirements have been linked to the more recent rise of populist far-right parties in Greece, such as Golden Dawn. Similar trends emerged in Latin America during the 1970s and 1980s following the Latin American financial crisis and subsequent IMF intervention. The IMF also placed heavy conditions on loans to Latin American countries, and it was often historically labor-oriented parties that had to implement these reforms. This created an opportunity for individual populist politicians to gain a foothold in politics and weakened the party systems in these countries. 
Third, culture may be a source of backsliding in these new democracies. Indeed, cultural explanations are prominent in theories of democracy (Almond and Verba, 1963; Inglehart and Welzel, 2005; Putnam, 1993) yet are largely absent from my theory above, which is heavily focused on institutional and political-economic explanations of backsliding. Is it simply that states that are backsliding do not (yet) have the type of culture that supports democracy, and in particular the liberal aspects of democracy? I argue that cultural explanations of backsliding are insufficient. Cultural theories of democratization are essentially structural ones: culture consists of a set of societal norms, often inherited from past generations, that only change gradually over time. However, structural theories in general are found to lack explanatory power with respect to the third wave of democracy (Haggard and Kaufman, 2016), to which this theory applies. Furthermore, a cultural explanation of backsliding would imply that societies had cultures amenable to democracy when they made their initial (and historically recent) transitions to democracy, yet over the course of several decades or less the culture shifted to be anti-democratic (Waldner and Lust, 2018). Given that culture is relatively sticky, this seems unlikely.

Nevertheless, in the models in Chapter 4, I attempt to take culture into account empirically. Although the main results I show are ordinary least squares (OLS) models with varying intercepts, I also estimate the same models with fixed effects for both country and region. The country fixed effects models allow me to control for time-invariant characteristics of states. Research shows that culture is a complex concept that is difficult to measure but also sticky and slow to change; therefore, these country fixed effects should be picking up on any unobservable aspects of culture in a country. Controlling for time-invariant, state-level characteristics, I still find that IO membership has an independent and significant relationship with backsliding in new democracies. 
Related to these cultural explanations, theorists have noted that there is an inherent tension between liberalism and democracy (Bobbio, 1988; Canovan, 1999; Graham, 1992; Zakaria, 1997). As Hayek (quoted in Graham (1992)) explains:

Liberalism requires that all power, and this must include the power of the majority, must be circumscribed. Democracy, by contrast, tends to the view that the opinion of the majority constitutes the sole limit to the powers of the government. The difference between the two principles is clearly apparent when we recall that the opposite of democracy is authoritarianism, and the opposite of liberty totalitarianism. (Graham, 1992, 149)

Given this tension, is the proposed theory in this project simply about new democracies that are backsliding with respect to liberal democracy? If so, is this surprising given that liberalism and democracy are incompatible to a certain extent? Are these states backsliding simply with respect to liberalism, but not democracy?

Admittedly some of the institutions included in my theory, and also in the corresponding DIS index I create to measure backsliding, are not exclusively democratic institutions; rather, they do focus on more liberal components of a state. However, this is because I am largely relying on how the existing literature defines modern democracy. The shift more recently has been toward broader definitions of democracy that go beyond minimalist characteristics, such as elections and mass participation in politics, with studies showing that independent judiciaries and strong legislatures are also important components of democratic success (Fish, 2006; Gibler and Randazzo, 2011; Graham et al., 2017). Today, every modern democracy involves some level of delegation to non-majoritarian institutions; therefore, it is difficult to exclude these other, liberal institutions from the definition of democracy.

Furthermore, even if the relationship between IOs and democratic backsliding is in fact reflecting erosions of liberal democracy, and not of democracy more broadly 
defined, this still has critical policy implications. In the current international environment, democracy is essentially equated with liberal democracy. As a result, when IOs and other international actors engage in democracy promotion, they are attempting to promote liberal democracy. Therefore, regardless of whether or not liberalism and democracy are incompatible, it is still critical to study and test the extent to which IOs are achieving their stated policy goals. My theory contends that although these organizations are promoting minimal forms of democracy, they are also inadvertently undermining other critical institutions associated with democracy; as a result, they are failing to promote liberal democracy and ongoing democratic progress and consolidation.

Finally, it is possible that any observed relationship between increased membership in democratically committed IOs and backsliding is a story of reverse causality. Is it that new democracies that are already struggling to maintain their new democratic institutions are joining IOs in an attempt to guard against backsliding, but then backsliding nonetheless? While this is possible, I argue that it is unlikely, for a few reasons. First, it is unlikely that states can anticipate future backsliding. To the extent that they can, executives would be the most likely to foresee these future erosions. This is because, as my definition of backsliding from Chapter 2 specifies, backsliding tends to be an executive-led process. However, executives also tend to be the main beneficiaries of backsliding in that it increases their relative power. What is more, executives are one of the primary decision-makers when it comes to whether or not a state joins an IO. Therefore, even if executives were to anticipate backsliding, there is no reason to expect that they would seek to join IOs in an attempt to guard against the process. 


\subsection{The Counterfactual and Research Design}

The proposed theory in this chapter does not argue against research finding that IOs, and international democratic norms and democracy promotion more broadly, provide important incentives and resources that help developing states democratize. Without these incentives from IOs, many states would arguably not have democratized at all, and thus the outcome would be autocracy or semi-authoritarianism rather than the diminished or illiberal form of democracy that results from backsliding. Therefore, the net impact of IOs on states' levels of democracy should still be positive: IOs make states overall more democratic when compared to autocracies. Indeed, using my DIS index as a measure of democracy, I am able to replicate existing findings that link IOs to higher levels of democracy when compared to autocracy (Pevehouse, 2005).

Instead, the argument here builds on this existing work on IOs and regime outcomes, taking it one step further. Although IOs are associated with overall higher levels of democracy, they are more limited in their ability to promote ongoing democratic progress among democracies and can even unintentionally create conditions conducive to backsliding. Using their current approaches to democracy promotion, these IOs are unable to promote anything beyond minimalist democracy, characterized primarily by free and fair elections and mass participation in politics, and they can even make backsliding more likely. This is because they focus predominantly on minimalist aspects of democracy, alter the domestic institutional balance of power, and constrain the domestic policy space.

Therefore, the relevant counterfactual for this theory would be a situation in which IOs continue to create incentives and provide support for states to transition to democracy, yet they approach membership requirements for new democracies differently, in 
several ways. First, in this counterfactual world, IOs would not impose extensive policy requirements and limit policy options on new democracies before they have developed important democratic institutions, in addition to elections, that can act as a check on executive power. Furthermore, these IOs might instead channel more resources toward actively building up these critical representative institutions and institutional checks on executive power, such as legislatures, political party systems, civil society, independent judiciaries, and the media, rather than focusing exclusively on elections and elites. This would require both more oversight on the part of IOs and also longer time horizons to allow domestic institutions to develop from the bottomup, with external aid.

To illustrate, consider the case of Hungary and the EU. The relevant counterfactual to Hungary today is not what type of regime Hungary would have had if it had never joined the EU. Rather, the counterfactual is what Hungary would look like today if the EU has focused more on developing institutional checks on executive power and had waited longer before requiring Hungary to adopt the extensive number of policies linked to the European common market. I argue that in this counterfactual scenario, Hungary would not have experienced executive-led democratic backsliding.

Unfortunately, it is very difficult to observe the counterfactual to this theory, for several reasons. First, all new democracies, or at least those that have been relatively successful democracies, are members of these IOs that engage in democracy support and promotion. What is more, these states began joining these IOs shortly after their democratic transitions. Therefore, there are no (successful) observable cases of democratization without heavy influence from IOs. Furthermore, due to the intense emphasis that the international community has placed on free and fair elections as a signal and initial phase of democratization, most democracy promoting IOs focus heavily on these minimalist forms of democracy promotion. As such, there 
are few empirical cases of alternative forms of democracy promotion to leverage as counterfactual treatments.

Ideally, I would be able to use natural experiments to test this theory. Unfortunately, these situations are particularly difficult to find in the case of IOs and states. Therefore, I rely on observational data to test the proposed theory. In the following chapters, I use these data to test the theory and approximate the counterfactual in several different ways.

To test the theory, I combine cross-national analysis with in-depth case studies. In Chapter 4, I use both original and existing data to test the overarching prediction of my theory: increased membership in relevant IOs is associated with subsequent backsliding in new democracies. I also use cross-national data to test the proposed direct mechanisms linking IOs and backsliding: increased executive power and a diminished domestic policy space. More specifically, as discussed in Section 3.3.2, to approximate the counterfactual, in Chapter 4 I look at different groups and types of democracy supporting and promoting IOs individually in an attempt to identify any variation across IO groups with respect to their impact on states' democratic trajectories, finding that IOs predicted to influence democratic outcomes in their member states are associated with democratic backsliding in new democracies. In addition, I conduct several placebo tests. Although the results are not consistent throughout, in the full models, I find that IOs not predicted to influence regime outcomes - specifically, non-democratic, non-political and non-economic, and minimalist (as opposed to interventionist) - have no significant relationship with states' probabilities of backsliding.

Although these cross-national tests of the theory suggest there is a meaningful relationship between increased membership in IOs relevant to democratic outcomes and backsliding, these findings are largely relational, rather than causal. Therefore, to 
more directly trace the proposed mechanisms linking IO membership to backsliding, Chapter 5 develops an in-depth case study of the EU. According to existing research, the $\mathrm{EU}$ is one of if not the best $\mathrm{IO}$ with respect to democracy promotion among its member states. As such, this should be a particularly hard case for my theory: if there is evidence linking the EU to backsliding, this would provide further support for my theory. Indeed, despite the EU's extensive democratic credentials, there has recently been evidence of backsliding in several of its newly democratic member states. Focusing on the two most extreme cases of backsliding to date in the EU-Hungary and Poland-I trace the ways in which the EU increased executive power and limited policy options as these two countries were initially developing their democratic institutions.

In addition to using these cases to trace the proposed mechanisms, I also use this case study of the EU to approximate the counterfactual for my theory, using a synthetic case control. Again, especially in Europe, all relatively successful new democracies are member of the EU; thus, there are no observable counterfactuals. Therefore, I use the synthetic control method, which uses pre-treatment characteristics of treated units (EU member states) to choose how to weight potential control units. These weighted control units are used to construct a synthetic case that is similar to the treated unit along all relevant dimensions other than treatment status (EU accession). Using this method, I find evidence that EU accession has had a negative and significant treatment effect on Hungary's democratic trajectory. 


\section{Chapter 4: Linking International Organizations to Democratic Backsliding: A Cross-National Analysis}

The previous chapter argues that, although democracy promoting international organizations (IOs) can promote initial transitions to democracy in developing states, as existing research finds, they are more limited in their abilities to promote ongoing democratic progress and consolidation in new democracies. I argue that these organizations unintentionally contribute to backsliding in new democracies in several ways. First, they do so indirectly by focusing on elites and elections at the expense of other important representative institutions and institutional checks on government power, such as political parties, legislatures, and independent judiciaries. They also more directly contribute to backsliding by simultaneously increasing executive power and limiting the domestic policy space, which stunts the development of those critical representative institutions in new democracies.

This chapter combines original and existing data on IOs with the Democratic Institutional Strength (DIS) index presented in Chapter 2 to test my theory linking IOs to democratic backsliding in new democracies at the cross-national level. I find that increased membership in three groups of IOs associated with democratic success - democratically committed, political or economic, and interventionist IOsmakes subsequent backsliding more likely in new democracies. I also test and find support for the proposed mechanisms: IO membership is linked to increased executive 
power, constraints on the domestic policy space, and ideological convergence across political parties.

The next section outlines the research design for and then tests the overarching theory linking IOs to backsliding in new democracies. After providing evidence in support of the theory and Hypothesis 1, the remainder of the chapter tests and finds support for the direct mechanisms linking IOs to backsliding, as discussed in Hypotheses 2 and 3.

\section{$4.1 \quad$ Research Design}

I use data on IO membership and regime outcomes to test Hypothesis 1 which predicts that membership in IOs makes subsequent democratic backsliding more likely in new democracies. I exclude mature democracies, which democratized prior to the recent surge in democracy promotion by IOs. Flores and Nooruddin define developing democracies as states "for whom a democratic system was not a certainty in 1946 or in the year of its birth as a sovereign country, whichever came second" (Flores and Nooruddin, 2016, 85). By this definition, 19 countries are excluded from the analysis: Australia, Austria, Belgium, Canada, Denmark, Finland, France, Germany, Iceland, Ireland, Japan, Luxembourg, the Netherlands, New Zealand, Norway, Sweden, Switzerland, the United Kingdom, and the United States. Of the remaining countries, I focus on democracies defined as country-years with a Polity score greater than 5 (Marshall et al., 2016). I exclude anocracies and autocracies since

backsliding is an intra-regime process resulting in illiberal or diminished democracy, not autocracy. 


\subsubsection{Dependent Variable: The DIS Index}

I use my original indicator of backsliding, the DIS index, to construct the dependent variable. I depart from existing work that focuses on the relationship between IOs and levels of democracy and consider instead changes in levels of democracy. This choice is driven by my theory and by my definition of backsliding: I predict IOs make subsequent backsliding, which is conceptually a decrease in a state's level of democracy, more likely. I do not argue IOs are negatively associated with overall levels of democracy: more democratic states are undoubtedly more likely to be in the types of IOs I consider. Rather, I argue these IOs make new democracies more susceptible to democratic erosion.

Backsliding is an incremental process that occurs over time (Waldner and Lust, 2018); as such, 1-year changes are unlikely to capture this phenomenon. Therefore, the dependent variable is the 5-year change in a state's DIS index. A negative value on the dependent variable indicates a state has experienced backsliding between times $t-5$ and $t$, positive values indicate democratic progress, and 0 indicates no change. A total of $36.3 \%$ of country-year observations in the data are cases of backsliding, or instances where the 5-year change in the DIS index was negative.

\subsubsection{Independent Variables: IO Membership}

The main independent variables are counts of state memberships in certain types of IOs. I focus on three types of IOs that are most likely to influence domestic democratic institutions, executive power, and policy outcomes: IOs explicitly committed to promoting and supporting democracy; political or economic IOs; and the most institutionalized types of IOs, interventionist ones. I construct my main independent variables by building on these categories. 
Democratically committed IOs are "those organizations that reference democracy, human rights, or the rule of law in their constitutive documents" (von Borzyskowski and Vabulas, 2018, 5). This is distinct from Pevehouse's democratic IOs, which are organizations composed primarily if not exclusively of democratic states (Pevehouse, 2005). In total, there are 56 IOs that meet these criteria. A list of these IOs, as well as the years when they first expressed a commitment to democracy, can be found in Table 4.1.

In addition, I consider the possibility that democratically committed IOs with total or near universal membership, such as the United Nations, are less likely to actively require member states to maintain democratic standards. Therefore, I create a second group that includes only non-universal democratically committed IOs. Of the 56 IOs from Appendix 4.1, I exclude the following: the International Commission on Civil Status, the International Criminal Court, the International Criminal Police Commission, the International Labor Organization, UNESCO, the United Nations, and the World Tourism Organization.

Next, I focus on political and economic IOs. Poast and Urpelainen (2015), building on Mansfield and Pevehouse (2008) and Ingram et al. (2005), create a new classification of the function of the 494 organizations found in version 2.0 of the Correlations of War dataset (Pevehouse et al., 2004), which has data on IO membership for the years 1816-2000. Poast and Urpelainen's classification expands Ingram et al.'s categorization of IO functionality from four groups - general, political, economic, and social - to six mutually exclusive groups - political, general-economic, commodityeconomic, resource-economic, technical, and unclassified - and covers the years 1946 to 2000. Using version 3.0 of the Correlates of War dataset on IO membership (Pevehouse et al., 2016), which extends the data to 2014 and includes state membership for 534 IOs, I use Poast and Urpelainen's classification and coding strategy to code the 
Table 4.1: Democratically Committed IOs Reference Support for Democracy, Human Rights, and/or Rule of Law in Their Constitutive Documents (von Borzyskowski and Vabulas, 2018).

\begin{tabular}{|c|c|}
\hline IO Name & Year of Commitment \\
\hline ACP Group & 1992 \\
\hline ACP/EU Joint Assembly & 2000 \\
\hline African Union & 2000 \\
\hline Andean Pact & 1989 \\
\hline Andean Parliament & 1979 \\
\hline Arab Maghreb Union & 1989 \\
\hline Association of Caribbean States & 1994 \\
\hline Association of Southeast Asian Nations & 2007 \\
\hline Benelux Community & 1958 \\
\hline Black Sea Economic Council & 1992 \\
\hline Caribbean Community & 2001 \\
\hline Central African Economic \& Monetary Union & 1994 \\
\hline Central American Integration System & 1991 \\
\hline Central European FTA & 1992 \\
\hline Central European Initiative & 1989 \\
\hline Comm Market for East/South Africa & 1993 \\
\hline Comm Portuguese Speaking Countries & 1996 \\
\hline Commonwealth of Independent States & 1994 \\
\hline Commonwealth Secretariat & 1971 \\
\hline Conf. on Interaction \& Confidence-Building Measures in Asia & 2002 \\
\hline Council of Europe & 1949 \\
\hline Economic Community of Central African States & 1983 \\
\hline Economic Community of Great Lakes States & 2006 \\
\hline Economic Community of West African States & 1995 \\
\hline European Bank for Reconstruction \& Development & 1991 \\
\hline European Coal \& Steel Community & 1951 \\
\hline European Union & 1988 \\
\hline Francophone Agency & 2005 \\
\hline Fund 4 Devel. of Indigen Peoples of LA/Carib & 1992 \\
\hline Global Environ. Fund & 1991 \\
\hline Ibero-American General Secretariat & 2003 \\
\hline Inter-American Defense Board & 1942 \\
\hline Instit Nutrition for Cent Am \& Pan & 1949 \\
\hline International Criminal Court & 1998 \\
\hline Intl Criminal Police Comm & 1956 \\
\hline Intl Comm on Civil Status & 1952 \\
\hline Intl Labour Org & 1919 \\
\hline MERCOSUR & 1998 \\
\hline North Atlantic Treaty Org & 1949 \\
\hline Observatorie economique statistique sub-Saharan Afr. & 1993 \\
\hline Org. Eastern Caribbean States & 1981 \\
\hline Org. Islamic Conference & 1974 \\
\hline Org. Security Cooperation Europe & 1990 \\
\hline Pacific Island Forum & 2000 \\
\hline Pan-African Parliament & 2000 \\
\hline Pan-Am Union/Org of Am States & 1948 \\
\hline Regional Centre on Small Arms and Light Weapons & 2000 \\
\hline Rio Group & 1999 \\
\hline Sec. for the Commission for East Afr. Coop. & 2001 \\
\hline Southeast Asian Minist. of Educ. Org. & 1968 \\
\hline Southern African CU & 2002 \\
\hline Southern African Dev. Community & 1992 \\
\hline UN Education, Scientific, \& Cultural Org & 1945 \\
\hline United Nations & 1945 \\
\hline Western European Union & 1948 \\
\hline World Tourism Org. & 1970 \\
\hline
\end{tabular}


functionality of democratically committed IOs that were created after the year 2000 (Ingram et al., 2005; Mansfield and Pevehouse, 2008; Poast and Urpelainen, 2015).

Finally, it is likely that only certain types of IOs have the capacity to influence state behavior. Therefore, I further distinguish between interventionist IOs and other less institutionalized organizations. I expect interventionist IOs to be particularly likely to influence domestic outcomes. To identify these IOs, I use Boehmer et al.'s three-level coding scheme (Boehmer et al., 2004). ${ }^{7}$

These groups of IOs are not mutually exclusive. Some democratically committed IOs, such as the European Bank for Reconstruction and Development (EBRD), are interventionist, while others, such as the Francophone Agency, are minimalist. Similarly, certain political or economic organizations, such as the International Labor Organization, are explicitly committed to democracy, whereas others, such as the International Monetary Fund (IMF), are not. Table 4.2 summarizes the types of IOs used to test Hypothesis 1, giving examples of organizations that fall within these categories.

IO membership entails a number of ongoing policy commitments that states must meet and opportunities for executives to alter the distribution of domestic power in their favor; these commitments and opportunities continue beyond the accession date. Since this is the case, the main independent variables are counts of a state's number of memberships in different types of IOs. Specifically, using the data described above and IO membership data from the Correlates of War dataset (Pevehouse et al., 2016), I

\footnotetext{
${ }^{7}$ I use the most recent version of the IO institutionalization data, which updated the coding from their 2004 article (Gartzke et al., 2012). The sample of IOs coded by Boehmer et al. is only a subset of all IOs but includes IOs at all levels of institutionalization. It is important to note that I found several discrepancies in the data, which were confirmed by Charles Boehmer. Specifically, the dataset widely used in the literature miscodes the following IOs: the United Nations, the Central European Initiative, the European Union, and the League of Arab States. I manually corrected these IOs, but the possibility of other coding errors remains.
} 
Table 4.2: International Organizations Relevant to Democratic Outcomes

\begin{tabular}{|l|c|c|c|c|c|}
\hline & Democratic & Elections & $\begin{array}{c}\text { Technical } \\
\text { Aid }\end{array}$ & $\begin{array}{c}\text { Political } \\
\text { or } \\
\text { Economic }\end{array}$ & $\begin{array}{c}\text { Interven- } \\
\text { tionist }\end{array}$ \\
\hline \hline African Union & $\checkmark$ & $\checkmark$ & $\checkmark$ & $\checkmark$ & \\
\hline Council of Europe & $\checkmark$ & $\checkmark$ & $\checkmark$ & $\checkmark$ & \\
\hline ECOWAS & $\checkmark$ & $\checkmark$ & $\checkmark$ & $\checkmark$ & \\
\hline OAS & $\checkmark$ & $\checkmark$ & $\checkmark$ & $\checkmark$ & \\
\hline IMF & & & & $\checkmark$ & $\checkmark$ \\
\hline World Bank & & & & $\checkmark$ & $\checkmark$ \\
\hline ERBD & $\checkmark$ & & & $\checkmark$ & $\checkmark$ \\
\hline Mercosur & $\checkmark$ & & & $\checkmark$ & \\
\hline EU & $\checkmark$ & $\checkmark$ & $\checkmark$ & $\checkmark$ & $\checkmark$ \\
\hline
\end{tabular}

create a series of variables measuring the number of universal democratically committed, non-universal democratically committed, political or economic, ${ }^{8}$ democratically committed political or economic, and interventionist IOs a state is a member of in a given year.

Since the dependent variable is the 5-year change in a state's level of democracy, I lag these counts by 5 years. Therefore, an observation consists of an independent variable counting the number of certain types of IOs a state was a member of 5 years prior and the subsequent 5-year change in its democracy level.

\footnotetext{
${ }^{8}$ Specifically, the independent variables counting memberships in political or economic IOs include the following categories: political cooperation (general), human rights, security, international law, economic cooperation (general), investment, regulation, development banks, reparations, monetary unions, autonomous central banks, development funds/agencies, monetary funds (currency stabilization), reinsurance corporations, and central bank associations.
} 


\subsubsection{Control Variables}

Drawing on the existing theoretical expectations about democratic backsliding discussed in Chapters 2 and 3, I control for a number of state and regional characteristics relevant to democratic outcomes. First, scholars have posited that economic recession may be a source of backsliding (Sánchez-Cuenca, 2017; Svolik, 2008), and an entire field of research finds that development and democracy are highly correlated (Lipset, 1959); therefore, I control for GDP per capita (logged) and GDP growth per capita (Feenstra et al., 2015). Since strong parties are important characteristics of successful democracies (Mainwaring, 1998), I also include a measure of the effective number of political parties (Cruz et al., 2016), predicting higher levels will be associated with democratic progress (Mainwaring and Scully, 1995). To account for diffusion effects at the regional level, I control for the average change in the DIS scores of a region over the relevant time period (Gleditsch and Ward, 2006; Simmons et al., 2006). For this variable, I group countries by the 22 United Nations regions.

Because research on democratic backsliding is still developing, I also rely on theories of democracy more broadly to identify additional relevant controls. I include an indicator for whether or not a state was involved in an internal conflict, as conflict is found to negatively impact democracy (Hegre, 2014). ${ }^{9}$ Although the relationship between oil and democracy is debated (Brooks and Kurtz, 2016; Ross, 2015), research suggests the two are related; therefore, I control for a country's annual oil income per capita, calculated using Ross and Mahdavi's data on gas and oil production and

\footnotetext{
${ }^{9}$ I define a conflict-year as any year where a state was involved in either a purely internal conflict or an internationalized internal conflict, which is any armed conflict with a minimum of 25 battlerelated deaths (Gleditsch et al., 2002; Allansson et al., 2017).
} 
prices (Ross and Mahdavi, 2015). I also control for ethnic fractionalization, which is often linked to regime outcomes (Alesina et al., 2003). ${ }^{10}$

Since the dependent variable is the change in a state's level of democracy, I include a measure of a state's level of democracy at the beginning of the observation (at time $t-5)$. In addition, any observed relationship between IOs and subsequent backsliding might simply result from states artificially increasing their levels of democracy prior to joining an IO and then regressing to the mean following accession. Alternatively, states that are struggling with democracy may join additional IOs to safeguard democracy but then continue backsliding. To control for these possibilities, I include the 5-year lag of the dependent variable (the 5-year change in a state's level of democracy immediately prior to a given observation).

Each independent variable is lagged by 5 years to guard against endogeneity, and all observations are at the country-year level and include data on new democracies from 1946 to 2015. Summary statistics can be found in Table 4.3. Finally, all variables, including the dependent variable, are standardized to facilitate interpretation.

\subsection{Results}

I estimate a series of ordinary least squares (OLS) models with varying intercepts by country and region. ${ }^{11}$ These models allow me to capture unmeasured factors at the country and regional level that might influence a state's propensity to backslide. Furthermore, in grouping countries by political-geographic regions, these models leverage information from other states within a country's neighborhood, many of which are

\footnotetext{
${ }^{10}$ To measure fractionalization, I use data on ethnic groups (Nardulli et al., 2012), and I calculate ethnic fractionalization as $F \equiv 1-\sum_{i=1}^{n} p_{i}^{2}$, where $p_{1}, p_{2}, p_{3}, \ldots p_{n}$ is the population share of each ethnic group in a country (Fearon, 2003).

${ }^{11}$ As with the measure of the change in regional DIS scores discussed above, I group countries by the UN's 22 geographic regions. Models that include only varying intercepts by country and then only region yield similar results. See Appendix A.1.
} 
Table 4.3: Summary Statistics. IOs and Democratic Backsliding

\begin{tabular}{lrrrcc}
\hline \hline Statistic & $\mathrm{N}$ & Mean & St. Dev. & Min & Max \\
\hline DIS index (5-year change) & 2,389 & 0.19 & 0.46 & -0.76 & 3.76 \\
Num. demo. IO memberships & 2,513 & 9.10 & 4.06 & 0 & 18 \\
Num. political/economic IO mems. & 2,513 & 21.44 & 8.33 & 0 & 39 \\
Num. interven IO mems. & 2,513 & 14.46 & 4.77 & 0 & 24 \\
Num. elec. monitor IO mems. & 2,513 & 3.20 & 1.86 & 0 & 7 \\
Num. tech assist IO mems. & 2,513 & 4.20 & 1.85 & 0 & 8 \\
GDP pc (logged) & 2,276 & 8.81 & 0.99 & 6.22 & 10.74 \\
GDP growth pc & 2,250 & 2.82 & 5.95 & -41.63 & 33.76 \\
DIS index & 2,513 & 0.92 & 0.51 & -0.52 & 2.66 \\
Mean region DIS change & 2,080 & 0.08 & 0.17 & -0.41 & 1.55 \\
Effective number of parties (logged) & 1,645 & 6.08 & 0.76 & 1.61 & 6.55 \\
State age (logged) & 2,513 & 3.80 & 1.22 & 0.00 & 5.29 \\
Internal conflict & 2,513 & 0.14 & 0.34 & 0 & 1 \\
Oil income pc & 2,339 & 150.82 & 590.23 & 0.00 & $7,881.68$ \\
Ethnic frac. & 2,219 & 0.49 & 0.30 & 0.0001 & 1.00 \\
\hline
\end{tabular}

likely in the same IOs due to the often regional nature of these organizations (Shanks et al., 1996). Leveraging this regional-level information is important because my dataset is relatively small: the maximum number of observations per state is 69 . The standard alternative modeling approach, fixed effects models, produces coefficient estimates with high error levels when there is a small number of observations per unit (Clark and Linzer, 2015; Gelman and Hill, 2007). ${ }^{12}$

\footnotetext{
${ }^{12}$ Nevertheless, I re-estimate the same models using OLS with country and year fixed effects and find similar results. See Appendix A.2.
} 
Table 4.4: Number of IO Memberships and Democratic Backsliding. Varying Intercepts by Country and Region

\begin{tabular}{|c|c|c|c|c|c|}
\hline & Demo IO & Non-Univ Demo IO & Pol/Econ IO & Demo Pol/Econ IO & Interven IO \\
\hline Num. IO memberships 5 years prior & $\begin{array}{c}-0.16^{* *} \\
(0.03)\end{array}$ & $\begin{array}{c}-0.12^{* *} \\
(0.02)\end{array}$ & $\begin{array}{c}-0.18^{* *} \\
(0.04)\end{array}$ & $\begin{array}{c}-0.11^{* *} \\
(0.02)\end{array}$ & $\begin{array}{c}-0.24^{* *} \\
(0.05)\end{array}$ \\
\hline GDP pc (log) & $\begin{array}{l}0.57^{* *} \\
(0.05)\end{array}$ & $\begin{array}{l}0.55^{* *} \\
(0.05)\end{array}$ & $\begin{array}{l}0.52^{* *} \\
(0.05)\end{array}$ & $\begin{array}{l}0.53^{* *} \\
(0.05)\end{array}$ & $\begin{array}{l}0.49^{* *} \\
(0.05)\end{array}$ \\
\hline GDP growth pc & $\begin{array}{c}-0.04^{* *} \\
(0.01)\end{array}$ & $\begin{array}{c}-0.04^{* *} \\
(0.01)\end{array}$ & $\begin{array}{c}-0.04^{* *} \\
(0.01)\end{array}$ & $\begin{array}{c}-0.04^{* *} \\
(0.01)\end{array}$ & $\begin{array}{c}-0.04^{* *} \\
(0.01)\end{array}$ \\
\hline DIS index & $\begin{array}{c}-1.94^{* *} \\
(0.03)\end{array}$ & $\begin{array}{c}-1.94^{* *} \\
(0.03)\end{array}$ & $\begin{array}{c}-1.94^{* *} \\
(0.03)\end{array}$ & $\begin{array}{c}-1.95^{* *} \\
(0.03)\end{array}$ & $\begin{array}{c}-1.94^{* *} \\
(0.03)\end{array}$ \\
\hline Effec. num. parties (log) & $\begin{array}{c}0.01 \\
(0.02)\end{array}$ & $\begin{array}{c}0.01 \\
(0.02)\end{array}$ & $\begin{array}{c}0.01 \\
(0.02)\end{array}$ & $\begin{array}{c}0.01 \\
(0.02)\end{array}$ & $\begin{array}{c}0.01 \\
(0.02)\end{array}$ \\
\hline State age $(\log )$ & $\begin{array}{c}0.00 \\
(0.03)\end{array}$ & $\begin{array}{l}-0.01 \\
(0.03)\end{array}$ & $\begin{array}{l}-0.01 \\
(0.03)\end{array}$ & $\begin{array}{l}-0.00 \\
(0.03)\end{array}$ & $\begin{array}{l}-0.01 \\
(0.03)\end{array}$ \\
\hline Internal conflict & $\begin{array}{l}-0.00 \\
(0.01)\end{array}$ & $\begin{array}{l}-0.00 \\
(0.01)\end{array}$ & $\begin{array}{c}0.00 \\
(0.01)\end{array}$ & $\begin{array}{l}-0.00 \\
(0.01)\end{array}$ & $\begin{array}{c}0.01 \\
(0.01)\end{array}$ \\
\hline Oil income pc & $\begin{array}{l}0.94^{* *} \\
(0.16)\end{array}$ & $\begin{array}{l}0.93^{* *} \\
(0.16)\end{array}$ & $\begin{array}{l}0.84^{* *} \\
(0.17)\end{array}$ & $\begin{array}{l}0.95^{* *} \\
(0.16)\end{array}$ & $\begin{array}{l}0.82^{* *} \\
(0.17)\end{array}$ \\
\hline Ethnic frac. & $\begin{array}{c}-0.28^{* *} \\
(0.11)\end{array}$ & $\begin{array}{c}-0.28^{* *} \\
(0.11)\end{array}$ & $\begin{array}{c}-0.31^{* *} \\
(0.11)\end{array}$ & $\begin{array}{c}-0.29^{* *} \\
(0.11)\end{array}$ & $\begin{array}{c}-0.33^{* *} \\
(0.11)\end{array}$ \\
\hline Mean region DIS change & $\begin{array}{l}-0.02 \\
(0.01)\end{array}$ & $\begin{array}{l}-0.02 \\
(0.01)\end{array}$ & $\begin{array}{l}-0.00 \\
(0.01)\end{array}$ & $\begin{array}{l}-0.01 \\
(0.01)\end{array}$ & $\begin{array}{c}0.00 \\
(0.01)\end{array}$ \\
\hline Lagged DV & $\begin{array}{c}-0.04^{* *} \\
(0.01)\end{array}$ & $\begin{array}{c}-0.04^{* *} \\
(0.01)\end{array}$ & $\begin{array}{c}-0.04^{* *} \\
(0.01)\end{array}$ & $\begin{array}{c}-0.03^{* *} \\
(0.01)\end{array}$ & $\begin{array}{c}-0.04^{* *} \\
(0.01)\end{array}$ \\
\hline AIC & 1105.28 & 1106.69 & 1120.70 & 1114.84 & 1118.26 \\
\hline $\mathrm{BIC}$ & 1182.86 & 1184.26 & 1198.27 & 1192.42 & 1195.84 \\
\hline Log. lik. & -537.64 & -538.34 & -545.35 & -542.42 & -544.13 \\
\hline Observations & 1302 & 1302 & 1302 & 1302 & 1302 \\
\hline Num. countries & 70 & 70 & 70 & 70 & 70 \\
\hline Num. regions & 15 & 15 & 15 & 15 & 15 \\
\hline Variance: countries & 0.70 & 0.70 & 0.72 & 0.72 & 0.78 \\
\hline Variance: regions & 0.25 & 0.26 & 0.24 & 0.26 & 0.20 \\
\hline Variance: residual & 0.10 & 0.10 & 0.10 & 0.10 & 0.10 \\
\hline
\end{tabular}

Note: Dependent variable: 5 -year change in DIS index. ${ }^{* *} p<0.01,{ }^{*} p<0.05$ 
The results of these models, which can be found in Table 4.4, lend support to Hypothesis 1: increased IO membership is associated with an increased probability of subsequent backsliding. The coefficients on the main independent variables are all statistically significant in the expected direction. Since these are linear OLS models, the coefficient on the main independent variable can be interpreted as the amount of movement along the DIS scale associated with joining one additional IO. To illustrate this in more substantive terms, consider Hungary and Poland. Between 2009, right before Fidesz came to power, and 2017, Hungary's DIS score dropped by about 0.8. Similarly, Poland's DIS score between 2014, right before the Law and Justice party was elected, and 2017, dropped by .88. The coefficients on the main independent variables in the models in Table 4.4 are between 0.1 and 0.2 . In other words, by joining one additional IO, a state's level of democracy decreases by between $12-25 \%$ of the overall decline that has occurred in Hungary since 2010 and Poland since 2014.

As expected, I find states with larger GDPs are less likely to backslide, while states with higher levels of ethnic fractionalization are more likely. I also find states with higher prior DIS scores are more susceptible to backsliding. This may be because states where democracy was previously relatively high have more areas in which to regress compared to states that were only minimally democratic to begin with. In addition, oil income is positively associated with democratic progress.

Globalization and international factors in general, rather than IOs specifically, may create challenges for institutions in developing democracies and contribute to backsliding. I test for this empirically by estimating additional models that control for two proxies for globalization: trade openness and foreign direct investment inflow (World Bank, 2017). In addition, I include an indicator for whether an observation occurs following the end of the Cold War, which marks a significant shift in the international system as a whole and also in the extent to which international actors 
influence domestic democratic outcomes. The results in Table 4.4 are robust to the inclusion of these globalization variables. ${ }^{13}$

In addition, there is the possibility of reverse causality: are new democracies that are more susceptible to democratic backsliding joining IOs in an attempt to guard against future democratic erosion, but subsequently backsliding nonetheless? I contend that this is unlikely, for several reasons. First, research finds that all new democracies join IOs at higher rates (Mansfield and Pevehouse, 2008). Furthermore, it is unlikely that states can accurately anticipate future backsliding since it is a process often initiated and controlled by elected officials. Executives are the individuals most likely to anticipate future backsliding and are also the primary actors in negotiating IO membership. Since democratic backsliding tends to increase executive power, it is improbable that these individuals would intentionally work to stop it from occurring. Nevertheless, I also control for this possibility empirically. As discussed in more detail below, I estimate two-stage Heckman selection models (Heckman, 1979), where the outcome models control for a state's propensity to join certain types of IOs. Controlling for any potential selection effects, I still find evidence linking IO membership to subsequent democratic backsliding.

\subsubsection{Robustness Checks}

The results from Table 4.4 are robust to a series of alternative specifications and robustness checks in addition to the country and year fixed effects models and models controlling for the international-level factors discussed above. First, since the time over which backsliding occurs can vary from one case to the next, I estimate models that consider the 3-, 7-, and 10-year changes in a state's level of democracy. Overall,

\footnotetext{
${ }^{13}$ See Appendix A.3.
} 
the results of these models are similar to those for the 5-year time period. ${ }^{14}$ As expected, I find that the impact of IO membership on states' democratic trajectories is relatively small in the short term (at the 3-year mark) but increases over time. In fact, the substantive impact of membership is overall the largest at the 7-year mark.

I also re-estimate the models that include international-level controls from Appendix A.3 for these 3-, 7-, and 10-year changes as well. ${ }^{15}$ Here, the findings suggest that the impact of IO membership on a state's democracy trajectory may be only within a certain time frame. In the 3-year models that include proxies for globalization, none of the coefficients on the main independent variables are statistically significant, suggesting that changes in regime score due to IO membership may take longer to observe. As with the 5-year international models reported in Appendix A.3, the 7-year models in Appendix A.5 all find that increased IO membership has a negative and significant impact on states' democratic trajectories. In fact, as was the case with the main models, these additional international models suggest the largest substantive relationship is at the 7-year mark. In the 10-year models, increased membership in democratically committed and democratic political or economic IOs still has a significant relationship with a state's democratic trajectory. Although the signs are in the expected direction, the coefficient on the main independent variables in the remaining three models are not significant at 10 years.

Because international democracy promotion became so much more prevalent following the end of the Cold War, I also re-estimate the models from Table 4.4 for two different time periods: the Cold War era (1945-1989) and the post-Cold War era (1990-2015). The results of these models, reported in Appendix A.6, suggest that

\footnotetext{
${ }^{14}$ See Appendix A.4.

${ }^{15}$ See Appendix A.5.
} 
my theory is unsurprisingly a largely post-Cold War phenomenon. None of the coefficients on the main independent variables are statistically significant in the models using data from 1945-1989. Although this is likely in part due to missing data, ${ }^{16}$ the results are unsurprising given that international democracy promotion did not truly begin until the end of the Cold War. This is reflected in the results for the 1990-2015 models, which are consistent with, and in some cases stronger than, the results reported in Table 4.4 .

Since my DIS index is a new measure, I re-estimate the models from Table 4.4 using the Liberal Democracy index from the Varieties of Democracy dataset as an alternative measure of democratic backsliding. This variable captures the extent to which a country constitutionally protects individual and minority rights, exhibits strong rule of law, has an independent judiciary, maintains institutional checks on executive power, and upholds free and fair elections (Coppedge et al., 2018); in other words, it picks up on many, though not all, of the characteristics I include in my definition of democratic backsliding. Using the Liberal Democracy index, I re-create the dependent variable and re-estimate the models from Table 4.4. The results with this alternative operationalization of democratic backsliding are similar to the main results in Table $4.4 .^{17}$

Next, not all states are equally likely to join IOs, and especially the types of IOs considered here. This creates a selection problem in that only certain types of states, which may not be representative of the entire population of developing democracies, are members of these organizations. To verify that selection bias is not driving the results, I estimate a two-stage selection model (Heckman, 1979). In the first step, I model the selection process with a probit model; I then use the predicted

\footnotetext{
${ }^{16}$ The maximum number of observations in the 1945-1989 models is 139.

${ }^{17}$ See Appendix A.7.
} 
probabilities from this model to calculate the inverse Mill's ratio, which I include as a control variable in the outcome model.

The first stage selection models estimate a new democracy's probability of joining different types of IOs. ${ }^{18}$ Following Poast and Urpelainen, I include several controls in these models (Poast and Urpelainen, 2015). First, I include indicators for four continents: the Americas, Asia, Europe, and Oceania, with Africa as the omitted category. I interact each continent indicator with year (scaled) to model regional trends in IO membership over time; this is to account for the regional nature of many IOs as well as their increased prevalence over time (Shanks et al., 1996). Finally, since young democracies are particularly likely to join IOs during their first five years as democracies (Mansfield and Pevehouse, 2006), I include an indicator for whether or not an observation occurs five years or less after a state first transitioned to democracy. ${ }^{19}$

The outcome models draw on Table 4.4 to estimate the impact of IO memberships on a state's subsequent democratic trajectory. In addition to the controls from Table 4.4, I also include the Mill's ratio, calculated using the predicted probabilities from the first stage selection models. These outcome models are estimated using ordinary least squares with robust standard errors (Bushway et al., 2007; Poast and Urpelainen, 2015). ${ }^{20}$ Controlling for potential selection effects, I still find evidence that membership in IOs is linked to subsequent democratic backsliding being more likely in new democracies.

Another potential source of selection bias may result from the fact that I have included only democracies in my dataset, which could create a centering effect. Therefore, I re-estimate the models from Table 4.4 with data including both developing

\footnotetext{
${ }^{18} \mathrm{I}$ estimate 5 selection models, one for each type of IO included in Table 4.4.

${ }^{19}$ I code democratic transitions as the year when a state's Polity score first changed from 5 or below to 6 or higher (Marshall et al., 2016).

${ }^{20}$ See Appendix A.8.
} 
democracies and anocracies, defined as any country-year with a Polity score greater than -5 . Essentially, then, in terms of developing states, these models only exclude fully autocratic states, such as North Korea, that are both not relevant to my theory, and also are highly unlikely to seek out membership in or actually join these IOs. Including these states that are somewhere between autocracy and democracy, and therefore may be on the verge of democratization, I find similar results to those reported in Table 4.4. ${ }^{21}$

In addition, there may be another type of bias in the sample of IOs. The European Union (EU) is arguably the IO most commonly associated with democracy promotion and the organization most likely to both increase executive power and constrain its member states' domestic policy space. This raises the concern that EU membership is largely driving the results in Table 4.4. Although this is less likely since the main models include varying intercepts for region, I nevertheless re-estimate the models from Table 4.4, excluding the EU membership altogether from the analysis. The results from Table 4.4 hold even when the EU is removed from the data. ${ }^{22}$

Finally, all of these results may simply be due to a spurious correlation between IO membership and democratic trajectories. If my theory is correct, in addition to a negative and significant relationship between IO membership and democratic changes, there should also be no relationship between membership in other types of IOs that are not linked to democratic outcomes and democratic trajectories in their member states. Therefore, I estimate several placebo models.

\footnotetext{
${ }^{21}$ See Appendix A.9.

${ }^{22}$ See Appendix A.10.
} 
Specifically, first I re-estimate the same models from Table 4.4 but with main independent variables that count the number of non-democratically committed, nonpolitical and non-economic, ${ }^{23}$ and minimalist (as opposed to interventionist) IOs a state was a member of 5 years prior. The results of these models, which can be found in Table A.18 in Appendix A.11, return mixed results. The first two models, which capture membership in non-democratic and non-political and non-economic IOs, still find a negative and significant relationship between increased membership in these irrelevant IOs and subsequent backsliding. However, as expected, the third model finds no significant relationship between membership in minimalist IOs and democratic trajectories.

One reason for these unexpected results, and for why these IOs that are theoretically irrelevant to democracy promotion appear to impact democratic trajectories, may be because membership in these IOs is serving as a proxy for other international factors that impact domestic regime outcomes. By not explicitly controlling for these other international-level factors, the models from Table A.18 in Appendix A.11 may be attributing more influence to these irrelevant IOs than they have in practice. Therefore, I re-estimate these placebo models to also include the globalization controls from above: foreign direct investment, trade openness, and a Cold War era indicator. These additional models are the same as those from Table A.4 in Appendix A.3 except the independent variables are membership counts in non-democratic, non-political or non-economic, and minimalist IOs. The results of these models suggest additional support for the theory: once these other international-level factors are included in the model, there is no significant relationship between membership in irrelevant IOs and democratic trajectories in new democracies. ${ }^{24}$

\footnotetext{
${ }^{23}$ This includes "technical" and "other" IOs, such as those focused on aviation, statistics, sanitation and health, or research (Poast and Urpelainen, 2015).

${ }^{24}$ See Appendix A.11.
} 


\subsubsection{Extension: Variation in IO Democracy Promoting Tools}

The democratically committed IOs listed in Table 4.1 and included in the models in Table 4.4, in addition to varying with respect to levels of institutionalization (minimalist or interventionist), scope of membership (regional or universal), and functional orientations (political or economic), also differ with respect to the tools they use to promote democracy. While some rely exclusively on verbal support for democracy, others employ a variety of tools to promote democracy, including sending election monitors, providing financial or technical assistance to support developing democratic institutions, and membership conditionality.

Since these different types of democracy promotion likely impact states in different ways, I manually code the democratically committed IOs from Table 4.1 according to the type(s) of democracy promoting tools they use in order to further test my theory. Using information from each IO's official website, and other related online sources when available, I code whether or not each of these organizations use election-related assistance, technical (non-financial assistance), financial democracy assistance, negative membership conditionality, and/or positive membership conditionality. Often, individual organizations will use more than one of these tools simultaneously.

Election assistance includes both election monitors and assistance with other election-related institutions, such as voter registries. Technical assistance is nonmonetary aid directed at democratic institutions other than elections. For example, the Organization for Security and Cooperation in Europe's (OSCE) Office for Democratic Institutions and Human Rights conducts field operations to support democratic institutions, including running public information campaigns and providing non-partisan forums to encourage collaboration among political actors. Another common form of democracy promotion used by IOs is financial assistance directed toward democratic institutions. Finally, some IOs use membership conditionality as a means 
of democracy promotion. Positive conditionality consists of cases where IOs specify a range of conditions states must meet in order to join the organization, while negative conditionality consists of sanctions that these IOs use to punish member states who fail to comply with democratic membership conditions. Figure 4.1 shows the number of organizations that use each of these tools to promote democracy.

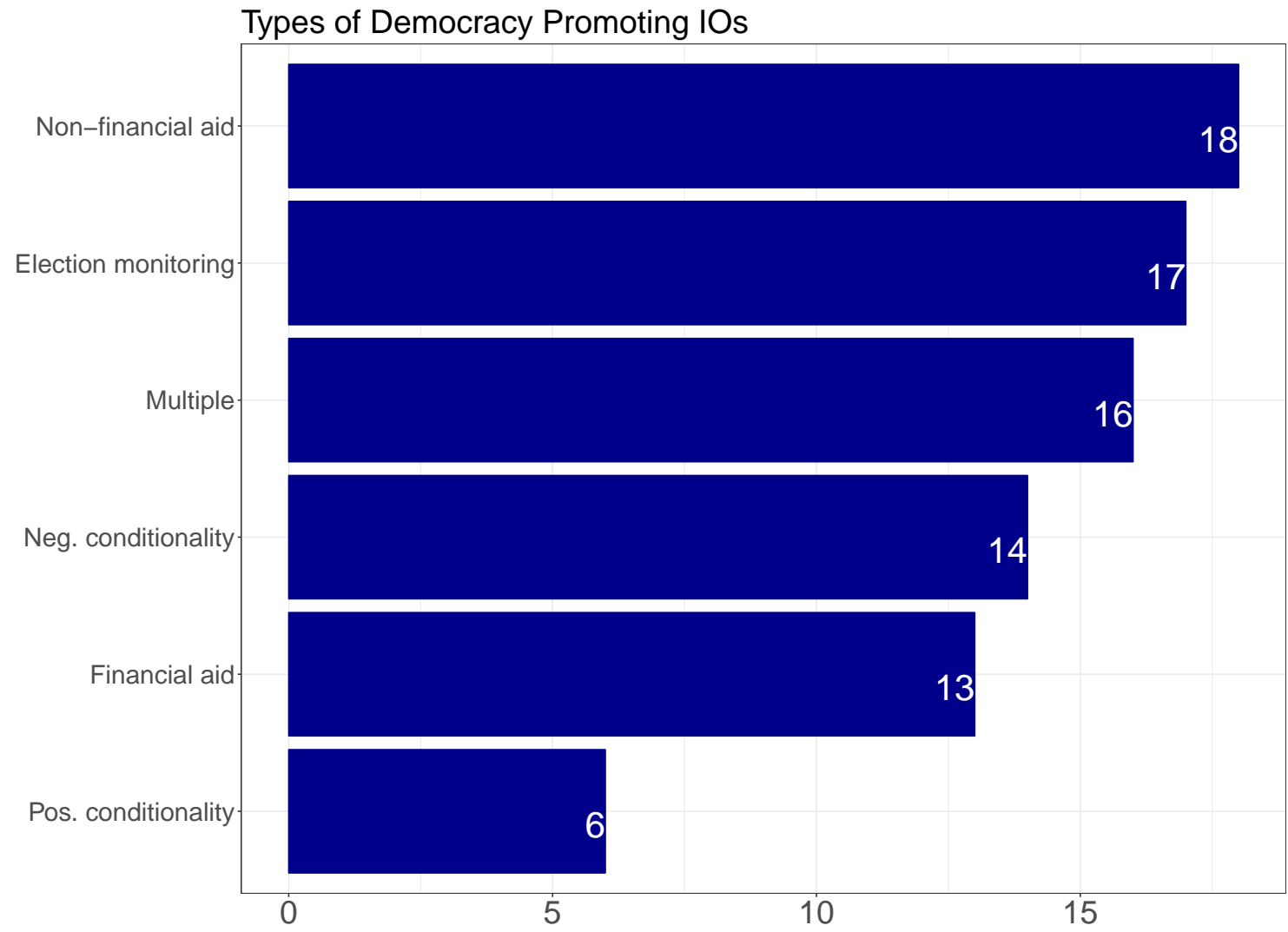

Figure 4.1: Democratically committed international organizations use a range of tools to promote democracy among their member states. 
Table 4.5: Types of Democracy Promotion and Democratic Backsliding. Varying Intercepts by Country and Region

\begin{tabular}{lccccc}
\hline & Elec. IO & Tech. Aid IO & Fin. Aid IO & Neg. Cond. IO & Pos. Cond. IO \\
\hline Num. IO memberships 5 years prior & $-0.07^{* *}$ & $-0.08^{* *}$ & -0.01 & -0.02 & 0.02 \\
& $(0.02)$ & $(0.03)$ & $(0.02)$ & $(0.03)$ & $(0.02)$ \\
GDP pc $(\log )$ & $0.44^{* * *}$ & $0.45^{* * *}$ & $0.40^{* * *}$ & $0.41^{* * *}$ & $0.38^{* * *}$ \\
& $(0.05)$ & $(0.05)$ & $(0.05)$ & $(0.05)$ & $(0.05)$ \\
GDP growth pc & $-0.04^{* *}$ & $-0.04^{* *}$ & $-0.04^{*}$ & $-0.04^{*}$ & $-0.04^{*}$ \\
& $(0.01)$ & $(0.01)$ & $(0.01)$ & $(0.01)$ & $(0.01)$ \\
DIS index & $-1.97^{* * *}$ & $-1.96^{* * *}$ & $-1.97^{* * *}$ & $-1.97^{* * *}$ & $-1.97^{* * *}$ \\
& $(0.03)$ & $(0.03)$ & $(0.03)$ & $(0.03)$ & $(0.03)$ \\
Effec. num. parties $(\log )$ & 0.02 & 0.02 & 0.02 & 0.02 & 0.02 \\
& $(0.02)$ & $(0.02)$ & $(0.02)$ & $(0.02)$ & $(0.02)$ \\
State age (log) & -0.02 & -0.02 & -0.03 & -0.04 & -0.04 \\
& $(0.03)$ & $(0.03)$ & $(0.03)$ & $(0.03)$ & $(0.03)$ \\
Internal conflict & 0.01 & 0.01 & 0.01 & 0.01 & 0.01 \\
& $(0.01)$ & $(0.01)$ & $(0.01)$ & $(0.01)$ & $(0.01)$ \\
Oil income pc & $1.00^{* * *}$ & $0.95^{* * *}$ & $1.01^{* * *}$ & $1.00^{* * *}$ & $1.01^{* * *}$ \\
& $(0.17)$ & $(0.17)$ & $(0.17)$ & $(0.17)$ & $(0.17)$ \\
Ethnic frac. & $-0.36^{* *}$ & $-0.36^{* *}$ & $-0.35^{* *}$ & $-0.35^{* *}$ & $-0.36^{* *}$ \\
& $(0.11)$ & $(0.11)$ & $(0.11)$ & $(0.11)$ & $(0.11)$ \\
Mean region DIS change & 0.01 & 0.00 & 0.01 & 0.01 & 0.01 \\
& $(0.01)$ & $(0.01)$ & $(0.01)$ & $(0.01)$ & $(0.01)$ \\
Lagged DV & $-0.03^{* *}$ & $-0.03^{* *}$ & $-0.02^{* *}$ & $-0.03^{* *}$ & $-0.02^{*}$ \\
& $(0.01)$ & $(0.01)$ & $(0.01)$ & $(0.01)$ & $(0.01)$ \\
\hline AIC & 1130.70 & 1131.43 & 1140.63 & 1139.69 & 1140.02 \\
BIC & 1208.28 & 1209.01 & 1218.21 & 1217.27 & 1217.59 \\
Log. lik. & -550.35 & -550.72 & -555.32 & -554.85 & -555.01 \\
Observations & 1302 & 1302 & 1302 & 1302 & 1302 \\
Num. countries & 70 & 70 & 70 & 70 & 70 \\
Num. regions & 15 & 15 & 15 & 15 & 15 \\
Variance: countries & 0.78 & 0.79 & 0.80 & 0.79 & 0.80 \\
Variance: regions & 0.28 & 0.27 & 0.24 & 0.25 & 0.23 \\
Variance: residual & 0.10 & 0.10 & 0.10 & 0.10 & 0.10 \\
\hline
\end{tabular}

Note: Dependent variable: 5 -year change in DIS index. ${ }^{* * *} p<0.001,{ }^{* *} p<0.01,{ }^{*} p<0.05$ 
To further test Hypothesis 1, I re-estimate the models from Table 4.4 with main independent variables that count the number of these different types of democracy promoting IOs a state was a member of 5 years prior. The results of these models can be found in Table 4.5 .

Based on the results of these models, those democratic organizations that use election monitoring and/or non-financial technical assistance to promote democracy are largely driving the relationship between democratically committed IOs and (negative) democratic trajectories in new democracies. Since these are the two most common forms of democracy promotion used by IOs, these results are relatively unsurprising. However, they are also consistent with my theoretical expectations.

My theory argues that democracy promoting IOs, in addition to increasing executive power and constraining domestic policy, also indirectly contribute to backsliding by focusing resources on elections and executives at the expense of other important domestic democratic institutions needed for long-term democratic success. The election-monitoring IOs of course focus their democracy promoting efforts primarily on election-related institutions. Furthermore, technical assistance is often directed toward executives in particular and tends to be more bureaucratic than inherently democratic. When they provide technical assistance, these IOs substitute their own expertise and institutions for domestically grown ones. Poast and Urpelainen find that this helps leaders in new democracies provide public goods to citizens in cases where they might otherwise not be able (Poast and Urpelainen, 2018). While this may be beneficial for initial transitions to democracy, democracy involves more than bureaucratic functions; it also requires the exercise of democracy itself. By focusing on technical, bureaucratic capabilities rather than broad-based, democratic institutions, these IOs may be creating conditions conducive to backsliding. 
It is also noteworthy that there is no significant relationship between IOs that use financial assistance and membership conditionality and democratic trajectories in these new democracies. Conditionality in particular is theorized to be an especially powerful form of democracy promotion, as exemplified in particular by the EU's approach to democracy (Dimitrova and Pridham, 2004; Ekiert, 2008; Levitz and PopEleches, 2010; Noutcheva, 2016). Nevertheless, the results suggest that the impact of these strategies is neutral at best rather than positive and significant, as existing research would predict.

\subsection{Testing the Mechanisms}

The evidence presented above suggests membership in the IOs most commonly associated with democratization and democratic consolidation makes subsequent backsliding more likely in new democracies. I argue they do this indirectly by neglecting democratic institutions other than elites and elections and directly by augmenting the power of executives relative to other government institutions (Hypothesis 2) and by limiting the domestic policy space, which stunts institutional development (Hypothesis 3). In this section, I test and find support for these two direct mechanisms.

\subsubsection{Executive Power}

I measure executive power using the horizontal accountability index from the Varieties of Democracy dataset. This variable measures the strength of institutional checks that prevent abuses of executive power, including the legislature, judiciary, ombudsmen, and prosecutor and comptroller generals. ${ }^{25}$ Lower values indicate fewer

\footnotetext{
${ }^{25}$ Specifically, this index is created by aggregating the following measures: judicial constraints on the executive, an indicator for if a legislature exists, legislative constraints on the executive, the extent to which the legislature regularly questions the executive, the likelihood the legislature will investigate and produce an unfavorable decision against the executive in cases of illegal or unethical
} 
institutional constraints on the executive, or higher relative executive power. Since I am interested in how IOs change executive power in democracies, the dependent variable is the 5-year change in a state's relative executive power. I also estimate models that consider the 3-year change in relative executive power. Since increased executive power tends to be a precursor to democratic backsliding, I expect to see signs of growing executive power prior to democratic backsliding. My theory predicts that increased IO membership will correspond with a negative value for the dependent variable, indicating that institutional checks on executive power have decreased (or relative executive power has increased) over the previous 5 (or 3) years.

IOs increase executive power in several ways. They do so first by giving executives, who represent their country at the international level, power over domestic outcomes decided among executives within an IO. International opportunities for executives to make decisions unilaterally are most likely within IOs that are sufficiently institutionalized to influence domestic policy, and these opportunities increase as states join more of these organizations. Therefore, I estimate models where the main independent variables indicate the number of interventionist IOs a state was a member of 5 (or 3) years prior. Second, I consider political and economic IOs, which are more likely to make decisions among state representatives that impact substantive domestic policy outcomes in their member states. Finally, I combine these two characteristics and consider interventionist economic and political organizations as well.

I account for domestic institutional characteristics likely to influence executive power. First, I control for the number of years the chief executive has been in office, whether the executive's party has an absolute majority in houses with lawmaking activity, and a measure of how likely other state institutions are to investigate and report on illegal activities by the executive (Coppedge et al., 2018). 
powers (Cruz et al., 2016), ${ }^{26}$ and a state's level of executive power at $t-5$ (or $t-3$ ), using the horizontal accountability index. I also include an indicator for if a state was involved in either an internal or external conflict, as conflict is often used as a justification for increasing executive power (Allansson et al., 2017; Gleditsch et al., 2002). Next, I control for oil income per capita. One of the proposed mechanisms linking natural resources to autocracy is increased incentives for politicians to dismantle state institutions to extract rents; as such, oil income may be associated with fewer institutional checks on the executive (Ross, 2015; Ross and Mahdavi, 2015). I also control for GDP per capita (logged) and GDP growth per capita (Feenstra et al., 2015), a state's DIS index (Coppedge et al., 2018), and state age (logged) (Correlates of War Project, 2016).

Finally, I include the 5- (or 3-) year lag of the dependent variable as a predictor. Each independent variable is lagged by 5 or 3 years, as appropriate. Summary statistics can be found in Table 4.6. As before, the universe of cases is new democracies from 1946-2015, and I estimate multilevel models with varying intercepts by country and region. All variables are standardized, and the the results can be found in Table 4.7. Overall, I find evidence in support of Hypothesis 2: membership in interventionist and/or political and economic IOs is linked to subsequent increases in relative executive power.

\footnotetext{
${ }^{26}$ Since the dependent variable is change in checks on executive power, I expect these institutional characteristics at time $t-5$ (or $t-3$ ) to influence the subsequent shifts in executive power. Because executive power is measured as institutional checks, a shift to a new executive during that time period is unlikely to alter the institutional distribution of power within a country.
} 
Table 4.6: Summary Statistics. Executive Power

\begin{tabular}{lrrrrc}
\hline \hline Statistic & $\mathrm{N}$ & Mean & St. Dev. & \multicolumn{1}{c}{ Min } & Max \\
\hline Horizontal account. index (5-year change) & 2,357 & 0.16 & 0.50 & -1.62 & 2.82 \\
Horizontal account. index (3-year change) & 2,418 & 0.09 & 0.38 & -1.34 & 2.78 \\
Num. interven IO mems. & 2,513 & 14.46 & 4.77 & 0 & 24 \\
Num. pol/econ IO mems. & 2,513 & 21.44 & 8.33 & 0 & 39 \\
Num. pol/econ interven IO mems. & 2,513 & 10.59 & 4.14 & 0 & 20 \\
Num. fin. aid IO mems. & 2,010 & 4.21 & 3.94 & 1 & 30 \\
Executive years in office & 1,891 & 0.39 & 0.49 & 0 & 1 \\
Executive controls legislature & 1,955 & 0.24 & 0.27 & 0.00 & 0.89 \\
Government fractionalization & 2,512 & 0.85 & 0.62 & -1.41 & 2.43 \\
Horizontal account. index & 2,276 & 8.81 & 0.99 & 6.22 & 10.74 \\
GDP pc (logged) & 2,250 & 2.82 & 5.95 & -41.63 & 33.76 \\
GDP growth pc & 2,513 & 0.92 & 0.51 & -0.52 & 2.66 \\
DIS index & 2,513 & 3.80 & 1.22 & 0.00 & 5.29 \\
State age (logged) & 2,339 & 150.82 & 590.23 & 0.00 & $7,881.68$ \\
Oil income pc & 2,513 & 0.14 & 0.35 & 0 & 1 \\
\hline
\end{tabular}


Table 4.7: Number of IO Memberships and Checks on Executive Power

\begin{tabular}{|c|c|c|c|c|c|c|}
\hline & $\begin{array}{c}\text { Interven IO } \\
3 \text { years }\end{array}$ & $\begin{array}{c}\mathrm{Pol} / \text { Econ } \mathrm{IO} \\
3 \text { years }\end{array}$ & $\begin{array}{c}\text { Pol/Econ, Interven IO } \\
3 \text { years }\end{array}$ & $\begin{array}{c}\text { Interven IO } \\
5 \text { years }\end{array}$ & $\begin{array}{c}\mathrm{Pol} / \text { Econ } \mathrm{IO} \\
5 \text { years }\end{array}$ & $\begin{array}{c}\mathrm{Pol} / \text { Econ, Interven IO } \\
5 \text { years }\end{array}$ \\
\hline Num. IO memberships $x$ years prior & $\begin{array}{c}-0.19^{* *} \\
(0.08)\end{array}$ & $\begin{array}{c}-0.13^{* *} \\
(0.06)\end{array}$ & $\begin{array}{c}-0.12^{* *} \\
(0.06)\end{array}$ & $\begin{array}{l}-0.10 \\
(0.07)\end{array}$ & $\begin{array}{c}-0.16^{* * *} \\
(0.05)\end{array}$ & $\begin{array}{c}-0.11^{* *} \\
(0.05)\end{array}$ \\
\hline Exec. yrs. in office & $\begin{array}{c}0.20^{* * *} \\
(0.03)\end{array}$ & $\begin{array}{c}0.19^{* * *} \\
(0.03)\end{array}$ & $\begin{array}{c}0.19^{* * *} \\
(0.03)\end{array}$ & $\begin{array}{c}0.08^{* * *} \\
(0.02)\end{array}$ & $\begin{array}{c}0.08^{* * *} \\
(0.02)\end{array}$ & $\begin{array}{c}0.08^{* * *} \\
(0.02)\end{array}$ \\
\hline Exec. controls legis. & $\begin{array}{c}0.07^{* * *} \\
(0.02)\end{array}$ & $\begin{array}{c}0.07^{* * *} \\
(0.02)\end{array}$ & $\begin{array}{c}0.08^{* * *} \\
(0.02)\end{array}$ & $\begin{array}{c}0.10^{* * *} \\
(0.02)\end{array}$ & $\begin{array}{c}0.09^{* * *} \\
(0.02)\end{array}$ & $\begin{array}{c}0.10^{* * *} \\
(0.02)\end{array}$ \\
\hline Govt. fractionalization & $\begin{array}{c}-0.04^{*} \\
(0.02)\end{array}$ & $\begin{array}{c}-0.04^{*} \\
(0.02)\end{array}$ & $\begin{array}{l}-0.04 \\
(0.02)\end{array}$ & $\begin{array}{c}0.01 \\
(0.02)\end{array}$ & $\begin{array}{c}0.01 \\
(0.02)\end{array}$ & $\begin{array}{c}0.01 \\
(0.02)\end{array}$ \\
\hline Horizontal account. index & $\begin{array}{c}-1.46^{* * *} \\
(0.07)\end{array}$ & $\begin{array}{c}-1.46^{* * *} \\
(0.07)\end{array}$ & $\begin{array}{c}-1.46^{* * *} \\
(0.07)\end{array}$ & $\begin{array}{c}-1.42^{* * *} \\
(0.06)\end{array}$ & $\begin{array}{c}-1.41^{* * *} \\
(0.06)\end{array}$ & $\begin{array}{c}-1.41^{* * *} \\
(0.06)\end{array}$ \\
\hline GDP pc (log) & $\begin{array}{c}0.66^{* * *} \\
(0.07)\end{array}$ & $\begin{array}{c}0.67^{* * * *} \\
(0.08)\end{array}$ & $\begin{array}{c}0.65^{* * *} \\
(0.07)\end{array}$ & $\begin{array}{c}0.54^{* * *} \\
(0.06)\end{array}$ & $\begin{array}{c}0.61^{* * *} \\
(0.07)\end{array}$ & $\begin{array}{c}0.56^{* * *} \\
(0.06)\end{array}$ \\
\hline GDP growth pc & $\begin{array}{l}-0.00 \\
(0.02)\end{array}$ & $\begin{array}{l}-0.00 \\
(0.02)\end{array}$ & $\begin{array}{l}-0.00 \\
(0.02)\end{array}$ & $\begin{array}{c}0.02 \\
(0.02)\end{array}$ & $\begin{array}{c}0.02 \\
(0.02)\end{array}$ & $\begin{array}{c}0.01 \\
(0.02)\end{array}$ \\
\hline DIS index & $\begin{array}{c}-0.76^{* * *} \\
(0.10)\end{array}$ & $\begin{array}{c}-0.76^{* * *} \\
(0.10)\end{array}$ & $\begin{array}{c}-0.77^{* * *} \\
(0.10)\end{array}$ & $\begin{array}{c}-0.57^{* * *} \\
(0.08)\end{array}$ & $\begin{array}{c}-0.56^{* * *} \\
(0.08)\end{array}$ & $\begin{array}{c}-0.57^{* * *} \\
(0.08)\end{array}$ \\
\hline State age $(\log )$ & $\begin{array}{l}-0.04 \\
(0.05)\end{array}$ & $\begin{array}{l}-0.03 \\
(0.05)\end{array}$ & $\begin{array}{l}-0.04 \\
(0.05)\end{array}$ & $\begin{array}{c}0.01 \\
(0.05)\end{array}$ & $\begin{array}{c}0.03 \\
(0.05)\end{array}$ & $\begin{array}{c}0.02 \\
(0.05)\end{array}$ \\
\hline Oil income pc & $\begin{array}{c}0.24 \\
(0.27)\end{array}$ & $\begin{array}{c}0.25 \\
(0.27)\end{array}$ & $\begin{array}{c}0.25 \\
(0.27)\end{array}$ & $\begin{array}{l}0.42^{*} \\
(0.23)\end{array}$ & $\begin{array}{c}0.33 \\
(0.22)\end{array}$ & $\begin{array}{c}0.37 \\
(0.22)\end{array}$ \\
\hline Conflict (any) & $\begin{array}{c}0.00 \\
(0.02)\end{array}$ & $\begin{array}{c}0.00 \\
(0.02)\end{array}$ & $\begin{array}{c}0.00 \\
(0.02)\end{array}$ & $\begin{array}{c}0.01 \\
(0.02)\end{array}$ & $\begin{array}{c}0.01 \\
(0.02)\end{array}$ & $\begin{array}{c}0.01 \\
(0.02)\end{array}$ \\
\hline Lagged DV & $\begin{array}{l}-0.00 \\
(0.01)\end{array}$ & $\begin{array}{l}-0.00 \\
(0.01)\end{array}$ & $\begin{array}{l}-0.00 \\
(0.01)\end{array}$ & $\begin{array}{l}-0.01 \\
(0.01) \\
\end{array}$ & $\begin{array}{c}-0.02^{*} \\
(0.01)\end{array}$ & $\begin{array}{l}-0.02 \\
(0.01)\end{array}$ \\
\hline AIC & 3298.68 & 3300.39 & 3300.58 & 2429.16 & 2422.54 & 2426.47 \\
\hline $\mathrm{BIC}$ & 3385.42 & 3387.13 & 3387.32 & 2514.90 & 2508.29 & 2512.21 \\
\hline Log. lik. & -1633.34 & -1634.19 & -1634.29 & -1198.58 & -1195.27 & -1197.23 \\
\hline Observations & 1671 & 1671 & 1671 & 1570 & 1570 & 1570 \\
\hline Num. countries & 83 & 83 & 83 & 83 & 83 & 83 \\
\hline Num. regions & 17 & 17 & 17 & 17 & 17 & 17 \\
\hline Variance: countries & 1.27 & 1.21 & 1.24 & 1.01 & 0.94 & 0.98 \\
\hline Variance: regions & 0.06 & 0.08 & 0.06 & 0.06 & 0.08 & 0.06 \\
\hline Variance: residual & 0.33 & 0.33 & 0.33 & 0.21 & 0.21 & 0.21 \\
\hline
\end{tabular}

Note: Dependent variable: 5 -year change in Horizontal Accountability index. ${ }^{* * *} p<0.001,{ }^{* *} p<0.01,{ }^{*} p<0.05$ 


\subsubsection{Domestic Policy Space}

In addition to increasing executive power, IO membership can reduce state control over and potential alternatives to domestic policy. The limits that IOs place on domestic policy options can, in turn, make democratic backsliding more likely by stunting the development of political parties and legislatures and by limiting governments' abilities to provide public goods to citizens. As a result, horizontal checks on executive power are weakened, and elections are contested in a relative ideological void.

A state's domestic policy space consists of the range of possible policies political actors can adopt and implement. Since it is only possible to observe the policies actually implemented, it is difficult to directly measure a state's entire domestic policy space. Therefore, I rely on several observable implications of a limited domestic policy space to operationalize this concept.

IOs' influence on states' economic policies is particularly salient and well-documented (Andrews, 1994; Cao, 2009; Haggard and Maxfield, 1996; Mosley, 2000). Therefore, as an initial test of Hypothesis 3, which predicts that increased IO membership decreases states' domestic policy space, I focus specifically on the relationship between IO membership and domestic economic policy. A state's domestic policy space, economic and otherwise, consists of the range of possible policies that governments and political parties can adopt and implement. In a more expansive (democratic) domestic policy space, policy alternatives to the status quo are theoretically viable and are advocated by opposition parties and a minority of voters yet are unobservable in a single moment. If a state has control over its policy space, and therefore a wide range of policy options are possible, there should be evidence of policy compromises that represent the middle ground between alternative preferences or options. For example, if party $A$ advocates protectionism, but party $B$ prefers trade liberalization, 
there should be evidence of a compromise: the resulting trade policy will be neither fully protectionist nor purely open, but rather will fall somewhere in the middle. If a state's policy options are limited by IO membership requirements, however, there are few if any alternatives to the current policy, and those that exist will not diverge substantially. In other words, I use evidence of policy compromise as a proxy for domestic policy space: in states where domestic policy options are limited, there will be less evidence of or need for compromise since political actors cannot feasibly offer alternatives.

To measure this idea of compromise, I use the Fraser Economic Freedom of the World Index (Gwartney et al., 2017). ${ }^{27}$ This index encompasses measures of 11 different domestic economic policies and indicators: government consumption, government transfers and subsidies, government enterprises and investment, levels of top marginal tax rate, money growth, inflation variability, inflation rate, freedom to own foreign bank accounts, credit regulations, labor regulations, and business regulations. Each of these dimensions is on a 0 to 10 scale and is equally weighted. At one extreme is a quintessentially neoliberal state with no government involvement in the economy; the other end of the scale indicates, essentially, a planned economy where the government controls or regulates all economic policy.

Building on the idea that compromise between opposing political actors, such as parties, on policy outcomes signals a more expansive domestic policy space, I argue that states at or close to the extremes along this index have a more limited domestic policy space; states that score a 5, on the other hand, represent a wide policy space characterized by compromise between opposing preferences and options. Therefore, to measure domestic policy space, I calculate the absolute distance between a state's Economic Freedom Index and 5. I rescale the resulting variable so that lower

\footnotetext{
${ }^{27}$ Cao uses this index to test the extent to which shared membership in IOs is linked to policy convergence between states (Cao, 2009).
} 
values indicate a more limited domestic policy space. Drawing on Table 4.4, the dependent variable is the 5-year change in a state's domestic policy space; negative values indicate that a state's policy space has decreased, positive ones indicate it has increased, and 0 signifies no change. If my theory is correct, membership in IOs should be associated with a subsequent negative value for this variable.

Since the dependent variable measures domestic economic policy space specifically, I focus on the political and economic IOs discussed above. In addition, to isolate IOs that are most likely to require and have the tools to enforce policy changes, I also consider interventionist IOs. The main independent variables are counts of the political or economic, interventionist, and political or economic interventionist IOs a state was a member of 5 years prior.

I control for factors likely to impact states' economic policies and relations between ruling and opposition parties. First, I control for GDP per capita (logged), GDP growth per capita, state age (Feenstra et al., 2015; Correlates of War Project, 2016), and a state's DIS index (Coppedge et al., 2018; Przeworski and Limongi, 1997). Next, I include an indicator for whether the executive is from a party categorized as a "left" party with respect to economic policy. Since the extent to which compromise on policies is necessary is closely linked to political parties, I control for the effective number of political parties (Cruz et al., 2016). I also account for oil income, since this may influence the types of economic policies governments prefer (Ross and Mahdavi, 2015), and for two international economic variables: trade openness and foreign direct investment inflow (World Bank, 2017). I also include a 5-year lag of the dependent variable and a state's Fraser index at time $t-5$ as controls. Summary statistics for the variables used in these and other models in this domestic policy space section can be found in Table 4.8. 
Table 4.8: Summary Statistics. Domestic Policy Space

\begin{tabular}{lrrrrr}
\hline \hline Statistic & $\mathrm{N}$ & Mean & St. Dev. & Min & Max \\
\hline Fraser compromise index (5-year change) & 923 & -0.14 & 0.44 & -2.45 & 1.68 \\
Inflation rate (5-year change) & 2,064 & -9.97 & 587.93 & $-13,591.25$ & $12,313.61$ \\
Distinct party platforms (5-year change) & 2,349 & 0.13 & 0.50 & -1.18 & 4.46 \\
Num. pol/econ IO mems. & 2,513 & 21.44 & 8.33 & 0 & 39 \\
Num. interven IO mems. & 2,513 & 14.46 & 4.77 & 0 & 24 \\
Num. pol/econ interven IO mems. & 2,513 & 6.38 & 2.17 & 0 & 10 \\
GDP pc (logged) & 2,276 & 8.81 & 0.99 & 6.22 & 10.74 \\
GDP growth pc & 2,250 & 2.82 & 5.95 & -41.63 & 33.76 \\
DIS index & 2,513 & 0.92 & 0.51 & -0.52 & 2.66 \\
Fraser economic freedom index & 1,252 & 2.15 & 0.72 & 0.73 & 3.88 \\
Inflation rate & 2,252 & 41.41 & 370.41 & -36.52 & $12,338.66$ \\
Distinct party platforms & 2,512 & 1.29 & 1.00 & -1.92 & 3.27 \\
Effective number of parties (logged) & 1,645 & 6.08 & 0.76 & 1.61 & 6.55 \\
State age (logged) & 2,513 & 3.80 & 1.22 & 0.00 & 5.29 \\
Executive "left" party indicator & 1,668 & 0.33 & 0.47 & 0 & 1 \\
Oil income pc & 2,339 & 150.82 & 590.23 & 0.00 & $7,881.68$ \\
Trade openness & 2,227 & 73.60 & 37.20 & 5.73 & 311.36 \\
FDI inflow & 2,086 & 3.49 & 8.13 & -43.46 & 198.07 \\
Electoral system type & 2,026 & 0.24 & 0.43 & 0 & 1 \\
Presidential vs. parliamentary & 2,070 & 1.83 & 0.95 & 1 & 3 \\
Urbanization level & 2,341 & 52.80 & 21.52 & 4.44 & 95.31 \\
\hline
\end{tabular}


As before, the universe of cases is new democracies. The Fraser Economic Freedom data begin in 1970, however, so these models only include observations from 1970 to 2015. I estimate multilevel models with varying intercepts by country and region. All variables are lagged by 5 years and standardized to facilitate interpretation. The results can be found in Table 4.9 .

I find preliminary evidence linking IO membership to a diminished economic policy space: as the number of interventionist and political or economic interventionist IOs a state is a member of increases, its economic policy index subsequently moves further toward the extremes, signaling less compromise among political actors with respect to policy outcomes. This suggests that states in more interventionist economic and political IOs have fewer economic policy alternatives from which to choose.

These results are robust to models that use a more conventional measure of economic policy: inflation rates. Mosley finds that international financial actors are particularly attentive to states' monetary policies, including inflation rates (Mosley, 2000). Therefore, as an additional measure of domestic economic policy space, I use the 5-year change in a state's inflation rate as the dependent variable, predicting that economic policy pressure from IOs will drive governments to have lower inflation rates (World Bank, 2017). I re-estimate the models from Table 4.9 using this alternative dependent variable; the results can be found in Table 4.10. Here again I find a significant relationship in the expected direction: additional IO memberships correspond with subsequent decreases in inflation rates in new democracies.

Although economic policy is a large part of any domestic policy space, there are other policy topics included in this concept. Therefore, I propose a third way to measure the domestic policy space. In mature democracies with developed party systems, parties appeal to voters in part by distinguishing themselves from one another by taking distinct positions on various policy issues (Lipset and Rokkan, 1967). However, 
Table 4.9: Number of IO Memberships and Domestic Policy Space. Fraser Compromise Index

\begin{tabular}{|c|c|c|c|}
\hline & Interven IO & $\mathrm{Pol} /$ Econ IO & $\mathrm{Pol} /$ Econ, Interven IO \\
\hline Num. IO memberships 5 years prior & $\begin{array}{c}-0.58^{* * *} \\
(0.20)\end{array}$ & $\begin{array}{l}-0.12 \\
(0.13)\end{array}$ & $\begin{array}{c}-0.68^{* * *} \\
(0.17)\end{array}$ \\
\hline GDP pc (logged) & $\begin{array}{l}-0.05 \\
(0.14)\end{array}$ & $\begin{array}{l}-0.13 \\
(0.13)\end{array}$ & $\begin{array}{l}-0.06 \\
(0.14)\end{array}$ \\
\hline GDP growth pc & $\begin{array}{c}-0.12^{*} \\
(0.07)\end{array}$ & $\begin{array}{c}-0.14^{* *} \\
(0.07)\end{array}$ & $\begin{array}{c}-0.13^{*} \\
(0.07)\end{array}$ \\
\hline DIS index & $\begin{array}{c}-0.41^{* * *} \\
(0.15)\end{array}$ & $\begin{array}{c}-0.40^{* * *} \\
(0.15)\end{array}$ & $\begin{array}{c}-0.40^{* * *} \\
(0.15)\end{array}$ \\
\hline Fraser economic index & $\begin{array}{c}-0.94^{* * *} \\
(0.08)\end{array}$ & $\begin{array}{c}-0.90^{* * *} \\
(0.08)\end{array}$ & $\begin{array}{c}-1.01^{* * *} \\
(0.08)\end{array}$ \\
\hline Effec. num. parties (log) & $\begin{array}{c}0.02 \\
(0.06)\end{array}$ & $\begin{array}{c}0.04 \\
(0.06)\end{array}$ & $\begin{array}{c}0.03 \\
(0.06)\end{array}$ \\
\hline State age $(\log )$ & $\begin{array}{c}0.06 \\
(0.12)\end{array}$ & $\begin{array}{l}-0.04 \\
(0.12)\end{array}$ & $\begin{array}{c}0.02 \\
(0.12)\end{array}$ \\
\hline Executive "left" party indicator & $\begin{array}{c}0.06 \\
(0.05)\end{array}$ & $\begin{array}{c}0.05 \\
(0.05)\end{array}$ & $\begin{array}{c}0.06 \\
(0.05)\end{array}$ \\
\hline Oil income pc & $\begin{array}{l}1.02^{*} \\
(0.56)\end{array}$ & $\begin{array}{l}1.29^{* *} \\
(0.55)\end{array}$ & $\begin{array}{c}0.73 \\
(0.58)\end{array}$ \\
\hline Trade openness & $\begin{array}{c}-0.29^{* * *} \\
(0.11)\end{array}$ & $\begin{array}{c}-0.24^{* *} \\
(0.10)\end{array}$ & $\begin{array}{c}-0.26^{* *} \\
(0.11)\end{array}$ \\
\hline FDI inflow & $\begin{array}{l}-0.02 \\
(0.03)\end{array}$ & $\begin{array}{l}-0.01 \\
(0.04)\end{array}$ & $\begin{array}{l}-0.01 \\
(0.03)\end{array}$ \\
\hline Lagged DV & $\begin{array}{c}0.06 \\
(0.04)\end{array}$ & $\begin{array}{c}0.05 \\
(0.04)\end{array}$ & $\begin{array}{c}0.06 \\
(0.04)\end{array}$ \\
\hline $\mathrm{AIC}$ & 1268.15 & 1276.60 & 1262.87 \\
\hline $\mathrm{BIC}$ & 1334.90 & 1343.35 & 1329.62 \\
\hline Log. lik. & -618.08 & -622.30 & -615.44 \\
\hline Observations & 479 & 479 & 479 \\
\hline Num. countries & 64 & 64 & 64 \\
\hline Num. regions & 15 & 15 & 15 \\
\hline Variance: countries & 0.17 & 0.16 & 0.20 \\
\hline Variance: regions & 0.07 & 0.08 & 0.09 \\
\hline Variance: residual & 0.62 & 0.63 & 0.60 \\
\hline
\end{tabular}


Table 4.10: Number of IO Memberships and Domestic Policy Space. Inflation Rate

\begin{tabular}{|c|c|c|c|}
\hline & Interven IO & $\mathrm{Pol} /$ Econ IO & Pol/Econ, Interven IO \\
\hline Num. IO memberships 5 years prior & $\begin{array}{c}-0.21^{* * *} \\
(0.07)\end{array}$ & $\begin{array}{c}-0.14^{* * *} \\
(0.05)\end{array}$ & $\begin{array}{c}-0.21^{* * *} \\
(0.06)\end{array}$ \\
\hline GDP pc (logged) & $\begin{array}{c}0.07 \\
(0.05)\end{array}$ & $\begin{array}{c}0.04 \\
(0.05)\end{array}$ & $\begin{array}{c}0.06 \\
(0.04)\end{array}$ \\
\hline GDP growth pc & $\begin{array}{l}-0.03 \\
(0.03)\end{array}$ & $\begin{array}{l}-0.02 \\
(0.03)\end{array}$ & $\begin{array}{l}-0.03 \\
(0.03)\end{array}$ \\
\hline DIS index & $\begin{array}{c}-0.15^{* * *} \\
(0.05)\end{array}$ & $\begin{array}{c}-0.16^{* * *} \\
(0.05)\end{array}$ & $\begin{array}{c}-0.15^{* * *} \\
(0.05)\end{array}$ \\
\hline Inflation rate & $\begin{array}{c}-0.93^{* * *} \\
(0.03)\end{array}$ & $\begin{array}{c}-0.93^{* * *} \\
(0.04)\end{array}$ & $\begin{array}{c}-0.93^{* * *} \\
(0.03)\end{array}$ \\
\hline Effec. num. parties (log) & $\begin{array}{l}-0.02 \\
(0.03)\end{array}$ & $\begin{array}{l}-0.01 \\
(0.03)\end{array}$ & $\begin{array}{l}-0.01 \\
(0.03)\end{array}$ \\
\hline State age $(\log )$ & $\begin{array}{l}0.10^{* *} \\
(0.05)\end{array}$ & $\begin{array}{c}0.07 \\
(0.05)\end{array}$ & $\begin{array}{l}0.08^{*} \\
(0.04)\end{array}$ \\
\hline Executive "left" party indicator & $\begin{array}{l}-0.02 \\
(0.02)\end{array}$ & $\begin{array}{l}-0.03 \\
(0.02)\end{array}$ & $\begin{array}{l}-0.03 \\
(0.02)\end{array}$ \\
\hline Oil income pc & $\begin{array}{l}-0.21 \\
(0.22)\end{array}$ & $\begin{array}{l}-0.16 \\
(0.22)\end{array}$ & $\begin{array}{l}-0.27 \\
(0.22)\end{array}$ \\
\hline Trade openness & $\begin{array}{l}-0.04 \\
(0.04)\end{array}$ & $\begin{array}{l}-0.03 \\
(0.04)\end{array}$ & $\begin{array}{l}-0.02 \\
(0.04)\end{array}$ \\
\hline FDI inflow & $\begin{array}{l}-0.00 \\
(0.03)\end{array}$ & $\begin{array}{l}-0.00 \\
(0.03)\end{array}$ & $\begin{array}{c}0.00 \\
(0.03)\end{array}$ \\
\hline Lagged DV & $\begin{array}{c}0.03 \\
(0.03) \\
\end{array}$ & $\begin{array}{c}0.03 \\
(0.03) \\
\end{array}$ & $\begin{array}{c}0.03 \\
(0.03) \\
\end{array}$ \\
\hline $\mathrm{AIC}$ & 2847.82 & 2849.85 & 2843.80 \\
\hline BIC & 2930.21 & 2932.24 & 2926.18 \\
\hline Log. lik. & -1407.91 & -1408.93 & -1405.90 \\
\hline Observations & 1273 & 1273 & 1273 \\
\hline Num. countries & 69 & 69 & 69 \\
\hline Num. regions & 15 & 15 & 15 \\
\hline Variance: countries & 0.01 & 0.01 & 0.01 \\
\hline Variance: regions & 0.00 & 0.01 & 0.01 \\
\hline Variance: residual & 0.51 & 0.50 & 0.50 \\
\hline
\end{tabular}


it is more difficult for parties to do this when the range of viable policy options is constrained. Instead, they define themselves in terms of populism or broadly appealing valence issues, such as support for anti-corruption, nationalism, or rule of law (Kitschelt et al., 1999; Ward et al., 2015). Thus, another observable implication of a limited domestic policy space is convergence across party platforms. As an additional test of the impact of IOs on domestic policy space, I consider the relationship between IO memberships and party platform convergence.

In these models, the dependent variable is the 5-year change in the distinctness of party platforms within a state, a measure taken from the Varieties of Democracy dataset. This variable takes into account how many parties in the national legislature or presidency have made their platforms, or manifestos, publicly available and, more importantly, the extent to which these manifestos are relatively distinct in terms of content or ideology across parties. This variable is coded on a five-point ordinal scale (that is converted to an interval variable by the measurement model), where 0 indicates none or nearly none of the parties have platforms and/or none have platforms distinct from other parties, and 5 indicates that all or nearly all have publicly available and distinct manifestoes (Coppedge et al., 2018). I argue that higher values along this variable indicate states where parties have a wider range of policy options to adopt and debate, or a more expansive domestic policy space. Therefore, a negative change in a state's measure of distinct party platforms indicates convergence across parties over the previous 5 years, or a diminished domestic policy space.

As before, the main independent variables are states' membership counts in different types of IOs 5 years prior. I control for factors likely to influence party platforms and ideological development, including GDP and GDP growth per capita (Feenstra et al., 2015), a state's electoral system type (plurality or proportional representation) and government structure (presidential or parliamentary) (Cruz et al., 2016), urban 
population as a percent of the total population (World Bank, 2017), state age (Correlates of War Project, 2016), and the DIS index (Coppedge et al., 2018). I also include the party distinctness variable and the dependent variable at $t-5$ as controls. I estimate multilevel models with varying intercepts by country and region, focusing on new democracies between 1946 and 2015. All variables are standardized and lagged by 5 years, and the results can be found in Table 4.11. I find further evidence that IOs limit states' domestic policy spaces: membership in interventionist and political or economic IOs is associated with subsequent decreases in the dependent variable, or convergence in party platforms within a country. Although the main independent variable in the third model in Table 4.11 is not significant, the sign is in the expected direction.

Overall, I find support for my theory: membership in democratically committed, political or economic, and interventionist IOs is linked to subsequent democratic backsliding in new democracies. I also find evidence that the proposed theoretical mechanisms - increased executive power and weak institutions resulting from diminished domestic policy options - might account for this relationship. 
Table 4.11: Number of IO Memberships and Domestic Policy Space. Distinct Party Platforms

\begin{tabular}{|c|c|c|c|}
\hline & Interven IO & $\mathrm{Pol} /$ Econ IO & $\mathrm{Pol} /$ Econ, Interven IO \\
\hline Num. IO memberships & $\begin{array}{c}-0.23^{* * *} \\
(0.06)\end{array}$ & $\begin{array}{c}-0.20^{* * *} \\
(0.05)\end{array}$ & $\begin{array}{l}-0.06 \\
(0.05)\end{array}$ \\
\hline GDP pc (logged) & $\begin{array}{c}0.42^{* * *} \\
(0.07)\end{array}$ & $\begin{array}{c}0.48^{* * *} \\
(0.07)\end{array}$ & $\begin{array}{c}0.40^{* * *} \\
(0.07)\end{array}$ \\
\hline GDP growth pc & $\begin{array}{c}0.05^{* * *} \\
(0.02)\end{array}$ & $\begin{array}{c}0.05^{* * *} \\
(0.02)\end{array}$ & $\begin{array}{c}0.05^{* * *} \\
(0.02)\end{array}$ \\
\hline DIS index & $\begin{array}{l}-0.02 \\
(0.04)\end{array}$ & $\begin{array}{l}-0.01 \\
(0.04)\end{array}$ & $\begin{array}{l}-0.05 \\
(0.04)\end{array}$ \\
\hline Electoral system type & $\begin{array}{c}0.18^{* * *} \\
(0.04)\end{array}$ & $\begin{array}{c}0.19^{* * *} \\
(0.04)\end{array}$ & $\begin{array}{c}0.18^{* * *} \\
(0.04)\end{array}$ \\
\hline Pres. vs. parl. & $\begin{array}{c}0.02 \\
(0.04)\end{array}$ & $\begin{array}{c}0.02 \\
(0.04)\end{array}$ & $\begin{array}{c}0.01 \\
(0.04)\end{array}$ \\
\hline Urban. level & $\begin{array}{c}0.25^{* * *} \\
(0.08)\end{array}$ & $\begin{array}{c}0.24^{* * *} \\
(0.08)\end{array}$ & $\begin{array}{l}0.17^{* *} \\
(0.08)\end{array}$ \\
\hline Distinct party platforms & $\begin{array}{c}-1.73^{* * *} \\
(0.03)\end{array}$ & $\begin{array}{c}-1.72^{* * *} \\
(0.03)\end{array}$ & $\begin{array}{c}-1.72^{* * *} \\
(0.03)\end{array}$ \\
\hline State age $(\log )$ & $\begin{array}{l}0.09^{* *} \\
(0.05)\end{array}$ & $\begin{array}{l}0.10^{* *} \\
(0.05)\end{array}$ & $\begin{array}{c}0.07 \\
(0.05)\end{array}$ \\
\hline Lagged DV & $\begin{array}{l}0.03^{* *} \\
(0.01)\end{array}$ & $\begin{array}{l}0.03^{* *} \\
(0.01) \\
\end{array}$ & $\begin{array}{c}0.04^{* * * *} \\
(0.01) \\
\end{array}$ \\
\hline AIC & 3016.78 & 3013.03 & 3029.66 \\
\hline $\mathrm{BIC}$ & 3093.74 & 3089.98 & 3106.62 \\
\hline Log. lik. & -1494.39 & -1492.51 & -1500.83 \\
\hline Observations & 1802 & 1802 & 1802 \\
\hline Num. countries & 85 & 85 & 85 \\
\hline Num. regions & 17 & 17 & 17 \\
\hline Variance: countries & 1.23 & 1.19 & 1.24 \\
\hline Variance: regions & 0.77 & 0.69 & 0.83 \\
\hline Variance: residual & 0.24 & 0.24 & 0.24 \\
\hline
\end{tabular}




\section{Chapter 5: Democratic Backsliding in the European Union}

Democracy promotion is increasingly occurring under the auspices of international organizations (IOs), with observers finding IOs are positive forces for democracy (Donno, 2013a; Genna and Hiroi, 2014; Grigorescu, 2003; Pevehouse, 2005; Poast and Urpelainen, 2018). The European Union (EU) in particular is associated with democracy promotion. In addition to being composed entirely of democratic states, the EU has adopted extensive mechanisms for promoting democracy via integration and is historically viewed as unrivaled in its ability to promote transitions to democracy and democratic consolidation in its member states. Indeed, the EU is often cited as the IO with the greatest ability to influence regime outcomes, with a particular emphasis on its role in supporting democratization and democratic consolidation in Spain, Portugal, and Greece in the 1970s and 1980s (Smith, 2001), and especially in Central and Eastern Europe following the end of the Cold War (Dimitrova and Pridham, 2004; Ekiert, 2008; Levitz and Pop-Eleches, 2010; Noutcheva, 2016).

Nevertheless, despite the its purported qualifications for promoting democracy, there has been recent evidence of democratic backsliding within the EU's borders. Hungary is a prominent example. Throughout the 1990s, Hungary was viewed as the model of post-communist democratization success. However, in 2010, the Fidesz party, led by Viktor Orbán, won a two-thirds majority in the Hungarian Parliament, which it continues to hold in 2019. In the eight years since coming to power, the Orbán 
government has eroded or dismantled a number of institutions. For example, in 2012 they completely rewrote the Hungarian constitution and, in the process, eliminated a number of checks on executive power. They have also taken steps to undermine the independence of the judiciary and the media. In 2018, Hungary passed a law criminalizing efforts by non-governmental organizations providing humanitarian aid to refugees in Hungary, and more recently it has jeopardized academic freedom by banning gender studies programs and effectively shutting down Central European University in Budapest.

The EU has done little in response to Hungary's backsliding. Of course, in order to join the EU initially, which it did in 2004, Hungary had to meet a series of democratic criteria. However, over the subsequent eight years, the EU essentially failed to respond as aspects of democracy were weakened in Hungary. Finally, in September 2018, the European Parliament voted to invoke Article 7 of the Treaty of the European Union. Article 7 makes it possible for the EU to sanction Hungary for violating EU democratic values - possible, but not mandatory. In other words, the European Parliament vote is only a suggestion; for Hungary to actually be suspended from the EU would require a unanimous vote by all other member states, in the context of the European Commission.

Poland and the Czech Republic present similar stories. Like Hungary, Poland joined the EU in 2004 and was initially seen as a successful case of post-communist democratization. However, in 2015, the far-right, populist Law and Justice (PiS) party came to power in Poland. Since then, the Polish government has severely restricted the media and limited the power of the constitutional court. In 2018, Poland faced potential legal action from the EU for jeopardizing rule of law by proposing a series of legislation that would have given the prosecutor general in Poland the power to appoint and dismiss judges throughout the country. More recently still, 
a populist who jokes about murdering opposition journalists, Milos̆ Zeman, was reelected president of the Czech Republic (Ereli, 2018; Ringen, 2018). What role, if any, has the EU played in these surprising instances of backsliding?

This chapter builds on Chapter 4 and provides further evidence in support of the theory proposed in Chapter 3. I argue that the EU's accession process and policy structure unintentionally make democratic backsliding more likely. Although EU scholars have noted that membership conditionality may be problematic (Pridham, 2008; Ugur, 2013), they have not explicitly linked it to the erosion of democratic institutions. I draw on existing research and this project's theoretical framework to trace the ways in which the EU simultaneously increases executive power and also limits institutional development by constraining the domestic policy space. First, EU accession and membership, which are both elite-dominated processes, increase executives' relative power at the domestic level. At the same time, EU conditionality and membership constrain the domestic policy space of states, which stunts the development of institutions of horizontal accountability, such as political parties and legislatures. This combination of factors makes democratic backsliding more likely.

To trace the proposed mechanisms linking IOs, and specifically the EU, to backsliding, this chapter focuses on Hungary and Poland, two states that were subject to extensive EU accession requirements, and, to date, the two most extreme cases of backsliding within the organization. I contrast these cases with two approximations of the counterfactual: Spain and Portugal. These two other third wave democracies joined the EU when accession and membership criteria were much less invasive, and, unlike Hungary and Poland, Spain and Portugal have not experienced backsliding. Finally, I use the synthetic control method (Abadie et al., 2015) to create a synthetic control unit that is comparable to Hungary on dimensions theorized to predict democratic success. This synthetic comparison allows me to estimate what 
Hungary's democratic trajectory would have been had it not joined the EU and thus constitutes another approximation of the counterfactual. In addition to contributing to nascent theories of democratic backsliding as well as to existing research on IOs and regime outcomes, this chapter in particular also builds on work on the limits of EU conditionality, bringing these findings under a common framework and explaining theoretically the mechanisms linking expanded EU membership requirements and democratic backsliding.

\subsection{Applying the Theoretical Framework to the European Union}

IOs have been linked to democratic success in new democracies. Scholars find IOs support these democracies in part by altering elite incentives. IOs increase the costs of anti-democratic behavior via economic sanctions and withholding economic assistance, and they gradually socialize rulers into accepting democracy (Genna and Hiroi, 2014). IOs also influence leaders' international standing, either by helping them build a democratic reputation (Poast and Urpelainen, 2018) or by shaming those who violate electoral norms (Donno, 2013a). Finally, IOs serve as commitment devices, helping democratizing leaders gain the support of domestic elites and deterring opposition elites from overthrowing the new regime (Pevehouse, 2005). In addition, IOs support democracy by promoting elections (Hadenius and Teorell, 2007; Howard and Roessler, 2006; Schedler, 2002). Indeed, electoral assistance is the most common type of democracy assistance from IOs (Johnstone and Snyder, 2016).

Although elections and elite compliance are critical minimal requirements for democracy (Dahl, 1971; Huntington, 1991; Przeworski et al., 2000), they are insufficient to guarantee continued democratic success. The limitations of election monitoring have been identified (Hyde, 2011; Simpser and Donno, 2012), elections are insufficient to promote ongoing democratic progress (Flores and Nooruddin, 2016), and 
even committed autocrats allow elections (Hyde, 2011). Organizations for managing mass participation, representing citizens' interests, and ensuring horizontal accountability, such as political parties, legislatures, and independent judiciaries, are also critical for democracy (Almond and Verba, 1963; Carothers, 2006; Gibler and Randazzo, 2011; Graham et al., 2017; Grzymala-Busse, 2007; Herman, 2015; Huntington, 1968; Mainwaring, 1999; O’Donnell and Schmitter, 1986).

When democracy is defined in reference to elections and elite compliance, the EU has indeed been successful at promoting democracy. The EU is often cited as the IO with the greatest ability to influence regime outcomes, with a particular emphasis on its role in Spain, Portugal, and Greece (Smith, 2001) and post-communist Europe (Dimitrova and Pridham, 2004; Ekiert, 2008; Levitz and Pop-Eleches, 2010; Noutcheva, 2016). Nevertheless, some argue the EU's role in promoting democracy in post-communist countries was limited to pre-accession institution building; following accession, the EU lost the leverage needed to continue to influence domestic politics (Grabbe, 2014; Pridham, 2008; Rupnik, 2007; Ugur, 2013). In the following sections, I take these findings further, arguing that the EU's extensive accession process and policy structure unintentionally both impede institutional development and increase executive power. This combination of factors makes backsliding more likely.

\subsubsection{The EU and Executive Power}

The first way in which the EU unintentionally contributes to backsliding in its

member states is linked to the fact that the EU creates power asymmetries between the executive and other branches of government by increasing relative executive power. During the accession process, which favors executives over other government bodies (Grabbe, 2001; Follesdal and Hix, 2006), institutions are created from above 
without support from political groups or civil society (Bugaric, 2015). Instead, Euroexperts and other bureaucrats charged with preparing a state for accession are housed within the executive branch, thereby giving executives access to additional information and the power to influence domestic institutional formation. The 2004 and 2007 accessions in particular were elite-led, dominated by foreign policy officials, and devoid of public debate (Grabbe, 2014; Pridham, 2007).

The EU's strategies for democracy promotion further increase executive power. Democracy promotion is often not undertaken with the sole purpose of building democracy but is also driven by a desire to promote economic and regional stability. Reflecting these considerations that go beyond democracy, in post-communist Europe more attention went to economic transformation and stability - which involves the construction of regulatory, economic, and other bureaucratic offices - than to support for democratic institutions (Smith, 2001).

For example, focusing on the EU's role in Estonia, Raik notes that the logic underlying this process "promoted bureaucratic, executive-dominated policy making and left little room for democratic politics" (Raik, 2004, 591). This bureaucratic approach is an artifact of the technocratic nature of the organization itself and is linked the EU's conditions for membership. Bureaucracies are created during the preaccession phase to facilitate the implementation of the EU's extensive membership requirements, as outlined in the acquis communautaire, and also to ensure states will comply with EU policies after accession.

The disproportionate attention devoted to bureaucratic institutions has negative consequences for democracy. A strong bureaucracy, which signals high levels of state capacity, is not inherently detrimental to democracy and is even linked to democratic 
success (Fortin, 2012; Grzymala-Busse, 2007). However, the EU invests predominantly in the bureaucracy at the expense of more democratic institutions. The result is a state with a strong executive that controls a powerful bureaucracy.

Membership in a highly integrated EU further increases executive power. Domestic executives serve as intermediaries between their state and EU institutions. Indeed, EU scholars have identified the EU's democratic deficit, characterized in part by the fact that European integration and membership result in increased power for national executives at the supranational level, with a coinciding decrease in parliamentary control (Follesdal and Hix, 2006). For example, executives represent their countries in the European Council, the EU's most powerful political body (Tallberg, 2008). In addition, increased integration has further limited domestic legislatures' control over a range of policy decisions, such as commercial negotiations, which have been monopolized by the EU Commissioner for Trade (Nanou and Dorussen, 2013).

On their own, strong executives are not necessarily bad for democracy. However, when these powerful executives are surrounded by institutions that are too weak and too underdeveloped to act as a check on their power, democratic backsliding becomes more likely. This leads to the second mechanism linking the EU to democratic backsliding in its member states: the EU limits countries' domestic policy space, which stunts the development of important democratic institutions in new democracies, including those that check executive power.

\subsubsection{The EU and the Domestic Policy Space}

EU membership conditionality expanded significantly with the Maastricht Treaty in 1992, the Copenhagen Criteria in 1993, and the EU's use of active leverage over candidate states beginning in 1997. EU conditionality requires candidate and member states to adopt extensive, non-negotiable institutions, laws, and policies; these policy 
requirements continue into the membership phase. As a primarily economic organization with a single market, common currency, and shared budget, these requirements result in neoliberal economic and fiscal policy convergence across the EU (Cao, 2009; Grabbe, 2014). For example, the EU's direct influence over monetary policies, resulting from the founding of the European Monetary Union, gives it tremendous influence over national policies regarding budgetary policies, which are "restricted or even codetermined by the European Commission as the Stability and Growth Pact limits a country's budget deficit to 3\%" (Katsanidou and Otjes, 2015). Policy constraints resulting from increased European integration limit candidate and member states' domestic policy space, or the range of available policies they can adopt. This impedes party system institutionalization, especially in new democracies, by hindering parties' abilities to debate policy alternatives (Grzymalaa-Busse and Innes, 2003; Vachudova, 2008) and leaves the legislature underdeveloped by limiting its policy-making role.

Institutionalized parties compete in elections by situating themselves along salient, politicized societal cleavages linked to policy outcomes (Lipset and Rokkan, 1967). However, EU requirements leave fewer policy alternatives, and voters know economic options are limited (Hellwig, 2014). Therefore, it is difficult for parties to differentiate themselves based on economic appeals. Instead, they emphasize non-economic valence issues, or uncontroversial issues "on which all parties declare the same objective but dispute each other's competence in achieving the desired policy" (Kitschelt et al., 1999, 137), such as corruption or nationalism. This is true for both niche and mainstream parties (Ward et al., 2015). As a result, domestic party competition has been hollowed out as EU integration has progressed, and the ideological distance between mainstream parties has decreased (Mair, 2007). This is particularly problematic for new democracies and impedes their continued democratic progress, which depends in part on the extent to which parties structure political conflict (Dix, 1992; 
Mainwaring, 1998). Furthermore, parties serve as an important check on executive power and thus as a critical institutional safeguard against democratic backsliding.

EU policy requirements also have negative implications for the development and institutionalization of legislatures in new democracies. In addition to stunting party system development, the policy requirements detailed in the acquis communautaire infringe on one of the primary roles of legislatures: proposing, drafting, and implementing legislation. This marginalization of the legislature has several consequences. First, legislatures create an impetus for party system development; however, when legislatures are weak, parties lack a forum in which to develop and mature. Another consequence is that the legislature, which plays a critical role in providing horizontal accountability, is unable to check executive power. Indeed, in addition to the judiciary and opposition parties, legislatures are the primary institutional check on executive power (Diamond et al., 1999; Fish, 2006; O'Donnell, 1999).

Finally, a diminished domestic policy space alters policy debates and limits the extent to which politicians can compete for office based on ideological differences. Unable to credibly propose future changes to policies imposed by the EU, incumbents and political parties instead rely on valence issues and populism to appeal to voters. Populism is characterized by nativist, authoritarian ideologies. Indeed, many populist parties define themselves in direct opposition to key features of liberal democracy, such as political safeguards, constitutional protection of minority rights, individualism, and the intermediary institutions of liberal democracy (Minkenberg, 2002; Mudde, 2007; Bugaric, 2008; Linden, 2008). ${ }^{28}$

\footnotetext{
${ }^{28}$ Since populism tends to be inherently opposed to liberal democracy, the goals of populists often involve the altering or dismantling of liberal democratic institutions; in other words, they advocate processes characteristic of democratic backsliding. As such, populism is a common characteristic of states experiencing democratic backsliding, but the presence of populist parties alone is insufficient to categorize a case as one of backsliding.
} 
In short, heightened executive power without a proportional increase in the strength of other domestic institutions that check executive power - such as opposition parties and national legislatures - is a relevant factor with respect to democratic backsliding, which often involves unchecked executive powers. Indeed, critics argue the EU exported its democratic deficit to Central and Eastern Europe, producing shallow democracies, and studies have shown that the democratic deficit "has a more visible impact on late accession countries (which are required to adopt a much larger body of European laws and regulations) and on countries with less robust democratic traditions" (Ekiert, 2008, 19). I build on existing research to argue that by simultaneously increasing executive power and stunting institutional development by limiting domestic policy options, the EU creates conditions conducive to backsliding in its member states. This is especially so for new democracies, where institutional checks on the executive, such as party systems, legislatures, and judiciaries, have not had sufficient time or opportunity to develop.

\subsection{Research Design}

Illiberalism and democratic backsliding have been on the rise throughout postcommunist Europe (Rupnik, 2016). Of the 10 post-communist countries that joined the EU in 2004 and $2007,{ }^{29}$ only Estonia and Latvia have improved their levels of democracy since accession (Schenkkan, 2017), whereas the remaining seven have declined to varying degrees. These trends are perhaps unsurprising in Bulgaria and Romania, which consistently lagged behind with respect to democratization (Spendzharova and Vachudova, 2012). However, backsliding has even occurred in the Visegrad

\footnotetext{
${ }^{29}$ Bulgaria, the Czech Republic, Estonia, Hungary, Latvia, Lithuania, Poland, Romania, Slovakia, and Slovenia.
} 
countries ${ }^{30}$ which were undisputed leaders during the democratization process. Figures 5.1, 5.2, and 5.3 illustrate the illiberal trends in this region, tracing the Democratic Institutional Strength (DIS) index over time for each of the eight countries that joined the EU in 2004.

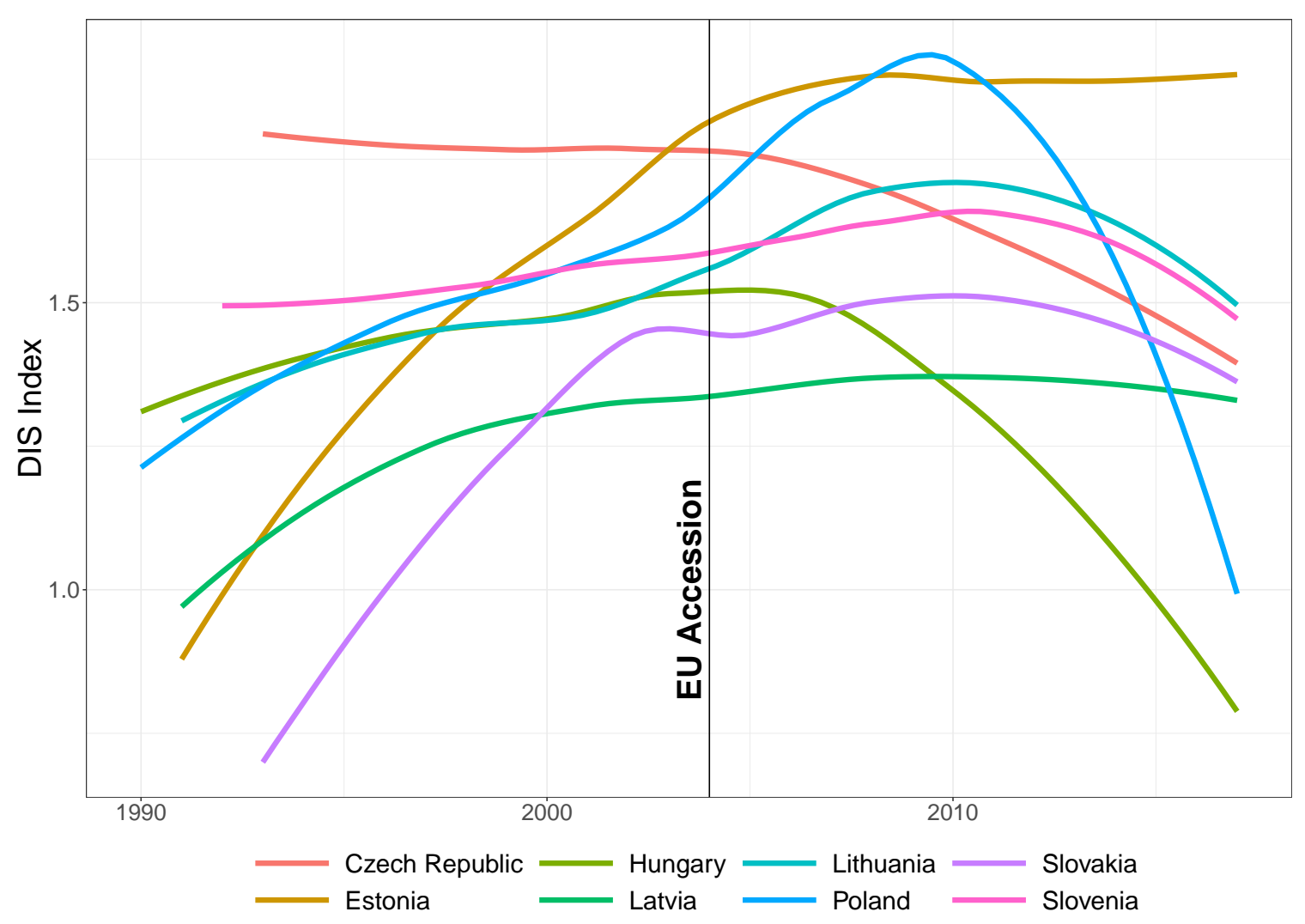

Figure 5.1: Democracy levels over time in all 2004 EU accession states.

I focus on the two most extreme cases of backsliding in the EU: Hungary and Poland. It is particularly puzzling that Hungary and Poland have undergone backsliding since they received extensive democratization aid from the EU, were initially viewed as the two most successful cases of post-communist democratization (Varga

\footnotetext{
${ }^{30}$ Hungary, Poland, the Czech Republic, Slovakia, and Slovenia.
} 


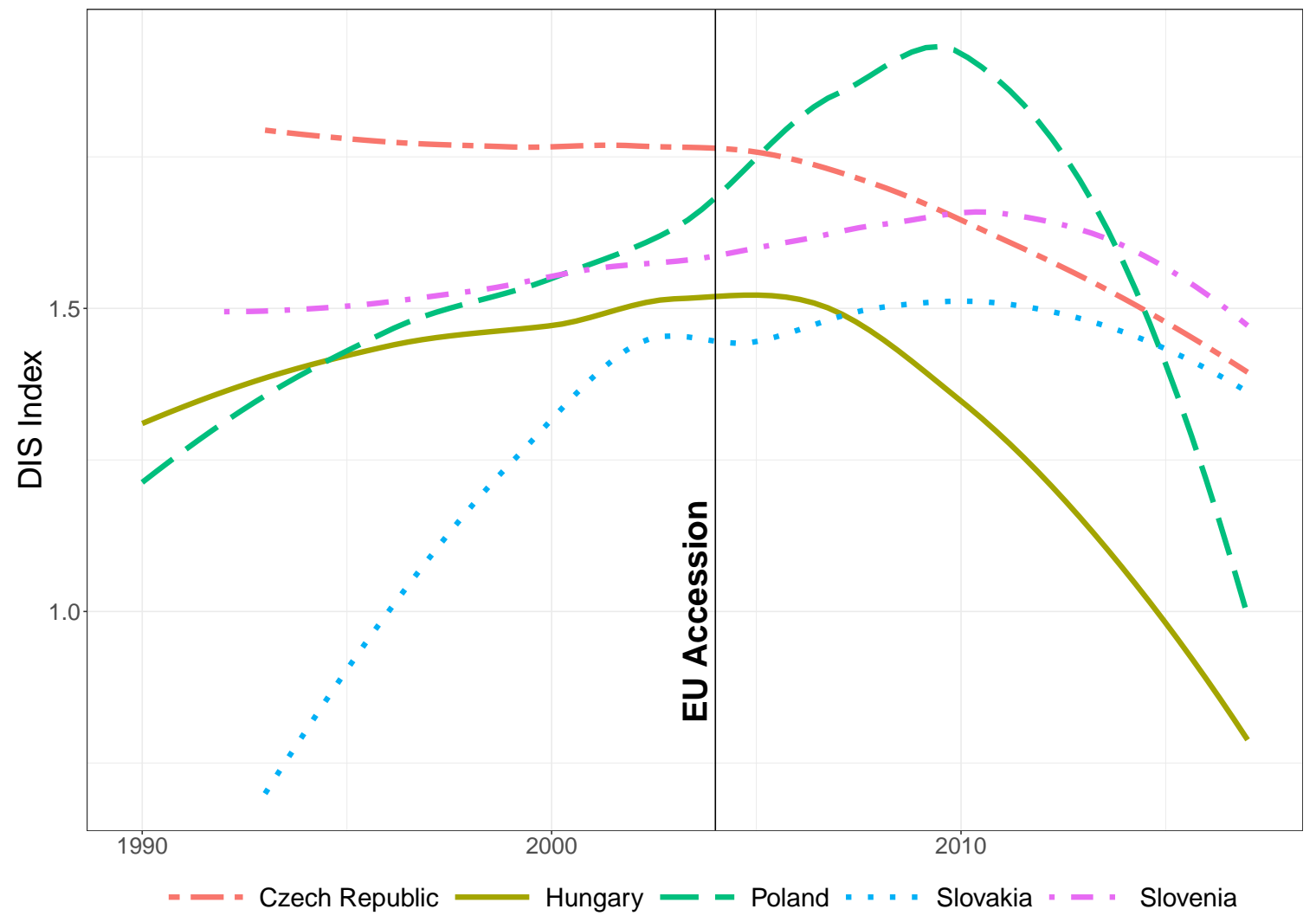

Figure 5.2: Democracy levels in the Visegrad region have declined since these countries joined the $\mathrm{EU}$ in 2004. 


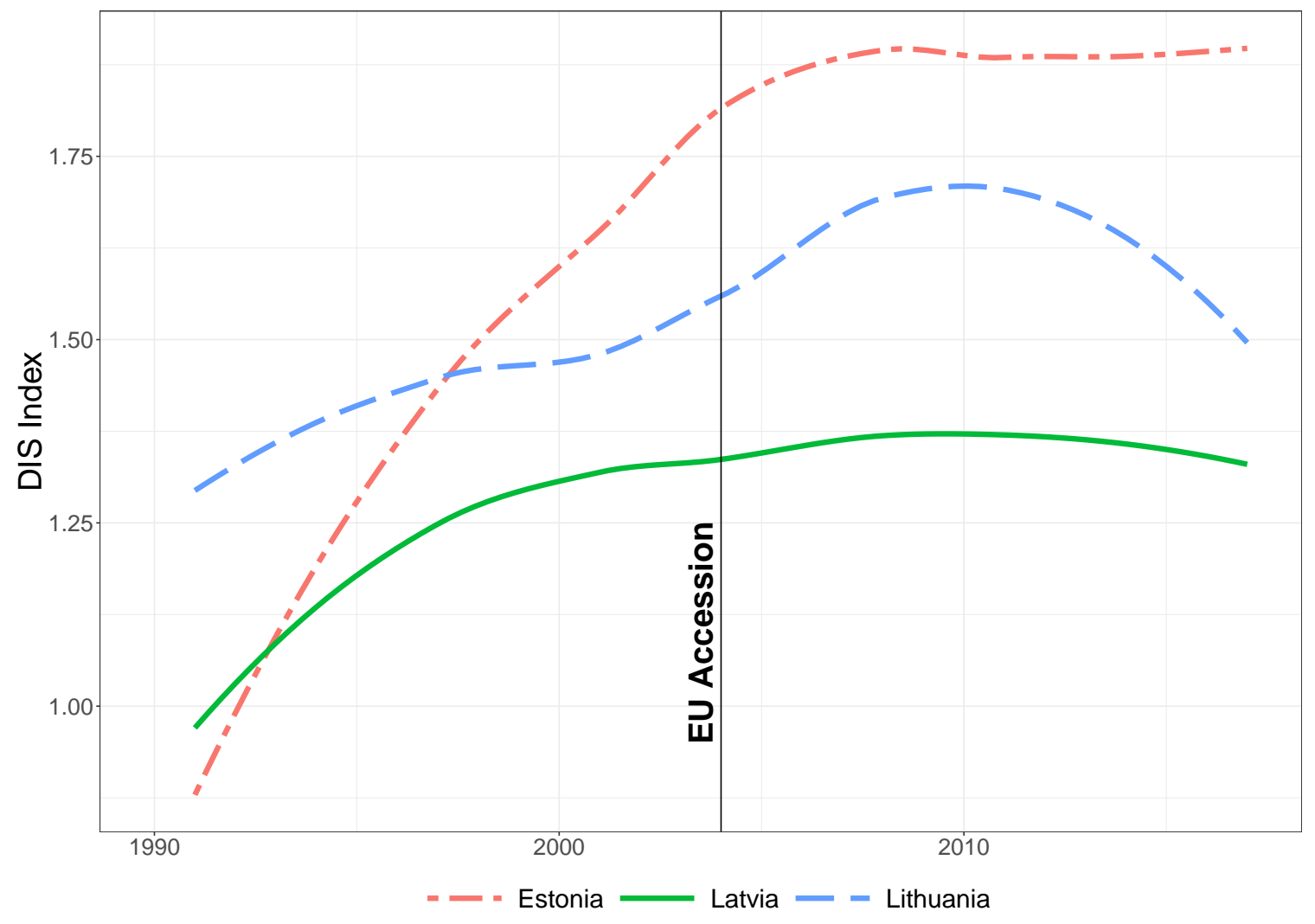

Figure 5.3: With the exception of Estonia, democracy levels in the Baltics have declined or stagnated since these countries joined the EU in 2004. 
and Freyberg-Inan, 2012), have relatively high levels of economic development (Lipset, 1959), and have low levels of inequality (Boix, 2003). These countries received similar amounts of aid and influence from the EU and were subject to the same accession and membership requirements (Vachudova, 2005).

This chapter uses a multi-method approach to link the EU's extensive accession and membership criteria, which became particularly onerous beginning with the eastern enlargement of the EU, to democratic backsliding in new democracies. I do this, first, by considering how the EU's requirements, and thus its effect on new democracies, have changed over time. As shown in Figure 5.1, backsliding and rising illiberalism have emerged throughout post-communist Europe, all of which was subject to similar accession processes and high levels of conditionality. In other words, there is limited variation on the independent and dependent variables in this region. However, the EU accession process has not always been so extensive; rather, it became so with the signing of the Maastricht Treaty in 1992, the introduction of the Copenhagen Criteria in 1993, and the EU's use of active leverage over candidate states, which began in 1997. Therefore, studying the impact of low EU conditionality and less intrusive accession processes on new democracies requires going back in time.

Each time the EU admits additional members, the optimal level of integration for existing members increases; this happened following the accession of Spain, Portugal, and Greece in the 1980s. One result of the higher levels of integration that followed was the creation of a significantly longer list of requirements that subsequent entrants were required to accept (Pahre, 1995). Drawing on the fact that EU accession and policy requirements have become more extensive over time, I contrast Hungary and Poland, the two most extreme cases of backsliding in the EU to date, with two canonical third wave democracies that joined the EU prior to increased integration: Spain and Portugal. As Figure 5.4 illustrates, unlike Hungary and Poland, Spain's 
and Portugal's levels of democracy continued to improve and then remained stable for between 15 and 20 years after joining the EU.

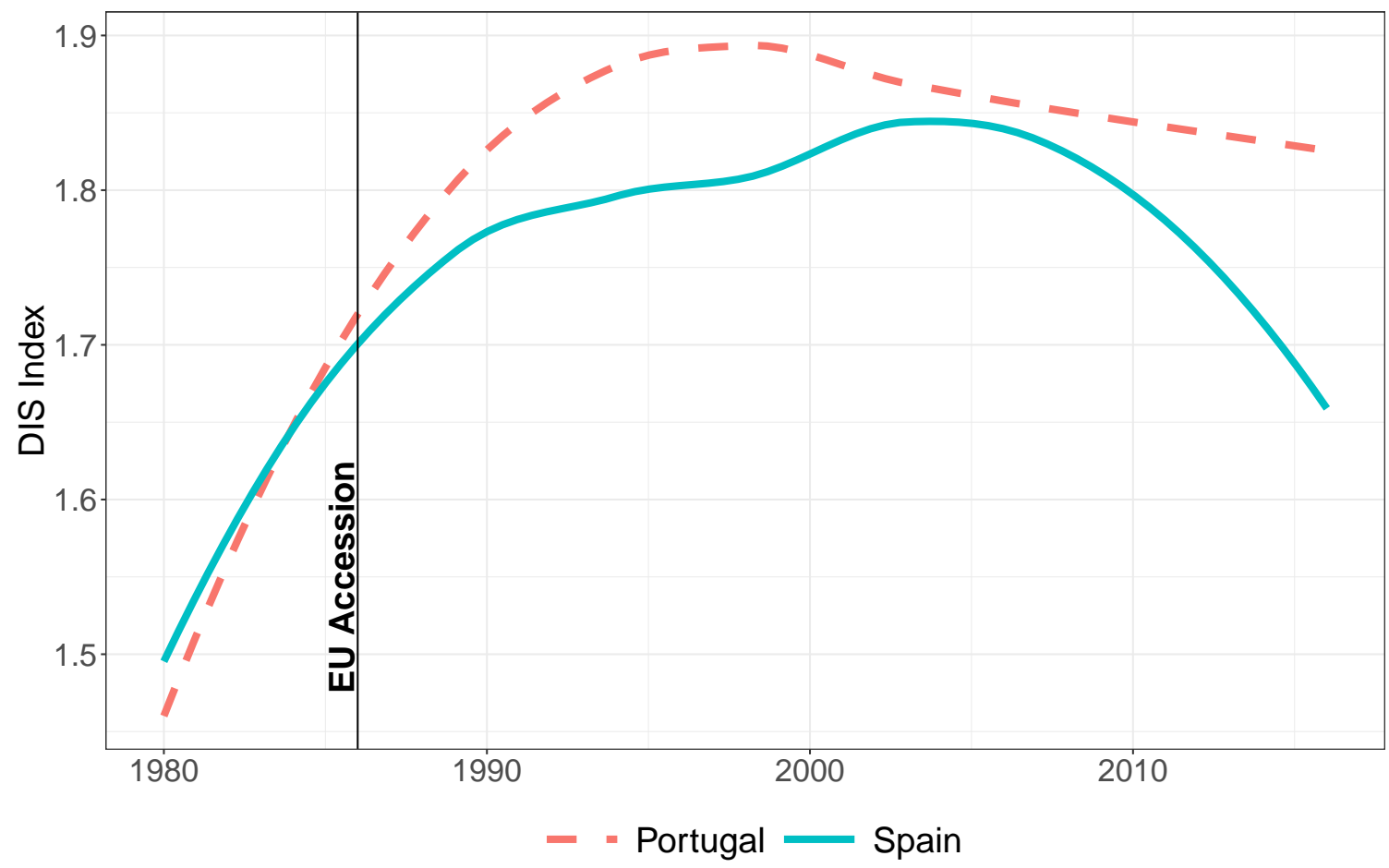

Figure 5.4: Unlike Hungary and Poland, for the first two decades after joining the EU, Spain's and Portugal's levels of democracy steadily rose.

In contrast to Hungary and Poland, membership conditionality for Spain and Portugal was much less extensive, occurred on much more of an ad hoc basis, and required the adoption of significantly fewer domestic policies than was the case for Hungary and Poland. I argue that these differences in the accession processes, all of which occurred shortly after these four states' transitions to democracy, in part account for the relative success of democracy in Spain and Portugal when compared to Hungary and Poland. Of course, Hungary and Poland are not directly comparable to Spain and Portugal: there are important differences due to the legacies of communism 
as well as the differences in the international system at their times of democratization. Nevertheless, all of these states were third wave democracies that experienced different degrees of international influence when transitioning to democracy; therefore, the comparison provides insight into the effects of varying levels of EU accession criteria.

Since there are these important differences between Hungary and Poland on one hand and Spain and Portugal on the other, after outlining Spain and Portugal as comparison cases, the following section uses a synthetic case study to estimate the impact of EU accession on Hungary's democratic trajectory. In the synthetic control method, a comparison unit is constructed using "the weighted average of all potential comparison units that best resembles the characteristics of the case of interest" (Abadie et al., 2015, 496). This allows me to construct a case that is similar to pre-accession Hungary along dimensions that predict democratic success and then to observe the synthetic case's democratic trajectory absent treatment (EU accession). I find evidence that joining the EU negatively impacted Hungary's subsequent democratic trajectory.

Finally, having established the plausibility of the EU contributing to backsliding in new democracies in the post-Maastricht era, the remainder of the chapter traces the proposed mechanisms linking the EU to backsliding, focusing specifically on Hungary and Poland.

\subsection{The Accession Process in Spain and Portugal}

Spain and Portugal were among the first third wave democracies to join the EU. Spain and Portugal joined the EU in 1986, prior to the signing of the Maastricht Treaty in 1992, which significantly increased levels of integration among EU member states. When Spain and Portugal became members, the EU was a primarily economic organization with a common market and customs union. The original common 
market was a free trade area that eliminated quotas and tariffs and provided for the free movement of capital, services, and workers yet maintained non-tariff barriers to trade. The Maastricht single market that Hungary and Poland joined, on the other hand, eliminated all existing trade barriers by imposing EU-wide regulations designed to create a level playing field. This required the harmonization of national rules governing products and goods at the EU level (Dinan, 2005).

Spain and Portugal also spent a longer time at the Association Agreement stage of negotiations with the EU than Hungary and Poland. During this stage, the EU negotiated bilateral free trade agreements with both Spain and Portugal and gave them extended time tables for dismantling tariffs to comply with common market requirements (Preston, 1995). In contrast, formal negotiations for membership did not begin for Hungary and Poland until 1997, giving these states far less time to undertake significantly more extensive policy reforms prior to their 2004 accessions. This, combined with the single market, severely limited Hungary's and Poland's domestic policy spaces and stunted democratic institutional development.

Furthermore, when Spain and Portugal were candidates, political and especially democratic membership criteria were largely ad hoc. This was the first time the EU needed to consider political conditions for membership. In response to their initial applications for membership, the EU issued the 1962 Birkelbach report, which stated that only liberal democracies would be admitted (Whitehead, 1991; Powell, 1996; Magone, 2004). This served as a critical incentive for Spain and Portugal to democratize; however, the EU's actual involvement in their democratic transitions was largely symbolic and passive. In contrast, the EU had extensive political conditions for membership for Hungary and Poland, as outlined in the 1993 Copenhagen Criteria, and it began actively monitoring and evaluating compliance with these conditions in 1997 (Vachudova, 2005). 
Although domestic actors were heavily influenced by external rules, structures, and incentives, the less extensive accession criteria made it so that democratization in Spain and Portugal was more bottom-up and domestically driven than in postcommunist Europe. These countries spent over a decade building democracy before joining the EU, and they acceded prior to Maastricht, which greatly increased levels of integration, and thus policy linkages, between EU member states. As a result, their domestic policy spaces remained relatively independent of international influence during their early years as democracies, allowing political parties and other representative institutions to develop. This is in sharp contrast to Hungary and Poland, two states that were seeking to join a "substantially more integrated [EU] following the completion of the Single European Market and the Maastricht commitments ... from a lower economic base" (Preston, 1995, 459).

However, as Figure 5.4 illustrates, around 2005, Spain and Portugal also began to show signs of backsliding. Nevertheless, the fact that this occurred two decades after these countries joined the EU rather than immediately following accession, as was the case for the 2004 accession states, is consistent with my argument. These trends suggest that backsliding in Spain and Portugal is attributable to the EU in the same way that I argue is the case for the 2004 accession countries. As noted above, at the time of the 1986 Mediterranean expansion, the EU (then the European Community) was much less politically and economically integrated, required the adoption of far fewer domestic policies, and accorded less power to state-level executives. Therefore, the more recent backsliding may be linked to increased integration that resulted from the creation of the EU. 


\subsection{Synthetic Case Study: The Impact of EU Accession on Democracy in Hungary}

Although the comparison with Spain and Portugal provides some important insights regarding the implications that a pre- versus post-Maastricht EU has for democratic trajectories among its newly democratic member states, this comparison, and traditional comparative case studies more broadly, has several shortcomings in this study. First, although Spain and Portugal were subject to quite different treatments than those received by Hungary and Poland, the fact remains that all four of these countries were treated to some extent. An ideal experimental framework would include cases that received treatment (EU accession) and ones that are similar on all dimensions except that they did not receive treatment. Unfortunately, in Europe, this scenario does not exist: all relatively successful democracies in Europe are members of the EU. In addition to this limitation in selecting control cases within the European context specifically, the comparative case method more broadly lacks a systematic way to test the credibility of a selected control unit and is often somewhat arbitrary since the controls are chosen by the analyst. Another problem is that cases of interest in comparative politics are often highly aggregated units - such as countries - that do not have a single suitable comparison case (Gerring, 2007; Lijphart, 1971). Given these constraints, one danger of comparative case studies is that if the comparison units are not sufficiently similar to the unit of interest along dimensions other than treatment, then any observed differences in outcomes may simply be due to differences in the units more generally and not a result of the intervention specifically (Geddes, 1990; King et al., 1994).

Although it can identify correlations and trends in the data, large- $n$ analysis is also limited in the case of the EU. Regression analysis weights potential control units in the dataset to approximate the counterfactual for a given unit of interest, though 
these weights are not usually explicitly discussed or shown (Abadie et al., 2015). However, because these weights are unrestricted, and can be negative or greater than one, the model extrapolates outside the support of the available data if no similar control cases are available. In other words, even if no good approximation of the counterfactual exists, the regression weights will produce a fit.

The synthetic control method tries to address these shortcomings of traditional comparative case studies and of large- $n$ analysis. Conceptually, it builds on Mill's method of difference (Mahoney, 2000), which compares the treated unit to units that are similar on relevant dimensions except for whether or not they receive treatment; then, the differences in outcomes between the treated and control cases is the approximation of the treatment effect of the intervention. Specifically, the synthetic control method is a data-driven approach to the control unit selection method. It aggregates comparison units from a set of potential controls, called the "donor" units, each weighted by its similarities to the case of interest based on longitudinal quantitative data to create a synthetic counterfactual case. In this way, unlike the classic comparative method, the synthetic case control method is a systematic way of choosing the comparison unit. The synthetic control estimator is a generalization of the difference-in-differences (fixed effects) models commonly used in cross-national regression analysis, but it is bounded between 0 and 1 to avoid the data extrapolation that can occur in large- $n$ regression analysis (Abadie et al., 2011, 2015; Abadie and Gardeazabal, 2003).

In this section, I use the synthetic control method to estimate the impact of Hungary's accession to the EU on Hungary's democratic trajectory. Hungary was one of the first developing democracies to join the EU following the signing of the Maastricht Treaty and, to date, is the most extreme case of backsliding among EU member states. By creating a synthetic control case that is similar to Hungary along 
all characteristics related to democracy but one-treatment, or joining the EU-I estimate the effect of EU accession on Hungary's democratic trajectory. Because all successful democracies in Europe are members of the EU, I draw on a set of donor countries from new democracies in comparable regions to construct the synthetic comparison case for Hungary.

\subsubsection{Method, Data, and Sample}

To create a synthetic control unit, I use country-level panel data for the period 1991-2015. Since Hungary joined the EU in 2004, this provides for a 13-year pre-intervention period. ${ }^{31}$ To construct the synthetic Hungary, which is a weighted average of potential control countries, I identify a pool of donor countries that meets several criteria. First, donor countries must not include states that were impacted by the treatment (EU accession). In addition, donor countries should have characteristics similar to the treated unit that are relevant to the outcome of interest: democracy (Abadie et al., 2015). Using these criteria, I construct a donor pool that includes a sample of 20 third wave democracies ${ }^{32}$ in Europe and Latin America that are not members of the EU: Albania, Argentina, Bolivia, Brazil, Chile, Dominican Republic, Ecuador, El Salvador, Guatemala, Haiti, Honduras, Mexico, Moldova, Nicaragua, Panama, Paraguay, Peru, Russia, Ukraine, and Uruguay. I focus on third wave democracies in Europe and Latin America since new democracies in these two regions have had the most similar experiences with democracy.

The outcome variable is my original indicator of democratic backsliding, the DIS index introduced in Chapter 2. For the pre-accession characteristics, I identify a set

\footnotetext{
${ }^{31}$ I begin in 1991 so that the focus is exclusively on the post-Cold War period when Hungary was a democracy.

${ }^{32}$ I define a third wave democracy as any state that transitioned to democracy after 1974 (Huntington, 1991).
} 
of variables predicted to impact a state's success with democracy to construct the synthetic Hungary: GDP per capita (Feenstra et al., 2015; Lipset, 1959), state age (Correlates of War Project, 2016), civil conflict (Allansson et al., 2017; Gleditsch et al., 2002; Hegre, 2014), oil income per capita (Ross, 2015; Ross and Mahdavi, 2015), ethnic fractionalization (Alesina et al., 2003; Nardulli et al., 2012), and party system institutionalization (Coppedge et al., 2018; Mainwaring and Scully, 1995).

Using these data and the Synth package in R (Abadie et al., 2011), I construct a synthetic Hungary. The Synth package weights observations from countries in the donor pool by choosing weights that minimize the mean squared prediction error of the outcome variable in the pre-intervention period (1991-2003). The resulting synthetic case for Hungary is the weighted average of Uruguay (0.74) and Ukraine (0.26); all other countries in the donor pool have zero weights. Table 5.1 compares the pre-accession characteristics of Hungary to those of the synthetic case and also to those of a population-weighted average of all third wave countries included in the donor pool. For all characteristics, the synthetic case is a better comparison for Hungary.

Table 5.1: Democracy Predictor Means before EU Accession

\begin{tabular}{lrrr}
\hline \hline & Hungary & Synthetic Hungary & Third Wave Sample \\
\hline GDP per capita & 14720.06 & 9695.66 & 6177.47 \\
State age & 79.00 & 86.62 & 117.02 \\
Civil conflict & 0.00 & 0.00 & 0.11 \\
Oil income per capita & 31.008 & 5.35 & 86.56 \\
Ethnic fractionalization & 0.13 & 0.25 & 0.41 \\
Party institutionalization & 0.86 & 0.81 & 0.60 \\
\hline \hline
\end{tabular}




\subsubsection{The Impact of EU Accession in Hungary}

Figure 5.5 shows the democratic trajectory of Hungary and synthetic Hungary for 1991-2014. Prior to Hungary's accession to the EU, Hungary and the synthetic case are a close fit; however, they diverge once Hungary joins the EU in 2004. My estimate of the effect of EU accession on democracy in Hungary is the difference between the actual Hungary and its synthetic comparison, as illustrated in Figure 5.6.

Although the synthetic case's level of democracy also begins to decline around 2010, it nevertheless maintains overall higher levels of democracy than Hungary throughout the post-treatment period. This is likely due to the fact that democratic backsliding cannot be linked to one unique cause: EU accession. Rather, it is a result of a combination of factors, both at the international and domestic levels. Nevertheless, the differences that emerge between Hungary and synthetic Hungary following 2004 suggest that the EU did influence Hungary's democratic trajectory.

To test if these findings are credible, I conduct two placebo tests. First, I compare the estimated effect of EU accession on Hungary's democratic trajectory to a placebo effect calculated by reassigning the treatment to a year before Hungary joined the EU (Abadie et al., 2015). If there is a large effect on Hungary's level of democracy resulting from the placebo accession, this would suggest the results from Figure 5.5 are simply due to lack of predictive power of the model.

I re-estimate the same model, this time assigning Hungary's treatment to 1998. As Figure 5.7 shows, the democratic trajectories of Hungary and synthetic Hungary do not diverge considerably during the 1991-2004 period, and the placebo accession does not lead to a large difference between the two cases; this provides initial support that the effect in Figure 5.5 is in fact attributable to EU accession.

Next, I apply the synthetic control method to Uruguay, the control case that was most similar to Hungary in the pre-treatment period (Abadie et al., 2011). If 
Trends in Democracy, Hungary vs. Synthetic Hungary

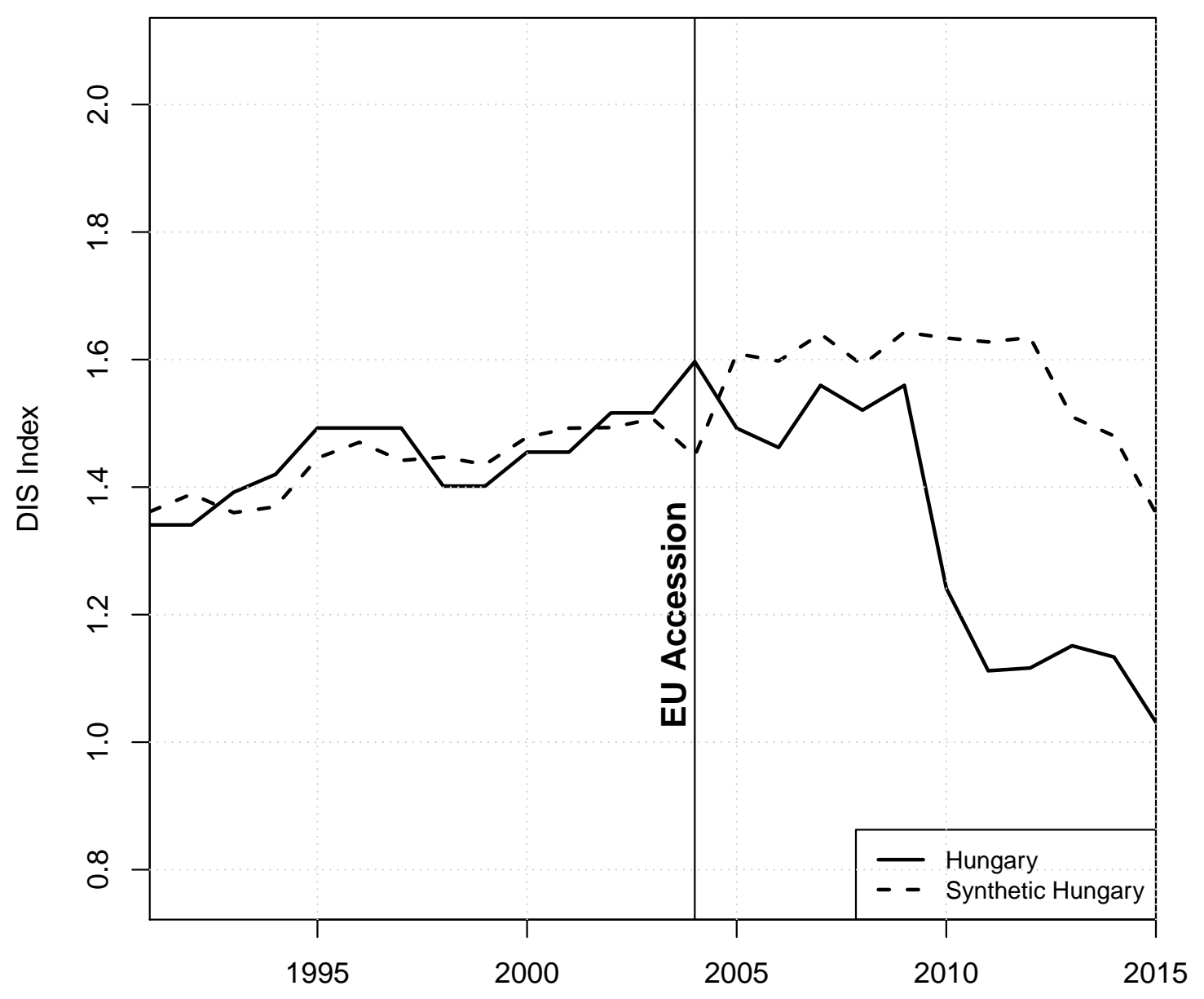

Figure 5.5: Hungary and the synthetic case have nearly identical democratic trajectories in the pre-accession period. Following Hungary's accession to the EU in 2004, Hungary's level of democracy diverges. 


\section{Democracy Gap between Hungary and Synthetic Hungary}

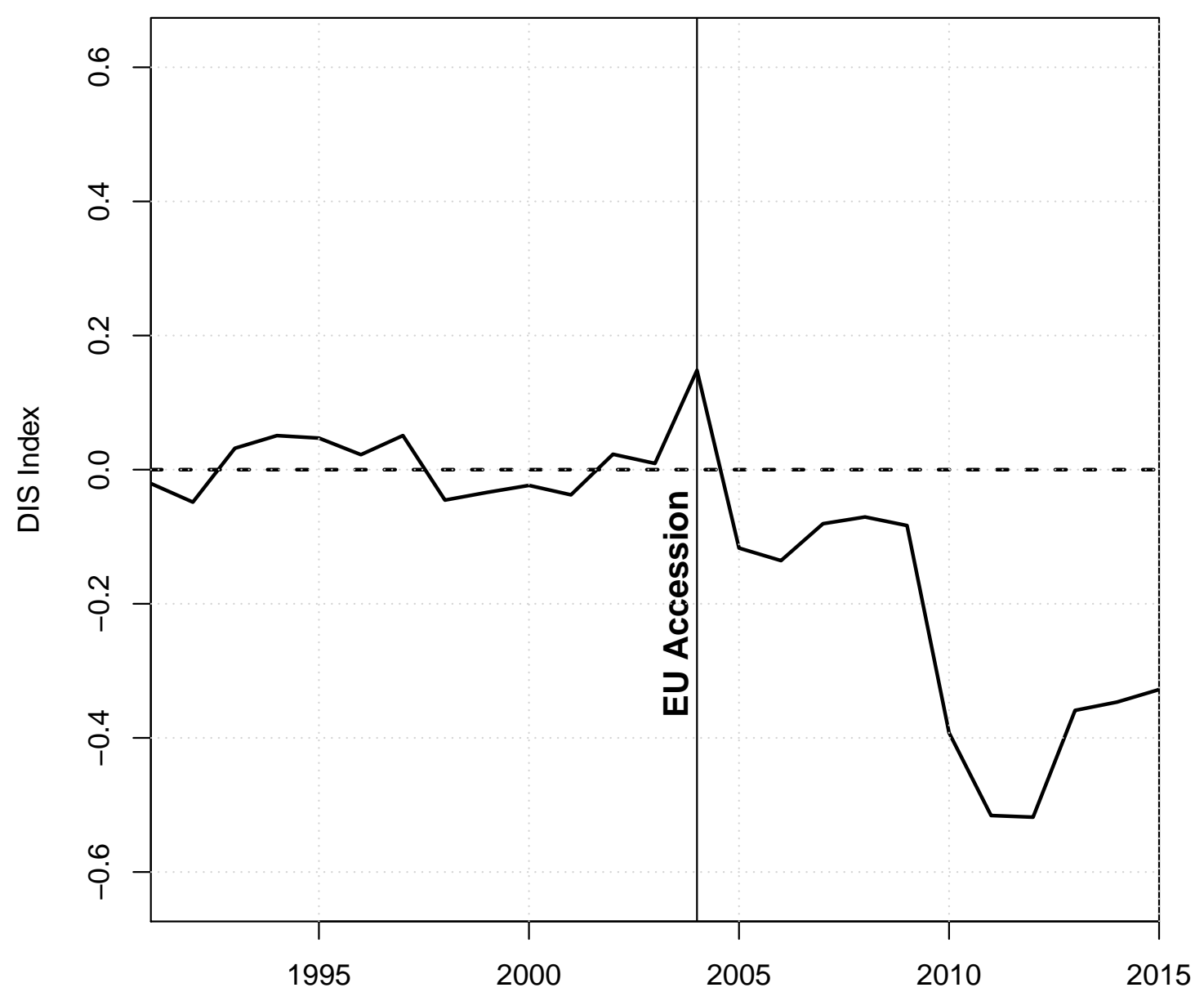

Figure 5.6: Hungary's and synthetic Hungary have similar liberal democracy scores prior to 2004; however, after joining the EU, Hungary's democracy score drops when compared to synthetic Hungary's. 


\section{Placebo 1998 EU Accession: \\ Trends in Democracy, Hungary vs. Synthetic Hungary}

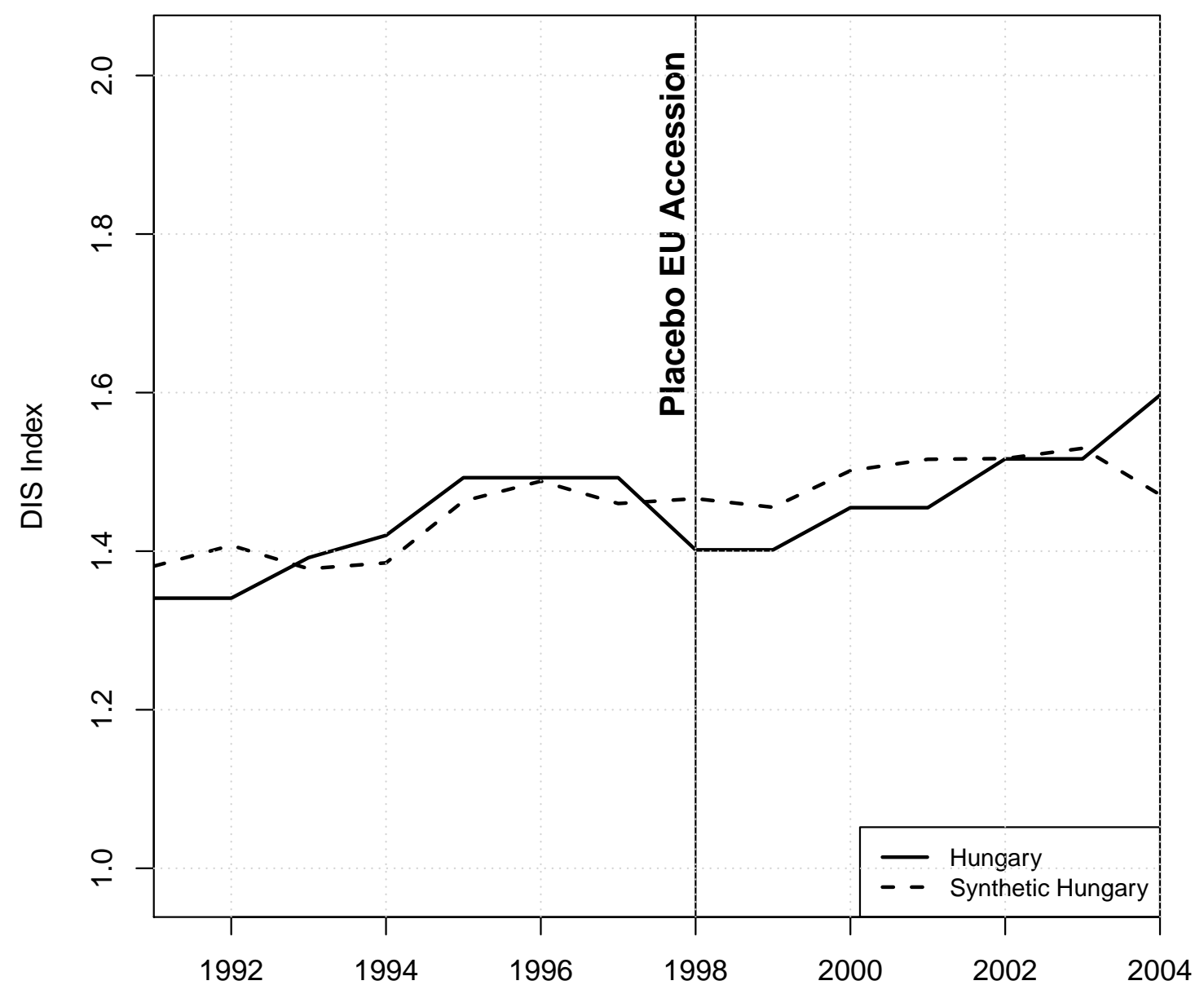

Figure 5.7: Hungary and synthetic Hungary's levels of democracy do not diverge substantially following the placebo treatment. This suggests that the results from Figure 5.5 are not merely driven by poor predictive power of the synthetic control. 
EU accession meaningfully impacted Hungary's democratic trajectory, I should find no comparable treatment effect when Uruguay is treated. Comparing Figure 5.5 to Figure 5.8 shows that the treatment effect of EU accession for Hungary is relatively large when compared to its effect on Uruguay. This further suggests EU accession had a meaningful impact on democracy in Hungary.

To summarize, using the synthetic control method I find evidence that joining the EU in the post-Maastricht era affected Hungary's democratic trajectory. In the remainder of the paper, I use process tracing, focusing on Hungary and Poland, to illustrate the mechanisms linking the EU to democratic backsliding in new democracies: increased executive power and a diminished policy space, which stunts institutional development.

\subsection{Tracing Democratic Backsliding in Hungary and Poland}

In 1990, Hungary and Poland identified joining the EU as a primary foreign policy objective (Vachudova, 2005). Hungary was the first post-communist country to redirect its trade to the West, import western institutions and policies, and establish official contacts with the EU. Both countries signed Europe Agreements in December 1991 (Ágh, 1999), and at the 1993 Copenhagen Summit the EU indicated promises of future eastern enlargement. The Copenhagen Criteria consist of political and economic conditions for EU membership, including "stability of institutions guaranteeing democracy, the rule of law, human rights, and respect for protection of minorities" (Rose-Ackerman, 2005, 43). Another condition for membership is adoption of the acquis communautaire. The acquis is an 80,000-page non-negotiable document outlining the laws, norms, and regulations in force in EU member states. In 1994, the EU Agreements went into force, and shortly thereafter Hungary and Poland became the first two post-communist states to apply for EU membership (Vachudova, 


\section{Placebo Test:}

Trends in Democracy, Uruguay vs. Synthetic Uruguay

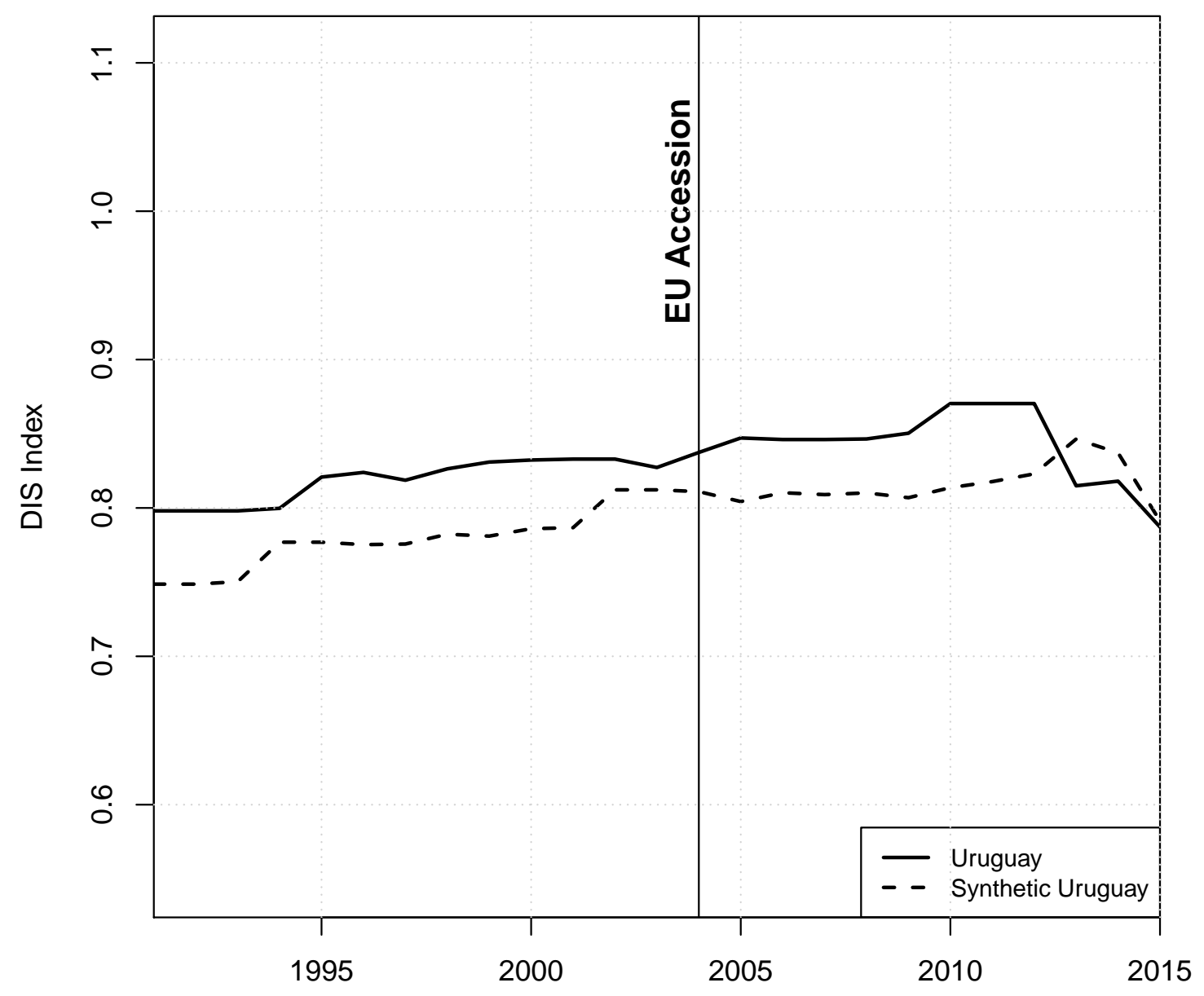

Figure 5.8: There is no identifiable treatment effect of EU accession on Uruguay, the control case that was most similar to Hungary in the pre-treatment period. This provides further support for the finding that joining the EU impacted Hungary's democratic trajectory. 
2005). Throughout the 1990s and early 2000s, Hungary and Poland were leaders in pre-accession talks with the EU (Herman, 2015).

Nevertheless, Hungary and Poland represent the most severe cases of backsliding within the EU. Under Orbán and Fidesz, the Hungarian government has become increasingly illiberal. After gaining a two-thirds majority in the 2010 elections, Fidesz limited the jurisdiction of the constitutional court, curtailed electionmonitoring mechanisms, eliminated checks on presidential power, and enacted a new constitution to consolidate the party's power (Bánkuti et al., 2012; Muller, 2013).

Similarly, in Poland in 2015, the Law and Justice party (PiS) - another right-wing populist party, led by Jarosław Kaczyński - won the presidency and secured a parliamentary majority. Since then, the Polish government has aggressively embraced majoritarianism and attempted to eliminate government checks and balances by attacking the high court, the prosecutor's office, the media, and the civil service (Fomina and Kucharczyk, 2016). Continued attempts by the ruling party to delegitimize the judiciary have raised concerns about the future of rule of law in Poland (Nalepa, 2017) and of democracy more generally (Kelemen and Orenstein, 2016).

Researchers have explained these cases of backsliding by focusing on domesticlevel factors such as economic recession and stagnation (Hernandez and Kriesi, 2016), corruption (Hanley and Sikk, 2016), the migrant crisis (Krastev, 2016; Rupnik, 2016), and weak and discredited center-left opposition parties (Berman, 2016). However, a brief comparison suggests these domestic-level explanations alone are insufficient. The 2015 ascent of Poland's PiS has been likened to Fidesz's rise in Hungary. In 2010, Hungary was in the midst of a deep economic recession, the center-left party had been discredited by corruption scandals, and public support for the EU was down. In contrast, Poland was the only EU member that avoided recession after the 2008 financial crisis. In 2015, unemployment was low, corruption rankings had been 
continually improving, and popular support for the EU was around 80\% (Fomina and Kucharczyk, 2016). Despite these contrasting domestic situations, the outcomes in Hungary and Poland have been remarkably similar. This suggests that domestic explanations alone are insufficient.

\subsubsection{Executive Power}

The first way I argue the EU has contributed to backsliding in Hungary and Poland is by increasing relative executive power. Preparations for EU accession were largely executive-dominated in these states in an effort to maintain stability and direct economic crisis management. Furthermore, Hungary and Poland each only had a small team of Euro-experts, concentrated in the executive branch. At the same time, the citizens of these states lacked the information necessary to develop their own interests regarding EU accession (Ágh, 1999). Indeed, as EU integration and democratization preceded, "a tendency towards the central role of the prime minister can be detected" (Fink-Hafner, 2007, 824).

As a result, the legislature in Hungary was rendered exceedingly weak, and little emphasis was placed on popular control and government accountability outside of elections (Rose-Ackerman, 2005; Nikolenyi, 2014). During accession preparations, it was easy for the executive to push EU legislation and policy through parliament "because of the general support for EU accession as well as low interest and expertise of the MPs" (Ágh, 1999, 844). Hungary was effective at adopting legislation but less successful in terms of implementing this legislation and garnering societal support (Ágh, 1999).

The impact of the EU on executive power is not limited to the pre-accession phase. EU scholars have identified the EU's democratic deficit, characterized in part by the fact that European integration and membership result in increased power 
for national executives with a coinciding decrease in parliamentary control (Follesdal and Hix, 2006). All executives of EU member states represent their countries in the European Council, the most powerful political body in the EU (Tallberg, 2008). As European integration has increased, the amount of power the supranational bodies of the EU have over legislation has taken power away from domestic legislatures, thereby further contributing to the trend that executives have more power than their legislatures (Bideleux, 2001). For example, with the implementation of the Economic and Monetary Union, monetary policy decisions are now taken almost exclusively at the EU level. Similarly, the EU has monopolized control of commercial negotiations, with the EU Commissioner for Trade acting on behalf of all member states (Nanou and Dorussen, 2013).

Heightened executive powers without a proportional increase in national parliamentary strength is a particularly relevant factor with respect to democratic backsliding, which often occurs as a result of increased and unchecked executive powers. While in theory this and other aspects of the democratic deficit create the same challenges for all EU member states, its impact is likely greater in states where democracy is newer and thus less institutionalized. Indeed, critics argue the EU exported its democratic deficit to Central and Eastern Europe, producing shallow democracies, and studies have shown that the democratic deficit "has a more visible impact on late accession countries (which are required to adopt a much larger body of European laws and regulations) and on countries with less robust democratic traditions" (Ekiert, 2008, 19).

Another way that EU membership contributes to executive power aggrandizement is through transnational party politics, which can provide state executives with transnational allies and thus prevent the $\mathrm{EU}$ as a whole from sanctioning attacks against democratic institutions. To date, the EU has been relatively unsuccessful in 
punishing political non-compliance, or the violation of democratic political criteria on which membership in the organization is conditioned. ${ }^{33}$ One proposed explanation for this lack of action on the part of the EU is related to party politics at the supranational level. The European Parliament is composed of transnational parties, known as European party groups, which are political groups composed of representatives from a number of European countries; European party groups are ideologically organized and have become increasingly cohesive over time (Hix et al., 2007). As their cohesion has increased, so too has the likelihood that these transnational parties will act as advocates for their own members, even those from other countries. Indeed, the European People's Party Group has effectively blocked attempts (until the vote in 2018) by the European Parliament to take action against Orbán and the Fidesz party in Hungary (Jenne and Mudde, 2012; Kelemen, 2017).

Comparisons between Western Europe and Hungary and Poland demonstrate the impact that the EU has on governmental balance of power in new democracies. Figure 5.9 compares four measures of executive constraints in Western Europe, Hungary, and Poland. The solid line represents annual averages of these variables for the 15 Western European countries that were members of the EU prior to 2004, while the dashed and dotted lines trace the indices over time in Hungary and Poland. The legislative constraints variable measures the extent to which legislatures and other government agencies are capable of executive oversight. The legislature investigates executive measure traces the degree to which, in practice, legislatures investigate unconstitutional or illegal activities by the executive. The judicial constraints variable takes into account the extent to which executives respect the constitution and judicial

\footnotetext{
${ }^{33}$ Although the European Parliament voted in 2018 to sanction Hungary for its undemocratic turn, it is not yet clear if this vote will translate into any substantial action.
} 
independence. Finally, the fourth plot measures executive respect for the constitution (Coppedge et al., 2018). Overall, intra-governmental power relations favor the executive to a greater extent in Hungary and Poland than in Western Europe.

The EU also increases executive power via its emphasis on bureaucratic, technocratic, and legal institutions, as opposed to democratic ones. In the 1990s and early 2000s, Hungary and Poland had to develop administrative structures to demonstrate their ability to function within the EU's complex multi-level governance system, and the European Commission stressed a professional civil service as a key requirement for membership. As a result, although initially the focus in Hungary and Poland was on democratic institutions, by the end of the 1990s the attention had shifted to building a bureaucracy (Dimitrova, 2002).

Throughout the accession process, the EU was the largest source of aid and technical assistance for Hungary and Poland (Grabbe, 2001). Poland and Hungary: Aid for Economic Restructuring (Phare), the largest source of pre-accession aid, was a program aimed to help candidate countries fulfill the requirements of the Copenhagen Criteria and the acquis. On average across the region, $30 \%$ of Phare was devoted to institution building, with the goal of improving states' capacity to implement the acquis, while the other $70 \%$ was devoted to financial investments "to strengthen the regulatory infrastructure needed to ensure compliance with the acquis and to reinforce economic and social cohesion" (European Commission, 1999, 7). Phare was also used in a more bottom-up manner to fund non-governmental organizations in the candidate states to bolster civil society. This bottom-up aspect of Phare produced limited success in Hungary and Poland, two states with already exceedingly weak civil societies (Rose-Ackerman, 2005). 
Legislative Constraints on Exec.

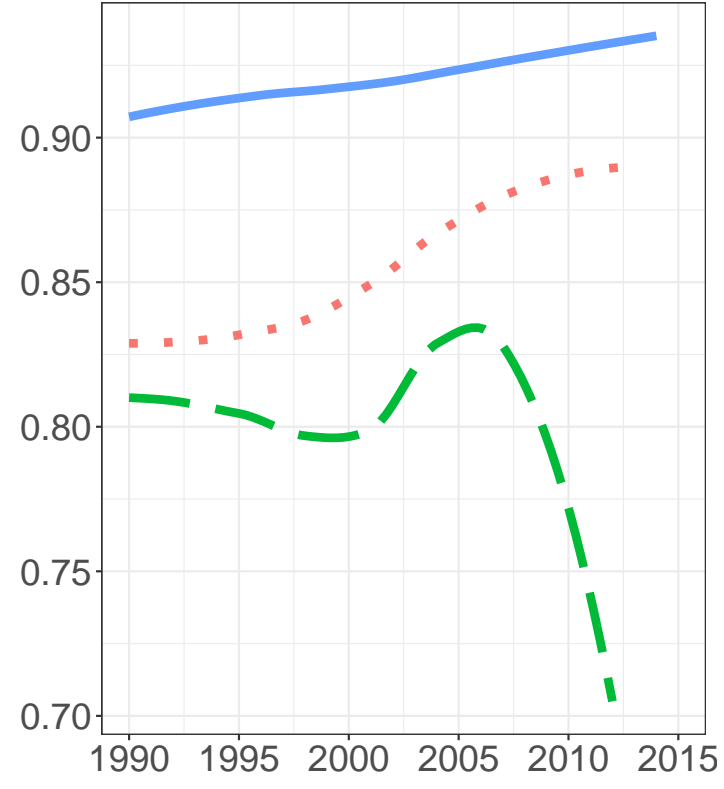

Legislature Investigates Exec.

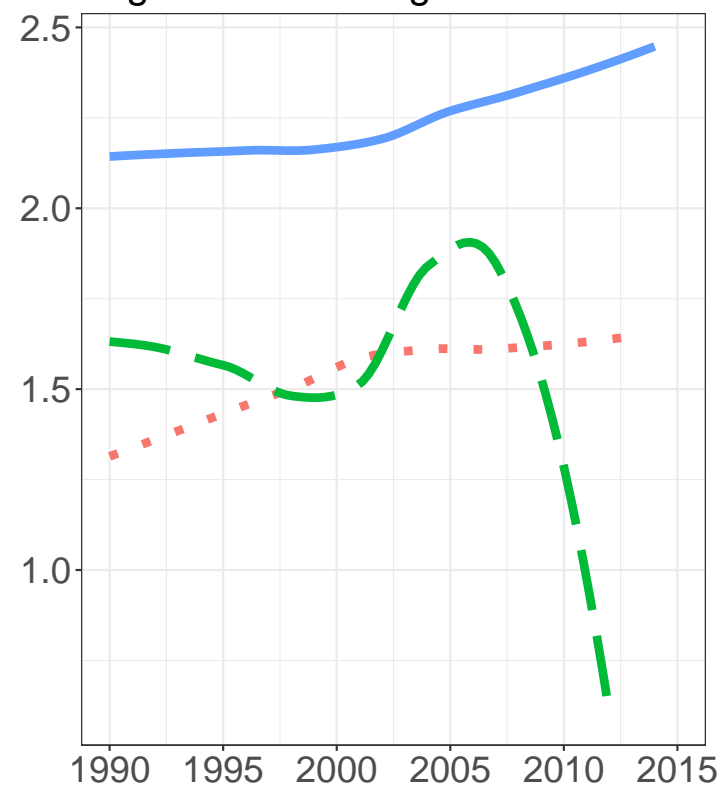

Judicial Constraints on Exec.

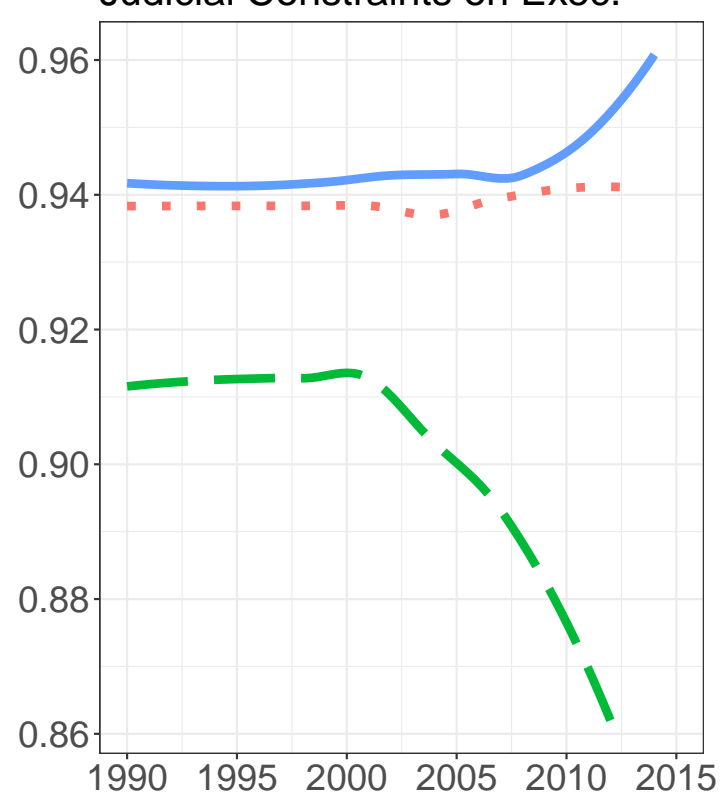

Exec. Respects Constitution

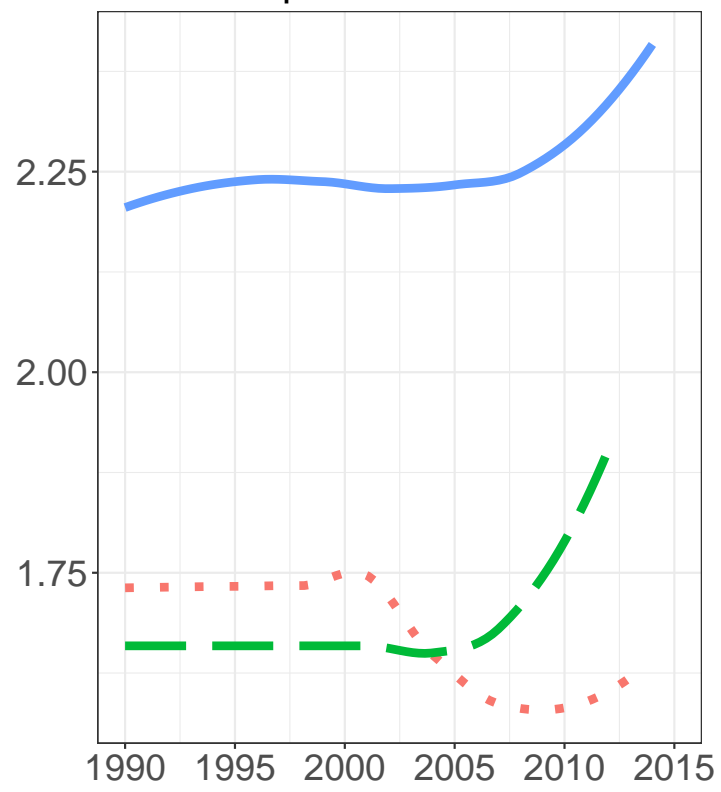

Figure 5.9: On average, western European legislatures and judiciaries have more control over their executives, and executives in the West adhere to the constitution more closely than their counterparts in Hungary and Poland. 
In addition to Phare, the EU created two other aid programs for candidate countries, which began in 2000: SAPARD and IPSA. SAPARD provided aid for agricultural and rural development, while IPSA funds were targeted toward environmental and transportation infrastructure projects (European Commission, 2000). In other words, EU aid to Hungary and Poland was predominantly and almost exclusively focused on bureaucratic and administrative offices, with little or no attention given to truly democratic institutions.

The primary mechanism that Phare used for institution building and knowledge transfer was known as "twinning." Twinning was a tripartite initiative between the Commission, member states, and candidate countries that involved sending civil servants from member states' administrations to candidate countries' administrations and bureaucracies to help them with adopting the acquis. Reflecting the EU's bureaucratic approach to democracy promotion, the twinning project was undergirded by the assumption that institutions can be set up in a top-down manner rather than being gradually learned (Bailey and de Propris, 2004). 
Table 5.2: Pre-Accession Aid (Phare) Allocation in Hungary and Poland, 1999-2002

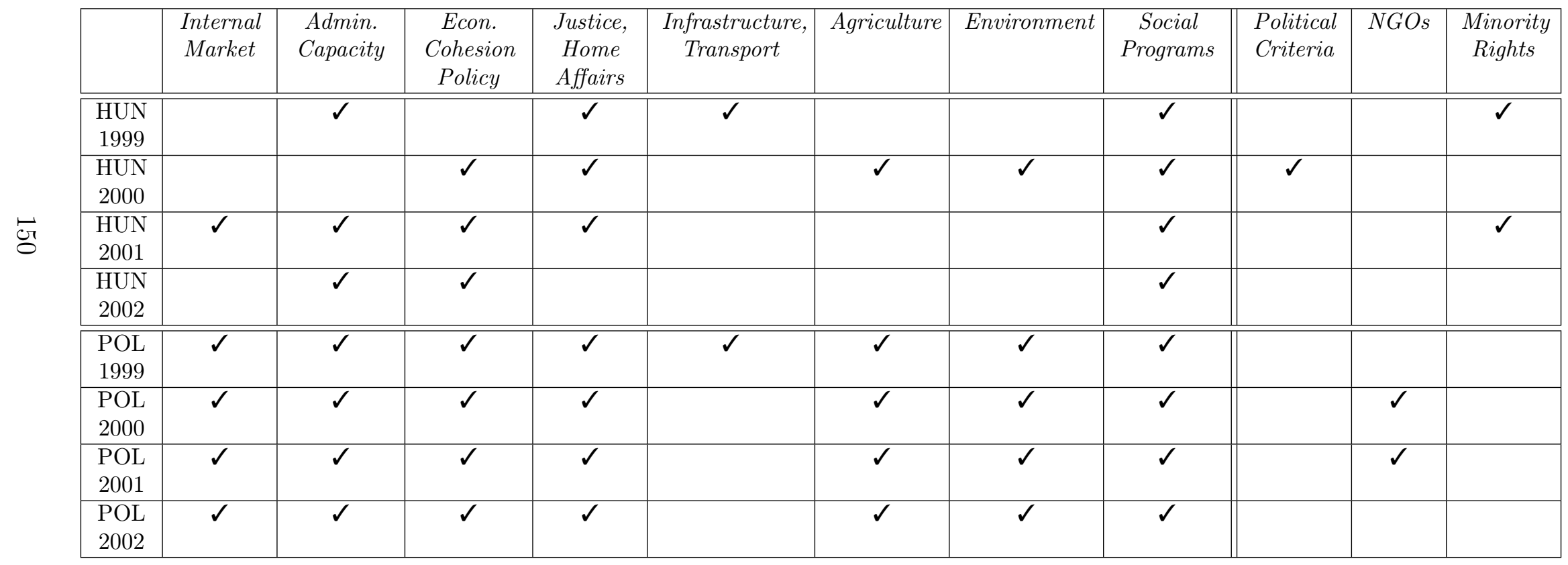


The heavily bureaucratic focus of the EU accession process is further highlighted by the allocation of aid given to Hungary and Poland. Between 1999 and 2002, Hungary received $€ 379.17$ million from Phare for national-level projects, while Poland received $€ 1.3967$ billion. Table 5.2 provides an overview of how these funds were allocated in each country. Phare funding was predominantly focused on bureaucratic projects linked to the acquis rather than on strengthening key democratic institutions. In particular, these resources went to the creation of institutions necessary for the EU internal market, general administrative capacity, implementation of the EU's economic cohesion policy, border and migration policy (Justice and Home Affairs), infrastructure, agriculture, the environment, and social programs such as education (European Commission, 2002a,b).

Phare was not only heavily bureaucratic but also limited in its ability to provide aid. The pre-accession financial aid provided to Hungary and Poland-and to postcommunist Europe as a whole - was significantly less than that provided to Spain and Portugal during their accession processes (Rose-Ackerman, 2005). This was due to the fact that there were too many post-communist states for the EU to provide adequate aid to all. Thus, while the EU had more extensive accession requirements for the post-communist states than any previous candidate states, it also had less funds available to offer these countries for implementing these requirements (Bailey and de Propris, 2004).

In addition to focusing significant attention on the task of building bureaucratic institutions, the EU also heavily emphasized legal constitutionalism, which had a perverse impact on constitutional structures in the new democracies in post-communist Europe (Blokker, 2013). Constitutional democracy emerged in this region around the same time that these states were being integrated into and influenced by the EU. As a result, the constitutions that emerged were strongly influenced by external pressure. 
The legal constitutionalism and corresponding neutral institutions that developed emphasize the legal over the political (Rupnik, 2007) and therefore contribute to the relatively shallow nature of representative domestic institutions in these countries.

The emphasis that the EU places on bureaucratic and legal, rather than democratic, institutions is closely linked to the EU's democratic deficit, another component of which is that policy making in the EU is undertaken in a largely technocratic way by an "enlightened bureaucracy," rather than by democratically elected institutions (Follesdal and Hix, 2006). This technocratic aspect of the Union is passed along to candidate states.

The EU's bureaucratic orientation, and corresponding inability to promote truly democratic institutions, is reflected in its response to democratic backsliding. Thus far, the EU's response to increasing illiberalism in Hungary and Poland has been fragmented. In addition to the barriers posted by supranational party politics, part of the problem lies in the fact that the EU has a limited toolkit at its disposal for punishing member states, especially when it comes to political non-compliance with EU democratic standards. Prior to granting membership, the EU is able to use the carrot of membership to incentivize states to uphold democratic conditions. However, after accession, the EU's leverage diminishes, in large part due to the fact that there are no mechanisms by which membership can be revoked and also because the sanctions available to the EU for political violations are relatively weak (Jenne and Mudde, 2012). The one exception is Article 7 of the Treaty of the European Union, which gives the European Commission the power to revoke certain membership privileges, such as voting rights in the European Council, for "serious and persistent breaches of democratic principles" (Sedelmeier, 2014, 106). Although in 2018 the European Parliament did finally vote to invoke Article 7 against Hungary, any action 
would require an unanimous vote within the European Commission. This is quite unlikely, given that Poland also has a representative in the Commission.

\subsubsection{Domestic Policy Space}

In addition to increasing relative executive power, the EU further contributes to democratic backsliding in its member states by limiting the domestic policy space, which stunts institutional development, including institutions that reign in executive power. EU membership conditionality requires candidate countries to comply with the Copenhagen Criteria and the acquis. One side-effect of these conditions, which were exceedingly more extensive for the post-communist countries than they had been for any of the previous enlargement groups, was that they severely constrained the domestic policy space; this was especially the case in Poland, Hungary, and the Czech Republic. Ironically, since these three states did the most "to hew to the EU line and accept EU demands, they have been least able to debate the future of their state" (Grzymalaa-Busse and Innes, 2003, 69). This, in turn, constrained the evolution of party competition in these countries, with most parties responding to EU leverage by advocating agendas that aligned with EU requirements. Since so many policies were dictated directly by the EU, policy debates in these states were and continue to be largely based on valence issues and secondary policy concerns, with parties distinguishing themselves from one another merely by disputing each other's managerial competence in implementing EU-prescribed policies rather than debating substantive program alternatives or ideological issues. ${ }^{34}$

\footnotetext{
${ }^{34}$ Vachudova also finds that political parties in post-communist Europe adopted platforms aligned with EU requirements during the pre-accession phase, converging on right-leaning economic policies, such as a free market economy, and libertarian social issues, including support for human and minority rights. Vachudova views this pre-accession convergence as positive, since it disadvantaged the formation of illiberal political parties. I take her argument one step further, contending that, although EU policy mandates curtailed illiberalism in the pre-accession phase, they made illiberal policies more prevalent in the post-accession period. This is because pre-accession convergence produced underdeveloped party systems characterized by parties that campaign on valence issues.
} 
One result of further EU integration has been the reassignment of many policy competencies from the domestic to the EU level and a convergence of national party platforms in EU member states (Nanou and Dorussen, 2013). To illustrate, today, none of the leading parties from the 1990 Hungarian election are electorally competitive at the national level. The year 1998 was the last time that any parties in Hungary that had competed in the first democratic election won more than $10 \%$ of the national vote. Since 2010, Hungarian politics has been dominated by Orbán's Fidesz party and the far-right, Jobbik. Limits to the domestic policy space played a role in weakening the political left, leaving Fidesz to govern unopposed. Similarly, of the parties that received at least $10 \%$ of the national vote in Poland in the first three elections, only one has surpassed this $10 \%$ threshold since 1997. Since 2007, Poland's party system has been dominated by PiS (conservative) and Civic Platform (liberal). Many of the earlier Polish parties were social democratic parties, yet none of these has surpassed $10 \%$ since 2005. Several agrarian parties were also prominent early on; these too have been largely absent.

The topics included in parties' manifestos illustrate the limits the EU places on domestic policy. Party systems in mature democracies form when parties compete along salient socio-political cleavages based on economic, social, and nation-based issues (Lipset and Rokkan, 1967). Parties in less developed party systems, however, compete primarily on valence issues (Kitschelt et al., 1999). The Comparative Manifesto Project (CMP) contains data on the content of parties' manifestos for every election year in their respective country; these data measure the percentage of quasisentences of manifestos devoted to a topic (Volkens et al., 2017). The manifestos Indeed, Vachudova finds that, when the parameters for party competition broadened following accession, more parties began adopting nationalistic and other culturally conservative policies (Vachudova, 2008). 
provide useful measures of the types of issues parties debate and the relative emphasis they place on different topics. Manifestos capture the extent to which an issue is salient to a party and "may actually canvass party wishes more than do activities in power, where initiatives reflect constraints and demands of coalition partners" (Burgoon, 2012, 616). As such, the CMP is a useful measure of a state's domestic policy space and the extent to which parties appeal to voters based on substantive policy issues.

The CMP data identify 56 categories of manifesto topics. To measure the extent to which parties in Hungary and Poland debate substantive policies, I isolate the 22 topics that are directly related to economics, government intervention in the economy, or social issues defined in economic terms (Ward et al., 2015). Specifically, this includes all issues in Domain 4 (Economy) as well as welfare state expansion, welfare state limitation, labor groups, and agriculture and farmers (Volkens et al., 2017). The remaining 34 topics are non-economic and less policy-relevant; these include issues such as nationalism, corruption, law and order, and European integration. Using the 22 economic topics, I create two variables. The first measures the percent of manifestos devoted to economic issues and the second the percent devoted to noneconomic issues.

Figure 5.10 traces the extent to which parties in Hungary and Poland, on average over time, reference substantive economic and non-economic policies. ${ }^{35}$ Overall, economic issues have been less prominent than non-economic issues in each election since Hungary and Poland transitioned to democracy. The emphasis on non-economic

\footnotetext{
${ }^{35}$ To draw the lines for the plots in Figure 5.10, I find the percent that each party in a given country devotes to the economic and non-economic topic in their manifesto in any given year. I then calculate the average percentage for all parties in a country for that year; this value is the point plotted on the graph. Finally, I use lines of best fit, one for Hungary and one for Poland, to show changes over time.
} 
issues grew following EU accession. In the last Hungarian election for which manifesto data are available (2014), the average emphasis on non-economic issues was $61 \%$ compared to only $39 \%$ for economic ones; similarly, in Poland in 2011, $70 \%$ of manifestos were devoted to non-economic issues, while only $30 \%$ discussed economic ones.

These trends are in stark contrast to parties in mature democracies. Figure 5.11 compares the extent to which parties in Hungary, Poland, and Western Europe include mentions of economic and non-economic issues. The lines for Hungary and Poland are the same as those in Figure 5.10; for the Western Europe lines, I average across party manifestos from the 15 countries that were EU members prior to 2004. During this time period, mentions of economic issues have declined in Hungary and Poland, while non-economic discussions have increased. In Western Europe, the opposite is true.

Comparing parties in Hungary and Poland to those in Western Europe both today and in the past shows that Hungarian and Polish parties on average focus much more on valence issues in their party platforms than parties in Western Europe do today or ever did. One defining characteristic of underdeveloped party systems is parties that compete primarily based on valence issues (Kitschelt et al., 1999). This provides preliminary evidence that the EU's reduction of the domestic policy space in Hungary and Poland stunted party system development.

When Hungary and Poland began formal negotiations with the EU in 1998, the topics that dominated party manifestos shifted. EU requirements pushed parties to adopt economic policies traditionally associated with the right and social policies that align with green, alternative, and libertarian dimensions (Vachudova, 2008). One chapter of the acquis is devoted to social policy and employment, with an emphasis on social protection. In the 1998 Hungarian election, four parties surpassed $10 \%$ of 

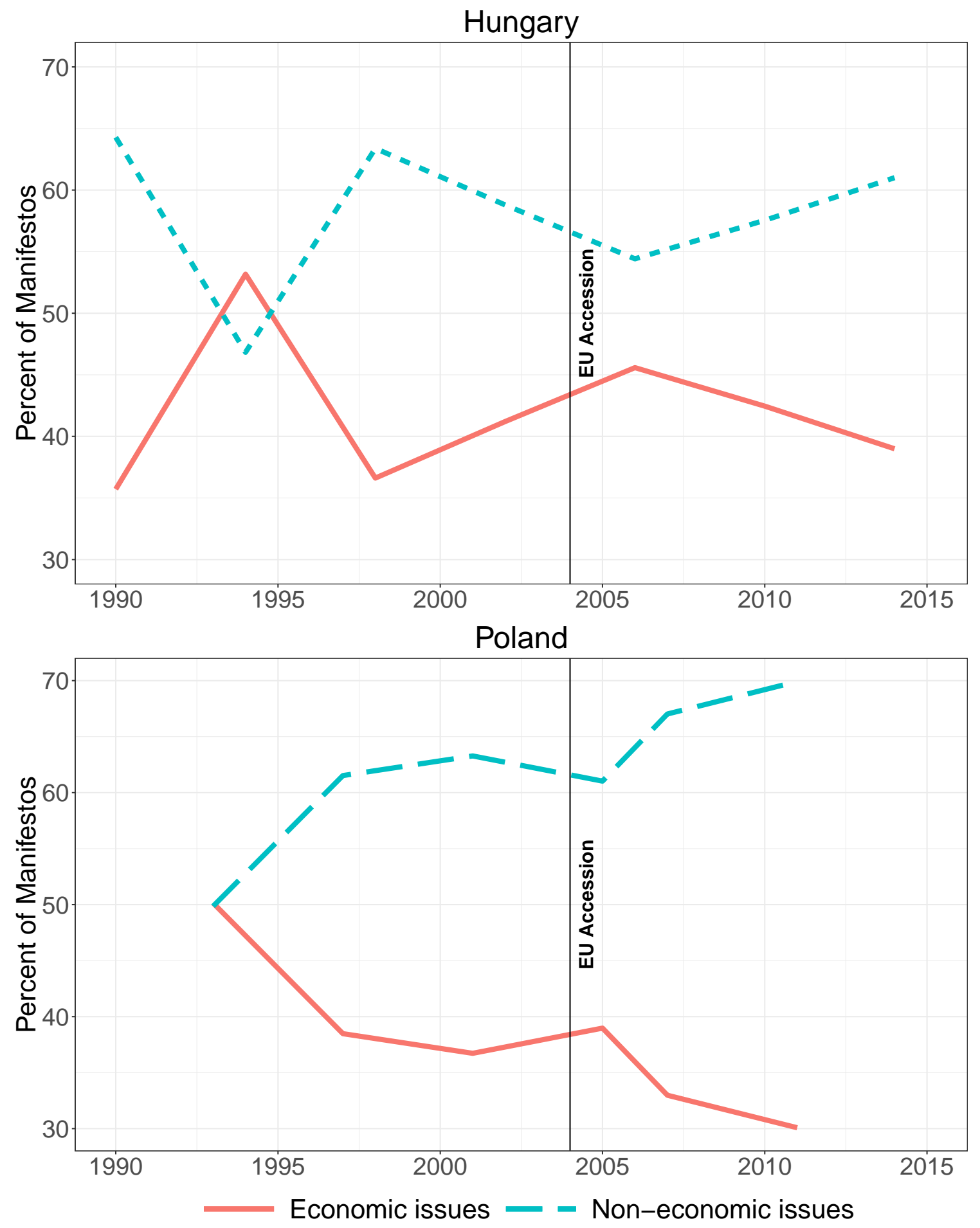

Figure 5.10: Economic issues are less prominent than non-economic ones in Hungarian and Polish party manifestos. The emphasis on non-economic issues became particularly strong following EU accession. 

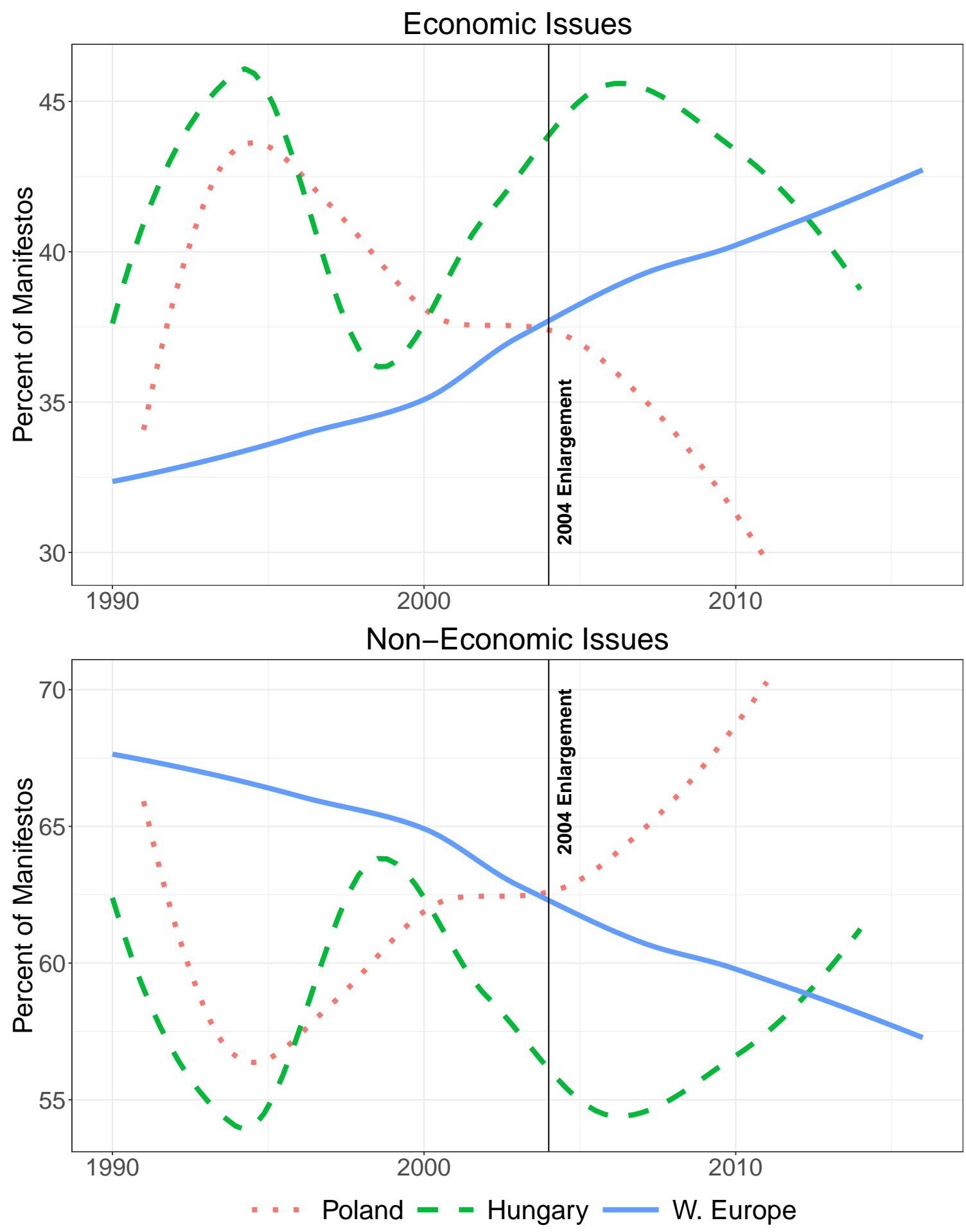

Figure 5.11: At the same time that mentions of economic issues have been on the decline in Hungary and Poland, western European parties on average have given increased attention to these same topics. Similarly, while mentions of non-economic issues in Hungary and Poland have steadily risen, they have been decreasing among western European parties. 
the vote: the Independent Small Holders Party (agrarian), the Hungarian Democratic Forum (Christian democratic), the Hungarian Socialist Party (social democratic), and the Fidesz-Hungarian Civic Union coalition (conservative). With the exception of the Independent Small Holders Party (which, notably, has not surpassed 10\% since 1998), all successful parties in 1998 devoted significant attention to welfare state expansion.

The 1998 Hungarian Democratic Forum's manifesto was the only one that devoted as much attention to welfare state retrenchment as it did to expansion. It seems that this divergence from EU policy was not without its problems: 1998 was the last election where the Hungarian Democratic Forum received more than $10 \%$. Widespread support for welfare state expansion continued in the 2002 and 2006 Hungarian elections. Other prominent policy areas included in the membership acquis are agriculture, education, regional policy (Grabbe, 2001), and the environment. Successful Hungarian parties during this time period - namely, the Socialist party and Fidesz, following 1998 - devoted significant attention to these topics.

Discussions of other economic issues were less prevalent. The EU emphasizes the free movement of goods, workers, services, and capital, which contribute to the overall functioning of the European single market. The importance of maintaining the single market is such that "policy decisions that interfere with the free market are prohibited" (Quaglia et al., 2007, 417). For example, while in 1998 the Hungarian Socialist party and the Hungarian Democratic Forum advocated market regulation (5.3\% and $6.9 \%$, respectively, of their manifestos), by 2002 all references to regulation had disappeared. Indeed, amongst the parties that were competitive at the national level between 1998 and 2010, economic debates were often uncritical and focused on incentives for businesses, support for economic growth, and vague economic goals. Parties adopted few substantive economic policy positions during the accession period; instead, the focus was on valence issues. 
Similar trends emerged in Poland. In party manifestos from 1991 and 1993, valence topics were less common among the parties that received over 10\% of the vote. Parties discussed a wide range of economic policies, such as market regulation, support for government economic policy making, protectionism, decentralization of the state, supply- and demand-side oriented economic policies, and market regulation. The topics in successful Polish parties' manifestos evolved as negotiations with the EU began. In the 1997 election, EU policies such as welfare state expansion, technology and infrastructure, and education expansion were prominent. Other economic issues, such as supply-side incentives, market regulation, and economic orthodoxy were also included but to a lesser extent than previously. Instead, the 1997 manifestos focus more on valence issues.

This trend continues and intensifies in 2001 and 2005. The economic issues discussed were uncontroversial and consisted of vague economic goals and support for economic growth. Parties in these elections that advocated more controversial economic issues, such as protectionism (Self-Defense of the Republic of Poland in 2001), market regulation (Democratic Left Alliance in 2005), and a controlled economy (SelfDefense of the Republic of Poland in 2005), have not surpassed 10\% since 2005.

Indeed, the only two parties that have been above $10 \%$ since 2005 are PiS and the liberal Civic Platform party. In 2007 and 2011, these parties emphasized EU policies and valence issues. PiS devoted over 35\% of its 2011 manifesto to discussing its ability to lead, the opposition's inability to govern, government efficiency, culture, and law and order; only $6.5 \%$ focuses on substantive economic issues. In the same election, Civic Platform devoted almost $27 \%$ of its manifesto to government efficiency, governing capability of the party, culture, and civic mindedness, yet only $7.4 \%$ discussed economic issues outside of the expansion of the welfare state, technology, and infrastructure. 
EU policy constraints may indeed have contributed to the collapse of the political left by encouraging a race to the bottom. In the early 1990s, Hungary's liberal party, the Alliance of Free Democrats, was second only to the Christian Democratic party in terms of votes, trailing by $5 \%$. In 1994, the Alliance of Free Democrats and the Hungarian Socialist Party were the top two parties. By 1998, an alliance between these parties resulted in the Socialist party emerging as the front-runner in terms of votes in the 1998 and 2002 elections. However, in the 2006 election, the Socialist party's support began to wane, and its credibility was shattered by the 2008 corruption scandal (Herman, 2015). After winning only 21\% in 2010, the Socialist party has since failed to garner more than 10\% (Kollman et al., 2016; Volkens et al., 2017).

Since 2006, the conservative Fidesz and far-right Jobbik parties have dominated Hungarian politics. In 2010, no left-of-center party received more than $10 \%$ of the vote. The situation only improved slightly in the 2016 election, where a center-left coalition of five political parties (collectively called Unity) won 26.2\% (Kollman et al., 2016).

Similar patterns have emerged in Poland:

As the region-wide tax competition deepened, spurred on by the EU's crackdown on subsidies, not only did Poland's liberal left lose its margin for any credible economic policy in social justice terms, but over time they also lost the institutional requirements for more co-ordinated economic solutions, as union density fell and unions were estranged by radical liberal labour market policies. (Innes, 2014, 96)

The decline of Poland's political left is also linked to region-wide tax competition for foreign direct investment, resulting in a "race to the bottom" with respect to tax levels. This weakens the position of the parties of the left, which tend to espouse higher taxes and partially regulated markets. By limiting these parties' ability to 
compete in domestic politics, European economic integration weakened the left and facilitated the rise of center-right, populist parties in Hungary and Poland.

To summarize, this chapter argues that the EU's post-Maastricht policy structure, accession process, and membership requirements make democratic backsliding more likely in new democracies by simultaneously augmenting executive power and by limiting states' domestic policy space, which stunts institutional development. In addition to offering an explanation that complements existing research on the domestic sources of backsliding in Hungary and Poland, the argument about the impact of the EU on representative democratic institutions, especially political parties, is also relevant to mature democracies in the EU. Membership in the EU limits the domestic policy space of states. Although the consequences may not be as dire in democracies where parties were developed and institutionalized prior to EU membership and integration, the restrictions that the EU places on policy may still have adverse effects in these older member states. Indeed, populism and other challenges to liberal democracy have been on the rise throughout Europe (Krastev, 2016; Pappas, 2016), leading some to predict the impending de-consolidation of long-established democracies (Foa and Mounk, 2017). 


\section{Chapter 6: Conclusion}

Today it is becoming increasingly apparent that democracy, and especially liberal democracy, is struggling and in some cases even failing; however, existing theories of democracy are unable to explain these trends. Democratization and institution building are slow processes that occur gradually and are often fraught with instability; however, they are ultimately critical for long-term democratic quality and survival. Particularly since the 1980s, the international community has focused primarily on elections and elite compliance with democracy, regardless of the domestic institutional context, to promote and support democracy (Carothers, 2002). However, elections without strong institutions have limited democratizing potential (Flores and Nooruddin, 2016).

This dissertation investigates the unintended consequences of democracy promotion by international organizations (IOs) as one source of democratic backsliding, emphasizing the institutional pre-requisites for democracy to succeed. Democratic backsliding occurs when elected officials weaken or erode democratic institutions, resulting in an illiberal or diminished form of democracy, rather than autocracy. Since the end of the Cold War, IOs have engaged in unprecedented levels of democracy promotion and are widely viewed as positive forces for democracy. However, this increased emphasis on democracy by IOs has been accompanied by a sharp rise in cases of democratic backsliding in new and emerging democracies. 
Existing research identifies a positive relationship between IOs and democracy (Pevehouse, 2005; Poast and Urpelainen, 2018) but tells us less about how these organizations impact domestic democratic institutions that influence a state's quality of democracy in the long term. Building on this work, this dissertation asks: why are an increasing number of new democracies backsliding despite support from and membership in the types of IOs often linked to democratic progress and even democratic consolidation? I argue and find evidence that, although IOs are associated with democracy in the aggregate, they are ill-equipped to promote ongoing democratic progress or consolidation, and they can even unintentionally contribute to backsliding. The reason for this can ultimately be linked to the characteristics of successful democracies, which require institutions that organize mass participation in politics, increase government effectiveness, and limit state power (Huntington, 1968).

Specifically, I argue that these IOs contribute to democratic backsliding in new democracies by altering domestic institutional configurations via three interrelated mechanisms. First, IOs focus predominantly on elites and elections to the neglect of other institutions paramount to democracy. Such institutions include those that organize mass participation in politics, aggregate social interests, enable the state to govern effectively, and, critically, limit government power. In addition to indirectly increasing the probability of backsliding by neglecting important democratic institutions, I argue that IOs more directly contribute to democratic backsliding in new democracies by increasing executive power and by limiting the domestic policy space via membership requirements. Limited policy options stunt representative institutional development and make it difficult for rulers to govern. Unable to appeal to voters based on records of effective governance or policy alternatives, executives manipulate weak institutions to maintain power, thus increasing the likelihood of backsliding. 
Empirically, this dissertation makes several contributions. First, existing measures of regime type distinguish between countries by focusing on minimalist characteristics of democracy, such as elections, yet do not capture the strength of other democratic institutions. As such, these commonly used indicators distinguish between autocracies and democracies but cannot capture subtle differences among democracies, such as those that result from democratic backsliding. Therefore, I develop an original indicator of democratic backsliding: the Democratic Institutional Strength (DIS) index. The DIS index is a theoretically based conceptualization of democratic backsliding, an increasingly important concept for which there has been no previous metric. I combine the DIS index with original and existing data on IO characteristics and membership and find that membership in three types of IOs commonly associated with democratic success - democratically committed, political or economic, and interventionist IOs - is linked to an increased likelihood of democratic backsliding, decreased checks on executive power, and limited economic policy options and party development in new democracies.

Case studies of backsliding in the European Union (EU) illuminate these mechanisms. Using process tracing, comparative case studies, and the synthetic control method, I trace backsliding in Hungary and Poland, two states that were subject to extensive EU accession requirements. I contrast Hungary and Poland with two canonical third wave democracies in the EU: Spain and Portugal. For these states, which have not undergone democratic backsliding, membership conditionality was much less extensive, occurred on much more of an ad hoc basis, and required the adoption of far fewer domestic policies. Finally, since Spain and Portugal only approximate the counterfactual, I also develop synthetic case studies, a data-driven approach to estimating counterfactuals, and find evidence suggesting that EU accession had a negative treatment effect on Hungary's subsequent democratic trajectory. 


\subsection{Extensions and Areas for Future Research}

The theory and findings presented here suggest a number of avenues for future research. First, case studies of additional democracy promoting IOs, in addition to the EU, would further bolster confidence in these findings. The Organization of American States (OAS) in Latin America is a particularly relevant additional example. Like the EU, the OAS has developed elaborate structures for promoting democracy, and it operates in a densely democratic, relatively economically prosperous region where democracy should be likely to thrive. Despite these characteristics, members of the OAS, including Bolivia, Ecuador, and, to a much greater extent, Venezuela, have all recently shown signs of backsliding. To what extent, if any, has the OAS's involvement in these states increased relative executive power and limited domestic policy options?

Second, although the focus here is on the ways in which democracy support and promotion by IOs specifically unintentionally contribute to backsliding in new democracies, future research should investigate the role of other international actors that engage in democracy promotion as well. Foreign aid for democracy, election monitoring, and democracy promotion by governmental and non-governmental organizations are other examples of international sources of democracy that likely impact developing countries' regime outcomes.

Next, this dissertation focuses primarily on the role of elites in cases of democratic backsliding. Although elites are the critical instigators of backsliding, and thus an appropriate starting point for research on this emerging phenomenon, this is an incomplete story; the citizen response to backsliding is also crucial. Future research should expand the analysis here to also incorporate survey data on mass attitudes toward democracy and study how these attitudes change in response to executive power grabs and democratic backsliding. Other relevant surveys could also measure 
citizens' attitudes toward democracy promoting international actors: do mass attitudes toward democratically committed IOs change over time, between the accession and membership phases? Do these attitudes translate into action? Do they subsequently impact executive behavior?

The citizen response to backsliding is just one of many important domestic factors to consider. It is critical to identify the other domestic institutions that mediate the relationship between membership in democratically committed IOs and democratic backsliding in new democracies. Although I find evidence that increased membership in these organizations makes backsliding more likely, international variables are only one part of the story. Given that many new democracies are members of these IOs but have not experienced backsliding, there are undoubtedly domestic characteristics that condition the extent to which these international forces have deleterious impacts on domestic regime outcomes. My DIS index provides one way for future researchers to more systematically test nascent theories about the domestic sources of democratic backsliding, which highlight the central role that executives play in triggering backsliding (Fish, 2001; Van De Walle, 2003), as well as suggesting how the collapse of social-democratic and center-left parties (Berman, 2016; Fomina and Kucharczyk, 2016; Krastev, 2016; Innes, 2014), coupled with the rise of more extreme parties (Lochocki, 2016), have also contributed to recent democratic erosions.

It is also important to understand how IOs affect developing states' regime trajectories after states become members. When their member states backslide, do these democratically committed IOs react, exert pressure, or simply lose leverage and cease to influence domestic-level outcomes? Under what circumstances, if any, can international actors protect democracy? Do supranational institutions within the EU fuel or hinder the spread of democratic backsliding across member states? Data on sanctions levied by democratically committed IOs against member states for violation of 
political conditions for membership could begin to answer these questions. Furthermore, analyzing voting patterns in the European Parliament could reveal the extent to which transnational political affiliations influence domestic parties' campaigning strategies within EU member states.

Finally, this dissertation investigates the unintended consequences of democracy promotion as one source of democratic backsliding. However, this is just one example of how increasing levels of globalization have changed democracies' domestic political contexts and altered the strategies governments adopt for implementing policy, contesting elections, and staying in power. Further work is needed to investigate the other challenges that globalization poses for democracy in both new and more mature democracies. Is the rise of the populist radical right in the United States and France, for example, comparable to cases of populist-driven democratic backsliding in new democracies, such as Hungary and Poland? What explains cases of democratic backsliding in states that are not members of democracy promoting IOs, such as Turkey? Is there evidence of the mechanisms driving backsliding that I propose in my dissertation (namely, weak domestic institutions that are unable to check executive power) in all cases of backsliding? Are these weak institutions products of globalization? Free trade agreements, economic policy homogenization, and international financial institutions similarly limit states' domestic policy space, hinder or alter the development of state institutions, change incumbents' incentives, increase mass support for anti-democratic populists, and in general make liberal democracy more difficult to sustain.

\subsection{Policy Implications}

This project also suggests that ongoing efforts at democracy promotion by IOs, and the international community more broadly, need to be altered if new democracies 
are to continue to flourish. Attempts to accelerate the process of democratization risk creating states where citizens participate in politics, but state institutions are unable to effectively represent mass interests or govern effectively. The result is a procedurally democratic state yet one where human and minority rights, judicial independence, media freedom, and other liberal aspects of society are weak and susceptible to manipulation by elected officials.

What are the policy implications for IOs? Widespread international support for universal suffrage and basic human rights precludes encouraging slow transitions to democracy that approximate the long and often violent processes that characterized earlier waves of democracy. Furthermore, globalization and increased economic integration make it difficult for states to gradually modernize and build institutions in isolation from external influence. Instead, the findings here suggest IOs should devote more resources to institutional design in new democracies. Doing so will require international democracy advocates to diversify their democracy promoting portfolios and to reallocate the extensive efforts currently devoted to elections and support for executives to other democratic institutions. Rather than treating elections as the first and most important stage of democracy, international actors should instead view elections, which will become increasingly free and fair as institutions develop to regulate and enforce them, as the culmination of the democratization process (Rustow, 1970). In addition, the results suggest IOs should shift to gradually imposing policy requirements on new democracies, rather than requiring states to adhere to an extensive list of conditions during the early years of democratic institutional development. By both directly and indirectly supporting institutional development outside of elections, IOs may be able to offset the challenges faced by young democracies.

However, IOs are only one part of a larger problem with recent efforts at international democracy promotion. The findings also have implications for democracy 
promotion efforts more broadly, including attempts at more direct democracy promotion, such as the United States' involvement in Iraq in the early $21^{\text {st }}$ century. In addition to IOs, it has become increasingly common for states, such as the United States, as well as non-governmental and state-based organizations, such as the United States Agency for International Development (USAID), to take extensive measures to promote democracy as well. The findings in this project suggest that it is insufficient for external actors to simply impose elections in a state without other critical democratic institutions - such as developed party systems, strong legislatures, independent judiciaries, and a robust civil society - and expect democracy to be successful. There are limits to these external efforts at democracy promotion; without a rather extensive level of bottom-up democratization to accompany external aid and democracy promotion, it is unlikely that anything beyond a superficially democratic regime will take hold.

Contemporary cases of democratic backsliding and stagnation, as well as the rise of populism and illiberalism, suggest that liberal democracy is under threat. However, existing theories of democracy, which tend to focus on structural pre-requisites for democracy and causes of democratic collapse, are unable to explain this empirical shift. By highlighting the institutional pre-requisites for democracy to succeed, and studying how increased international interdependence and globalization alter states' domestic political contexts, this project offers an approach for understanding the sources of, and potential remedies for, contemporary challenges to liberal democracy. 


\section{Bibliography}

Abadie, A., Diamond, A., and Hainmueller, J. (2011). Synth: An R Package for Synthetic Control Methods in Comparative Case Studies. Journal of Statistical Software, 42(13).

Abadie, A., Diamond, A., and Hainmueller, J. (2015). Comparative Politics and the Synthetic Control Method. American Journal of Political Science, 59(2):495-510.

Abadie, B. A. and Gardeazabal, J. (2003). The Economic Costs of Conflict: A Case Study of the Basque Country. The American Economic Review, 93(1):113-132.

Acemoglu, D. and Robinson, J. A. (2005). Economic Origins of Dictatorship and Democracy. Cambridge University Press, Cambridge, MA.

Adcock, R. and Collier, D. (2001). Measurement Validity: A Shared Standard for Qualitative and Quantitative Research. American Political Science Review, 95(3):529-546.

Ágh, A. (1999). Europeanization of policy-making in East Central Europe: the Hungarian approach to EU accession. Journal of European Public Policy, 6(5):839-854.

Ahmed, F. Z. (2012). The Perils of Unearned Foreign Income: Aid, Remittances, and Government Survival. American Political Science Review, 106(1):146-165.

Alesina, A., Devleeschauwer, A., Easterly, W., Kurlat, S., and Wacziarg, R. (2003). Fractionalization. Journal of Economic Growth, 8:155-194.

Allansson, M., Melander, E., and Themner, L. (2017). Organized violence, 1989-2016. Journal of Peace Research, 54(4).

Almond, G. and Verba, S. (1963). The Civic Culture: Political Attitudes and Democracy in Five Nations. Sage Publications.

Andrews, D. M. (1994). Capital Mobility and State Autonomy: Toward a Structural Theory of International Monetary Relations. International Studies Quarterly, 38:193-218.

Arat, Z. F. (1991). Democracy and human rights in developing countries. Lynne Rienner, Boulder, CO. 
Axelrod, R. (1981). The Emergence of Cooperation among Egoists. American Political Science Review, 75:306-318.

Bäck, H. and Hadenius, A. (2008). Democracy and State Capacity: Exploring a J-Shaped Relationship. Governance, 21(1):1-24.

Bailey, D. and de Propris, L. (2004). A Bridge Too Phare? EU Pre-Accession Aid and Capacity-Building in the Candidate Countries. Journal of Common Market Studies, 42(1):77-98.

Bal, H. S. (2018). India's Embattled Democracy.

Bánkuti, M., Halmai, G., and Scheppele, K. L. (2012). Disabling the Constitution. Journal of Democracy, 23(3):138-146.

Beaulieu, E. and Hyde, S. (2009). In the Shadow of Democracy Promotion. Comparative Political Studies, 42(3):392-415.

Beissinger, M. R. (2007). Structure and Example in Modular Political Phenomena: The Diffusion of Bulldozer/Rose/Orange/Tulip Revolutions. Perspectives on Politics, 5(2):259-276.

Berman, S. (2016). The Lost Left. Journal of Democracy, 27(4):69-76.

Bermeo, N. (2016). On Democratic Backsliding. Journal of Democracy, 27(1):5-19.

Bideleux, R. (2001). 'Europeanisation' and the limits to democratisation in EastCentral Europe. In Pridham, G. and Ágh, A., editors, Prospects for democratic consolidation in East-Central Europe, chapter 2, pages 25-53. Manchester University Press, Manchester.

Bliss, H. and Russett, B. (1998). Democratic Trading Partners: The Liberal Connection. Journal of Politics, 60(4):1126-1147.

Blokker, P. (2013). New Democracies in Crisis? : A Comparative Constitutional Study of the Czech Republic, Hungary, Poland, Romania and Slovakia. Routledge.

Bobbio, N. (1988). Liberalism and Democracy. London, verso edition.

Boehmer, C., Gartzke, E., and Nordstrom, T. (2004). Do Intergovernmental Organizations Promote Peace? World Politics, 57(1):1-38.

Boix, C. (2003). Democracy and Redistribution. Cambridge University Press, Cambridge.

Boix, C. (2011). Democracy, Development, and the International System. American Political Science Review, 105(04):809-828. 
Bollen, K. A. and Paxton, P. (2000). Subjective measures of liberal democracy. Comparative Political Studies, 33:58-86.

Bowman, K., Lehoucq, F., and Mahoney, J. (2005). Measuring political democracy: case expertise, data adequacy, and Central America. Comparative Political Studies, 38:939-970.

Brooks, S. M. and Kurtz, M. J. (2016). Oil and Democracy: Endogenous Natural Resources and the Political "Resource Curse". International Organization, 70(2):279-311.

Bugaric, B. (2008). Populism, liberal democracy, and the rule of law in Central and Eastern Europe. Communist and Post-Communist Studies, 41(2):191-203.

Bugaric, B. (2015). A crisis of constitutional democracy in post-Communist Europe: "Lands in-between" democracy and authoritarianism. International Journal of Constitutional Law, 13(1):219-245.

Burgoon, B. (2012). Partisan Embedding of Libearlism: How Trade, Investment, and Immigration Affect Party Support for the Welfare State. Comparative Political Studies, 45(5):606-635.

Burnell, P. J. and Schlumberger, O. (2010). Promoting democracy - promoting autocracy? International politics and national political regimes. Contemporary Politics, $16(1): 1-15$.

Bush, S. S. (2015). The Taming of Democracy Assistance: Why Democracy Promotion Does Not Confront Dictators. Cambridge University Press, Cambridge.

Bushway, S., Johnson, B. D., and Slocum, L. A. (2007). Is the Magic Still There? The Use of the Heckman Two-Step Correction for Selection Bias in Criminology. Journal of Quantitative Criminology, 23(2):151-178.

Byman, D. L. and Pollack, K. M. (2001). Let Us Now Praise Great Men: Bringing the Statesman Back In. International Security, 25(4):107-146.

Canovan, M. (1999). Trust the People! Populism and the Two Faces of Democracy. Political Studies, 47:2-16.

Cao, X. (2009). Networks of intergovernmental organizations and convergence in domestic economic policies. International Studies Quarterly, 53(4):1095-1130.

Carothers, T. (2002). The End of the Transition Paradigm. Journal of Democracy, 13(1):5-21.

Carothers, T. (2006). Confronting the Weakest Link: Aiding Political Parties in New Democracies. Carnegie Endowment for International Peace, Washington, DC. 
Cerny, P. G. (1994). The Dynamics of Financial Globalization: Technology, Market Structure, and Policy Response. Policy Sciences, 27(4):319-342.

Checkel, J. T. (2005). International Institutions and Socialization in Europe: Introduction and Framework. International Organization, 59(4):801-826.

Clark, T. S. and Linzer, D. A. (2015). Should I Use Fixed or Random Effects? Political Science Research and Methods, 3(2):399-408.

Collier, D. and Levitsky, S. (1997). Democracy with Adjectives: Conceptual Innovation in Comparative Research. World Politics, 49(3):430-451.

Cooper, A. and Legler, T. (2006). Intervention Without Intervening? The OAS Defense and Promotion of Democracy in the Americas. Palgrave Macmillan, New York.

Coppedge, M., Gerring, J., Lindberg, S. I., Skaaning, S.-E., Teorell, J., Altman, D., Andersson, F., Bernhard, M., Fish, M. S., Glynn, A., Hicken, A., Knutsen, C. H., Marquardt, K. L., McMann, K., Mechkova, V., Paxton, P., Pemstein, D., Saxer, L., Seim, B., Sigman, R., and Staton, J. (2018). V-Dem Codebook v8.

Coppedge, M. and Reinicke, W. H. (1991). Measuring polyarchy. In Alex Inkeles, editor, On measuring democracy: Its consequences and concomitants, pages 47-68. Transaction, New Brunswick, NJ.

Correlates of War Project (2016). State System Membership List, v2016.

Crawford, G. (2001). Foreign Aid and Political Reform : A Comparative Analysis of Democracy Assistance and Political Conditionality. Palgrave, New York.

Cruz, C., Kefer, P., and Scartascini, C. (2016). Database of Political Institutions Codebook, 2015 Update (DPI2015).

Dahl, R. (1971). Polyarchy: Participation and Opposition. Yale University Press, New Haven.

Dawson, J. and Hanley, S. (2016). The Fading Mirage of the "Liberal Consensus". Journal of Democracy, 27(1):20-34.

Diamond, L. (2008). The Democratic Rollback: The Resurgence of the Predatory State. Foreign Affairs, 87(2):36-48.

Diamond, L. and Plattner, M., editors (2015). Democracy in Decline? Johns Hopkins University Press, Baltimore. 
Diamond, L., Plattner, M. F., and Schedler, A. (1999). Introduction. In Schedler, A., Diamond, L., and Plattner, M. F., editors, The Self-Restraining State: Power and Accountability in New Democracies, chapter 1, pages 1-10. Lynne Rienner, Boulder, CO.

Diamond, L. J. (2002). Thinking About Hybrid Regimes. Journal of Democracy, $13(2): 21-35$.

Dimitrova, A. (2002). Enlargement, Institution-Building and the EU's Administrative Capacity Requirement. West European Politics, 25(4):171-190.

Dimitrova, A. and Pridham, G. (2004). International actors and democracy promotion in central and eastern Europe: the integration model and its limits. Democratization, 11(5):91-112.

Dinan, D. (2005). Ever Closer Union: An Introduction to European Integration. Lynne Rienner, Boulder, CO, 3rd edition.

Dix, R. H. (1992). Democratization and the Institutionalization of Latin American Political Parties. Comparative Political Studies, 24(4):488-511.

Donno, D. (2013a). Defending Democratic Norms: International Actors and the Politics of Electoral Misconduct. Oxford University Press, Oxford.

Donno, D. (2013b). Elections and Democratization in Authoritarian Regimes. American Journal of Political Science, 57(3):703-716.

Dreher, A. and Voigt, S. (2011). Does membership in international organizations increase governments' credibility? Testing the effects of delegating powers. Journal of Comparative Economics, 39(3):326-348.

Ekiert, G. (2008). Dilemmas of Europeanization : Eastern and Central Europe after the EU Enlargement. Acta Slavica Iaponica, 25:1-28.

Ereli, A. (2018). The Teetering Czech Journey in Europe.

Eubank, N. (2012). Taxation, Political Accountability and Foreign Aid: Lessons from Somaliland. Journal of Development Studies, 48(4):465-480.

European Commission (1999). 1999 Regular Report from the Commission on Hungary's Progress towards Accession.

European Commission (2000). 2000 Regular Report from the Commission on Hungary's Progress towards Accession.

European Commission (2002a). Regular Report from the Commission on Hungary's Progress towards Accession: 1999, 2000, 2001, and 2002. 
European Commission (2002b). Regular Report from the Commission on Poland's Progress toward Accession: 1999, 2000, 2001, 2002.

Fearon, J. D. (2003). Ethnic and Cultural Diversity by Country. Journal of Economic Growth, 8(2):195-222.

Feenstra, R. C., Inklaar, R., and Timmer, M. P. (2015). The Next Generation of the Penn World Table. American Economic Review, 105(10):3150-3182.

Fink-Hafner, D. (2007). Europeanization in managing EU affairs: Between divergence and convergence, a comparative study of Estonia, Hungary and Slovenia. Public Administration, 85(3):805-828.

Finkel, E. and Brudny, Y. M. (2012). Russia and the colour revolutions. Democratization, 19(1):15-36.

Finnemore, M. (1993). International Organizations as Teachers of Norms: The United Nations Educational, Scientific, and Cultural Organization and Science Policy. International Organization, 47(4):565-597.

Fish, M. S. (2001). The Dynamics of Democratic Erosion. In Anderson, R., Fish, M., Hanson, S., and Roeder, P., editors, Postcommunism and the Theory of Democracy, pages 54-95. Princeton University Press, Princeton.

Fish, M. S. (2006). Stronger Legislatures, Stronger Democracies. Journal of Democracy, 17(1):5-20.

Flores, T. and Nooruddin, I. (2016). Elections in Hard Times: Building Stronger Democracies in the 21st Century. Cambridge University Press, Cambridge.

Foa, R. S. and Mounk, Y. (2017). The Signs of Deconsolidation. Journal of Democracy, 28(1).

Follesdal, A. and Hix, S. (2006). Why There is a Democratic Deficit in the EU: A Response to Majone and Moravcsik. Journal of Common Market Studies, 44(3):533562.

Fomina, J. and Kucharczyk, J. (2016). Populism and Protest in Poland. Journal of Democracy, 27(4):58-68.

Fortin, J. (2012). Is There a Necessary Condition for Democracy? The Role of State Capacity in Postcommunist Countries. Comparative Political Studies, 45(7):903930.

Frank, D. J. (1997). Science, Nature, and the Globalization of the Environment, 1870-1990. Social Forces, 76(2):409-435.

Freedom House (2007). Freedom in the World. 
Freedom House (2016). Freedom in the World.

Fukuyama, F. (1989). The End of History? The National Interest.

Gartzke, E., Nordstrom, T., and Boehmer, C. (2012). Disaggregating IGOs in Time and Space.

Gasiorowski, M. J. (1996). An overview of the political regime change data set. Compartive Political Studies, 29:469=483.

Geddes, B. (1990). How the Cases You Choose Affect the Answers You Get: Selection Bias in Comparative Politics. Political Analysis, pages 131-150.

Geddes, B., Wright, J., and Frantz, E. (2014). Autocratic Breakdown and Regime Transitions: A New Data Set. Perspectives on Politics, 12(2):313-331.

Geissel, B., Kneuer, M., and Lauth, H.-J. (2016). Measuring the quality of democracy: Introduction. International Political Science Review, 37(5):571-579.

Gelman, A. and Hill, J. (2007). Data Analysis Using Regression and Multilevel/Hierarchical Models. Cambridge University Press, Cambridge.

Genna, G. M. and Hiroi, T. (2014). Regional Integration and Democratic Conditionality: How Democracy Clauses Help Democratic Consolidation and Deepening. Routledge, Florence, GB.

Gerring, J. (2007). Case Study Research: Principles and Practices. Cambridge University Press, Cambridge.

Gibler, D. M. and Randazzo, K. A. (2011). Testing the Effects of Independent Judiciaries on the Likelihood of Democratic Backsliding. American Journal of Political Science, 55(3):696-709.

Gleditsch, K. S. and Ward, M. D. (2006). Diffusion and the International Context of Democratization. International Organization, 60(4):911-933.

Gleditsch, N. P., Wallensteen, P., Eriksson, M., Sollenberg, M., and Strand, H. (2002). Armed Conflict 1946-2001: A New Dataset. Journal of Peace Research, 39(5):615637.

Grabbe, H. (2001). How does Europeanization affect CEE governance? Conditionality, diffusion and diversity. Journal of European Public Policy, 8(6):1013-1031.

Grabbe, H. (2014). Six Lessons of Enlargement Ten Years On: The EU's Transformative Power in Retrospect and Prospect. JCMS: Journal of Common Market Studies, 52:40-56. 
Graham, B. A. T., Miller, M., and Strøm, K. (2017). Safeguarding Democracy: Powersharing and Democratic Survival. American Political Science Review, pages $1-19$.

Graham, G. (1992). Liberalism and Democracy. Journal of Applied Philosophy, 9(2):149-160.

Gray, J. (2009). International Organization as a Seal of Approval: European Union Accession and Investor Risk. American Journal of Political Science, 53(4):931-949.

Grigorescu, A. (2003). International Organizations and Government Transparency: Linking the International and Domestic Realms. International Studies Quarterly, $47(4): 643-667$.

Grzymala-Busse, A. (2007). Rebuilding Leviathan: Party Competition and State Exploitation in Post-Communist Democracies. Cambridge University Press, Cambridge.

Grzymalaa-Busse, A. and Innes, A. (2003). Great Expectations: The EU and Domestic Political Competition in East Central Europe. East European Politics and Societies, 17(1):64-73.

Gunitsky, S. (2014). From shocks to waves: hegemonic transitions and democratization in the twentieth century. International Organization, 68(3):561-597.

Gwartney, J., Lawson, R. A., Hall, J. C., Murphy, R., Fike, R., Grant, R. J., McMahon, F., de Soysa, I., and Vadlamannati, K. C. (2017). Economic Freedom of the World: 2017 Annual Report.

Gyimah-Boadi, E. (2015). Africa's Waning Democratic Commitment. Journal of Democracy, 26(1):101-113.

Hadenius, A. (1992). Democracy and development. Cambridge University Press, Cambridge.

Hadenius, A. and Teorell, J. (2007). Pathways from Authoritarianism. Journal of Democracy, 18(1):143-157.

Haggard, S. and Kaufman, R. R. (2012). Inequality and Regime Change: Democratic Transitions and the Stability of Democratic Rule. American Political Science Review, 106(03):495-516.

Haggard, S. and Kaufman, R. R. (2016). Democratization During the Third Wave. Annual Review of Political Sciencel, 19(8):1-20.

Haggard, S. and Maxfield, S. (1996). The Political Economy of Financial Internationalization in the Developing World. International Organization, 50(1):35-68. 
Hanley, S. and Sikk, A. (2016). Economy, corruption or floating voters? Explaining the breakthroughs of anti-establishment reform parties in eastern Europe. Party Politics, 22(4):522-533.

Heckman, J. J. (1979). Sample Selection Bias as a Specification Error. Econometrica, 47(1):153-161.

Hegre, H. (2014). Democracy and armed conflict. Journal of Peace Research, $51(2): 159-172$.

Hellwig, T. (2014). Balancing Demands: The World Economy and the Composition of Policy Preferences. The Journal of Politics, 76(1):1-14.

Henderson, S. (2003). Building Democracy in Contemporary Russia: Western Support for Grassroots Organizations. Cornell University Press, Ithaca.

Herman, L. E. (2015). Re-evaluating the post-communist success story: party elite loyalty, citizen mobilization and the erosion of Hungarian democracy. European Political Science Review, pages 1-34.

Hernandez, E. and Kriesi, H. (2016). The political consequences of the financial and economic crisis in Europe. European Journal of Political Research, 55:203-224.

Hix, S., Noury, A. G., and Roland, G. (2007). Democratic Politics in the European Parliament. Cambridge University Press, Cambridge.

Howard, M. M. and Roessler, P. G. (2006). Liberalizing Electoral Outcomes in Competitive Authoritarian Regimes. American Journal of Political Science, 50(2):365381.

Human Rights Watch (2010). Human Rights Watch: World Report 2010. Technical report, New York.

Human Rights Watch (2013). Human Rights Watch: World Report 2013. Technical report, New York.

Huntington, S. P. (1968). Political Order in Changing Societies. Yale University Press, New Haven.

Huntington, S. P. (1991). The Third Wave: Democratization in the Late Twentieth Century. University of Oklahoma Press, Norman.

Hyde, S. D. (2011). The Pseudo-Democrat's Dilemma: Why Election Observation Became An International Norm. Cornell University Press, Ithaca.

Inglehart, R. and Welzel, C. (2005). Modernization, Cultural Change, and Democracy: The Human Development Sequence. Cambridge University Press, Cambridge. 
Ingram, P., Robinson, J., and Busch, M. L. (2005). The Intergovernmental Network of World Trade: IGO Connectedness, Governance, and Embeddedness. American Journal of Sociology, 111(3):824-858.

Innes, A. (2002). Party Competition in Postcommunist Europe: The Great Electoral Lottery. Comparative Politics, 35(1):85-104.

Innes, A. (2014). The Political Economy of State Capture in Central Europe. Journal of Common Market Studies, 52(1):88-104.

Issacharoff, S. (2015). Fragile Democracies: Contested Power in the Era of Constitutional Courts. Cambridge University Press, Cambridge.

Jablonski, R. S. (2014). How Aid Targets Votes: The Impact of Electoral Incentives on Foreign Aid Distribution. World Politics, 66(2):293-330.

Jenne, E. K. and Mudde, C. (2012). Can Outsiders Help? Journal of Democracy, 23(3):147-155.

Johnson, V. E. and Albert, J. H. (1999). Ordinal Data Modeling. Springer, New York.

Johnstone, I. and Snyder, M. (2016). Democracy Promotion. In Cogan, J. K., Hurd, I., and Johnstone, I., editors, The Oxford Handbook of International Organizations, chapter 24, pages 508-534. Oxford University Press, Oxford.

Kapstein, E. B. and Converse, N. (2008). Why Democracies Fail. Journal of Democracy, 19(4):57-68.

Katsanidou, A. and Otjes, S. (2015). How the European debt crisis reshaped national political space: The case of Greece. European Union Politics, 17(2):262-284.

Kelemen, R. D. (2017). Europe's Other Democratic Deficit: National Authoritarianism in a Democratic Union. Government and Opposition, 52(2):211-238.

Kelemen, R. D. and Orenstein, M. A. (2016). Europe's Autocracy Problem: Polish Democracy's Final Days? Foreign Affairs.

Kelley, J. (2004). International Actors on the Domestic Scene: Membership Conditionality and Socialization by International Institutions. International Organization, 58(03).

Keohane, R. O. (1984). After Hegemony: Cooperation and Discord in the World Political Economy. Princeton University Press, Princeton.

King, G., Keohane, R. O., and Verba, S. (1994). Designing Social Inquiry. Princeton University Press, Princeton. 
Kitschelt, H., Manfeldova, Z., Markowski, R., and Toka, G. (1999). Post-Communist Party Systems. Cambridge University Press, Cambridge.

Kollman, K., Hicken, A., Caramani, D., Backer, D., and Lublin, D. (2016). Constituency-level elections archive. Technical report, Center for Political Studies, University of Michigan, Ann Arbor, MI.

Koremenos, B., Lipson, C., and Snidal, D. (2001). The Rational Design of International Institutions. International Organization, 761-799.

Krastev, I. (2016). The Unraveling of the Post-1989 Order. Journal of Democracy, $27(4): 88-98$.

Ladrech, R. (2008). Europeanization and the variable influence of the EU: national parties and party systems in Western and Eastern Europe. Journal of Southern Europe and the Balkans, 10(2):139-150.

Levitsky, S. and Way, L. (2002). The Rise of Competitive Authoritarianism. Journal of Democracy, 13(2):51-65.

Levitsky, S. and Way, L. (2015). The Myth of Democratic Recession. Journal of Democracy, 26(1):45-58.

Levitsky, S. and Way, L. A. (2010). Competitive Authoritarianism: Hybrid Regimes After the Cold War. Cambridge University Press, Cambridge.

Levitz, P. and Pop-Eleches, G. (2010). Why No Backsliding? The European Union's Impact on Democracy and Governance Before and After Accession. Comparative Political Studies, 43:457-485.

Lijphart, A. (1971). Comparative Politics and the Comparative Method. American Political Science Review, 65(3):682-693.

Lijphart, A. (1977). Democracy in Plural Societies: A Comparative Exploration. Yale University Press, New Haven.

Linden, R. H. (2008). The New Populism in Central and Southeastern Europe. Problems of Post-Communism, 55(3):3-6.

Linz, J. and Stepan, A. (1996). Problems of Democratic Transition and Consolidation: Southern Europe, South America, and Post-Communist Europe. Johns Hopkins University Press, Baltimore.

Linz, J. J. (1990). The Perils of Presidentialism. Journal of Democracy.

Lipset, S. M. (1959). Some Social Requisites of Democracy : Economic Development and Political Legitimacy. The American Economic Review, 53(1):69-105. 
Lipset, S. M. and Rokkan, S. (1967). Cleavage Structures, Party Systems, and Voter Alignments: An Introduction. In Party Systems and Voter Alignments: CrossNational Perspectives, chapter 1, pages 1-64. The Free Press, New York.

Lochocki, T. (2016). Will the German Center Hold? Journal of Democracy, 27(4):3746.

Luhrmann, A., Marquardt, K. L., and Mechkova, V. (2017). Constraining Governments: New Indices of Vertical, Horizontal and Diagonal Accountability.

Maeda, K. (2010). Two Modes of Democratic Breakdown: A Competing Risks Analysis of Democratic Durability. The Journal of Politics, 72(4):1129-1143.

Magone, J. M. (2004). Breaking with the authoritarian past in Portugal: continuities and discontinuities of international linkages and their impact on the political system. Portuguese Journal of Social Science, 3(3):157-174.

Mahoney, J. (2000). Strategies of Causal Inference in Small-N Analysis. Sociological Methods \& Research, 28(4):387-424.

Mainwaring, S. (1998). Party Systems in the Third Wave. Journal of Democracy, $9(3): 67-81$.

Mainwaring, S. and Pérez-Liñán, A. (2013). Democratic Breakdown and Survival. Journal of Democracy, 24(2):123-137.

Mainwaring, S. and Scully, T. R. (1995). Introduction: Party Systems in Latin America. In Mainwaring, S. and Scully, T., editors, Building Democratic Institutions: Party Systems in Latin America, pages 1-34. Stanford University Press, Stanford.

Mainwaring, S. P. (1999). Rethinking Party Systems in the Third Wave of Democratization: The Case of Brazil. Stanford University Press, Stanford.

Mair, P. (2007). Political parties and party systems. In Europeanization: New research agendas. Palgrave Macmillan, Hampshire, England.

Mansfield, E. D., Milner, H. V., and Rosendorff, B. P. (2000). Free to Trade: Democracies, Autocracies, and International Trade. American Political Science Review, 94(2):305-321.

Mansfield, E. D., Milner, H. V., and Rosendorff, B. P. (2002). Why Democracies Cooperate more: Electoral Control and International Trade Agreements. International Organization, 56(3):447-513.

Mansfield, E. D. and Pevehouse, J. C. (2006). Democratization and the Varieties of International Organizations. International Organization, 60(1):137-167. 
Mansfield, E. D. and Pevehouse, J. C. (2008). Democratization and the Varieties of International Organizations. Journal of Conflict Resolution, 52(2):269-294.

Marquez, X. (2016). A Quick Method for Extending the Unified Democracy Scores. SSRN Electronic Journal, pages 1-33.

Marquez, X. (2017). QuickUDS: Extend the Unified Democracy Scores Backwards and Forwards in Time easily. R package version 0.1.6.

Marshall, M. G., Gurr, T. R., and Jaggers, K. (2016). Polity IV Project: Political Regime Characteristics and Transitions, 1800-2010. Data Users' Manual. Technical report, Center for Systemic Peace, College Park: University of Maryland.

Mayne, Q. and Geissel, B. (2016). Putting the demos back into the concept of democratic quality. International Political Science Review, 37(5):634-644.

Merkel, W. (2010). Are dictatorships returning? Revisiting the 'democratic rollback' hypothesis. Contemporary Politics, 16(1):17-31.

Meyer, J. W., Ramirez, F. O., and Soysal, Y. N. (1992). World Expansion of Mass Education. Sociology of Education, 65(2):192-149.

Mill, J. S. (1859). On Liberty. John W. Parker and Son, West Strand, London.

Minkenberg, M. (2002). The Radical Right in Postsocialist Central and Eastern Europe: Comparative Observations and Interpretations. East European Politics 8 Societies, 16(2):335-362.

Mishra, R. (1999). Globalization and the Welfare State. Edward Elgar, Cheltenham.

Moon, B. E., Birdsall, J. H., Ciesluk, S., Garlett, L. M., Hermias, J. J., Mendenhall, E., Schmid, P. D., and Wong, W. H. (2006). Voting Counts: Participation in the Measurement of Democracy. Studies in Comparative International Development, $41(2): 3-32$.

Moore, B. (1966). Social Origins of Dictatorship and Democracy: Lord and Peasant in the Making of the Modern World. Beacon Press, Boston.

Moravcsik, A. (1994). Why the European Community Strengthens the State: Domestic Politics and International Cooperation.

Moravcsik, A. (1998). The choice for Europe: social purpose and state power from Messina to Masstricht. UCL Press, London.

Moravcsik, A. and Vachudova, M. A. (2003). National Interests, State Power, and EU Enlargement. Perspectives, 19:21-31. 
Morlino, L. (2011). Changes for Democracy: Actors, Structures, and Processes. Oxford University Press, Oxford.

Morrow, J. D. (1994). Modeling the Forms of International Cooperation: Distribution versus Information. International Organization, 48:387-423.

Morrow, J. D., Siverson, R. M., and Tabares, T. E. (1998). The Political Determinants of International Trade: The Major Powers, 1907-1990. American Political Science Review, 92(3):649-661.

Mosley, L. (2000). Room to Move: International Financial Markets and National Welfare States. International Organization, 54(4):737-773.

Mudde, C. (2007). Populist Radical Right Parties in Europe. Cambridge University Press, New York.

Muller, J.-W. (2013). Defending Democracy within the EU. Journal of Democracy, 24(2):138-149.

Nalepa, M. (2017). This is what the gradual erosion of rule of law looks like in Poland. The Washington Post: Monkey Cage.

Nanou, K. and Dorussen, H. (2013). European integration and electoral democracy: How the European Union constrains party competition in the Member States. European Journal of Political Research, 52:71-93.

Nardulli, P. F., Wong, C. J., Singh, A., Peyton, B., and Bajjalieh, J. (2012). The Composition of Religious and Ethnic Groups (CREG) Project.

Nikolenyi, C. (2014). Institutional Design and Party Government in Post-Communist Europe. Oxford University Press, Oxford.

Noutcheva, G. (2016). Societal Empowerment and Europeanization: Revisiting the EU's Impact on Democratization. Journal of Common Market Studies, 54(3):691708.

Nygard, H. M. (2017). The role of international organizations in regime transitions: How IGOs can tie a dictator's hands. Conflict Management and Peace Science, 34(4):406-430.

O’Donnell, G. (1994). Delegative Democracy. Journal of Democracy, 5(1):55-69.

O’Donnell, G. (1999). Horizontal Accountability in New Democracies. In Schedler, A., Diamond, L., and Plattner, M. F., editors, The Self-Restraining State: Power and Accountability in New Democracies, pages 27-51. Lynne Rienner, Boulder, CO. 
O'Donnell, G. and Schmitter, P. C. (1986). Transitions from Authoritarian Rule: Tentative Conclusions about Uncertain Democracies. The Johns Hopkins University Press, Baltimore.

Oneal, J. R. and Russett, B. (1999). The Kantian Peace: The Pacific Benefits of Democracy, Interdependence, and International Organizations, 1885-1992. World Politics, 52:1-37.

Ostrow, R. (2014). A Deterioration of Democracy?: Corruption, Transparency, and Apathy in the Western World. SAIS Review of International Affairs, 34(1):41-44.

Pahre, R. (1995). Wider and Deeper: The Links between Expansion and Integration in the European Union. In Schneider, G., Weitsman, P. A., and Bernauer, T., editors, Towards a New Europe: Stops and Starts in Regional Integration, chapter 6, pages 111-136. Praeger, London.

Palma, G. D. (1990). To Craft Democracies. University of California Press, Berkley.

Pappas, T. S. (2016). Distinguishing Liberal Democracy's Challengers. Journal of Democracy, 27(4):22-36.

Pastor, M. (1987). The International Monetary Fund and Latin America: Economic Stabilization and Class Conflict. Westview Press, Boulder.

Pemstein, D., Meserve, S. A., and Melton, J. (2010). Democratic compromise: A Latent Variable Analysis of Ten Measures of Regime Type. Political Analysis, 18(4):426-449.

Pevehouse, J. (2005). Democracy from above : regional organizations and democratization. Oxford University Press, Cambridge.

Pevehouse, J., Nordstrom, T., and Warnke, K. (2004). The Correlates of War 2 International Governmental Organizations Data Version 2.0. Conflict Management and Peace Science, 21(2):101-119.

Pevehouse, J. C., McManus, R., Nordstrom, T., Shannon, M., and Widmann, M. (2016). The COW-2 International Organizations Dataset Version 3.0.

Pierson, C. (1995). Dismantling the Welfare State? Reagan, Thatcher and the Politics of Retrenchment. Cambridge University Press, Cambridge.

Poast, P. and Urpelainen, J. (2015). How International Organizations Support Democratization: Preventing Authoritarian Reversals or Promoting Consolidation? World Politics, 67(01):72-113.

Poast, P. and Urpelainen, J. (2018). Organizing democracy: How international organizations assist new democracies. University of Chicago Press, Chicago. 
Polachek, S. W. (1997). Why Democracies Cooperate More and Fight Less: The Relationship betweeen International Trade and Cooperation. Review of Internaitonal Economics, 5(3):295-309.

Powell, C. (1996). International Aspects of Democratization: The Case of Spain. In Whitehead, L., editor, The International Dimensions of Democratization: Europe and the Americas, chapter 11, pages 285-314. Oxford University Press, Oxford.

Preston, C. (1995). Obstacles to EU Enlargement: The Classical Community Method and the Prospects for a Wider Europe. JCMS: Journal of Common Market Studies, $33(3): 451-463$.

Pridham, G. (1995). The International Context of Democratic Consolidation: Southern Europe in Comparative Perspective. In Gunther, R., Diamandouros, P., and Puhle, H.-J., editors, The Politics of Democratic Consolidation: Southern Europe in Comparative perspective, pages 166-203. Johns Hopkins University Press, Baltimore.

Pridham, G. (2007). Change and Continuity in the European Union's Political Conditionality: Aims, Approach, and Priorities. Democratization, 14(3):446-471.

Pridham, G. (2008). Status Quo Bias or Institutionalisation for Reversibility?: The EU's Political Conditionality, Post-Accession Tendencies and Democratic Consolidation in Slovakia. Europe-Asia Studies, 60(3):423-454.

Przeworski, A., Alvarez, M., Cheibub, J. A., and Limongi, F. (2000). Democracy and development: Political regimes and economic well-being in the World, 1950-1990. Cambridge University Press, Cambridge.

Przeworski, A. and Limongi, F. (1997). Modernization: Theories and Facts. World Politics, 49(2):155-183.

Putnam, R. D. (1993). Making Democracy Work: Civic Traditions in Modern Italy. Princeton University Press, Princeton.

Quaglia, L., Neuvonen, M., Miyakoshi, M., and Cini, M. (2007). Europeanization. In European Union Politics, chapter 25, pages 405-420. Oxford University Press, Oxford, 2nd edition.

Ragin, C. C. (1987). The Comparative Method: Moving Beyond Qualitative and Quantitative Strategies. University of California Press, Berkeley.

Raik, K. (2004). EU Accession of Central and Eastern European Countries: Democracy and Integration as Conflicting Logics. East European Politics and Societies, 18(4):567-594.

Rankin, J. (2018). How Hungarian PM's supporters profit from EU-backed projects. 
Rawls, J. (1993). Political Liberalism. Columbia University Press, New York.

Reiter, D. (2001). Why NATO Enlargement Does Not Spread Democracy. International Security, 25(4):41-67.

Reynié, D. (2016). "Heritage Populism" and France's National Front. Journal of Democracy, 27(4):47-57.

Ringen, S. (2018). Who in the world will defend democracy?

Roberts, K. M. (2007). Latin America's Populist Revival. SAIS Review of International Affairs, 17(1):3-15.

Rodrik, D. (1997). Has globalization gone too far? Institute for International Economics, Washington, DC.

Rose-Ackerman, S. (2005). From Elections to Democracy: Building Accountable Government in Hungary and Poland. Cambridge University Press, Cambridge.

Ross, F. (2000). Beyond Left and Right: The New Partisan Politics of Welfare. Governance, 13:155-183.

Ross, M. and Mahdavi, P. (2015). Oil and Gas Data, 1932-2014.

Ross, M. L. (2015). What Have We Learned about the Resource Curse? Annual Review of Political Science, 18:239-259.

Rupnik, J. (2007). Is East-Central Europe Backsliding? From Democracy Fatigue to Populist Backlash. Journal of Democracy, 18(4):17-25.

Rupnik, J. (2016). Surging Illiberalism in the East. Journal of Democracy, 27(4):7787.

Russett, B. (1993). Grasping the Democratic Peace. Princeton University Press, Princeton.

Russett, B. (1994). Grasping the Democratic Peace: Principles for a Post-Cold War World. Princeton University Press, Princeton.

Rustow, D. (1970). Transitions to Democracy: Toward a Dynamic Model. Comparative Politics, 2(3):337-363.

Sánchez-Cuenca, I. (2017). From a Deficit of Democracy to a Technocratic Order: The Postcrisis Debate on Europe. Annual Review of Political Science, 20(1).

Savage, J. D. (2017). Military Size and the Effectiveness of Democracy Assistance. Journal of Conflict Resolution, 61(4):839-868.

Schedler, A. (2002). The Menu of Manipulation. Journal of Democracy, 13(2):36-50. 
Schenkkan, N. (2017). Nations in Transit 2017: The False Promise of Populism. Technical report, Freedom House.

Schimmelfennig, F. (2005). Strategic Calculation and International Socialization: Membership Incentives, Party Constellations, and Sustained Compliance in Central and Eastern Europe. International Organization, 59(4):827-860.

Schmitter, P. C. and Karl, T. L. (1991). What Democracy Is...and Is Not. Journal of Democracy, 2(3):75-88.

Schultz, K. A. and Weingast, B. R. (2003). The Democratic Advantage: Institutional Foundations of Financial Power in International Competition. International Organization, 57.

Schumpeter, J. A. (1950). Capitalism, Socialism and Democracy. Harper, New York.

Seawright, J. and Gerring, J. (2008). Case Selection Techniques in Case Study Research: A Menu of Qualitative and Quantitative Options. Political Research Quarterly, 61(2):294-308.

Sedelmeier, U. (2014). Anchoring Democracy from Above? The European Union and Democratic Backsliding in Hungary and Romania after Accession. Journal of Common Market Studies, 52(1):105-121.

Serra, G. (2012). The Risk of Partyarchy and Democratic Backsliding : Mexico's 2007 Electoral Reform. Taiwan Journal of Democracy, 8(1):31-56.

Shanks, C., Jacobson, H. K., and Kaplan, J. H. (1996). Inertia and Change in the Constellation of International Governmental Organizations, 1981-1992. International Organization, 50(4):593-627.

Simmons, B. A., Dobbin, F., and Garrett, G. (2006). Introduction: The International Diffusion of Liberalism. International Organization, 60(4):781-810.

Simmons, B. A. and Elkins, Z. (2004). The Globalization of Liberalization: Policy Diffusion in the International Political Economy. The American Political Science Review, 98(1):171-189.

Simon, M. W. and Gartzke, E. (1996). Political System Similarity and the Choice of Allies: Do Democracies Flock Together, or Do Opposites Attract? Journal of Conflict Resolutionc, 40(4):617-635.

Simpser, A. and Donno, D. (2012). Can International Election Monitoring Harm Governance? The Journal of Politics, 74(02):501-513.

Siverson, R. M. and Emmons, J. (1991). Birds of a Feather: Democratic Political Systems and Alliance Choices in the Twentieth Century. Journal of Conflict Resolution, 35(2). 
Slater, D. (2013). Democratic Careening. World Politics, 65(04):729-763.

Smith, K. E. (2001). Western Actors and the Promotion of Democracy. In Zielonka, J. and Pravda, A., editors, Democratic Consolidation in Eastern Europe, Volume II, chapter 1, pages 31-57. Oxford University Press, Oxford.

Spendzharova, A. B. and Vachudova, M. A. (2012). Catching Up? Consolidating Liberal Democracy in Bulgaria and Romania after EU Accession. West European Politics, 35(1):39-58.

Stepan, A. and Skach, C. (1993). Constitutional Frameworks and Democratic Consolidation: Parliamentarianism versus Presidentialism. World Politics, 46(1):1-22.

Stone, R. W. (2011). Controlling Institutions: International Organizations and the Global Economy. Cambridge University Press, Cambridge.

Sullivan, K. (2019). 'Losing support by the hour': Venezuela's Maduro will be out of power soon, Colombian president says.

Svolik, M. (2008). Authoritarian Reversals and Democratic Consolidation. American Political Science Review, 102(02):153-168.

Tallberg, J. (2008). Bargaining Power in the European Council. JCMS: Journal of Common Market Studies, 46(3):685-708.

Tavits, M. (2013). Post-Communist Democracies and Party Organization. Cambridge University Press, Cambridge.

Teorell, J. (2010). Determinants of democratization : explaining regime change in the world, 1972-2006. Cambridge University Press, Cambridge.

Tolstrup, J. (2013). When can external actors influence democratization? Leverage, linkages, and gatekeeper elites. Democratization, 20(4):716-742.

Treier, S. and Jackman, S. (2008). Democracy as a Latent Variable. American Journal of Political Science, 52(1):201-217.

Ugur, M. (2013). Europeanization, EU Conditionality, and Governance Quality: Empirical Evidence on Central and Eastern European Countries. International Studies Quarterly, 57:41-51.

Ulfelder, J. (2008). International Integration and Democratization: An Event History Analysis. Democratization, 15(2):272-296.

Vachudova, M. A. (2005). Europe Undivided: Democracy, Leverage, and Integration after Communism. Oxford University Press, Oxford. 
Vachudova, M. A. (2008). Tempered by the EU? Political parties and party systems before and after accession. Journal of European Public Policy, 15(6):861-879.

Van De Walle, N. (2003). Presidentialism and Clientelism in Africa's Emerging Party Systems. Journal of Modern African Studies, 41(2):297-321.

Vanhanen, T. (2003). Democratization: A comparative analysis of 170 countries. Routledge, New York.

Varga, M. and Freyberg-Inan, A. (2012). The Threat of Selective Democracy: Popular Dissatisfaction and Exclusionary Strategy of Elites in East Central and Southeastern Europe. Southeastern Europe, 36:349-372.

Vasilopoulou, S., Halikiopoulou, D., and Exadaktylos, T. (2014). Greece in Crisis: Austerity, Populism and the Politics of Blame. Journal of Common Market Studies, 52(2):388-402.

Volkens, A., Lehmann, P., Matthieß, T., Merz, N., Regel, S., and Bernhard, W. (2017). The Manifest Data Collect. Manifesto Project (MRG / CMP / MARPOR). Version 2017b. Technical report, Wissenschaftszentrum Berlin fur Sozialforschung (WZB), Berlin.

von Borzyskowski, I. and Vabulas, F. (2018). Credible Commitments? Explaining IGO Suspensions to Sanction Political Backsliding. International Studies Quarterly, (Forthcoming).

Waldner, D. and Lust, E. (2018). Unwelcome Change: Coming to Terms with Democratic Backsliding. Annual Review of Political Science, 21(5):1-21.

Ward, D., Kim, J. H., Graham, M., and Tavits, M. (2015). How Economic Integration Affects Party Issue Emphases. Comparative Political Studies, 48(10):1227-1259.

Watch, H. R. (2019). World Report 2019. Technical report, Human Rights Watch, New York.

Wedel, J. R. (2001). Collision and Collusion: The Strange Case of Western Aid to Eastern Europe. Palgrave, New York.

Whitehead, L. (1991). Democracy by convergence and Southern Europe: a comparative politics perspective. In Pridham, G., editor, Encouraging Democracy: The International Context of Regime Transition in Southern Europe, pages 45-61. St. Martin's Press, New York.

Whitehead, L. (1996). Concerning International Support for Democracy in the South. In Luckham, R. and White, G., editors, Democratization in the South: The Jagged Wave, pages 243-273. Manchester University Press, Manchester. 
Whitehead, L. (2015). Antidemocracy Promotion: Four Strategies in Search of a Framework. Taiwan Journal of Democracy, 10(2):1-24.

World Bank (2017). World Development Indicators 2017.

Yilmaz, H. (2002). External-Internal Linkages in Democratization: Developing an Open Model of Democratic Change. Democratization, 9(2):67-84.

Zakaria, F. (1997). The Rise of Illiberal Democracy. Foreign Affairs, 76(6):22-43.

Ziblatt, D. and Levitsky, S. (2018). How Democracies Die. Crown, New York. 


\section{Appendix A: Appendix to Chapter 4}

\section{A.1 Number of IO Memberships and Democratic Backsliding: Multilevel Models with Varying Intercepts by Country or Region}

The results reported in Table 4.4 are robust to models that include, first only varying intercepts by country, and then only varying intercepts by region. The results of these models can be found in Tables A.1 and A.2. 
Table A.1: Number of IO Memberships and Democratic Backsliding: Varying Intercepts by Country

\begin{tabular}{lccccc}
\hline & Demo IO & Non-Univ Demo IO & Pol/Econ IO & Demo Pol/Econ IO & Interven IO \\
\hline Num. IO memberships 5 years prior & $-0.16^{* * *}$ & $-0.11^{* * *}$ & $-0.17^{* * *}$ & $-0.11^{* * *}$ & $-0.24^{* * *}$ \\
& $(0.03)$ & $(0.02)$ & $(0.04)$ & $(0.02)$ & $(0.05)$ \\
GDP pc (log) & $0.56^{* * *}$ & $0.54^{* * *}$ & $0.51^{* * *}$ & $0.52^{* * *}$ & $0.49^{* * *}$ \\
& $(0.05)$ & $(0.05)$ & $(0.05)$ & $(0.05)$ & $(0.05)$ \\
GDP growth pc & $-0.04^{* *}$ & $-0.04^{* *}$ & $-0.04^{* *}$ & $-0.04^{* *}$ & $-0.04^{* *}$ \\
& $(0.01)$ & $(0.01)$ & $(0.01)$ & $(0.01)$ & $(0.01)$ \\
DIS index & $-1.94^{* * *}$ & $-1.94^{* * *}$ & $-1.94^{* * *}$ & $-1.95^{* * *}$ & $-1.94^{* * *}$ \\
& $(0.03)$ & $(0.03)$ & $(0.03)$ & $(0.03)$ & $(0.03)$ \\
Effec. num. parties (log) & 0.01 & 0.01 & 0.01 & 0.01 & 0.01 \\
State age (log) & $(0.02)$ & $(0.02)$ & $(0.02)$ & $(0.02)$ & $(0.02)$ \\
& -0.00 & -0.01 & -0.01 & -0.01 & -0.01 \\
Internal conflict & $(0.03)$ & $(0.03)$ & $(0.03)$ & $(0.03)$ & $(0.03)$ \\
& -0.01 & -0.00 & 0.00 & -0.00 & 0.01 \\
Oil income pc & $(0.01)$ & $(0.01)$ & $(0.01)$ & $(0.01)$ & $(0.01)$ \\
& $0.95^{* * *}$ & $0.94^{* * *}$ & $0.85^{* * *}$ & $0.96^{* * *}$ & $0.82^{* * *}$ \\
Ethnic frac. & $(0.16)$ & $(0.16)$ & $(0.17)$ & $(0.17)$ & $(0.17)$ \\
& $-0.27^{*}$ & $-0.27^{*}$ & $-0.30^{* *}$ & $-0.29^{* *}$ & $-0.33^{* *}$ \\
Mean region DIS change & $(0.11)$ & $(0.11)$ & $(0.11)$ & $(0.11)$ & $(0.11)$ \\
& -0.02 & -0.02 & -0.00 & -0.01 & 0.00 \\
Lagged DV & $(0.01)$ & $(0.01)$ & $(0.01)$ & $(0.01)$ & $(0.01)$ \\
& $-0.04^{* * *}$ & $-0.04^{* * *}$ & $-0.04^{* * *}$ & $-0.03^{* * *}$ & $-0.04^{* * *}$ \\
\hline AIC & $(0.01)$ & $(0.01)$ & $(0.01)$ & $(0.01)$ & $(0.01)$ \\
BIC & 1109.35 & 1110.87 & 1124.12 & 1119.05 & 1120.08 \\
Log. lik. & 1181.75 & 1183.27 & 1196.52 & 1191.46 & 1192.48 \\
Observations & -540.67 & -541.43 & -548.06 & -545.53 & -546.04 \\
Num. countries & 1302 & 1302 & 1302 & 1302 & 1302 \\
Variance: countries & 70 & 70 & 70 & 70 & 70 \\
Variance: residual & 0.92 & 0.92 & 0.93 & 0.94 & 0.95 \\
\hline
\end{tabular}

Note: Dependent variable: 5 -year change in DIS index. ${ }^{* * *} p<0.001,{ }^{* *} p<0.01,{ }^{*} p<0.05$ 
Table A.2: Number of IO Memberships and Democratic Backsliding: Varying Intercepts by Region

\begin{tabular}{lccccc}
\hline & Demo IO & Non-Univ Demo IO & Pol/Econ IO & Demo Pol/Econ IO & Interven IO \\
\hline Num. IO memberships 5 years prior & $-0.17^{* * *}$ & $-0.20^{* * *}$ & $-0.19^{* * *}$ & $-0.16^{* * *}$ & 0.01 \\
& $(0.03)$ & $(0.03)$ & $(0.05)$ & $(0.03)$ & $(0.05)$ \\
GDP pc (log) & $0.48^{* * *}$ & $0.48^{* * *}$ & $0.50^{* * *}$ & $0.48^{* * *}$ & $0.49^{* * *}$ \\
& $(0.04)$ & $(0.04)$ & $(0.04)$ & $(0.04)$ & $(0.04)$ \\
GDP growth pc & -0.05 & -0.05 & -0.05 & -0.05 & $-0.05^{*}$ \\
& $(0.03)$ & $(0.03)$ & $(0.03)$ & $(0.03)$ & $(0.03)$ \\
DIS index & $-1.13^{* * *}$ & $-1.13^{* * *}$ & $-1.14^{* * *}$ & $-1.13^{* * *}$ & $-1.16^{* * *}$ \\
& $(0.04)$ & $(0.04)$ & $(0.04)$ & $(0.04)$ & $(0.04)$ \\
Effec. num. parties (log) & $0.08^{* * *}$ & $0.08^{* * *}$ & $0.08^{* * *}$ & $0.08^{* * *}$ & $0.09^{* * *}$ \\
& $(0.02)$ & $(0.02)$ & $(0.02)$ & $(0.02)$ & $(0.02)$ \\
State age (log) & 0.03 & 0.03 & 0.04 & 0.03 & -0.01 \\
& $(0.03)$ & $(0.03)$ & $(0.03)$ & $(0.03)$ & $(0.04)$ \\
Internal conflict & $-0.08^{* * *}$ & $-0.09^{* * *}$ & $-0.07^{* * *}$ & $-0.09^{* * *}$ & $-0.07^{* * *}$ \\
& $(0.02)$ & $(0.02)$ & $(0.02)$ & $(0.02)$ & $(0.02)$ \\
Oil income pc & $-1.40^{* * *}$ & $-1.43^{* * *}$ & $-1.41^{* * *}$ & $-1.38^{* * *}$ & $-1.38^{* * *}$ \\
& $(0.17)$ & $(0.17)$ & $(0.18)$ & $(0.17)$ & $(0.18)$ \\
Ethnic frac. & 0.02 & 0.02 & 0.02 & 0.02 & 0.01 \\
& $(0.02)$ & $(0.02)$ & $(0.02)$ & $(0.02)$ & $(0.02)$ \\
Mean region DIS change & $0.14^{* * *}$ & $0.10^{* * *}$ & $0.16^{* * *}$ & $0.13^{* * *}$ & $0.20^{* * *}$ \\
Lagged DV & $(0.03)$ & $(0.03)$ & $(0.02)$ & $(0.03)$ & $(0.02)$ \\
& -0.01 & -0.02 & -0.01 & -0.01 & 0.01 \\
AIC & $(0.02)$ & $(0.02)$ & $(0.02)$ & $(0.02)$ & $(0.02)$ \\
BIC & 2545.11 & 2517.86 & 2555.11 & 2540.70 & 2571.57 \\
Log. lik. & 2617.51 & 2590.26 & 2627.51 & 2613.10 & 2643.97 \\
Observations & -1258.56 & -1244.93 & -1263.55 & -1256.35 & -1271.78 \\
Num. regions & 1302 & 1302 & 1302 & 1302 & 1302 \\
Variance: regions & 15 & 15 & 15 & 15 & 15 \\
Variance: residual & 0.10 & 0.12 & 0.12 & 0.11 & 0.09 \\
\hline
\end{tabular}

Note: Dependent variable: 5 -year change in DIS index. ${ }^{* * *} p<0.001,{ }^{* *} p<0.01,{ }^{*} p<0.05$ 


\section{A.2 Number of IO Memberships and Democratic Backsliding: Country and Year Fixed Effects}

I re-estimate the models from Table 4.4 using fixed effects models, the standard alternative to varying intercept models. Specifically, I estimate a series of OLS models

with fixed effects by country and year. The results of these models are largely similar to those in Table 4.4 and can be found in Table A.3. 
Table A.3: Number of IO Memberships and Democratic Backsliding, Country and Year Fixed Effects

\begin{tabular}{|c|c|c|c|c|c|}
\hline & \multicolumn{5}{|c|}{ Dependent variable: } \\
\hline & \multicolumn{5}{|c|}{ 5-Year Change in DIS Index } \\
\hline & Demo IO & Non-Univ Demo IO & $\mathrm{Pol} /$ Econ IO & Demo Pol/Econ IO & Interven IO \\
\hline Num. IO memberships 5 years prior & $\begin{array}{c}-0.17^{* * *} \\
(0.04)\end{array}$ & $\begin{array}{c}-0.12^{* * *} \\
(0.03)\end{array}$ & $\begin{array}{c}-0.20^{* * *} \\
(0.06)\end{array}$ & $\begin{array}{c}-0.10^{* * *} \\
(0.03)\end{array}$ & $\begin{array}{c}-0.36^{* * *} \\
(0.07)\end{array}$ \\
\hline GDP pc (log) & $\begin{array}{c}0.63^{* * *} \\
(0.07)\end{array}$ & $\begin{array}{c}0.60^{* * *} \\
(0.07)\end{array}$ & $\begin{array}{c}0.62^{* * *} \\
(0.07)\end{array}$ & $\begin{array}{c}0.61^{* * *} \\
(0.07)\end{array}$ & $\begin{array}{c}0.61^{* * *} \\
(0.07)\end{array}$ \\
\hline GDP growth pc & $\begin{array}{c}-0.04^{* * *} \\
(0.02)\end{array}$ & $\begin{array}{c}-0.04^{* * *} \\
(0.02)\end{array}$ & $\begin{array}{c}-0.04^{* * *} \\
(0.02)\end{array}$ & $\begin{array}{c}-0.04^{* * *} \\
(0.02)\end{array}$ & $\begin{array}{c}-0.04^{* *} \\
(0.01)\end{array}$ \\
\hline DIS index & $\begin{array}{c}-1.56^{* * *} \\
(0.02)\end{array}$ & $\begin{array}{c}-1.57^{* * *} \\
(0.02)\end{array}$ & $\begin{array}{c}-1.56^{* * *} \\
(0.02)\end{array}$ & $\begin{array}{c}-1.56^{* * *} \\
(0.02)\end{array}$ & $\begin{array}{c}-1.55^{* * *} \\
(0.02)\end{array}$ \\
\hline Effec. num. parties (log) & $\begin{array}{l}0.001 \\
(0.02)\end{array}$ & $\begin{array}{l}0.002 \\
(0.02)\end{array}$ & $\begin{array}{l}0.001 \\
(0.02)\end{array}$ & $\begin{array}{l}0.002 \\
(0.02)\end{array}$ & $\begin{array}{l}0.002 \\
(0.02)\end{array}$ \\
\hline State age $(\log )$ & $\begin{array}{l}-0.01 \\
(0.04)\end{array}$ & $\begin{array}{l}-0.02 \\
(0.04)\end{array}$ & $\begin{array}{l}-0.02 \\
(0.04)\end{array}$ & $\begin{array}{l}-0.01 \\
(0.04)\end{array}$ & $\begin{array}{l}-0.01 \\
(0.04)\end{array}$ \\
\hline Internal conflict & $\begin{array}{l}-0.01 \\
(0.01)\end{array}$ & $\begin{array}{l}-0.01 \\
(0.01)\end{array}$ & $\begin{array}{c}-0.001 \\
(0.01)\end{array}$ & $\begin{array}{c}-0.002 \\
(0.01)\end{array}$ & $\begin{array}{l}0.004 \\
(0.01)\end{array}$ \\
\hline Oil income pc & $\begin{array}{c}1.25^{* * *} \\
(0.18)\end{array}$ & $\begin{array}{c}1.25^{* * *} \\
(0.18)\end{array}$ & $\begin{array}{c}1.16^{* * *} \\
(0.18)\end{array}$ & $\begin{array}{c}1.24^{* * *} \\
(0.18)\end{array}$ & $\begin{array}{c}1.14^{* * *} \\
(0.18)\end{array}$ \\
\hline Ethnic frac. & $\begin{array}{c}-1.09^{* * *} \\
(0.21)\end{array}$ & $\begin{array}{c}-1.06^{* * *} \\
(0.21)\end{array}$ & $\begin{array}{c}-1.12^{* * *} \\
(0.22)\end{array}$ & $\begin{array}{c}-1.06^{* * *} \\
(0.22)\end{array}$ & $\begin{array}{c}-1.23^{* * *} \\
(0.22)\end{array}$ \\
\hline Mean region DIS change & $\begin{array}{c}-0.06^{* * *} \\
(0.02)\end{array}$ & $\begin{array}{c}-0.06^{* * *} \\
(0.02)\end{array}$ & $\begin{array}{c}-0.05^{* * *} \\
(0.02)\end{array}$ & $\begin{array}{c}-0.06^{* * *} \\
(0.02)\end{array}$ & $\begin{array}{c}-0.05^{* * *} \\
(0.02)\end{array}$ \\
\hline Lagged DV & $\begin{array}{c}-0.03^{* * *} \\
(0.01)\end{array}$ & $\begin{array}{c}-0.03^{* * *} \\
(0.01)\end{array}$ & $\begin{array}{c}-0.04^{* * *} \\
(0.01)\end{array}$ & $\begin{array}{c}-0.03^{* * *} \\
(0.01)\end{array}$ & $\begin{array}{c}-0.04^{* * *} \\
(0.01)\end{array}$ \\
\hline Observations & 1,302 & 1,302 & 1,302 & 1,302 & 1,302 \\
\hline $\mathrm{R}^{2}$ & 0.89 & 0.89 & 0.89 & 0.89 & 0.89 \\
\hline Adjusted $\mathrm{R}^{2}$ & 0.88 & 0.88 & 0.88 & 0.88 & 0.88 \\
\hline Residual Std. Error $(\mathrm{df}=1186)$ & 0.31 & 0.31 & 0.31 & 0.31 & 0.31 \\
\hline F Statistic $(\mathrm{df}=115 ; 1186)$ & $86.96^{* * *}$ & $86.77^{* * *}$ & $86.31^{* * *}$ & $86.40^{* * *}$ & $87.46^{* * *}$ \\
\hline Country Fixed Effects & $\checkmark$ & $\checkmark$ & $\checkmark$ & $\checkmark$ & $\checkmark$ \\
\hline Year Fixed Effects & $\checkmark$ & $\checkmark$ & $\checkmark$ & $\checkmark$ & $\checkmark$ \\
\hline
\end{tabular}

Note: Dependent variable: 5 -year change in DIS index. ${ }^{* * *} p<0.001,{ }^{* *} p<0.01,{ }^{*} p<0.05$ 


\section{A.3 Number of IO Memberships and Democratic Backsliding: International Factors}

The main results from Table 4.4 linking increased IO membership to democratic backsliding may simply be the result of international factors in general rather than IOs specifically. To test if IOs specifically contribute to backsliding, or if they are simply one aspect of globalization that has made states more likely to backslide, I estimate the same models from Table 4.4, this time including proxies for globalization as control variables. Specifically, I control for a state's foreign direct investment inflow and its trade openness (World Bank, 2017). I also include an indicator for whether an observation occurs following the end of the Cold War since IOs became more involved in democracy promotion in the post-Cold War era. The results are largely the same as those reported in Table 4.4 and can be found in Table A.4. 
Table A.4: Number of IO Memberships and Democratic Backsliding: International Factors

\begin{tabular}{|c|c|c|c|c|c|}
\hline & Demo IO & Non-Univ Demo IO & Pol/Econ IO & Demo Pol/Econ IO & Interven IO \\
\hline Num. IO memberships 5 years prior & $\begin{array}{c}-0.10^{* * *} \\
(0.03)\end{array}$ & $\begin{array}{c}-0.08^{* * *} \\
(0.02)\end{array}$ & $\begin{array}{c}-0.09^{* *} \\
(0.05)\end{array}$ & $\begin{array}{c}-0.07^{* * *} \\
(0.02)\end{array}$ & $\begin{array}{c}-0.18^{* * *} \\
(0.06)\end{array}$ \\
\hline GDP pc (log) & $\begin{array}{c}0.49^{* * *} \\
(0.06)\end{array}$ & $\begin{array}{c}0.48^{* * *} \\
(0.06)\end{array}$ & $\begin{array}{c}0.45^{* * *} \\
(0.06)\end{array}$ & $\begin{array}{c}0.47^{* * *} \\
(0.06)\end{array}$ & $\begin{array}{c}0.45^{* * *} \\
(0.05)\end{array}$ \\
\hline GDP growth pc & $\begin{array}{c}-0.03^{* *} \\
(0.02)\end{array}$ & $\begin{array}{c}-0.03^{* *} \\
(0.02)\end{array}$ & $\begin{array}{c}-0.03^{*} \\
(0.02)\end{array}$ & $\begin{array}{c}-0.03^{* *} \\
(0.02)\end{array}$ & $\begin{array}{c}-0.03^{*} \\
(0.01)\end{array}$ \\
\hline DIS index & $\begin{array}{c}-1.93^{* * *} \\
(0.03)\end{array}$ & $\begin{array}{c}-1.93^{* * *} \\
(0.03)\end{array}$ & $\begin{array}{c}-1.94^{* * *} \\
(0.03)\end{array}$ & $\begin{array}{c}-1.93^{* * *} \\
(0.03)\end{array}$ & $\begin{array}{c}-1.93^{* * *} \\
(0.03)\end{array}$ \\
\hline Effec. num. parties (log) & $\begin{array}{c}0.02 \\
(0.02)\end{array}$ & $\begin{array}{c}0.02 \\
(0.02)\end{array}$ & $\begin{array}{c}0.02 \\
(0.02)\end{array}$ & $\begin{array}{c}0.02 \\
(0.02)\end{array}$ & $\begin{array}{c}0.02 \\
(0.02)\end{array}$ \\
\hline State age $(\log )$ & $\begin{array}{l}-0.02 \\
(0.04)\end{array}$ & $\begin{array}{l}-0.03 \\
(0.04)\end{array}$ & $\begin{array}{l}-0.03 \\
(0.04)\end{array}$ & $\begin{array}{l}-0.02 \\
(0.04)\end{array}$ & $\begin{array}{l}-0.03 \\
(0.04)\end{array}$ \\
\hline Internal conflict & $\begin{array}{l}-0.01 \\
(0.01)\end{array}$ & $\begin{array}{l}-0.01 \\
(0.01)\end{array}$ & $\begin{array}{l}-0.01 \\
(0.01)\end{array}$ & $\begin{array}{l}-0.01 \\
(0.01)\end{array}$ & $\begin{array}{l}-0.01 \\
(0.01)\end{array}$ \\
\hline Oil income pc & $\begin{array}{c}0.96^{* * *} \\
(0.16)\end{array}$ & $\begin{array}{c}0.97^{* * *} \\
(0.16)\end{array}$ & $\begin{array}{c}0.93^{* * *} \\
(0.17)\end{array}$ & $\begin{array}{c}0.97^{* * *} \\
(0.16)\end{array}$ & $\begin{array}{c}0.89^{* * *} \\
(0.17)\end{array}$ \\
\hline Ethnic frac. & $\begin{array}{c}-0.24^{* *} \\
(0.11)\end{array}$ & $\begin{array}{c}-0.24^{* *} \\
(0.11)\end{array}$ & $\begin{array}{c}-0.25^{* *} \\
(0.11)\end{array}$ & $\begin{array}{c}-0.24^{* *} \\
(0.11)\end{array}$ & $\begin{array}{c}-0.26^{* *} \\
(0.11)\end{array}$ \\
\hline Mean region DIS change & $\begin{array}{l}-0.01 \\
(0.02)\end{array}$ & $\begin{array}{l}-0.01 \\
(0.02)\end{array}$ & $\begin{array}{l}-0.00 \\
(0.02)\end{array}$ & $\begin{array}{l}-0.01 \\
(0.02)\end{array}$ & $\begin{array}{l}-0.00 \\
(0.02)\end{array}$ \\
\hline FDI inflow & $\begin{array}{c}0.01 \\
(0.01)\end{array}$ & $\begin{array}{c}0.01 \\
(0.01)\end{array}$ & $\begin{array}{c}0.01 \\
(0.01)\end{array}$ & $\begin{array}{c}0.01 \\
(0.01)\end{array}$ & $\begin{array}{c}0.01 \\
(0.01)\end{array}$ \\
\hline Trade openness & $\begin{array}{c}-0.11^{* * *} \\
(0.03)\end{array}$ & $\begin{array}{c}-0.11^{* * *} \\
(0.03)\end{array}$ & $\begin{array}{c}-0.11^{* * *} \\
(0.03)\end{array}$ & $\begin{array}{c}-0.11^{* * *} \\
(0.03)\end{array}$ & $\begin{array}{c}-0.12^{* * *} \\
(0.03)\end{array}$ \\
\hline Post Cold War & $\begin{array}{l}-0.01 \\
(0.02)\end{array}$ & $\begin{array}{l}-0.00 \\
(0.02)\end{array}$ & $\begin{array}{l}-0.01 \\
(0.02)\end{array}$ & $\begin{array}{l}-0.01 \\
(0.02)\end{array}$ & $\begin{array}{c}0.00 \\
(0.02)\end{array}$ \\
\hline Lagged DV & $\begin{array}{c}-0.03^{* * *} \\
(0.01)\end{array}$ & $\begin{array}{c}-0.03^{* * *} \\
(0.01)\end{array}$ & $\begin{array}{c}-0.03^{* * *} \\
(0.01)\end{array}$ & $\begin{array}{c}-0.03^{* * *} \\
(0.01)\end{array}$ & $\begin{array}{c}-0.03^{* * *} \\
(0.01)\end{array}$ \\
\hline AIC & 1019.77 & 1019.00 & 1026.26 & 1021.34 & 1021.12 \\
\hline $\mathrm{BIC}$ & 1111.88 & 1111.10 & 1118.37 & 1113.45 & 1113.23 \\
\hline Log. lik. & -491.88 & -491.50 & -495.13 & -492.67 & -492.56 \\
\hline Observations & 1233 & 1233 & 1233 & 1233 & 1233 \\
\hline Num. countries & 69 & 69 & 69 & 69 & 69 \\
\hline Num. regions & 15 & 15 & 15 & 15 & 15 \\
\hline Variance: countries & 0.71 & 0.71 & 0.74 & 0.72 & 0.76 \\
\hline Variance: regions & 0.24 & 0.24 & 0.23 & 0.25 & 0.22 \\
\hline Variance: residual & 0.09 & 0.09 & 0.09 & 0.09 & 0.09 \\
\hline
\end{tabular}




\section{A.4 Number of IO Memberships and Democratic Backsliding: 3-, 7-, and 10-Year Changes}

The time period over which backsliding occurs can vary across cases. Therefore, I re-estimate the main models from Table 4.4, which tests the relationship between the number of IOs a state is a member of 5 years prior on the subsequent 5 -year change in its DIS index, for different time periods. Specifically, I use the 3-, 7-, and 10-year changes in a state's DIS index as alternative dependent variables. In these models, all independent variables are lagged by the relevant time period, and all variables are standardized to facilitate interpretation. Overall, the results are similar to those for the 5-year time period. As expected, I find that the impact of IO membership on states' democratic trajectories is relatively small in the short-term (at the 3-year

mark) but increases over time. In fact, the substantive impact of membership is overall the largest at the 7-year mark. The results of these models can be found in Tables A.5, A.6, and A.7. 
Table A.5: Number of IO Memberships and Democratic Backsliding, 3 Years

\begin{tabular}{|c|c|c|c|c|c|}
\hline & Demo IO & Non-Univ Demo IO & Pol/Econ IO & Demo Pol/Econ IO & Interven IO \\
\hline Num. IO memberships 3 years prior & $\begin{array}{c}-0.09^{* * *} \\
(0.03)\end{array}$ & $\begin{array}{c}-0.07^{* * *} \\
(0.02)\end{array}$ & $\begin{array}{l}-0.07 \\
(0.05)\end{array}$ & $\begin{array}{c}-0.06^{* *} \\
(0.03)\end{array}$ & $\begin{array}{c}-0.15^{* *} \\
(0.06)\end{array}$ \\
\hline GDP pc (log) & $0.65^{* * *}$ & $0.64^{* * *}$ & $0.60^{* * *}$ & $0.62^{* * *}$ & $0.61^{* * *}$ \\
\hline GDP growth pc & $\begin{array}{c}(0.07) \\
-0.05^{* *} \\
(0.02)\end{array}$ & $\begin{array}{c}(0.06) \\
-0.05^{* * *} \\
(0.02)\end{array}$ & $\begin{array}{c}(0.06) \\
-0.04^{* *} \\
(0.02)\end{array}$ & $\begin{array}{c}(0.06) \\
-0.05^{* * *} \\
(0.02)\end{array}$ & $\begin{array}{c}(0.06) \\
-0.04^{* *} \\
(0.02)\end{array}$ \\
\hline DIS index & $\begin{array}{c}-2.26^{* * *} \\
(0.04)\end{array}$ & $\begin{array}{c}-2.26^{* * *} \\
(0.04)\end{array}$ & $\begin{array}{c}-2.27^{* * *} \\
(0.04)\end{array}$ & $\begin{array}{c}-2.27^{* * *} \\
(0.04)\end{array}$ & $\begin{array}{c}-2.27^{* * *} \\
(0.04)\end{array}$ \\
\hline Effec. num. parties (log) & $\begin{array}{c}0.03 \\
(0.02)\end{array}$ & $\begin{array}{c}0.03 \\
(0.02)\end{array}$ & $\begin{array}{c}0.03 \\
(0.02)\end{array}$ & $\begin{array}{c}0.03 \\
(0.02)\end{array}$ & $\begin{array}{c}0.03 \\
(0.02)\end{array}$ \\
\hline State age $(\log )$ & $\begin{array}{l}-0.02 \\
(0.04)\end{array}$ & $\begin{array}{l}-0.03 \\
(0.04)\end{array}$ & $\begin{array}{l}-0.03 \\
(0.04)\end{array}$ & $\begin{array}{l}-0.03 \\
(0.04)\end{array}$ & $\begin{array}{l}-0.03 \\
(0.04)\end{array}$ \\
\hline Internal conflict & $\begin{array}{l}-0.01 \\
(0.02)\end{array}$ & $\begin{array}{l}-0.01 \\
(0.02)\end{array}$ & $\begin{array}{l}-0.01 \\
(0.02)\end{array}$ & $\begin{array}{l}-0.01 \\
(0.02)\end{array}$ & $\begin{array}{l}-0.01 \\
(0.02)\end{array}$ \\
\hline Oil income pc & $\begin{array}{c}0.87^{* * *} \\
(0.20)\end{array}$ & $\begin{array}{c}0.86^{* * *} \\
(0.20)\end{array}$ & $\begin{array}{c}0.86^{* * *} \\
(0.21)\end{array}$ & $\begin{array}{c}0.89^{* * *} \\
(0.20)\end{array}$ & $\begin{array}{c}0.81^{* * *} \\
(0.21)\end{array}$ \\
\hline Ethnic frac. & $\begin{array}{c}-0.29^{* *} \\
(0.12)\end{array}$ & $\begin{array}{c}-0.29^{* *} \\
(0.12)\end{array}$ & $\begin{array}{c}-0.31^{* *} \\
(0.12)\end{array}$ & $\begin{array}{c}-0.30^{* *} \\
(0.12)\end{array}$ & $\begin{array}{c}-0.30^{* *} \\
(0.12)\end{array}$ \\
\hline Mean region DIS change & $\begin{array}{c}0.05^{* * *} \\
(0.02)\end{array}$ & $\begin{array}{c}0.05^{* * *} \\
(0.02)\end{array}$ & $\begin{array}{c}0.06^{* * *} \\
(0.02)\end{array}$ & $\begin{array}{c}0.05^{* * *} \\
(0.02)\end{array}$ & $\begin{array}{c}0.06^{* * *} \\
(0.02)\end{array}$ \\
\hline Lagged DV & $\begin{array}{l}-0.01 \\
(0.01)\end{array}$ & $\begin{array}{l}-0.01 \\
(0.01)\end{array}$ & $\begin{array}{l}-0.00 \\
(0.01)\end{array}$ & $\begin{array}{l}-0.00 \\
(0.01)\end{array}$ & $\begin{array}{l}-0.01 \\
(0.01)\end{array}$ \\
\hline $\mathrm{AIC}$ & 1889.42 & 1890.48 & 1893.96 & 1892.79 & 1889.79 \\
\hline $\mathrm{BIC}$ & 1968.18 & 1969.24 & 1972.72 & 1971.55 & 1968.55 \\
\hline Log. lik. & -929.71 & -930.24 & -931.98 & -931.40 & -929.89 \\
\hline Observations & 1409 & 1409 & 1409 & 1409 & 1409 \\
\hline Num. countries & 70 & 70 & 70 & 70 & 70 \\
\hline Num. regions & 15 & 15 & 15 & 15 & 15 \\
\hline Variance: countries & 0.92 & 0.91 & 0.94 & 0.93 & 0.95 \\
\hline Variance: regions & 0.28 & 0.29 & 0.28 & 0.29 & 0.25 \\
\hline Variance: residual & 0.17 & 0.17 & 0.17 & 0.17 & 0.17 \\
\hline
\end{tabular}

Note: Dependent variable: 3 -year change in DIS index. ${ }^{* * *} p<0.001,{ }^{* *} p<0.01,{ }^{*} p<0.05$ 
Table A.6: Number of IO Memberships and Democratic Backsliding, 7 Years

\begin{tabular}{|c|c|c|c|c|c|}
\hline & Demo IO & Non-Univ Demo IO & Pol/Econ IO & Demo $\mathrm{Pol} /$ Econ IO & Interven IO \\
\hline Num. IO memberships 7 years prior & $\begin{array}{c}-0.18^{* * *} \\
(0.03)\end{array}$ & $\begin{array}{c}-0.12^{* * *} \\
(0.02)\end{array}$ & $\begin{array}{c}-0.27^{* * *} \\
(0.04)\end{array}$ & $\begin{array}{c}-0.12^{* * *} \\
(0.02)\end{array}$ & $\begin{array}{c}-0.28^{* * *} \\
(0.05)\end{array}$ \\
\hline GDP pc (log) & $\begin{array}{c}0.56^{* * *} \\
(0.05)\end{array}$ & $\begin{array}{c}0.52^{* * *} \\
(0.05)\end{array}$ & $\begin{array}{c}0.55^{* * *} \\
(0.05)\end{array}$ & $\begin{array}{c}0.51^{* * *} \\
(0.05)\end{array}$ & $\begin{array}{c}0.50^{* * *} \\
(0.05)\end{array}$ \\
\hline GDP growth pc & $\begin{array}{c}-0.05^{* * *} \\
(0.01)\end{array}$ & $\begin{array}{c}-0.05^{* * *} \\
(0.01)\end{array}$ & $\begin{array}{c}-0.05^{* * *} \\
(0.01)\end{array}$ & $\begin{array}{c}-0.05^{* * *} \\
(0.01)\end{array}$ & $\begin{array}{c}-0.04^{* * *} \\
(0.01)\end{array}$ \\
\hline DIS index & $\begin{array}{c}-1.79^{* * *} \\
(0.03)\end{array}$ & $\begin{array}{c}-1.79^{* * *} \\
(0.03)\end{array}$ & $\begin{array}{c}-1.79^{* * *} \\
(0.03)\end{array}$ & $\begin{array}{c}-1.81^{* * *} \\
(0.03)\end{array}$ & $\begin{array}{c}-1.79^{* * *} \\
(0.03)\end{array}$ \\
\hline Effec. num. parties (log) & $\begin{array}{c}-0.03^{* *} \\
(0.01)\end{array}$ & $\begin{array}{c}-0.03^{* *} \\
(0.01)\end{array}$ & $\begin{array}{c}-0.03^{* *} \\
(0.01)\end{array}$ & $\begin{array}{c}-0.03^{* *} \\
(0.01)\end{array}$ & $\begin{array}{c}-0.03^{* *} \\
(0.01)\end{array}$ \\
\hline State age $(\log )$ & $\begin{array}{l}-0.00 \\
(0.05)\end{array}$ & $\begin{array}{l}-0.02 \\
(0.05)\end{array}$ & $\begin{array}{l}-0.03 \\
(0.05)\end{array}$ & $\begin{array}{l}-0.02 \\
(0.05)\end{array}$ & $\begin{array}{l}-0.04 \\
(0.05)\end{array}$ \\
\hline Internal conflict & $\begin{array}{c}0.00 \\
(0.01)\end{array}$ & $\begin{array}{c}0.00 \\
(0.01)\end{array}$ & $\begin{array}{c}0.01 \\
(0.01)\end{array}$ & $\begin{array}{c}0.01 \\
(0.01)\end{array}$ & $\begin{array}{c}0.02 \\
(0.01)\end{array}$ \\
\hline Oil income pc & $\begin{array}{c}1.05^{* * *} \\
(0.15)\end{array}$ & $\begin{array}{c}1.04^{* * *} \\
(0.15)\end{array}$ & $\begin{array}{c}0.88^{* * *} \\
(0.16)\end{array}$ & $\begin{array}{c}1.06^{* * *} \\
(0.15)\end{array}$ & $\begin{array}{c}0.88^{* * *} \\
(0.16)\end{array}$ \\
\hline Ethnic frac. & $\begin{array}{c}-0.23^{* *} \\
(0.11)\end{array}$ & $\begin{array}{c}-0.23^{* *} \\
(0.11)\end{array}$ & $\begin{array}{c}-0.23^{* *} \\
(0.11)\end{array}$ & $\begin{array}{c}-0.24^{* *} \\
(0.11)\end{array}$ & $\begin{array}{c}-0.27^{* *} \\
(0.11)\end{array}$ \\
\hline Mean region DIS change & $\begin{array}{c}-0.04^{* * *} \\
(0.01)\end{array}$ & $\begin{array}{c}-0.04^{* * *} \\
(0.02)\end{array}$ & $\begin{array}{c}-0.04^{* *} \\
(0.01)\end{array}$ & $\begin{array}{c}-0.04^{* *} \\
(0.01)\end{array}$ & $\begin{array}{c}-0.02^{*} \\
(0.01)\end{array}$ \\
\hline Lagged DV & $\begin{array}{c}-0.03^{* * *} \\
(0.01)\end{array}$ & $\begin{array}{c}-0.03^{* * *} \\
(0.01)\end{array}$ & $\begin{array}{c}-0.03^{* * *} \\
(0.01)\end{array}$ & $\begin{array}{c}-0.03^{* * *} \\
(0.01)\end{array}$ & $\begin{array}{c}-0.03^{* * *} \\
(0.01)\end{array}$ \\
\hline $\mathrm{AIC}$ & 777.95 & 787.16 & 784.83 & 792.98 & 793.47 \\
\hline $\mathrm{BIC}$ & 853.09 & 862.31 & 859.97 & 868.12 & 868.61 \\
\hline Log. lik. & -373.97 & -378.58 & -377.42 & -381.49 & -381.73 \\
\hline Observations & 1107 & 1107 & 1107 & 1107 & 1107 \\
\hline Num. countries & 70 & 70 & 70 & 70 & 70 \\
\hline Num. regions & 15 & 15 & 15 & 15 & 15 \\
\hline Variance: countries & 0.64 & 0.64 & 0.64 & 0.65 & 0.71 \\
\hline Variance: regions & 0.24 & 0.25 & 0.24 & 0.26 & 0.19 \\
\hline Variance: residual & 0.08 & 0.08 & 0.08 & 0.08 & 0.08 \\
\hline
\end{tabular}

Note: Dependent variable: 7 -year change in DIS index. ${ }^{* * *} p<0.001,{ }^{* *} p<0.01,{ }^{*} p<0.05$ 
Table A.7: Number of IO Memberships and Democratic Backsliding, 10 Years

\begin{tabular}{|c|c|c|c|c|c|}
\hline & Demo IO & Non-Univ Demo IO & $\mathrm{Pol} /$ Econ IO & Demo Pol/Econ IO & Interven $\mathrm{IO}$ \\
\hline \multirow[t]{2}{*}{ Num. IO memberships 10 years prior } & $-0.10^{* * *}$ & $-0.05^{* * *}$ & $-0.13^{* * *}$ & $-0.05^{* * *}$ & $-0.13^{* * *}$ \\
\hline & $(0.02)$ & $(0.02)$ & $(0.04)$ & $(0.02)$ & $(0.04)$ \\
\hline \multirow[t]{2}{*}{ GDP pc (log) } & $0.48^{* * *}$ & $0.45^{* * *}$ & $0.46^{* * *}$ & $0.44^{* * *}$ & $0.44^{* * *}$ \\
\hline & $(0.05)$ & $(0.05)$ & $(0.05)$ & $(0.05)$ & $(0.05)$ \\
\hline \multirow[t]{2}{*}{ GDP growth pc } & $-0.04^{* * *}$ & $-0.04^{* * *}$ & $-0.04^{* * *}$ & $-0.04^{* * *}$ & $-0.04^{* * *}$ \\
\hline & $(0.01)$ & $(0.01)$ & $(0.01)$ & $(0.01)$ & $(0.01)$ \\
\hline \multirow[t]{2}{*}{ DIS index } & $-1.56^{* * *}$ & $-1.57^{* * *}$ & $-1.56^{* * *}$ & $-1.57^{* * *}$ & $-1.56^{* * *}$ \\
\hline & $(0.02)$ & $(0.02)$ & $(0.02)$ & $(0.02)$ & $(0.02)$ \\
\hline \multirow[t]{2}{*}{ Effec. num. parties (log) } & $-0.02^{*}$ & $-0.02^{*}$ & $-0.02^{* *}$ & $-0.02^{*}$ & $-0.02^{* *}$ \\
\hline & $(0.01)$ & $(0.01)$ & $(0.01)$ & $(0.01)$ & $(0.01)$ \\
\hline \multirow[t]{2}{*}{ State age $(\log )$} & -0.01 & -0.02 & -0.02 & -0.03 & -0.03 \\
\hline & $(0.03)$ & $(0.03)$ & $(0.03)$ & $(0.03)$ & $(0.03)$ \\
\hline \multirow[t]{2}{*}{ Internal conflict } & $0.02^{*}$ & $0.02^{* *}$ & $0.02^{* *}$ & $0.02^{* *}$ & $0.03^{* * *}$ \\
\hline & $(0.01)$ & $(0.01)$ & $(0.01)$ & $(0.01)$ & $(0.01)$ \\
\hline \multirow{2}{*}{ Oil income pc } & $1.06^{* * *}$ & $1.06^{* * *}$ & $0.98^{* * *}$ & $1.06^{* * *}$ & $0.96^{* * *}$ \\
\hline & $(0.13)$ & $(0.13)$ & $(0.13)$ & $(0.13)$ & $(0.13)$ \\
\hline \multirow[t]{2}{*}{ Ethnic frac. } & $-0.17^{*}$ & $-0.17^{*}$ & $-0.18^{* *}$ & $-0.18^{* *}$ & $-0.19^{* *}$ \\
\hline & $(0.09)$ & $(0.09)$ & $(0.09)$ & $(0.09)$ & $(0.09)$ \\
\hline \multirow[t]{2}{*}{ Mean region DIS change } & $-0.05^{* * *}$ & $-0.04^{* * *}$ & $-0.04^{* * *}$ & $-0.04^{* * *}$ & $-0.03^{* * *}$ \\
\hline & $(0.01)$ & $(0.01)$ & $(0.01)$ & $(0.01)$ & $(0.01)$ \\
\hline \multirow[t]{2}{*}{ Lagged DV } & $0.02^{* * *}$ & $0.03^{* * *}$ & $0.03^{* * *}$ & $0.03^{* * *}$ & $0.03^{* * *}$ \\
\hline & $(0.01)$ & $(0.01)$ & $(0.01)$ & $(0.01)$ & $(0.01)$ \\
\hline $\mathrm{AIC}$ & 287.51 & 297.96 & 296.82 & 301.86 & 298.39 \\
\hline $\mathrm{BIC}$ & 361.38 & 371.83 & 370.69 & 375.73 & 372.26 \\
\hline Log. lik. & -128.76 & -133.98 & -133.41 & -135.93 & -134.19 \\
\hline Observations & 1017 & 1017 & 1017 & 1017 & 1017 \\
\hline Num. countries & 69 & 69 & 69 & 69 & 69 \\
\hline Num. regions & 15 & 15 & 15 & 15 & 15 \\
\hline Variance: countries & 0.48 & 0.49 & 0.49 & 0.50 & 0.51 \\
\hline Variance: regions & 0.11 & 0.12 & 0.11 & 0.12 & 0.09 \\
\hline Variance: residual & 0.05 & 0.05 & 0.05 & 0.05 & 0.05 \\
\hline
\end{tabular}

Note: Dependent variable: 10 -year change in DIS index. ${ }^{* * *} p<0.001,{ }^{* *} p<0.01,{ }^{*} p<0.05$ 


\section{A.5 Number of IO Memberships and Democratic Backsliding: International Factors, 3-, 7-, and 10-Year Changes}

I re-estimate the models that control for international factors as a proxy for globalization from Appendix A.3 for additional time periods as well. As in Appendix A.4, I consider the 3-, 7-, and 10-year changes in a state's level of democracy as well. The results of these models can be found in Tables A.8, A.9, and A.10. 
Table A.8: Number of IO Memberships and Democratic Backsliding: International Factors, 3 Years

\begin{tabular}{|c|c|c|c|c|c|}
\hline & Demo IO & Non-Univ Demo IO & Pol/Econ IO & Demo Pol/Econ IO & Interven IO \\
\hline Num. IO memberships 3 years prior & $\begin{array}{c}-0.03 \\
(0.04)\end{array}$ & $\begin{array}{l}-0.03 \\
(0.03)\end{array}$ & $\begin{array}{c}0.01 \\
(0.06)\end{array}$ & $\begin{array}{l}-0.02 \\
(0.03)\end{array}$ & $\begin{array}{l}-0.12 \\
(0.08)\end{array}$ \\
\hline GDP pc $(\log )$ & $0.56^{* * *}$ & $0.56^{* * *}$ & $0.53^{* * *}$ & $0.55^{* * *}$ & $0.57^{* * *}$ \\
\hline & $(0.07)$ & $(0.07)$ & $(0.07)$ & $(0.07)$ & $(0.06)$ \\
\hline GDP growth pc & -0.02 & -0.02 & -0.02 & -0.02 & -0.02 \\
\hline & $(0.02)$ & $(0.02)$ & $(0.02)$ & $(0.02)$ & $(0.02)$ \\
\hline DIS index & $\begin{array}{c}-2.27^{* * *} \\
(0.04)\end{array}$ & $\begin{array}{c}-2.27^{* * *} \\
(0.04)\end{array}$ & $\begin{array}{c}-2.28^{* * *} \\
(0.04)\end{array}$ & $\begin{array}{c}-2.28^{* * *} \\
(0.04)\end{array}$ & $\begin{array}{c}-2.27^{* * *} \\
(0.04)\end{array}$ \\
\hline Effec. num. parties (log) & $\begin{array}{l}0.04^{*} \\
(0.02)\end{array}$ & $\begin{array}{l}0.04^{*} \\
(0.02)\end{array}$ & $\begin{array}{l}0.04^{*} \\
(0.02)\end{array}$ & $\begin{array}{l}0.04^{*} \\
(0.02)\end{array}$ & $\begin{array}{l}0.04^{*} \\
(0.02)\end{array}$ \\
\hline State age $(\log )$ & $\begin{array}{l}-0.05 \\
(0.04)\end{array}$ & $\begin{array}{l}-0.05 \\
(0.04)\end{array}$ & $\begin{array}{l}-0.06 \\
(0.04)\end{array}$ & $\begin{array}{l}-0.05 \\
(0.04)\end{array}$ & $\begin{array}{l}-0.05 \\
(0.04)\end{array}$ \\
\hline Internal conflict & $\begin{array}{l}-0.02 \\
(0.02)\end{array}$ & $\begin{array}{l}-0.02 \\
(0.02)\end{array}$ & $\begin{array}{l}-0.02 \\
(0.02)\end{array}$ & $\begin{array}{l}-0.02 \\
(0.02)\end{array}$ & $\begin{array}{l}-0.02 \\
(0.02)\end{array}$ \\
\hline Oil income pc & $\begin{array}{c}0.95^{* * *} \\
(0.20)\end{array}$ & $\begin{array}{c}0.95^{* * *} \\
(0.20)\end{array}$ & $\begin{array}{c}0.97^{* * *} \\
(0.21)\end{array}$ & $\begin{array}{c}0.96^{* * *} \\
(0.20)\end{array}$ & $\begin{array}{c}0.90^{* * * *} \\
(0.21)\end{array}$ \\
\hline Ethnic frac. & $\begin{array}{c}-0.26^{* *} \\
(0.13)\end{array}$ & $\begin{array}{c}-0.26^{* *} \\
(0.13)\end{array}$ & $\begin{array}{c}-0.27^{* *} \\
(0.13)\end{array}$ & $\begin{array}{c}-0.26^{* *} \\
(0.13)\end{array}$ & $\begin{array}{c}-0.26^{* *} \\
(0.13)\end{array}$ \\
\hline Mean region DIS change & $\begin{array}{l}0.04^{* *} \\
(0.02)\end{array}$ & $\begin{array}{l}0.04^{* *} \\
(0.02)\end{array}$ & $\begin{array}{l}0.05^{* *} \\
(0.02)\end{array}$ & $\begin{array}{l}0.04^{* *} \\
(0.02)\end{array}$ & $\begin{array}{c}0.04^{* *} \\
(0.02)\end{array}$ \\
\hline FDI inflow & $\begin{array}{c}0.01 \\
(0.02)\end{array}$ & $\begin{array}{c}0.01 \\
(0.02)\end{array}$ & $\begin{array}{c}0.01 \\
(0.02)\end{array}$ & $\begin{array}{c}0.01 \\
(0.02)\end{array}$ & $\begin{array}{c}0.01 \\
(0.02)\end{array}$ \\
\hline Trade openness & $\begin{array}{c}-0.11^{* * *} \\
(0.04)\end{array}$ & $\begin{array}{c}-0.11^{* * *} \\
(0.04)\end{array}$ & $\begin{array}{c}-0.11^{* * *} \\
(0.04)\end{array}$ & $\begin{array}{c}-0.11^{* * *} \\
(0.04)\end{array}$ & $\begin{array}{c}-0.11^{* * *} \\
(0.04)\end{array}$ \\
\hline Post Cold War & $\begin{array}{c}0.00 \\
(0.02)\end{array}$ & $\begin{array}{c}0.01 \\
(0.02)\end{array}$ & $\begin{array}{l}-0.00 \\
(0.02)\end{array}$ & $\begin{array}{c}0.00 \\
(0.02)\end{array}$ & $\begin{array}{c}0.02 \\
(0.02)\end{array}$ \\
\hline Lagged DV & $\begin{array}{c}0.01 \\
(0.01)\end{array}$ & $\begin{array}{c}0.01 \\
(0.01)\end{array}$ & $\begin{array}{c}0.01 \\
(0.01)\end{array}$ & $\begin{array}{c}0.01 \\
(0.01)\end{array}$ & $\begin{array}{c}0.00 \\
(0.01)\end{array}$ \\
\hline AIC & 1779.09 & 1779.30 & 1778.79 & 1779.78 & 1775.57 \\
\hline $\mathrm{BIC}$ & 1872.79 & 1873.00 & 1872.49 & 1873.48 & 1869.27 \\
\hline Log. lik. & -871.54 & -871.65 & -871.40 & -871.89 & -869.78 \\
\hline Observations & 1347 & 1347 & 1347 & 1347 & 1347 \\
\hline Num. countries & 69 & 69 & 69 & 69 & 69 \\
\hline Num. regions & 15 & 15 & 15 & 15 & 15 \\
\hline Variance: countries & 0.98 & 0.97 & 0.99 & 0.98 & 0.98 \\
\hline Variance: regions & 0.28 & 0.29 & 0.28 & 0.28 & 0.27 \\
\hline Variance: residual & 0.16 & 0.16 & 0.16 & 0.16 & 0.16 \\
\hline
\end{tabular}


Table A.9: Number of IO Memberships and Democratic Backsliding: International Factors, 7 Years

\begin{tabular}{|c|c|c|c|c|c|}
\hline & Demo IO & Non-Univ Demo IO & Pol/Econ IO & Demo Pol/Econ IO & Interven IO \\
\hline Num. IO memberships 7 years prior & $\begin{array}{c}-0.13^{* * *} \\
(0.03)\end{array}$ & $\begin{array}{c}-0.08^{* * *} \\
(0.02)\end{array}$ & $\begin{array}{c}-0.17^{* * *} \\
(0.05)\end{array}$ & $\begin{array}{c}-0.09^{* * *} \\
(0.02)\end{array}$ & $\begin{array}{c}-0.22^{* * *} \\
(0.06)\end{array}$ \\
\hline GDP pc (log) & $\begin{array}{c}0.50^{* * *} \\
(0.06)\end{array}$ & $\begin{array}{c}0.46^{* * *} \\
(0.06)\end{array}$ & $\begin{array}{c}0.47^{* * *} \\
(0.06)\end{array}$ & $\begin{array}{c}0.46^{* * *} \\
(0.06)\end{array}$ & $\begin{array}{c}0.45^{* * *} \\
(0.06)\end{array}$ \\
\hline GDP growth pc & $\begin{array}{c}-0.04^{* *} \\
(0.01)\end{array}$ & $\begin{array}{c}-0.04^{* *} \\
(0.01)\end{array}$ & $\begin{array}{c}-0.03^{* *} \\
(0.01)\end{array}$ & $\begin{array}{c}-0.04^{* *} \\
(0.01)\end{array}$ & $\begin{array}{c}-0.03^{* *} \\
(0.01)\end{array}$ \\
\hline DIS index & $\begin{array}{c}-1.77^{* * *} \\
(0.03)\end{array}$ & $\begin{array}{c}-1.77^{* * *} \\
(0.03)\end{array}$ & $\begin{array}{c}-1.78^{* * *} \\
(0.03)\end{array}$ & $\begin{array}{c}-1.77^{* * *} \\
(0.03)\end{array}$ & $\begin{array}{c}-1.78^{* * *} \\
(0.03)\end{array}$ \\
\hline Effec. num. parties (log) & $\begin{array}{l}-0.02 \\
(0.02)\end{array}$ & $\begin{array}{l}-0.02 \\
(0.02)\end{array}$ & $\begin{array}{l}-0.02 \\
(0.02)\end{array}$ & $\begin{array}{l}-0.02 \\
(0.02)\end{array}$ & $\begin{array}{l}-0.02 \\
(0.02)\end{array}$ \\
\hline State age $(\log )$ & $\begin{array}{l}-0.01 \\
(0.05)\end{array}$ & $\begin{array}{l}-0.02 \\
(0.05)\end{array}$ & $\begin{array}{l}-0.03 \\
(0.05)\end{array}$ & $\begin{array}{l}-0.01 \\
(0.05)\end{array}$ & $\begin{array}{l}-0.04 \\
(0.05)\end{array}$ \\
\hline Internal conflict & $\begin{array}{l}-0.01 \\
(0.01)\end{array}$ & $\begin{array}{l}-0.00 \\
(0.01)\end{array}$ & $\begin{array}{l}-0.00 \\
(0.01)\end{array}$ & $\begin{array}{l}-0.00 \\
(0.01)\end{array}$ & $\begin{array}{c}0.00 \\
(0.01)\end{array}$ \\
\hline Oil income pc & $\begin{array}{c}1.05^{* * *} \\
(0.15)\end{array}$ & $\begin{array}{c}1.05^{* * *} \\
(0.15)\end{array}$ & $\begin{array}{c}0.96^{* * *} \\
(0.15)\end{array}$ & $\begin{array}{c}1.05^{* * *} \\
(0.15)\end{array}$ & $\begin{array}{c}0.95^{* * *} \\
(0.15)\end{array}$ \\
\hline Ethnic frac. & $\begin{array}{c}-0.21^{*} \\
(0.11)\end{array}$ & $\begin{array}{c}-0.22^{* *} \\
(0.11)\end{array}$ & $\begin{array}{c}-0.22^{* *} \\
(0.11)\end{array}$ & $\begin{array}{c}-0.22^{* *} \\
(0.11)\end{array}$ & $\begin{array}{c}-0.23^{* *} \\
(0.11)\end{array}$ \\
\hline Mean region DIS change & $\begin{array}{c}-0.04^{* *} \\
(0.02)\end{array}$ & $\begin{array}{c}-0.04^{* *} \\
(0.02)\end{array}$ & $\begin{array}{c}-0.03^{*} \\
(0.02)\end{array}$ & $\begin{array}{c}-0.03^{* *} \\
(0.02)\end{array}$ & $\begin{array}{l}-0.02 \\
(0.02)\end{array}$ \\
\hline FDI inflow & $\begin{array}{l}-0.01 \\
(0.01)\end{array}$ & $\begin{array}{l}-0.01 \\
(0.01)\end{array}$ & $\begin{array}{l}-0.01 \\
(0.01)\end{array}$ & $\begin{array}{l}-0.01 \\
(0.01)\end{array}$ & $\begin{array}{l}-0.01 \\
(0.01)\end{array}$ \\
\hline Trade openness & $\begin{array}{c}-0.12^{* * *} \\
(0.03)\end{array}$ & $\begin{array}{c}-0.12^{* * *} \\
(0.03)\end{array}$ & $\begin{array}{c}-0.12^{* * *} \\
(0.03)\end{array}$ & $\begin{array}{c}-0.12^{* * *} \\
(0.03)\end{array}$ & $\begin{array}{c}-0.13^{* * *} \\
(0.03)\end{array}$ \\
\hline Post Cold War & $\begin{array}{l}-0.02 \\
(0.02)\end{array}$ & $\begin{array}{l}-0.02 \\
(0.02)\end{array}$ & $\begin{array}{l}-0.01 \\
(0.02)\end{array}$ & $\begin{array}{l}-0.02 \\
(0.02)\end{array}$ & $\begin{array}{l}-0.00 \\
(0.02)\end{array}$ \\
\hline Lagged DV & $\begin{array}{c}-0.04^{* * *} \\
(0.01)\end{array}$ & $\begin{array}{c}-0.04^{* * *} \\
(0.01)\end{array}$ & $\begin{array}{c}-0.04^{* * *} \\
(0.01)\end{array}$ & $\begin{array}{c}-0.04^{* * *} \\
(0.01)\end{array}$ & $\begin{array}{c}-0.04^{* * *} \\
(0.01)\end{array}$ \\
\hline AIC & 706.71 & 712.08 & 711.74 & 710.74 & 712.18 \\
\hline $\mathrm{BIC}$ & 795.71 & 801.07 & 800.74 & 799.73 & 801.17 \\
\hline Log. lik. & -335.36 & -338.04 & -337.87 & -337.37 & -338.09 \\
\hline Observations & 1037 & 1037 & 1037 & 1037 & 1037 \\
\hline Num. countries & 68 & 68 & 68 & 68 & 68 \\
\hline Num. regions & 15 & 15 & 15 & 15 & 15 \\
\hline Variance: countries & 0.63 & 0.64 & 0.64 & 0.64 & 0.68 \\
\hline Variance: regions & 0.24 & 0.24 & 0.23 & 0.25 & 0.21 \\
\hline Variance: residual & 0.08 & 0.08 & 0.08 & 0.08 & 0.08 \\
\hline
\end{tabular}


Table A.10: Number of IO Memberships and Democratic Backsliding: International Factors, 10 Years

\begin{tabular}{|c|c|c|c|c|c|}
\hline & Demo IO & Non-Univ Demo IO & Pol/Econ IO & Demo Pol/Econ IO & Interven IO \\
\hline Num. IO memberships 10 years prior & $\begin{array}{c}-0.06^{* *} \\
(0.02)\end{array}$ & $\begin{array}{l}-0.02 \\
(0.02)\end{array}$ & $\begin{array}{l}-0.05 \\
(0.04)\end{array}$ & $\begin{array}{c}-0.03^{*} \\
(0.02)\end{array}$ & $\begin{array}{l}-0.02 \\
(0.05)\end{array}$ \\
\hline GDP pc (log) & $\begin{array}{c}0.37^{* * *} \\
(0.06)\end{array}$ & $\begin{array}{c}0.34^{* * *} \\
(0.05)\end{array}$ & $\begin{array}{c}0.34^{* * *} \\
(0.05)\end{array}$ & $\begin{array}{c}0.34^{* * *} \\
(0.05)\end{array}$ & $\begin{array}{c}0.32^{* * *} \\
(0.05)\end{array}$ \\
\hline GDP growth pc & $\begin{array}{c}-0.03^{* * *} \\
(0.01)\end{array}$ & $\begin{array}{c}-0.03^{* * *} \\
(0.01)\end{array}$ & $\begin{array}{c}-0.03^{* * *} \\
(0.01)\end{array}$ & $\begin{array}{c}-0.03^{* * *} \\
(0.01)\end{array}$ & $\begin{array}{c}-0.03^{* * *} \\
(0.01)\end{array}$ \\
\hline DIS index & $\begin{array}{c}-1.53^{* * *} \\
(0.02)\end{array}$ & $\begin{array}{c}-1.54^{* * *} \\
(0.02)\end{array}$ & $\begin{array}{c}-1.54^{* * *} \\
(0.02)\end{array}$ & $\begin{array}{c}-1.54^{* * *} \\
(0.02)\end{array}$ & $\begin{array}{c}-1.55^{* * *} \\
(0.02)\end{array}$ \\
\hline Effec. num. parties (log) & $\begin{array}{l}-0.01 \\
(0.01)\end{array}$ & $\begin{array}{l}-0.01 \\
(0.01)\end{array}$ & $\begin{array}{l}-0.01 \\
(0.01)\end{array}$ & $\begin{array}{l}-0.01 \\
(0.01)\end{array}$ & $\begin{array}{l}-0.01 \\
(0.01)\end{array}$ \\
\hline State age $(\log )$ & $\begin{array}{l}-0.02 \\
(0.03)\end{array}$ & $\begin{array}{l}-0.03 \\
(0.03)\end{array}$ & $\begin{array}{l}-0.03 \\
(0.03)\end{array}$ & $\begin{array}{l}-0.03 \\
(0.03)\end{array}$ & $\begin{array}{l}-0.04 \\
(0.03)\end{array}$ \\
\hline Internal conflict & $\begin{array}{c}0.01 \\
(0.01)\end{array}$ & $\begin{array}{c}0.01 \\
(0.01)\end{array}$ & $\begin{array}{c}0.01 \\
(0.01)\end{array}$ & $\begin{array}{c}0.01 \\
(0.01)\end{array}$ & $\begin{array}{c}0.01 \\
(0.01)\end{array}$ \\
\hline Oil income pc & $\begin{array}{c}1.05^{* * *} \\
(0.13)\end{array}$ & $\begin{array}{c}1.05^{* * *} \\
(0.13)\end{array}$ & $\begin{array}{c}1.02^{* * *} \\
(0.13)\end{array}$ & $\begin{array}{c}1.05^{* * *} \\
(0.13)\end{array}$ & $\begin{array}{c}1.03^{* * *} \\
(0.13)\end{array}$ \\
\hline Ethnic frac. & $\begin{array}{c}-0.20^{* *} \\
(0.10)\end{array}$ & $\begin{array}{c}-0.21^{* *} \\
(0.10)\end{array}$ & $\begin{array}{c}-0.21^{* *} \\
(0.10)\end{array}$ & $\begin{array}{c}-0.21^{* *} \\
(0.10)\end{array}$ & $\begin{array}{c}-0.22^{* *} \\
(0.10)\end{array}$ \\
\hline Mean region DIS change & $\begin{array}{c}-0.04^{* * *} \\
(0.01)\end{array}$ & $\begin{array}{c}-0.03^{* *} \\
(0.01)\end{array}$ & $\begin{array}{c}-0.03^{* *} \\
(0.01)\end{array}$ & $\begin{array}{c}-0.03^{* *} \\
(0.01)\end{array}$ & $\begin{array}{c}-0.03^{*} \\
(0.01)\end{array}$ \\
\hline FDI inflow & $\begin{array}{c}0.02 \\
(0.02)\end{array}$ & $\begin{array}{c}0.02 \\
(0.02)\end{array}$ & $\begin{array}{c}0.02 \\
(0.02)\end{array}$ & $\begin{array}{c}0.02 \\
(0.02)\end{array}$ & $\begin{array}{c}0.01 \\
(0.02)\end{array}$ \\
\hline Trade openness & $\begin{array}{c}-0.11^{* * *} \\
(0.03)\end{array}$ & $\begin{array}{c}-0.11^{* * *} \\
(0.03)\end{array}$ & $\begin{array}{c}-0.11^{* * *} \\
(0.03)\end{array}$ & $\begin{array}{c}-0.11^{* * *} \\
(0.03)\end{array}$ & $\begin{array}{c}-0.11^{* * *} \\
(0.03)\end{array}$ \\
\hline Post Cold War & $\begin{array}{l}-0.02 \\
(0.01)\end{array}$ & $\begin{array}{l}-0.02 \\
(0.01)\end{array}$ & $\begin{array}{l}-0.01 \\
(0.01)\end{array}$ & $\begin{array}{l}-0.02 \\
(0.01)\end{array}$ & $\begin{array}{l}-0.02 \\
(0.01)\end{array}$ \\
\hline Lagged DV & $\begin{array}{l}0.02^{*} \\
(0.01)\end{array}$ & $\begin{array}{c}0.02^{* *} \\
(0.01)\end{array}$ & $\begin{array}{c}0.02^{* *} \\
(0.01)\end{array}$ & $\begin{array}{c}0.02^{* *} \\
(0.01)\end{array}$ & $\begin{array}{c}0.02^{* * *} \\
(0.01)\end{array}$ \\
\hline AIC & 215.80 & 220.61 & 219.57 & 219.56 & 220.31 \\
\hline $\mathrm{BIC}$ & 302.89 & 307.70 & 306.66 & 306.65 & 307.40 \\
\hline Log. lik. & -89.90 & -92.30 & -91.78 & -91.78 & -92.15 \\
\hline Observations & 933 & 933 & 933 & 933 & 933 \\
\hline Num. countries & 66 & 66 & 66 & 66 & 66 \\
\hline Num. regions & 15 & 15 & 15 & 15 & 15 \\
\hline Variance: countries & 0.51 & 0.52 & 0.52 & 0.52 & 0.53 \\
\hline Variance: regions & 0.12 & 0.13 & 0.12 & 0.13 & 0.12 \\
\hline Variance: residual & 0.05 & 0.05 & 0.05 & 0.05 & 0.05 \\
\hline
\end{tabular}




\section{A.6 Number of IO Memberships and Democratic Backsliding: Pre- vs. Post-Cold War Eras}

Because international democracy promotion became substantially more prevalent following the end of the Cold War, I also re-estimate the models from Table 4.4 for two different time periods: the Cold War era (1945-1989) and the post-Cold War era (1990-2015). The results of these models, which can be found in Tables A.11 and A.12, suggest that my theory is unsurprisingly a largely post-Cold War phenomenon. None of the coefficients on the main independent variables are statistically significant in the models using data from 1945-1989. Although this is likely in part due to missing

data, ${ }^{36}$ the results are unsurprising given that international democracy promotion did not truly begin until the end of the Cold War. This is reflected in the results for the 1990-2015 models, which are consistent with, and in some cases stronger than, the results reported in Table 4.4 .

\footnotetext{
${ }^{36}$ The maximum number of observations in the $1945-1989$ models is 139.
} 
Table A.11: Number of IO Memberships and Democratic Backsliding: Varying Intercepts by Country and Region, 19451989

\begin{tabular}{lccccc}
\hline & Demo IO & Non-Univ Demo IO & Pol/Econ IO & Demo Pol/Econ IO & Interven IO \\
\hline Num. IO memberships 5 years prior & -0.24 & 0.01 & 0.25 & -0.02 & -0.01 \\
& $(0.19)$ & $(0.25)$ & $(0.15)$ & $(0.23)$ & $(0.13)$ \\
GDP pc (log) & $0.60^{* *}$ & $0.52^{*}$ & $0.48^{*}$ & $0.52^{*}$ & $0.53^{*}$ \\
& $(0.23)$ & $(0.23)$ & $(0.22)$ & $(0.22)$ & $(0.24)$ \\
GDP growth pc & -0.05 & -0.06 & -0.05 & -0.05 & $-0.08^{*}$ \\
& $(0.04)$ & $(0.04)$ & $(0.04)$ & $(0.04)$ & $(0.04)$ \\
DIS index & $-1.98^{* * *}$ & $-1.99^{* * *}$ & $-2.03^{* * *}$ & $-1.99^{* * *}$ & $-2.08^{* * *}$ \\
& $(0.10)$ & $(0.11)$ & $(0.10)$ & $(0.11)$ & $(0.11)$ \\
Effec. num. parties (log) & -0.13 & -0.12 & -0.10 & -0.12 & -0.09 \\
& $(0.08)$ & $(0.08)$ & $(0.08)$ & $(0.08)$ & $(0.08)$ \\
State age (log) & 0.10 & 0.06 & 0.02 & 0.07 & 0.08 \\
& $(0.10)$ & $(0.10)$ & $(0.10)$ & $(0.10)$ & $(0.10)$ \\
Internal conflict & -0.03 & -0.04 & -0.04 & -0.04 & -0.03 \\
& $(0.03)$ & $(0.03)$ & $(0.03)$ & $(0.03)$ & $(0.03)$ \\
Oil income pc & 0.16 & 0.18 & 0.21 & 0.18 & 0.15 \\
& $(0.22)$ & $(0.22)$ & $(0.21)$ & $(0.22)$ & $(0.21)$ \\
Ethnic frac. & -0.04 & -0.02 & -0.02 & -0.02 & -0.03 \\
& $(0.24)$ & $(0.24)$ & $(0.24)$ & $(0.24)$ & $(0.26)$ \\
Mean region DIS change & -0.05 & -0.07 & $-0.10^{*}$ & -0.06 & -0.05 \\
& $(0.04)$ & $(0.04)$ & $(0.04)$ & $(0.04)$ & $(0.03)$ \\
Lagged DV & $-0.07^{* * *}$ & $-0.07^{* *}$ & $-0.06^{* *}$ & $-0.07^{* *}$ & $-0.06^{* *}$ \\
& $(0.02)$ & $(0.02)$ & $(0.02)$ & $(0.02)$ & $(0.02)$ \\
\hline AIC & 121.71 & 122.74 & 121.12 & 122.93 & 100.40 \\
BIC & 165.72 & 166.76 & 165.14 & 166.95 & 141.83 \\
Log. lik. & -45.85 & -46.37 & -45.56 & -46.47 & -35.20 \\
Observations & 139 & 139 & 139 & 139 & 117 \\
Num. countries & 23 & 23 & 23 & 23 & 21 \\
Num. regions & 11 & 11 & 11 & 11 & 11 \\
Variance: countries & 0.85 & 0.87 & 0.89 & 0.87 & 0.83 \\
Variance: regions & 0.15 & 0.13 & 0.17 & 0.14 & 0.20 \\
Variance: residual & 0.04 & 0.04 & 0.04 & 0.04 & 0.04 \\
\hline
\end{tabular}

Note: Dependent variable: 5 -year change in DIS index. ${ }^{* * *} p<0.001,{ }^{* *} p<0.01,{ }^{*} p<0.05$ 
Table A.12: Number of IO Memberships and Democratic Backsliding: Varying Intercepts by Country and Region, 19902015

\begin{tabular}{lccccc}
\hline & Demo IO & Non-Univ Demo IO & Pol/Econ IO & Demo Pol/Econ IO & Interven IO \\
\hline Num. IO memberships 5 years prior & $-0.14^{* * *}$ & $-0.11^{* * *}$ & $-0.25^{* * *}$ & $-0.11^{* * *}$ & $-0.31^{* * *}$ \\
& $(0.03)$ & $(0.02)$ & $(0.05)$ & $(0.02)$ & $(0.06)$ \\
GDP pc (log) & $0.57^{* * *}$ & $0.55^{* * *}$ & $0.58^{* * *}$ & $0.54^{* * *}$ & $0.52^{* * *}$ \\
& $(0.06)$ & $(0.06)$ & $(0.06)$ & $(0.06)$ & $(0.06)$ \\
GDP growth pc & -0.02 & -0.03 & -0.02 & -0.03 & $(0.02$ \\
& $(0.02)$ & $(0.02)$ & $(0.02)$ & $(0.02)$ & $(0.02)$ \\
DIS index & $-1.98^{* * *}$ & $-1.98^{* * *}$ & $-1.98^{* * *}$ & $-1.99^{* * *}$ & $-1.98^{* * *}$ \\
& $(0.03)$ & $(0.03)$ & $(0.03)$ & $(0.03)$ & $(0.03)$ \\
Effec. num. parties (log) & 0.02 & 0.02 & 0.02 & 0.02 & 0.02 \\
& $(0.02)$ & $(0.02)$ & $(0.02)$ & $(0.02)$ & $(0.02)$ \\
State age (log) & 0.01 & 0.01 & 0.01 & 0.01 & 0.00 \\
& $(0.04)$ & $(0.04)$ & $(0.04)$ & $(0.04)$ & $(0.04)$ \\
Internal conflict & 0.00 & 0.00 & 0.01 & 0.01 & 0.01 \\
& $(0.01)$ & $(0.01)$ & $(0.01)$ & $(0.01)$ & $(0.01)$ \\
Oil income pc & $-1.13^{*}$ & $-1.19^{*}$ & $-1.18^{*}$ & $-1.19^{*}$ & $-1.12^{*}$ \\
& $(0.56)$ & $(0.56)$ & $(0.56)$ & $(0.56)$ & $(0.56)$ \\
Ethnic frac. & $-0.25^{*}$ & $-0.25^{*}$ & $-0.26^{*}$ & $-0.26^{*}$ & $-0.33^{* *}$ \\
& $(0.11)$ & $(0.11)$ & $(0.11)$ & $(0.11)$ & $(0.11)$ \\
Mean region DIS change & -0.01 & -0.01 & 0.00 & -0.01 & 0.01 \\
& $(0.02)$ & $(0.02)$ & $(0.02)$ & $(0.02)$ & $(0.02)$ \\
Lagged DV & $-0.03^{* *}$ & $-0.03^{* *}$ & $-0.03^{* *}$ & $-0.02^{*}$ & $-0.03^{* *}$ \\
& $(0.01)$ & $(0.01)$ & $(0.01)$ & $(0.01)$ & $(0.01)$ \\
\hline AIC & 951.78 & 949.59 & 950.92 & 954.59 & 950.28 \\
BIC & 1027.66 & 1025.47 & 1026.80 & 1030.47 & 1026.16 \\
Log. lik. & -460.89 & -459.80 & -460.46 & -462.30 & -460.14 \\
Observations & 1163 & 1163 & 1163 & 1163 & 1163 \\
Num. countries & 69 & 69 & 69 & 69 & 69 \\
Num. regions & 15 & 15 & 15 & 15 & 15 \\
Variance: countries & 0.63 & 0.63 & 0.64 & 0.64 & 0.74 \\
Variance: regions & 0.24 & 0.25 & 0.25 & 0.26 & 0.20 \\
Variance: residual & 0.09 & 0.09 & 0.09 & 0.09 & 0.09 \\
\hline
\end{tabular}

Note: Dependent variable: 5 -year change in DIS index. ${ }^{* * *} p<0.001,{ }^{* *} p<0.01,{ }^{*} p<0.05$ 


\section{A.7 Number of IO Memberships and Democratic Backsliding: Alternative Dependent Variable}

Since my DIS index is a new measure, I re-estimate the models from Table 4.4 using the Liberal Democracy index from the Varieties of Democracy dataset to measure democratic backsliding. This variable measures the extent to which a country constitutionally protects individual and minority rights, exhibits strong rule of law, has an independent judiciary, maintains institutional checks on executive power, and upholds free and fair elections (Coppedge et al., 2018); in other words, it picks up on many, though not all, of the characteristics I include in my definition of democratic backsliding. As such, it is better able to capture subtle differences between democracies than other regime indicators, such as Polity or Freedom House. Using the Liberal Democracy index, I re-create the dependent variable and re-estimate the models from Table 4.4. The results with this alternative operationalization of democratic backsliding are similar to the main results in Table 4.4 and can be found in Table A.13. 
Table A.13: Number of IO Memberships and Democratic Backsliding: Alternative Dependent Variable

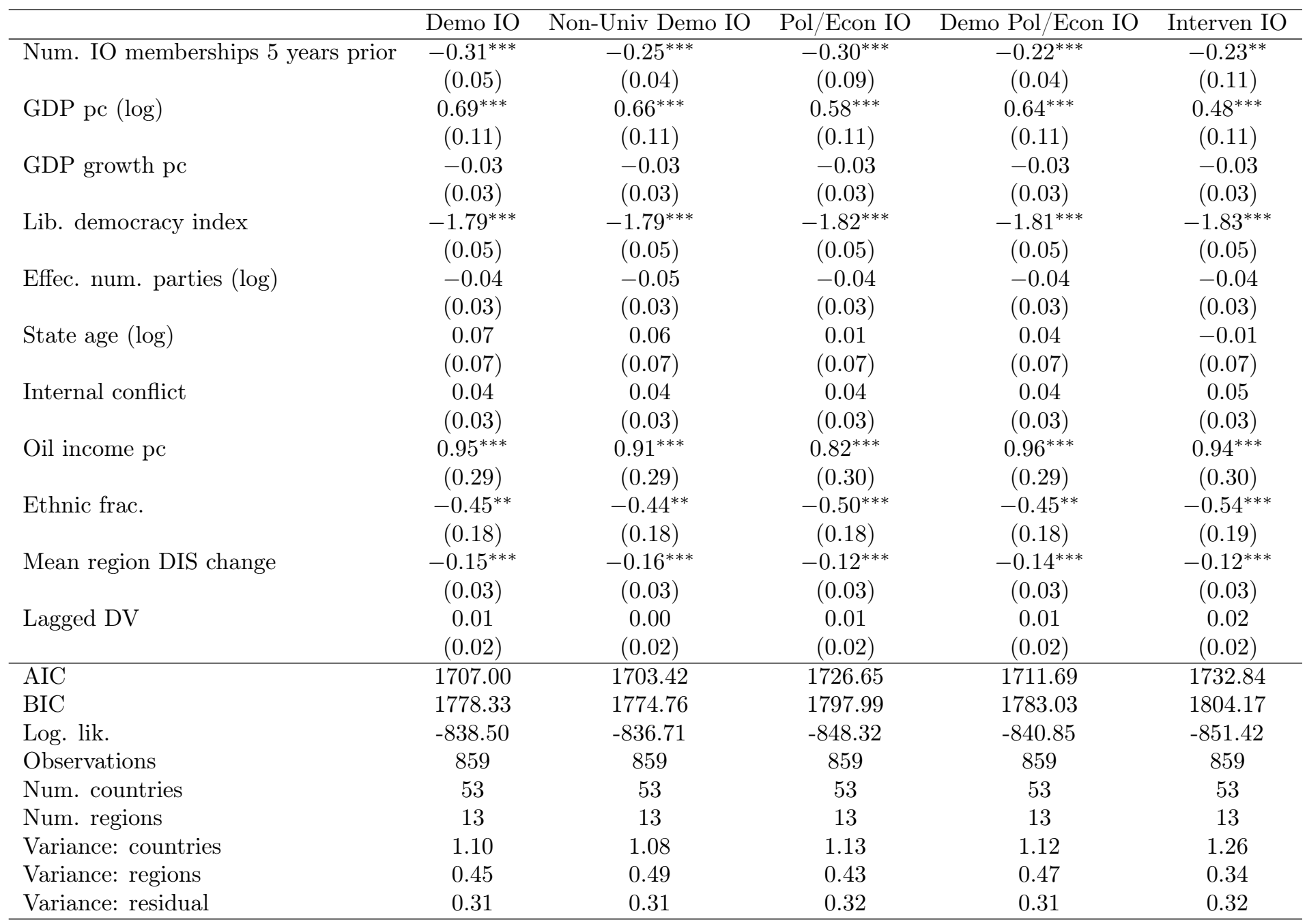

Note: Dependent variable: 5 -year change in Liberal Democracy index. ${ }^{* * *} p<0.001,{ }^{* *} p<0.01,{ }^{*} p<0.05$ 


\section{A.8 Number of IO Memberships and Democratic Backsliding: Two-Stage Selection Models}

Since not all new democracies are equally likely to join certain types of international organizations, there may be a selection problem in the data. To verify that selection bias is not driving the main results, I estimate a two-step Heckman selection model (Heckman, 1979). The first stage models the selection process by using a probit model to estimate a state's probability of joining different types of IOs. Following Poast and Urpelainen, the selection models include indicators for four continents, the Americas, Asia, Europe, and Oceania, with Africa as the omitted category; these indicators are interacted with year (scaled) to model regional trends in IO membership over time (Poast and Urpelainen, 2015). I also include an indicator for whether a state is in its first five years as a democracy since research shows that new democracies are particularly likely to join IOs (Mansfield and Pevehouse, 2008).

The second stage outcome models draw on Table 4.4 and estimate the relationship between IO memberships and a state's subsequent democratic trajectory; these models include the Mill's ratio, calculated using the predicted probabilities from the first stage selection models, as a control variable. The results of the first stage selection models can be found in Table A.14, and the outcome models controlling for selection and with robust standard errors can be found in Table A.15.

Controlling for potential selection effects, I still find evidence that membership in IOs is linked to subsequent democratic backsliding being more likely in new democracies. 
Table A.14: Selection Models (First Stage)

\begin{tabular}{|c|c|c|c|c|c|}
\hline & Demo IO & Non-Univ Demo IO & Pol/Econ IO & Demo Pol/Econ IO & Interven IO \\
\hline First 5 years as democracy & 0.11 & 0.11 & 0.11 & 0.11 & 0.11 \\
\hline & $(0.11)$ & $(0.11)$ & $(0.11)$ & $(0.11)$ & $(0.11)$ \\
\hline Americas & 0.21 & 0.21 & 0.21 & 0.21 & 0.21 \\
\hline & $(0.15)$ & $(0.15)$ & $(0.15)$ & $(0.15)$ & $(0.15)$ \\
\hline Asia & $-0.57^{* * *}$ & $-0.57^{* * *}$ & $-0.57^{* * *}$ & $-0.57^{* * *}$ & $-0.57^{* * *}$ \\
\hline & $(0.19)$ & $(0.19)$ & $(0.19)$ & $(0.19)$ & $(0.19)$ \\
\hline Europe & $0.29^{*}$ & $0.29^{*}$ & $0.29^{*}$ & $0.29^{*}$ & $0.29^{*}$ \\
\hline & $(0.16)$ & $(0.16)$ & $(0.16)$ & $(0.16)$ & $(0.16)$ \\
\hline Oceania & -0.07 & -0.07 & -0.07 & -0.07 & -0.07 \\
\hline & $(0.65)$ & $(0.65)$ & $(0.65)$ & $(0.65)$ & $(0.65)$ \\
\hline Year & -0.18 & -0.18 & -0.18 & -0.18 & -0.18 \\
\hline ن & $(0.14)$ & $(0.14)$ & $(0.14)$ & $(0.14)$ & $(0.14)$ \\
\hline Americas year & 0.23 & 0.23 & 0.23 & 0.23 & 0.23 \\
\hline & $(0.17)$ & $(0.17)$ & $(0.17)$ & $(0.17)$ & $(0.17)$ \\
\hline Asia year & 0.33 & 0.33 & 0.33 & 0.33 & 0.33 \\
\hline & $(0.21)$ & $(0.21)$ & $(0.21)$ & $(0.21)$ & $(0.21)$ \\
\hline Europe year & 0.08 & 0.08 & 0.08 & 0.08 & 0.08 \\
\hline & $(0.19)$ & $(0.19)$ & $(0.19)$ & $(0.19)$ & $(0.19)$ \\
\hline Oceania year & 1.43 & 1.43 & 1.43 & 1.43 & 1.43 \\
\hline & $(1.06)$ & $(1.06)$ & $(1.06)$ & $(1.06)$ & $(1.06)$ \\
\hline $\mathrm{R}^{2}$ & 0.78 & 0.78 & 0.75 & 0.77 & 0.78 \\
\hline Adjusted $\mathrm{R}^{2}$ & 0.76 & 0.76 & 0.73 & 0.75 & 0.76 \\
\hline Observations & 1383 & 1383 & 1383 & 1383 & 1383 \\
\hline Censored & 1215 & 1215 & 1215 & 1215 & 1215 \\
\hline Observed & 168 & 168 & 168 & 168 & 168 \\
\hline
\end{tabular}


Table A.15: Number of IO Memberships and Democratic Backsliding with Selection Correction and Robust Standard Errors (Second Stage)

\begin{tabular}{lccccc}
\hline & Demo IO & Non-Univ Demo IO & Pol/Econ IO & Demo Pol/Econ IO & Interven IO \\
\hline Num. IO memberships 5 years prior & $-0.49^{* * *}$ & $-0.36^{* * *}$ & -0.09 & $-0.35^{* * *}$ & $-0.69^{* * *}$ \\
& $(0.11)$ & $(0.07)$ & $(0.12)$ & $(0.09)$ & $(0.15)$ \\
GDP pc (log) & $0.80^{* * *}$ & $0.79^{* * *}$ & $0.80^{* * *}$ & $0.78^{* * *}$ & $0.93^{* * *}$ \\
& $(0.09)$ & $(0.09)$ & $(0.09)$ & $(0.09)$ & $(0.09)$ \\
GDP growth pc & -0.05 & -0.04 & -0.08 & -0.06 & -0.10 \\
DIS index & $(0.08)$ & $(0.08)$ & $(0.09)$ & $(0.08)$ & $(0.08)$ \\
& $-1.28^{* * *}$ & $-1.30^{* * *}$ & $-1.39^{* * *}$ & $-1.31^{* * *}$ & $-1.30^{* * *}$ \\
Effec. num. parties (log) & $(0.09)$ & $(0.09)$ & $(0.09)$ & $(0.09)$ & $(0.08)$ \\
State age (log) & 0.10 & 0.10 & 0.04 & 0.09 & 0.10 \\
& $(0.06)$ & $(0.06)$ & $(0.07)$ & $(0.07)$ & $(0.06)$ \\
Internal conflict & -0.07 & -0.08 & -0.04 & -0.08 & 0.08 \\
& $(0.07)$ & $(0.07)$ & $(0.08)$ & $(0.08)$ & $(0.08)$ \\
Oil income pc & -0.02 & -0.02 & -0.00 & -0.03 & 0.01 \\
& $(0.04)$ & $(0.04)$ & $(0.04)$ & $(0.04)$ & $(0.04)$ \\
Ethnic frac. & $-9.09^{* * *}$ & $-9.30^{* * *}$ & $-9.30^{* * *}$ & $-8.94^{* * *}$ & $-9.35^{* * *}$ \\
& $(1.66)$ & $(1.65)$ & $(1.79)$ & $(1.70)$ & $(1.64)$ \\
Mean region DIS change & $0.22^{* * *}$ & $0.20^{* * *}$ & $0.21^{* * *}$ & $0.21^{* * *}$ & $0.27^{* * *}$ \\
& $(0.05)$ & $(0.05)$ & $(0.05)$ & $(0.05)$ & $(0.05)$ \\
Lagged DV & $0.13^{* * *}$ & $0.10^{* *}$ & $0.21^{* * *}$ & $0.14^{* * *}$ & $0.18^{* * *}$ \\
& $(0.05)$ & $(0.05)$ & $(0.04)$ & $(0.05)$ & $(0.04)$ \\
Mills ratio & $-0.09^{* * *}$ & $-0.10^{* * *}$ & -0.04 & $-0.08^{* *}$ & $-0.09^{* *}$ \\
Sigma & $(0.04)$ & $(0.04)$ & $(0.04)$ & $(0.04)$ & $(0.03)$ \\
& -0.49 & $-0.59^{*}$ & -0.08 & -0.53 & -0.27 \\
Rho & $(0.35)$ & $(0.35)$ & $(0.36)$ & $(0.37)$ & $(0.33)$ \\
& 0.71 & 0.77 & 0.60 & 0.75 & 0.61
\end{tabular}

Note: Robust standard errors in parentheses. ${ }^{* * *} p<0.01,{ }^{* *} p<0.05,{ }^{*} p<0.1$ 


\section{A.9 Number of IO Memberships and Democratic Backsliding: Democracies and Anocracies}

By focusing exclusively on fully democratic states in the main models, I may be creating another sort of selection bias in the data. Therefore, I re-estimate the models from Table 4.4 with data including both developing democracies and anocracies,

defined as any country-year with a Polity score greater than -5 . The results of these models are similar to those reported in Table 4.4 and can be found in Table A.16. 
Table A.16: Number of IO Memberships and Democratic Backsliding: Democracies and Anocracies

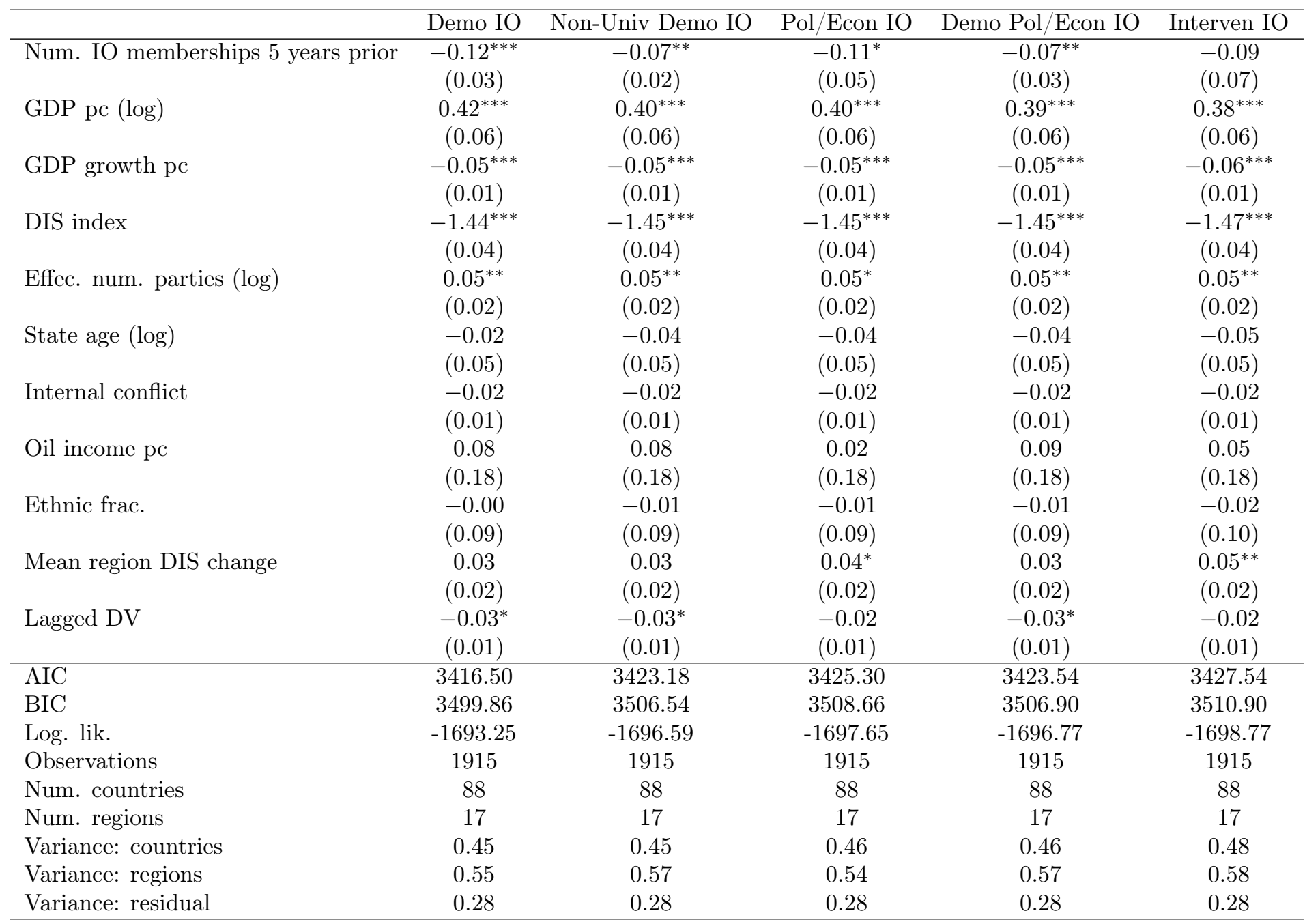

Note: Dependent variable: 5 -year change in DIS index. ${ }^{* * *} p<0.001,{ }^{* *} p<0.01,{ }^{*} p<0.05$ 


\section{A.10 Number of IO Memberships and Democratic Backslid- ing: No European Union}

The European Union (EU) is arguably the IO most commonly associated with

democracy promotion and the organization most likely to both increase executive power and to constrain its member states' domestic policy space. This raises the concern that EU membership is largely driving the results in Table 4.4. Although this is less likely since the main models include varying intercepts for region, I nevertheless re-estimate the models from Table 4.4, excluding the EU membership altogether from the analysis. These models can be found in Table A.17. The results from Table 4.4 hold even when the EU is removed from the data. 
Table A.17: Number of IO Memberships and Democratic Backsliding: No European Union

\begin{tabular}{|c|c|c|c|c|c|}
\hline & Demo IO & Non-Univ Demo IO & Pol/Econ IO & Demo Pol/Econ IO & Interven IO \\
\hline Num. IO memberships 5 years prior & $\begin{array}{c}-0.17^{* * *} \\
(0.03)\end{array}$ & $\begin{array}{c}-0.12^{* * *} \\
(0.02)\end{array}$ & $\begin{array}{c}-0.20^{* * *} \\
(0.04)\end{array}$ & $\begin{array}{c}-0.12^{* * *} \\
(0.02)\end{array}$ & $\begin{array}{c}-0.26^{* * *} \\
(0.06)\end{array}$ \\
\hline GDP pc (log) & $0.56^{* * *}$ & $0.54^{* * *}$ & $0.53^{* * *}$ & $0.52^{* * *}$ & $0.49^{* * *}$ \\
\hline & $(0.05)$ & $(0.05)$ & $(0.05)$ & $(0.05)$ & $(0.05)$ \\
\hline GDP growth pc & 0.00 & -0.00 & -0.00 & -0.00 & -0.00 \\
\hline & $(0.01)$ & $(0.01)$ & $(0.01)$ & $(0.01)$ & $(0.01)$ \\
\hline DIS index & $-1.94^{* * *}$ & $-1.94^{* * *}$ & $-1.94^{* * *}$ & $-1.94^{* * *}$ & $-1.94^{* * *}$ \\
\hline & $(0.03)$ & $(0.03)$ & $(0.03)$ & $(0.03)$ & $(0.03)$ \\
\hline Effec. num. parties (log) & 0.01 & 0.01 & 0.01 & 0.01 & 0.01 \\
\hline & $(0.02)$ & $(0.02)$ & $(0.02)$ & $(0.02)$ & $(0.02)$ \\
\hline State age $(\log )$ & 0.00 & -0.01 & -0.01 & -0.00 & -0.01 \\
\hline & $(0.03)$ & $(0.03)$ & $(0.03)$ & $(0.03)$ & $(0.03)$ \\
\hline Internal conflict & -0.00 & -0.00 & 0.00 & -0.00 & 0.01 \\
\hline & $(0.01)$ & $(0.01)$ & $(0.01)$ & $(0.01)$ & $(0.01)$ \\
\hline Oil income pc & $0.94^{* * *}$ & $0.93^{* * *}$ & $0.82^{* * *}$ & $0.95^{* * *}$ & $0.82^{* * *}$ \\
\hline & $(0.16)$ & $(0.16)$ & $(0.17)$ & $(0.16)$ & $(0.17)$ \\
\hline Ethnic frac. & $-0.29^{* * *}$ & $-0.28^{* * *}$ & $-0.31^{* * *}$ & $-0.30^{* * *}$ & $-0.33^{* * *}$ \\
\hline & $(0.11)$ & $(0.11)$ & $(0.11)$ & $(0.11)$ & $(0.11)$ \\
\hline Mean region DIS change & -0.02 & -0.02 & -0.01 & -0.02 & -0.00 \\
\hline & $(0.01)$ & $(0.01)$ & $(0.01)$ & $(0.01)$ & $(0.01)$ \\
\hline Lagged DV & $-0.03^{* * *}$ & $-0.04^{* * *}$ & $-0.04^{* * *}$ & $-0.03^{* * *}$ & $-0.04^{* * *}$ \\
\hline & $(0.01)$ & $(0.01)$ & $(0.01)$ & $(0.01)$ & $(0.01)$ \\
\hline AIC & 1102.84 & 1104.18 & 1117.61 & 1111.49 & 1117.20 \\
\hline $\mathrm{BIC}$ & 1180.41 & 1181.76 & 1195.19 & 1189.06 & 1194.78 \\
\hline Log. lik. & -536.42 & -537.09 & -543.81 & -540.74 & -543.60 \\
\hline Observations & 1302 & 1302 & 1302 & 1302 & 1302 \\
\hline Num. countries & 70 & 70 & 70 & 70 & 70 \\
\hline Num. regions & 15 & 15 & 15 & 15 & 15 \\
\hline Variance: countries & 0.70 & 0.70 & 0.72 & 0.71 & 0.77 \\
\hline Variance: regions & 0.25 & 0.26 & 0.24 & 0.27 & 0.20 \\
\hline Variance: residual & 0.10 & 0.10 & 0.10 & 0.10 & 0.10 \\
\hline
\end{tabular}

Note: Dependent variable: 5 -year change in DIS index. ${ }^{* * *} p<0.001,{ }^{* *} p<0.01,{ }^{*} p<0.05$ 


\section{A.11 Number of IO Memberships and Democratic Backslid- ing: Placebo Tests}

The results reported in Table 4.4 may simply be due to a spurious correlation between IO membership and democratic trajectories. If my theory is correct, in addition to a negative and significant relationship between IO membership and democratic changes, there should also be no relationship between membership in other types of IOs that are not linked to democratic outcomes and democratic trajectories in their member states. Therefore, I estimate several placebo models.

Specifically, first I re-estimate the same models from Table 4.4 but with main independent variables that count the number of non-democratically committed, nonpolitical or non-economic, ${ }^{37}$ and minimalist (as opposed to interventionist) IOs a state was a member of 5 years prior. The results of these models, which can be found in Table A.18, return mixed results. The first two models, which capture membership in non-democratic and non-political and non-economic IOs, still find a negative and significant relationship between increased membership in these irrelevant IOs and subsequent backsliding. However, as expected, the third model finds no significant relationship between membership in minimalist IOs and democratic trajectories.

One reason for these unexpected results, and for why these IOs that are theoretically irrelevant to democracy promotion appear to impact democratic trajectories, may be because membership in these IOs is serving as a proxy for other international factors that impact domestic regime outcomes. By not explicitly controlling for these other international-level factors, the models from Table A.18 may be attributing more influence to these irrelevant IOs than they have in practice. Therefore, I re-estimate

${ }^{37}$ This includes "technical" and "other" IOs, such as those focused on aviation, statistics, sanitation and health, or research (Poast and Urpelainen, 2015). 
these placebo models to also include the globalization controls used in the international models in Appendix A.3: foreign direct investment, trade openness, and a Cold War era indicator; these additional models are the same as those from Table A.4 except the independent variables are membership counts in non-democratic, non-political or non-economic, and minimalist IOs. The results of these models, which can be found in Table A.19, suggest additional support for the theory: once these other international-level factors are included in the model, there is no significant relationship between membership in irrelevant IOs and democratic trajectories in new democracies. 
Table A.18: Number of IO Memberships and Democratic Backsliding: Placebo

\begin{tabular}{lccc}
\hline & Non-Demo IO & Non-Pol/Econ IO & Minimalist IO \\
\hline Num. IO memberships 5 years prior & $-0.18^{* * *}$ & $-0.13^{* * *}$ & -0.06 \\
& $(0.04)$ & $(0.04)$ & $(0.04)$ \\
GDP pc $(\log )$ & $0.49^{* * *}$ & $0.46^{* * *}$ & $0.42^{* * *}$ \\
& $(0.05)$ & $(0.05)$ & $(0.05)$ \\
GDP growth pc & $-0.04^{* *}$ & $-0.04^{* *}$ & $-0.04^{* * *}$ \\
& $(0.01)$ & $(0.01)$ & $(0.01)$ \\
DIS index & $-2.26^{* * *}$ & $-2.27^{* * *}$ & $-2.29^{* * *}$ \\
& $(0.03)$ & $(0.03)$ & $(0.03)$ \\
Effec. num. parties $(\log )$ & 0.01 & 0.01 & 0.01 \\
& $(0.02)$ & $(0.02)$ & $(0.02)$ \\
State age $(\log )$ & -0.01 & -0.01 & -0.02 \\
& $(0.03)$ & $(0.04)$ & $(0.04)$ \\
Internal conflict & 0.01 & 0.01 & 0.01 \\
& $(0.01)$ & $(0.01)$ & $(0.01)$ \\
Oil income pc & $0.80^{* * *}$ & $0.88^{* * *}$ & $0.93^{* * *}$ \\
& $(0.17)$ & $(0.17)$ & $(0.18)$ \\
Ethnic frac. & $-0.34^{* * *}$ & $-0.36^{* * *}$ & $-0.35^{* * *}$ \\
& $(0.11)$ & $(0.11)$ & $(0.11)$ \\
Mean region DIS change & 0.00 & 0.00 & 0.01 \\
& $(0.01)$ & $(0.01)$ & $(0.01)$ \\
Lagged DV & $-0.03^{* * *}$ & $-0.03^{* * *}$ & $-0.03^{* * *}$ \\
& $(0.01)$ & $(0.01)$ & $(0.01)$ \\
\hline AIC & 1123.25 & 1129.83 & 1136.91 \\
BIC & 1200.83 & 1207.40 & 1214.48 \\
Log. lik. & -546.63 & -549.91 & -553.45 \\
Observations & 1302 & 1302 & 1302 \\
Num. countries & 70 & 70 & 70 \\
Num. regions & 15 & 15 & 15 \\
Variance: countries & 0.78 & 0.80 & 0.80 \\
Variance: regions & 0.20 & 0.20 & 0.22 \\
Variance: residual & 0.10 & 0.10 & 0.10 \\
\hline Note: Dependent variable: 5-year change in DIS index $* * * *<0.001)^{* * *}<0.01, * p<0.05$ &
\end{tabular}


Table A.19: Number of IO Memberships and Democratic Backsliding: International Factors, Placebo

\begin{tabular}{|c|c|c|c|}
\hline & Non-Demo IO & Non-Pol/Econ IO & Minimalist IO \\
\hline Num. IO memberships 5 years prior & $\begin{array}{l}-0.07 \\
(0.05)\end{array}$ & $\begin{array}{l}-0.01 \\
(0.05)\end{array}$ & $\begin{array}{c}0.04 \\
(0.05)\end{array}$ \\
\hline GDP pc (log) & $\begin{array}{c}0.42^{* * *} \\
(0.05)\end{array}$ & $\begin{array}{c}0.39^{* * *} \\
(0.05)\end{array}$ & $\begin{array}{c}0.38^{* * *} \\
(0.05)\end{array}$ \\
\hline GDP growth pc & $\begin{array}{c}-0.03^{*} \\
(0.02)\end{array}$ & $\begin{array}{c}-0.03^{*} \\
(0.02)\end{array}$ & $\begin{array}{c}-0.03^{*} \\
(0.02)\end{array}$ \\
\hline DIS index & $\begin{array}{c}-2.26^{* * *} \\
(0.04)\end{array}$ & $\begin{array}{c}-2.27^{* * *} \\
(0.04)\end{array}$ & $\begin{array}{c}-2.28^{* * *} \\
(0.04)\end{array}$ \\
\hline Effec. num. parties (log) & $\begin{array}{c}0.02 \\
(0.02)\end{array}$ & $\begin{array}{c}0.02 \\
(0.02)\end{array}$ & $\begin{array}{c}0.02 \\
(0.02)\end{array}$ \\
\hline State age $(\log )$ & $\begin{array}{l}-0.03 \\
(0.04)\end{array}$ & $\begin{array}{l}-0.04 \\
(0.04)\end{array}$ & $\begin{array}{l}-0.05 \\
(0.04)\end{array}$ \\
\hline Internal conflict & $\begin{array}{l}-0.01 \\
(0.01)\end{array}$ & $\begin{array}{l}-0.01 \\
(0.01)\end{array}$ & $\begin{array}{l}-0.01 \\
(0.01)\end{array}$ \\
\hline Oil income pc & $\begin{array}{c}0.93^{* * *} \\
(0.17)\end{array}$ & $\begin{array}{c}0.99^{* * *} \\
(0.17)\end{array}$ & $\begin{array}{c}1.04^{* * *} \\
(0.17)\end{array}$ \\
\hline Ethnic frac. & $\begin{array}{c}-0.27^{* *} \\
(0.11)\end{array}$ & $\begin{array}{c}-0.27^{* *} \\
(0.11)\end{array}$ & $\begin{array}{c}-0.27^{* *} \\
(0.11)\end{array}$ \\
\hline FDI inflow & $\begin{array}{c}0.00 \\
(0.02)\end{array}$ & $\begin{array}{c}0.00 \\
(0.02)\end{array}$ & $\begin{array}{c}0.00 \\
(0.02)\end{array}$ \\
\hline Trade openness & $\begin{array}{c}0.01 \\
(0.01)\end{array}$ & $\begin{array}{c}0.01 \\
(0.01)\end{array}$ & $\begin{array}{c}0.01 \\
(0.01)\end{array}$ \\
\hline Post Cold War & $\begin{array}{c}-0.11^{* * *} \\
(0.03)\end{array}$ & $\begin{array}{c}-0.11^{* * *} \\
(0.03)\end{array}$ & $\begin{array}{c}-0.12^{* * *} \\
(0.03)\end{array}$ \\
\hline Mean region DIS change & $\begin{array}{l}-0.01 \\
(0.02)\end{array}$ & $\begin{array}{l}-0.02 \\
(0.02)\end{array}$ & $\begin{array}{l}-0.02 \\
(0.02)\end{array}$ \\
\hline Lagged DV & $\begin{array}{c}-0.03^{* * *} \\
(0.01)\end{array}$ & $\begin{array}{c}-0.03^{* * *} \\
(0.01)\end{array}$ & $\begin{array}{c}-0.02^{* * *} \\
(0.01)\end{array}$ \\
\hline AIC & 1027.75 & 1029.80 & 1028.94 \\
\hline $\mathrm{BIC}$ & 1119.86 & 1121.91 & 1121.05 \\
\hline Log. lik. & -495.87 & -496.90 & -496.47 \\
\hline Observations & 1233 & 1233 & 1233 \\
\hline Num. countries & 69 & 69 & 69 \\
\hline Num. regions & 15 & 15 & 15 \\
\hline Variance: countries & 0.77 & 0.77 & 0.77 \\
\hline Variance: regions & 0.21 & 0.22 & 0.24 \\
\hline Variance: residual & 0.09 & 0.09 & 0.09 \\
\hline
\end{tabular}

